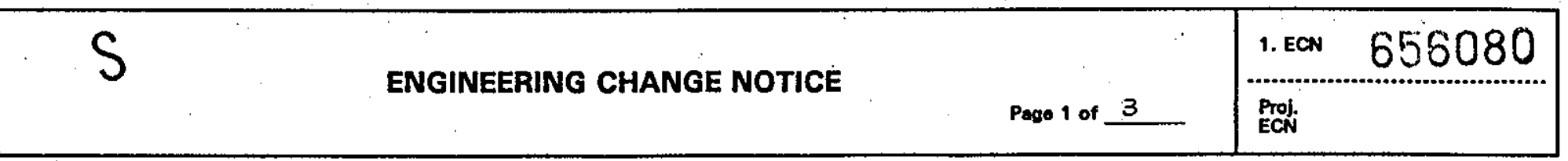

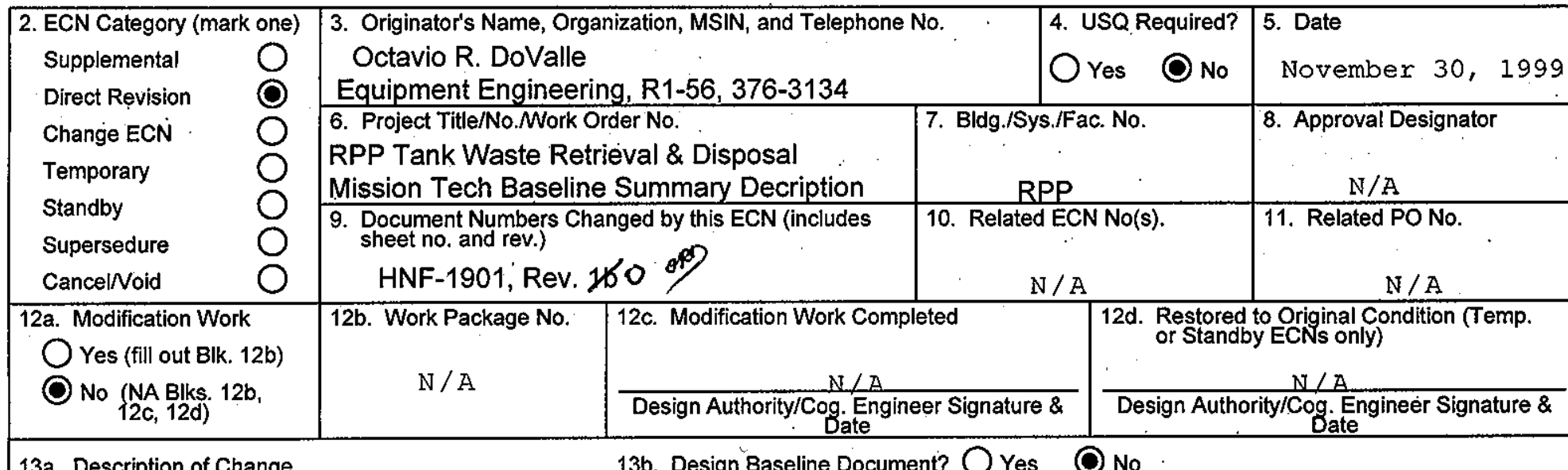

13a. Description of Change 13b. Design Baseline Document? $\bigcirc$ Yes

This is a periodic updated/revision to the subject document.

This document provides a summary of the tecthical baseline for the Tank Waste Retrieval and Disposal (TWR\&D)mission, and a major element of the River Protection Project (RPP).

Technical baseline documents serve as inputs to, or are products of, work scope activities.

Maintaining this summary description document includes the following:

* Reviewing new and revised technical baseline documents.

* Assigning document categories (e.g., configuration information, requirement, source document) and identifying the source information for each document.

* Preparing technical baseline document summaries for inclusion in the appendices of this summary description document. This document contains eight appendices $(A-H)$. A through $F$ support ares described in sections $2.0-9.0$. The summary information for each document is included in the corresponding appendix:

Assigned document number and title, Configuration management (i.e. maintained current or not), Responsible organization, Status of preparation/revision, Source information (i.e., the specific information that resides in the document designated to represent element(s) of the technical baseline, and interrelated documents.

Appendix $\mathrm{G}$ provides complete citations for the references used in this summary description document.

Appendix $\mathrm{H}$ provides the crosswalk between guidance/requirements and the deliverables.

14a. Justification (mark one)
Criteria Change
Design Improvement
Environmental
Facility Deactivation
As-Found
Facilitate Const.
Const. Error/Omission
Design Error/Omission

15. Distribution (include name, MSIN, and no. of copies)

SEE ATTACHED DISTRIBUTION LIST

$$
\text { page } 3 .
$$

14b. Justification Details

O

UPDATE/REVISION OF SUBJECT DOCUMENT (HNF-1901)

The subject document contains summary information for each technical document and shall be updated as new information becomes available. It also should reflect the most current plans, consistent with the retrieval and disposal mission. 
ENGINEERING CHANGE NOTICE

16. Design Verification Required

OYes

O No
17. Cost Impact

ENGINEERING

Additional $\bigcirc \$ \frac{N}{N} / \mathrm{A}$
Savings $\bigcirc \$ \frac{N}{N} / \mathrm{A}$
Page 2 of 3

CONSTRUCTION

Additional $\bigcirc \$ \ldots$ N/A

Savings $\bigcirc \$$

$N / A$
1. ECN (use no. from pg. 1)

656080

18. Schedule Impact (days)

Improvement

O $N / A$

Delay

O N/A

19. Change Impact Review: Indicate the related documents (other than the engineering documents identified on Side 1) that will be affected by the change described in Block 13. Enter the affected document number in Block 20.

$\begin{array}{lll}\text { SDD/DD } & \text { Seismic/Stress Analysis } \\ \text { Functional Design Criteria } & \square & \text { Stress/Design Report } \\ \text { Operating Specification } & \square & \text { Interface Control Drawing } \\ \text { Criticality Specification } & \square & \text { Calibration Procedure } \\ \text { Conceptual Design Report } & \square & \text { Installation Procedure } \\ \text { Equipment Spec. } & \square & \text { Maintenance Procedure } \\ \text { Const. Spec. } & \square & \text { Engineering Procedure } \\ \text { Procurement Spec. } & \square & \text { Operating Instruction } \\ \text { Vendor Information } & \square & \text { Operating Procedure } \\ \text { OM Manual } & \square & \text { Operational Safety Requirement } \\ \text { FSAR/SAR } & \square & \text { IEFD Drawing } \\ \text { Safety Equipment List } & \square & \text { Cell Arrangement Drawing } \\ \text { Radiation Work Permit } & \square & \text { Essential Material Specification } \\ \text { Environmental Impact Statement } & \square \\ \text { Environmental Report } & \square & \text { Fac. Proc. Samp. Schedule } \\ \text { Environmental Permit } & \square & \text { Inspection Plan }\end{array}$

Tank Calibration Manual

Health Physics Procedure

Spares Multiple Unit Listing

Test Procedures/Specification

Component Index

ASME Coded Item

Human Factor Consideration

Computer Software

Electric Circuit Schedule

ICRS Procedure

Process Control Manual/Plan

Process Flow Chart

Purchase Requisition

Tickler File

None

20. Other Affected Documents: (NOTE: Documents listed below will not be revised by this ECN.) Signatures below indicate that the signing organization thas been notified of other affected documents listed below.

Document Number/Revision

Document Number/Revision

Document Number/Revision

None. The affected document is

identified under "Description of

Change".

21. Approvals

Signature

Date

Design Authority

cog. Eng. O. R. Dovalle Octumi tolbele

Cog. Mgr. A.H.Friberg NAtishere

QA

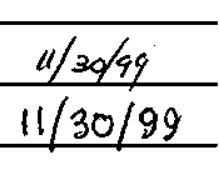

Safety

Environ. N/A

Other

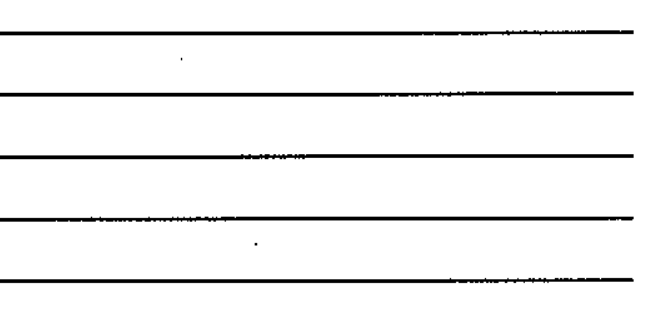

Signature

Date

Design Agent

PE

QA

Safety

Design

Environ.

Other

\section{DEPARTMENT OF ENERGY}

Signature or a Control Number that tracks the Approval Signature

ADDITIONAL 


\begin{tabular}{|c|c|c|}
\hline & & \begin{tabular}{|ll} 
ECN $\quad 656080$
\end{tabular} \\
\hline RING C & Page 3 of 3 & Date November 30,1999 \\
\hline
\end{tabular}

DISTRIBUTUION LIST: (ONE COPY PER ADDRESSEE)

J. N. Appel

R. B. Calmus

A. B. Carlson

O. R. Dovalie

J. R. Freeman-Pollard

A. H. Friberg

O. A. Halverson

S. A. Janicek

R. S. Popielarczyk

S. E. Seeman

R. D. Wojtasek
H $6-64$
S $4-45$
H $3-73$
R $1-56$
R2-89
R $1-56$
R $1-04$
G $3-36$
R2-58
H. 7-06
R2-53 


\section{River Protection Project Tank Waste Retrieval and Disposal Mission Technical Baseline Summary Description}

O. R. DOVALIE

Lockheed Martin Hanford Corp.

Richland, WA 99352

$99 R<-14047$

U.S. Department of Energy Contract DE-AC06-06Rt43200

$\begin{array}{llll}\text { EDT/ECN: } & 656080 & \text { UC: } 2030 & \\ \text { Org Code: } & 74700 & \text { Charge Code: } & 108521 \\ \text { B\&R Code: } & \text { Ew3130010 } & \text { Total Pages: } & 244\end{array}$

Key Words: Periodic Update/Revision of the document titled above

Abstract: This document is one of the several documents prepared by Lockheed Martin Hanford Corp. to support the U. S. Department of Energy's Tank Waste Retrieval and Disposal mission at Hanford. The Tank Waste Retrieval and Disposal mission includes the programs necessary to support tank waste retrieval; waste feed, delivery, storage, and disposal of immobilized waste; and closure of the tank farms.

TRADEMARK DISCLAMMER. Reference herein to any specific commercial product, process, or service by trade name, trademark, manufacturer, or otherwise, does not necessarily constitute or imply its endorsement, recommendation, or favoring by the United States Government or any agency thereof or its contractors or subcontractors.

Printed in the United States of America. To obtain copies of this document, contact: Document Control Services, P.O. Box 950, Mailstop H6-08, Richland WA 99352, Phone (509) 372-2420; Fax (509) 376-4989.

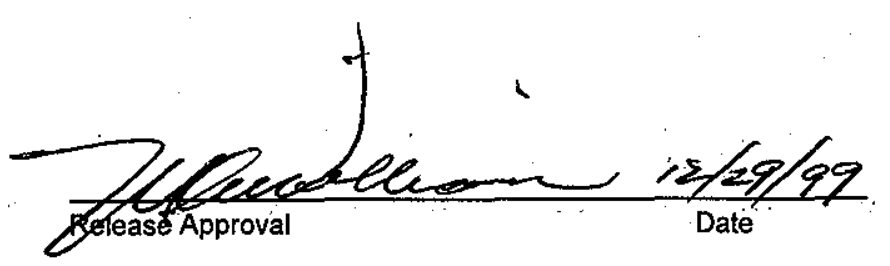

Approved For Public Release 
RECORD OF REVISION

\section{(1) Document Number}

HNF-1901 Rev. 1
Page 1

(2) Title

River Protection Project Tank Waste Retrieval and Disposal Mission Technical Baseline Summary Description

Change Control Record

\begin{tabular}{l|l} 
(3) Revision & (4) Description of Change - Replace, Add, and Delete Pages
\end{tabular} (7)

1 RS Periodic update/revision to the subject document ECN -656080
Authorized for Release

\begin{tabular}{l|l} 
(5) Cog. Engr. & (6) Cog. Mgr. Date
\end{tabular} Ofamito 12/19/99 NA 1 iber 12/14/99 thanidocher 
HNF-1901

$\backsim$

\section{River Protection Project Tank Waste Retrieval and Disposal Mission Technical Baseline Summary Description}

Prepared for the U.S. Department of Energy Assistant Secretary for Environmental Management

LOCKHEE D martan Richland, Washington 
LEGAL DISCLAIMER

This report was prepared as an account of work sponsored by an agency of the United States Government. Neither the United States Government nor any agency thereof, nor any of their employees, nor any of their contractors, subcontractors or their employees, makes any warranty, express or implied, or assumes any legal liability or responsibility for the accuracy, completeness, or any third party's use or the results of such use of any information, apparatus, product, or process disclosed, or represents that its use would not infringe privately owned rights. Reference herein to any specific commercial product, process, or service by trade name, trademark, manufacturer, or otherwise, does not necessarily constitute or imply its endorsement, recommendation, or favoring by the United States Government or any agency thereof or its contractors or subcontractors. The views and opinions of authors expressed herein do not necessarily state or reflect those of the United States Government or any agency thereof.

This report has been reproduced from the best available copy.

Available in paper copy and microfiche.

Available electronically at http://www.doe.gov/bridge. Available for a processing fee to the U.S. Department of Energy and its contractors, in paper, from:

U.S. Department of Energy

Office of Scientific and Technical Information

P.O. Box 62

Oak Ridge, TN 37831-0062

phone: $865-576-8401$

fax: $865-576-5728$

email: reports@adonis.osti.gov(423) 576-8401

Available for sale to the public, in paper, from:

U.S. Department of Commerce

National Technical Information Service

5285 Port Royal Road

Springfield, VA 22161

Phone: 800-553-6847

fax: 703-605-6900

email: orders@ntis.fedworld.gov

online ordering:

http://www.ntis.gov/ordering.htm 


\title{
River Protection Project \\ Tank Waste Retrieval and Disposal Mission Technical Baseline Summary Description
}

\author{
A. H. Friberg \\ J. N. Appel \\ K. C. Burgard \\ R. B. Calmus \\ O. R. DoValle \\ S. E. Seeman \\ Lockheed Martin Hanford Corporation \\ J. R. Freeman-Pollard \\ COGEMA Engineering Corporation
}

\author{
A. B. Carlson \\ Numatec Hanford Corporation
}

Date Published

December 1999

Prepared for the U.S. Department of Energy Assistant Secretary for Environmental Management

LOCKNEED MARTIN

P. O. Box 1500

Richland, Washington

Contractor for the U.S. Department of Energy

Office of River Protection under Contract DE-ACO6-99RL14047

Approved for Public Release; Further Dissemination Unlimited 


\section{HNF-1901 Rev 1}

This page intentionally left blank. 
HNF-1901 Rev 1

Document Title: River Protection Project Retrieval and Disposal Mission Technical Baseline Summary Description

Approved by:

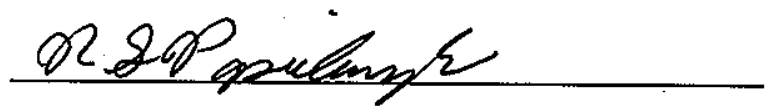

R. S. Popielarczyk, Chief Engineer Lockheed Martin Hanford Corporation
$12-13-99$

Date 
HNF-1901 Rev 1

This page intentionally left blank. 
HNF-1901 Rev 1

\section{EXECUTIVE SUMMARY}

This document, the River Protection Project Retrieval and Disposal Mission Technical Baseline Summary Description, is one of several documents prepared by Lockheed Martin Hanford Corporation to support the U.S. Department of Energy's Tank Waste Retrieval and Disposal mission at the Hanford Site. The Tank Waste Retrieval and Disposal mission is one of three primary missions under the River Protection Project. The Tank Waste Retrieval and Disposal mission includes the programs necessary to support tank waste retrieval; waste feed, delivery, storage, and disposal of immobilized waste; and closure of tank farms. Completion of this mission enables the tank farms to be closed and turned over for final remediation.

The technical baseline is defined as the set of science and engineering, equipment, facilities, materials, qualified staff, and enabling documentation needed to start up and complete the mission objectives. The primary purposes of this document are (1) to identify the important technical information that should be used by contributors to the mission and (2) to serve as a basis for configuration management of the technical information.

Although this document focuses on the Tank Waste Retrieval and Disposal mission portion of the River Protection Project, its contents will be incorporated into a similar document that will represent the entire River Protection Project. This document is updated regularly to ensure that the technical baseline documents and source information identified herein are maintained current. Changes to this document are consistent with applicable configuration management procedures. 


\section{HNF-1901 Rev 1}

This page intentionally left blank. 


\section{CONTENTS}

$1.0 \quad$ INTRODUCTION

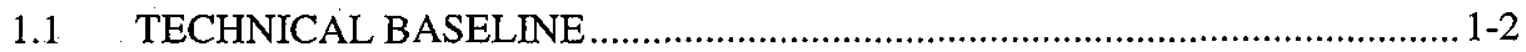

1.2 STRUCTURE AND CONTENT OF DOCUMENT ………….......................... 1-7

2.0 TANK WASTE RETRIEVAL AND DISPOSAL MISSION

SCOPE AND REQUIREMENTS ..............................................................................2-1

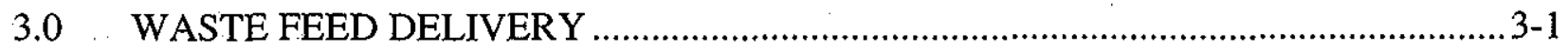

3.1 PRIMARY WASTE DEFINITION …….................................................... 3-4

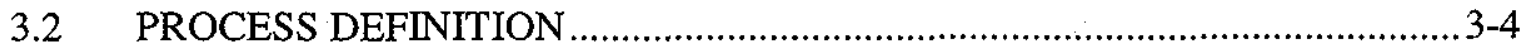

3.2.1 Low-Activity Waste Feed Delivery - Phase 1.......................................... 3-5

3.2.2 High-Level Waste Feed Delivery - Phase 1 ............................................... 3-5

3.3 MISSION PLANNING ............................................................................... 3-5

3.4 STRUCTURES, SYSTEMS, AND COMPONENTS ….................................. 3-6

3.4.1 System and Project Definition.................................................................

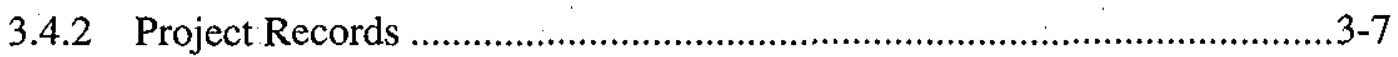

3.4.3 Reliability, Availability, and Maintainability Risk Evaluation.................3-7

3.4.4 Spare Equipment List .........................................................................

3.5 OPERATIONS, MAINTENANCE, AND SUPPORTING DOCUMENTS …....3-8

3.5.1 Operations and Maintenance Concept.................................................3-8

3.5.2 Permits and Safety Authorizations .......................................................

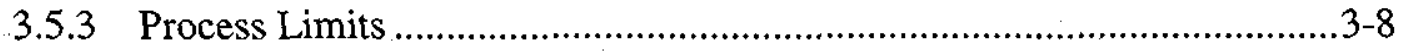

3.5.4 Safety Equipment List ..................................................................... 3-9

3.5.5 Operations and Maintenance Environmental, Safety, and Health Plans....................................................................

3.5.6 Operations and Maintenance Procedures ………......................................3-9

3.5.7 Training Certification ........................................................................ $3-9$

3.5.8 Operations and Maintenance Records................................................... 3-10

3.6 SECONDARY WASTE DEFINITION ……….......................................... $3-10$

3.7 PROGRAMMATIC INTERFACES …………............................................ 3-10

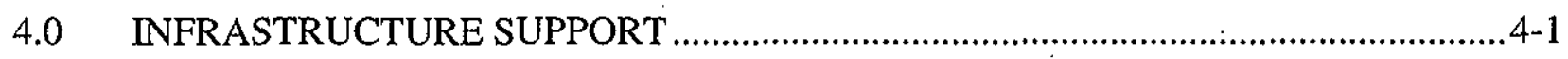

4.1 PRIMARY WASTE AND PRODUCT DEFINITIONS ..................................... $4-1$

4.2 PROCESS DEFINITION ......................................................................

4.2.1 Land for Siting ................................................................................. $4-3$

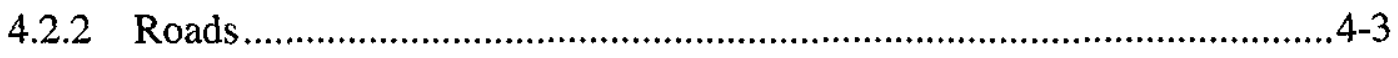

4.2.3 Raw and Potable Water.......................................................................4-3

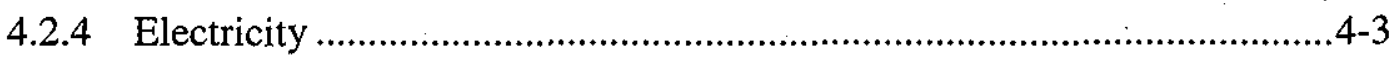

4.2.5 Effluent Waste Transfer .......................................................................4-3 
4.2.6 Radioactive Solid Waste ......................................................................

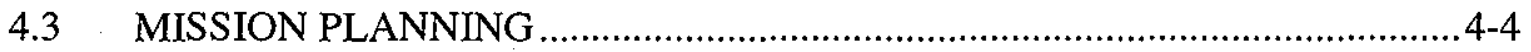

4.4 STRUCTURES, SYSTEMS AND COMPONENTS …………...................... $4-4$

4.4.1 Systems and Project Definition ...............................................................4-4

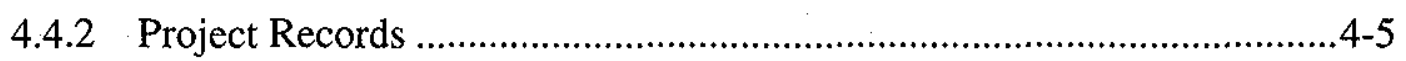

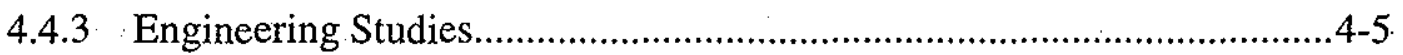

4.4.4 Spare Equipment List ...............................................................................4-5

4.5 OPERATIONS, MAINTENANCE, AND SUPPORTING DOCUMENTS .......4-5

4.5.1 Operations and Maintenance Concept....................................................4-6

4.5.2. Permits and Safety Authorizations .......................................................4-6

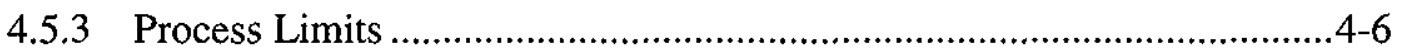

4.5.4 Safety Equipment List .....................................................................

4.5.5 Operations and Maintenance Environmental, Safety, and Health and Quality Assurance Plans.........................................................................4-7

4.5.6 Operations and Maintenance Procedures ................................................4-7

4.5.7 Training Certifications ….....................................................................

4.5.8 Operations and Maintenance Records ...................................................4-7

4.6 SECONDARY WASTE DEFINITION ……............................................. 4-8

4.7 . PROGRAMMATIC INTERFACES ..............................................................

$5.0 \quad$ PRIVATIZATION CONTRACT INTERFACES ......................................................

5.1 INPUT INTERFACE CONTROL DOCUMENTS …….................................

5.1.1 Low-Activity Waste Feed (ICD 19) ......................................................5-6

5.1.2 High-Level Waste Feed (ICD 20) ......................................................

5.2 SUPPORTING SYSTEM INTERFACE CONTROL DOCUMENTS.................5-6

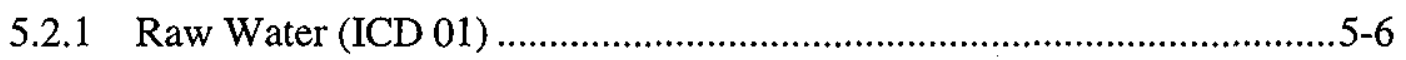

5.2.2 Potable Water (ICD 02) ...................................................................

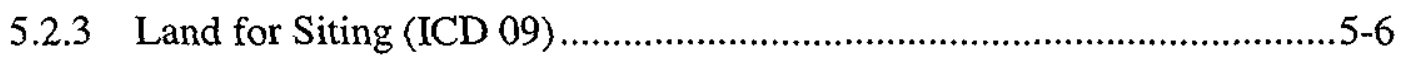

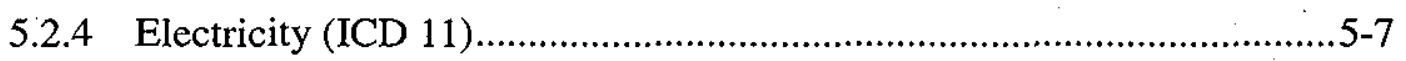

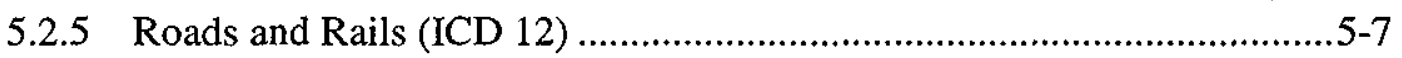

5.2.6 Air Emissions (ICD 22) ................................................................

5.2.7 Waste Treatability Samples (ICD 23) …………...................................

5.2.8 Emergency Response (ICD 25) .......................................................

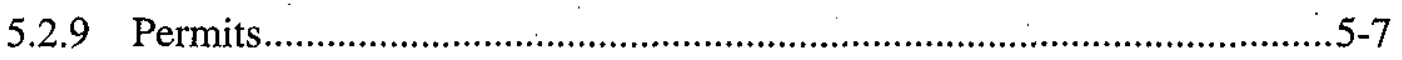

5.3 OUTPUT INTERFACE CONTROL DOCUMENTS ........................................5-8

5.3.1 Radioactive Solid Wastes (ICD 03) .....................................................

5.3.2 Nonradioactive, Nondangerous Liquid Effluent (ICD 05).......................5-8

5.3.3 Radioactive, Dangerous Liquid Effluents (ICD 06)...............................5-8

5.3.4 Deactivated Facility and Site (ICD 10) ……........................................

5.3.5 Immobilized High-Level Waste (ICD 14) .............................................5-9 
5.3.6 Immobilized Low-Activity Waste (ICD 15) ...........................................5-9

5.3.7 Entrained Solids (ICD 16) ..................................................................5-9

6.0 PRODUCT STORAGE AND DISPOSAL .................................................................

6.1 … PRIMARY WASTE AND PRODUCT DEFINITIONS ……….......................... 6-1

6.2 PROCESS DEFINITION ..........................................................................6-5

6.2.1. Immobilized Low-Activity Waste..........................................................6-6

6.2.2 Immobilized High-Level Waste ...........................................................6-6

6.2.3 Cesium/Strontium Capsules ...............................................................6-7

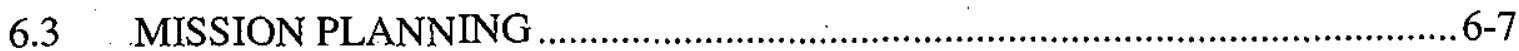

6.4 STRUCTURES, SYSTEMS, AND COMPONENTS ………….........................6-7

6.4.1 System and Project Definition............................................................6-8

6.4.2 Project Records ................................................................................6-9

6.4.3 Reliability, Availability, and Maintainability Risk Evaluation................6-9

6.4.4 Spare Equipment List ..........................................................................6-9

6.5 OPERATIONS, MAINTENANCE, AND SUPPORTING DOCUMENTS ..... 6-10

6.5.1. Operations and Maintenance Concept...................................................6-10

6.5.2 Permits and Safety Authorizations.......................................................

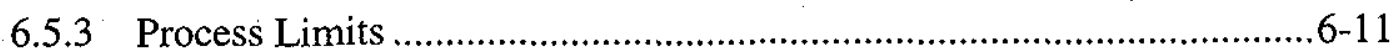

6.5.4 Safety Equipment List....................................................................6-11

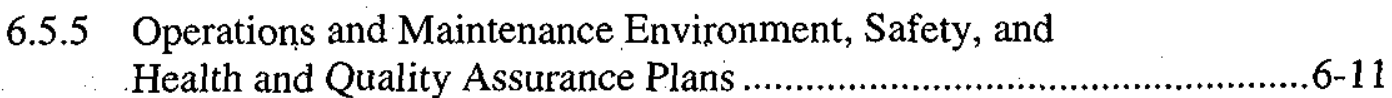

6.5.6 . Operations and Maintenance Procedures ................................................6-11

6.5.7 Training Certifications ..............................................................6-11

6.5.8 Operations and Maintenance Records .................................................

6.6 SECONDARY WASTE DEFINITION .................................................... 6-12

6.7 PROGRAMMATIC INTERFACES ...........................................................6-12

7.0 SECONDARY WASTE MANAGEMENT AND ANALYTICAL SUPPORT ............... 7-1

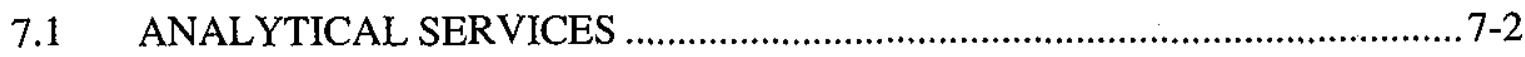

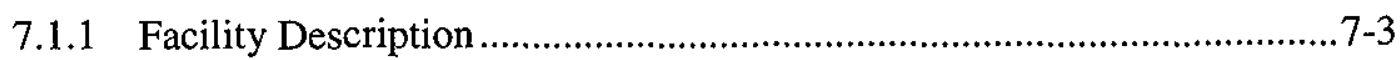

7.1.2 Sample Receiving Capabilities and Limitations .......................................

7.1.3 Facility Discharges ........................................................................... 7-3

7.1.4 Programmatic and Technical Interfaces...................................................7-4

7.1.5 Additional Required and Supplemental Documentation............................7-4

7.2 242-A EVAPORATOR ...........................................................................

7.2.1 Facility Description............................................................................ 7-5

7.2.2 Waste Receiving Capabilities and Limitations ........................................7-5

7.2.3 Facility Discharges .......................................................................

7.2.4 Programmatic and Technical Interfaces ..................................................

7.2.5 Additional Required and Supplemental Documentation...........................7-6 
7.3 EFFLUENT TREATMENT FACILITY/LIQUID EFFLUENT

RETENTION FACILITY .....................................................................

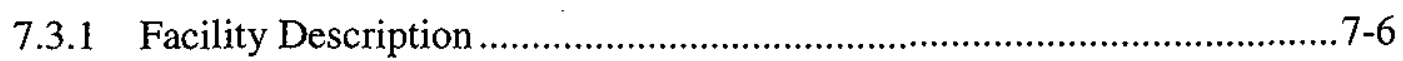

7.3.2 Waste Receiving Capabilities and Limitations ................................ 7-7

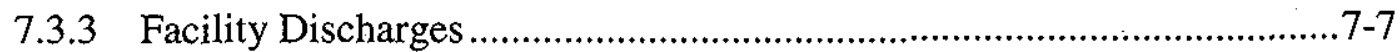

7.3.4 Programmatic and.Technical Interfaces ............................................7-7

7.3.5 Additional Required and Supplemental Documentation.........................7-7

7.4200 EAST AREA TREATED EFFLUENT DISPOSAL FACILITY ............... 7-8

7.4.1 Facility Description ................................................................

7.4.2 ..Waste Receiving Capabilities and Limitations ................................ 7-8

7.4.3 Facility Discharges ....................................................................... $7-8$

7.4.4 Programmatic and Technical Interfaces ...........................................7-8

7.5 STATE-APPROVED LAND DISPOSAL SITES ....................................... $7-9$

7.6 CENTRAL WASTE COMPLEX ...........................................................

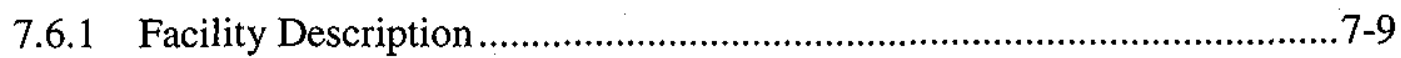

7.6.2 ...Waste Receiving Capabilities and Limitations ............................... 7-9

7.6.3 Facility Discharges ................................................................. $7-10$

7.6.4 Programmatic and Technical Interfaces .............................................7-10

7.6.5 Additional Required and Supplemental Documentation......................7-10

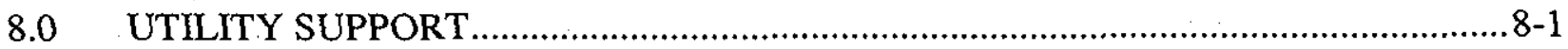

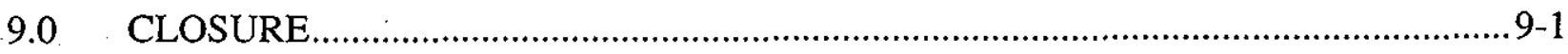

9.1 PRIVATE CONTRACTOR FACILITIES ............................................ $9-1$

9.2 IMMOBILIZED WASTE FACILITIES ...................................................... 9-2

9.2.1 Immobilized Low-Activity Waste Facilities ......................................9-2

9.2.2 Immobilized High-Level Waste Facilities ............................................9-2

9.3 TANK FARM SYSTEMS ..........................................................................

9.4 OTHER PROJECT HANFORD MANAGEMENT CONTRACT TEAM SUPPORTING FACILITIES ............................................................. 9-3

\section{APPENDICES}

A WASTE RETRIEVAL AND DISPOSAL MISSION SCOPE DOCUMENTS .............. A-i

B WASTE FEED DELIVERY DOCUMENTS ....................................................... B-i

C INFRASTRUCTURE SUPPORT DOCUMENTS .................................................

D PRIVATE CONTRACTOR INTERFACE DOCUMENTS ................................... D-i

E PRODUCT STORAGE AND DISPOSAL DOCUMENTS ....................................... E-i 
F SECONDARY WASTE MANAGEMENT AND ANALYTICAL SUPPORT DOCUMENTS F-i

G REFERENCES. $\mathrm{G}-\mathrm{i}$

H GUIDANCE AND REQUIREMENTS TO DELIVERABLES CROSSWALK RPP RETRIEVAL AND DISPOSAL MISSION TECHNICAL

BASELINE SUMMARY DESCRIPTION $\mathrm{H}-\mathrm{i}$

\section{FIGURES}

Figure 1. Relationship of Waste Retrieval and Disposal Mission Elements to the River Protection Project.

Figure 2. Top-Level Summary of Technical Bases for Operations, Consistent with DOE Orders 425.1 and 430.1 .

Figure 3. Engineering Process Flow Diagram, .............................................................. 1-4

Figure 4. General Configuration and Flow of Technical Baseline Information. ...................... 1-5

Figure 5. Relationship of Contractors, Their Roles, and Location of Technical.Baseline Information in this Document.

Figure 6. Major Facilities and Process Flows for the Waste Retrieval and Disposal Mission.

\section{TABLES}

Table 1. Cross-Cutting Waste Retrieval and Disposal Mission Technical Baseline Documents and Designated Source Information. $2-3$

Table 2. Waste Feed Delivery System Documents and Designated Source Information 3-1

Table 3. Interface Categories and Requirements of Privatization Contracts. ${ }^{a}$ $5-2$

Table 4. Privatization Interface Control Documents and Designated Source Information........5-3

Table 5. Summary of Source Product Storage and Disposal Documents $6-2$

Table 6. Technical Baseline Documents for Secondary Waste and Analytical Services and Designated Source Information. 
HNF-1901 Rev 1

Table 7. Utilities Support Documents and Designated Source Documents................................. 8-1

Table 8. Summary of Source Tank Closure/Other Interfaces. ...................................................9-1 


\section{TERMS}

$\mathrm{BIO}$

BNFL

CFR

CSB

CWC

DMMC

DOE

DST

DYN

Ecology

EPA

ES\&H

ETF

FDH

FY

HLW

HSTD

ICD

IHLW

ILAW

IPPD

JCS

LAW

LERF

LLW

LMHC

NEPA

PHMC

RAM

RCRA

RPP

S/RID

SALDS

SNF

SSC

SST

TEDF

TCR basis for interim operation

BNFL Inc.

Code of Federal Regulations

Canister Storage Building

Central Waste Complex

document/information management center

U.S. Department of Energy

double-shell tank

DynCorp Tri-Cities Services, Inc.

Washington State Department of Ecology

U.S. Environmental Protection Agency

environment, safety, and health

Effluent Treatment Facility

Fluor Daniel Hanford, Inc.

fiscal year

high-level waste .

Hanford Site Technical Baseline Database

interface control document

immobilized high-level waste

immobilized low-activity waste

integrated product and process development

Job Control System

low-activity waste

Liquid Effluent Retention Facility

low-level waste

Lockheed Martin Hanford Corporation

National Environmental Policy Act of 1969

Project Hanford Management Contract

reliability, availability, and maintainability

Resource Conservation and Recovery Act of 1976

River Protection Project

standards/requirements identification document

State-Approved Land Disposal Site

spent nuclear fuel

structures, systems, and components

single-shell tank

Treated Effluent Disposal Facility

tank characterization report 
HNF-1901 Rev 1

\section{TERMS (cont)}

Tri-Party. Agreement TRU

TSR

TWR\&D

WMH
Hanford Federal Facility Agreement and Consent Order transuranic technical safety requirement Tank Waste Retrieval and Disposal (organization) Waste Management Federal Services of Hanford, Inc. 


\section{RIVER PROTECTION PROJECT RETRIEVAL AND \\ DISPOSAL MISSION TECHNICAL BASELINE SUMMARY DESCRIPTION}

\subsection{INTRODUCTION}

This document provides a summary description of the technical baseline for the Tank Waste Retrieval and Disposal (TWR\&D) mission, a major element of the River Protection Project (RPP). The TWR\&D mission includes the programs necessary to support RPP tank waste retrieval, delivery, storage, and disposal and tank farm closure. Treatment and disposal of tank waste currently is planned to occur in two phases. Under Privatization Phase 1 (a demonstration phase), the Private Contractor builds, owns, and operates facilities to verify that treatment and immobilization processes function effectively. Privatization Phase 2 (a full-scale production phase) will be developed using the information and results from Phase 1. Figure 1 depicts the relationship of the TWR\&D mission elements to the RPP. The full range of RPP missions and objectives is discussed in more detail in HNF-SD-WM-MAR-008, River Protection Project Mission Analysis Report (Acree 1998).

Figure 1. Relationship of Waste Retrieval and Disposal Mission Elements to the River Protection Project.
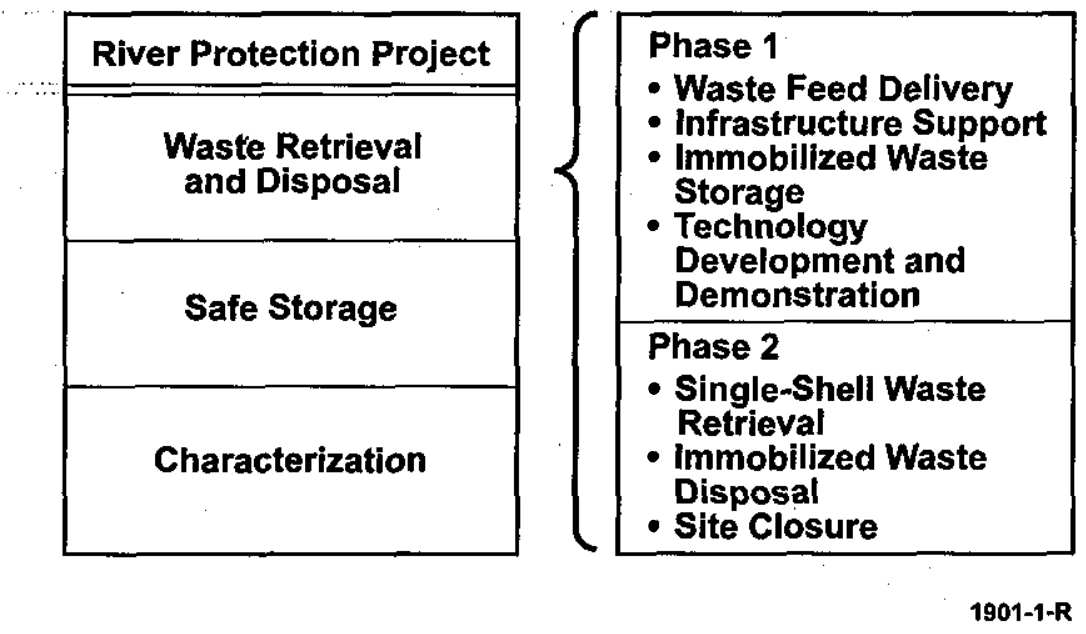

The RPP is operated by Lockheed Martin Hanford Corporation (LMHC). The RPP includes operation and maintenance of the single-shell tanks (SST) and double-shell tanks (DST); retrieval of low-activity waste (LAW) and high-level waste (HLW) from the DSTs, SSTs, and miscellaneous underground storage tanks; delivery of the tank waste to treatment and immobilization facilities; interim storage and disposal of immobilized LAW (ILAW); temporary storage and final disposition of immobilized HLW (IHLW); management of secondary wastes and byproducts; and safe closure of the DSTs, SSTs, miscellaneous underground storage tanks, and tank farm facilities. The technical baseline for the TWR\&D mission provides the basis for planning and managing technical objectives over the life cycle of the mission. This technical baseline summary description serves the following purposes: 
- Identifies those documents that represent the technical baseline for the TWR\&D mission

- Designates source information for technical bases

- Defines the organization responsible for each technical baseline document

- Identifies configuration information to be managed under graded configuration management requirements.

This document presently focuses on the TWR\&D mission portion of the RPP; in the future it will be incorporated into a similar document that represents the entire RPP.

\subsection{TECHNICAL BASELINE}

The technical baseline is the set of science and engineering, equipment, facilities, materials, qualified staff, and enabling documentation needed to start up and complete mission objectives. The documents that represent the technical baseline include those necessary to support a successful operational readiness review or readiness assessment in accordance with DOE Order 425.1, Startup and Restart of Nuclear Facilities. Figure 2 shows that technical baseline development follows mission definition and planning. The figure also shows that the technical baseline is structured to satisfy the requirements for a successful operational readiness review or readiness assessment and continued operations for the life cycle of the mission.

The technical baseline contains three parts: the requirements baseline, the design baseline, and the operational baseline. The River Protection Project Systems Engineering Management Plan, HNF-SD-WM-SEMP-002 (Peck 1999), provides additional detail on the content of the technical baseline. Figure 3 shows examples of technical information included in each part of the technical baseline. The relationship of technical information included in the technical baseline is shown in Figure 4. 
Figure 2. Top-Level Summary of Technical Bases for Operations, Consistent with DOE Orders 425.1 and 430.1A.

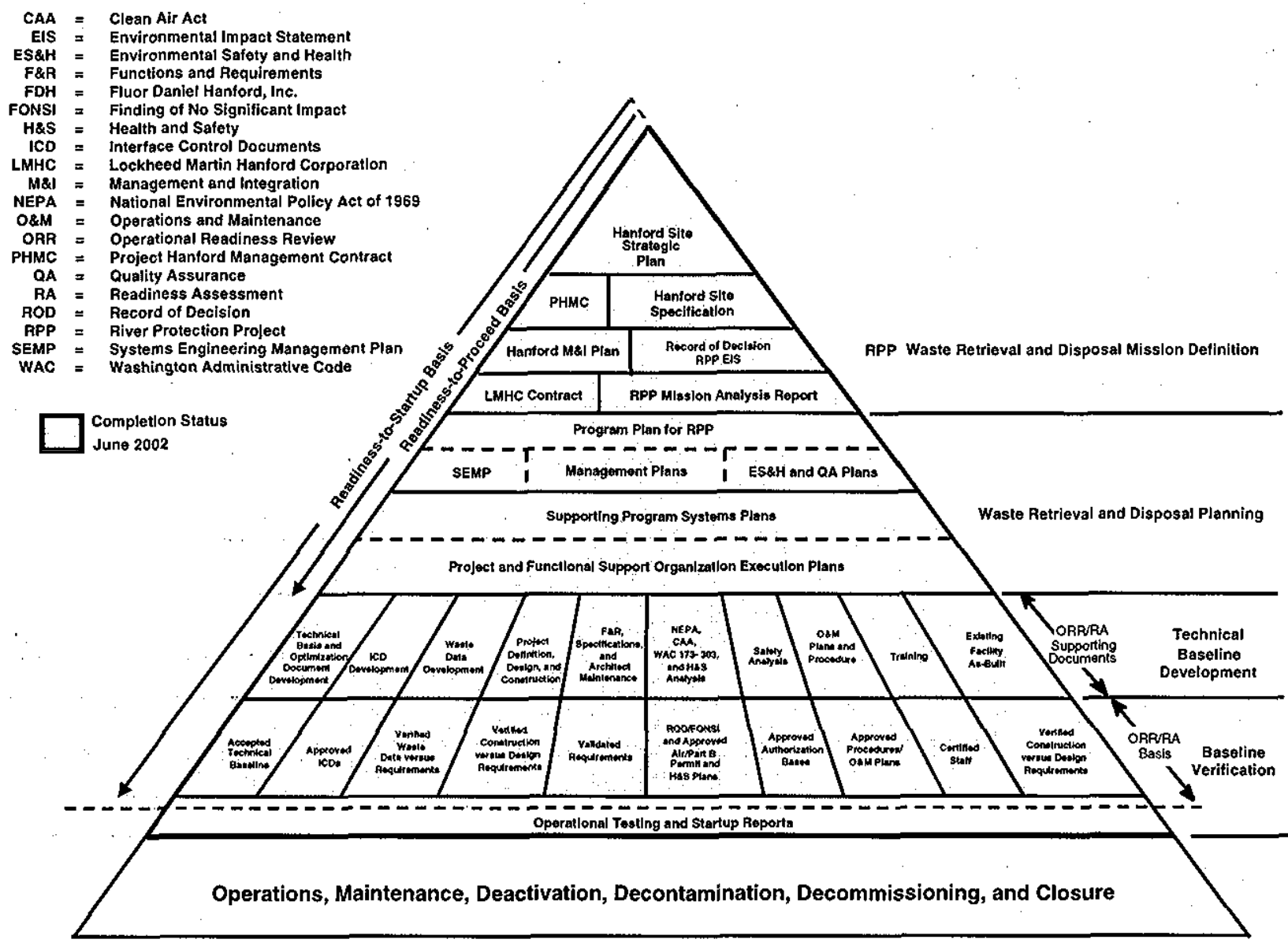

1901-2-8 
HNF-1901 Rev 1

Figure 3. Engineering Process Flow Diagram.

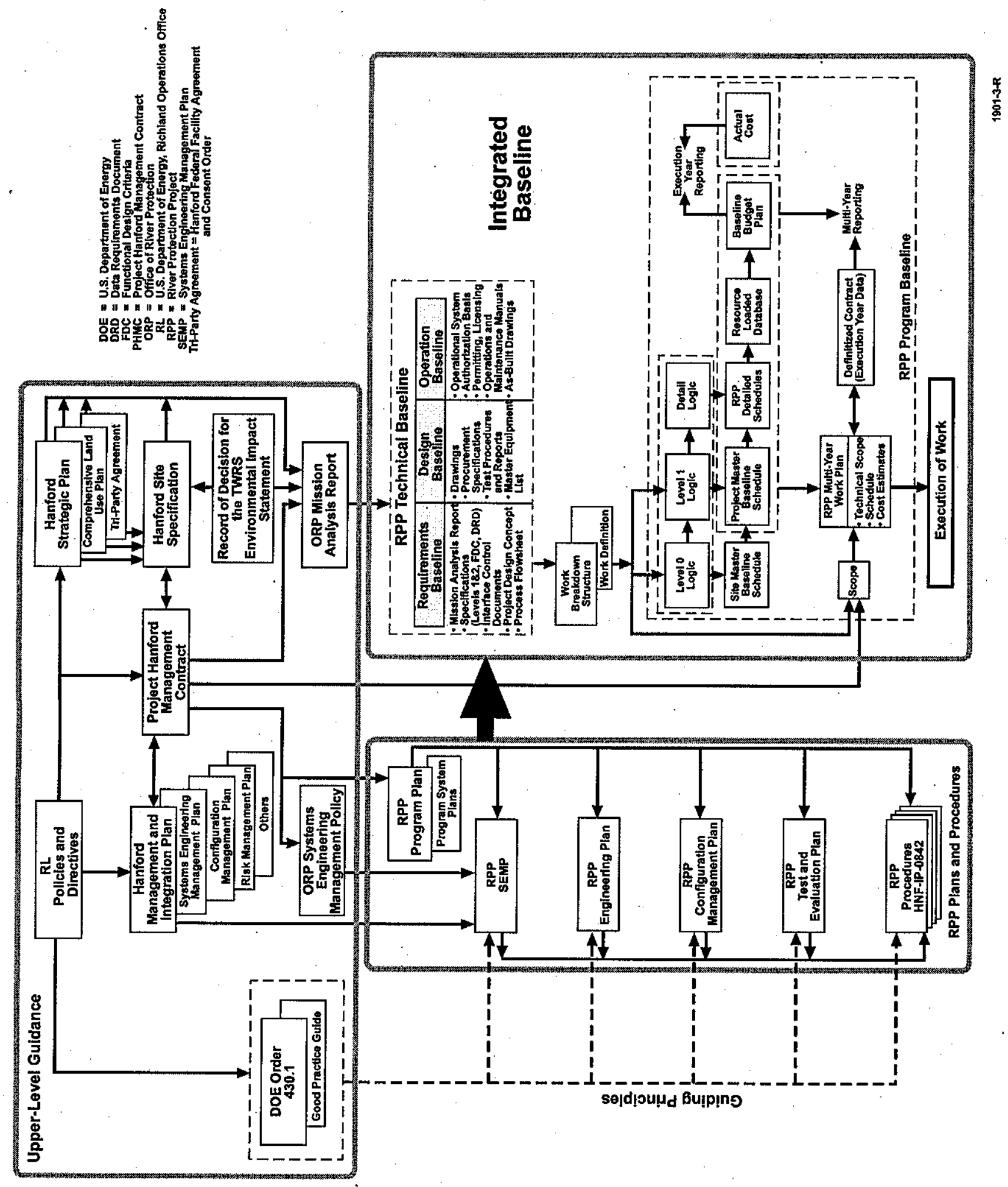


Figure 4. General Configuration and Flow of Technical Baseline Information.

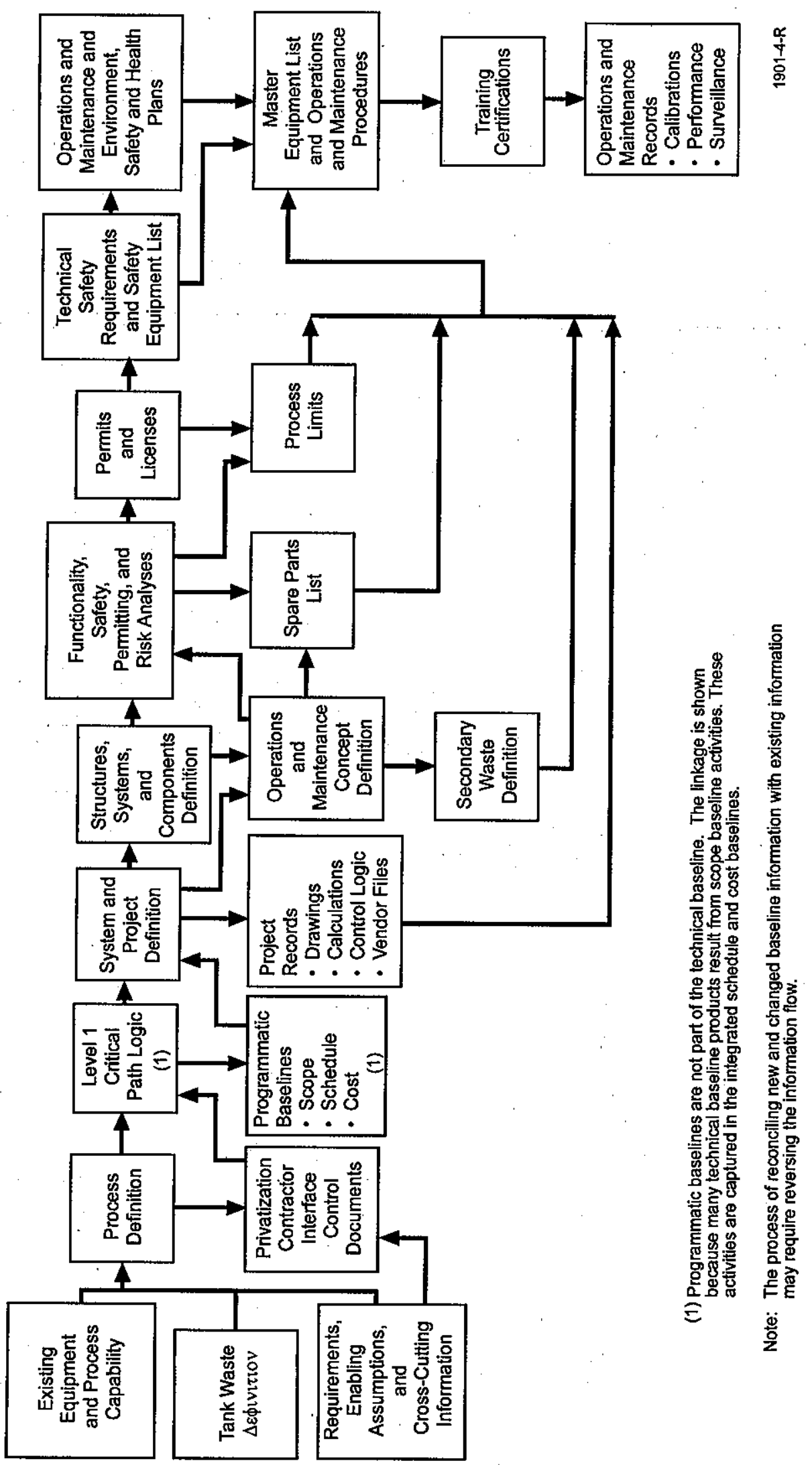


The technical baseline is generated using the iterative systems engineering process. The technical baseline has been planned to evolve with the RPP in the succeeding years in accordance with the schedule and budget. The sequence of preparing technical baseline documents is generally consistent with the technical baseline information process outlined in Figure 4. The process for identifying, developing, and maintaining the RPP technical baseline documents is described in more detail in HNF-1947, Tank Waste Remediation System Engineering Plan (Rifaey 1998).

Technical baseline documents serve as inputs to, or are products of, work scope activities. The durations and costs of the work scope activities, including development of technical baseline documents, are defined in the RPP logic diagrams. Relating the mission's technical baseline documents to the logic diagrams ensures that correct technical information is identified for its required use and aids in the development of future technical baseline information.

In accordance with HNF-1947 (Rifaey 1998) and HNF-1900, Tank Waste Remediation System Configuration Management Plan (Vann et al. 1998), the RPP Technical Operations and Engineering organization is responsible for maintaining the technical baseline and this technical baseline summary description. Maintaining this summary description document includes the following:

- Reviewing new and revised technical baseline documents

- Assigning document categories (e.g., configuration information, requirement, source document) and identifying the source information for each document

- Preparing technical baseline document summaries for inclusion in the appendices of this summary description document

- Updating this summary description document as new information becomes available.

The RPP Technical Operations and Engineering organization also is responsible for managing the lists of configuration information provided in the source information tables in each section of this document, consistent with HNF-1900 (Vann et al. 1998), assessing the configuration impact of each document, and directing accordingly all owners of potentially impacted predecessor and successor technical baseline documents. Configuration items/information are selected for control based on importance to the RPP and TWR\&D mission and risks that would result from inadequacy of the product. Once the item/information has been selected to be controlled and maintained current, it is entered into an information system that statuses the release and revision history of such items. This information system is updated throughout the configuration item's life cycle and made accessible to users. Document control and configuration procedures are implemented to ensure that only currently approved revisions of configuration documents are used to conduct work.

Organizations that contribute to the RPP are responsible for using designated source information as the basis for preparing and revising their work. These organizations also are responsible for submitting new and revised technical baseline documents to the RPP Technical Operations and Engineering organization for assessment of configuration impacts and to update and maintain the technical baseline. Contributing organizations use satellite document/information management 
centers (DIMC) to receive and transmit documentation and information associated with the RPP and the TWR\&D mission. The DIMCs provide the technologies and services to manage both incoming and internally created documents, including technical baseline documents, so that information is accessible across the RPP. The DIMC services include document scanning, indexing, document release, document clearance and distribution, storage, records disposition and transfer, commitment tracking, and similar services as required. Documents and media (including technical baseline documents) are stored and/or accessible through the Records Management Information System. The RPP programs and organizations are responsible for identifying the documents and information systems to be controlled and shared.

\subsection{STRUCTURE AND CONTENT OF DOCUMENT}

The RPP contractor and the PHMC team have specific roles in executing the TWR\&D mission. Technical baseline information is developed by each contractor. Figure 5 relates the TWR\&D mission contractors and their roles to Sections 2.0 through 9.0 of this document. The contents of each of these sections, along with the lead responsible organization, are as follows.

- Section 2.0 provides a high-level summary of the background, decision documents, mission sources, and crosscutting requirements information for the TWR\&D mission (responsible organization: $\mathrm{LMHC}$ ).

- Section 3.0 addresses work and technical documents related to processing and retrieval of waste from the tanks and delivery of the waste feed to the Private Contractor (responsible organization: LMHC).

- Section 4.0 addresses work and technical documents related to providing infrastructure equipment and services (responsible organization: LMHC).

- Section 5.0 addresses work and interface control documents (ICD) related to the Private Contractor's work to treat and immobilize the tank waste (responsible organizations: Private Contractor and the interfacing PHMC team contractors, which include LMHC, Waste Management Federal Services of Hanford, Inc. [WMH], and DynCorp Tri-Cities Services, Inc. [DYN]).

- Section 6.0 addresses work and technical documents related to the PHMC team's receipt and disposal of ILAW and IHLW and other products from the Private Contractor (responsible organization: $\mathrm{LMHC}$ ).

- Section 7.0 addresses work and technical documents related to tank waste sample analysis and treatment, storage, and disposal of secondary wastes (responsible organization: WMH). 
Figure 5. Relationship of Contractors, Their Roles, and Location of

Technical Baseline Information in this Document.

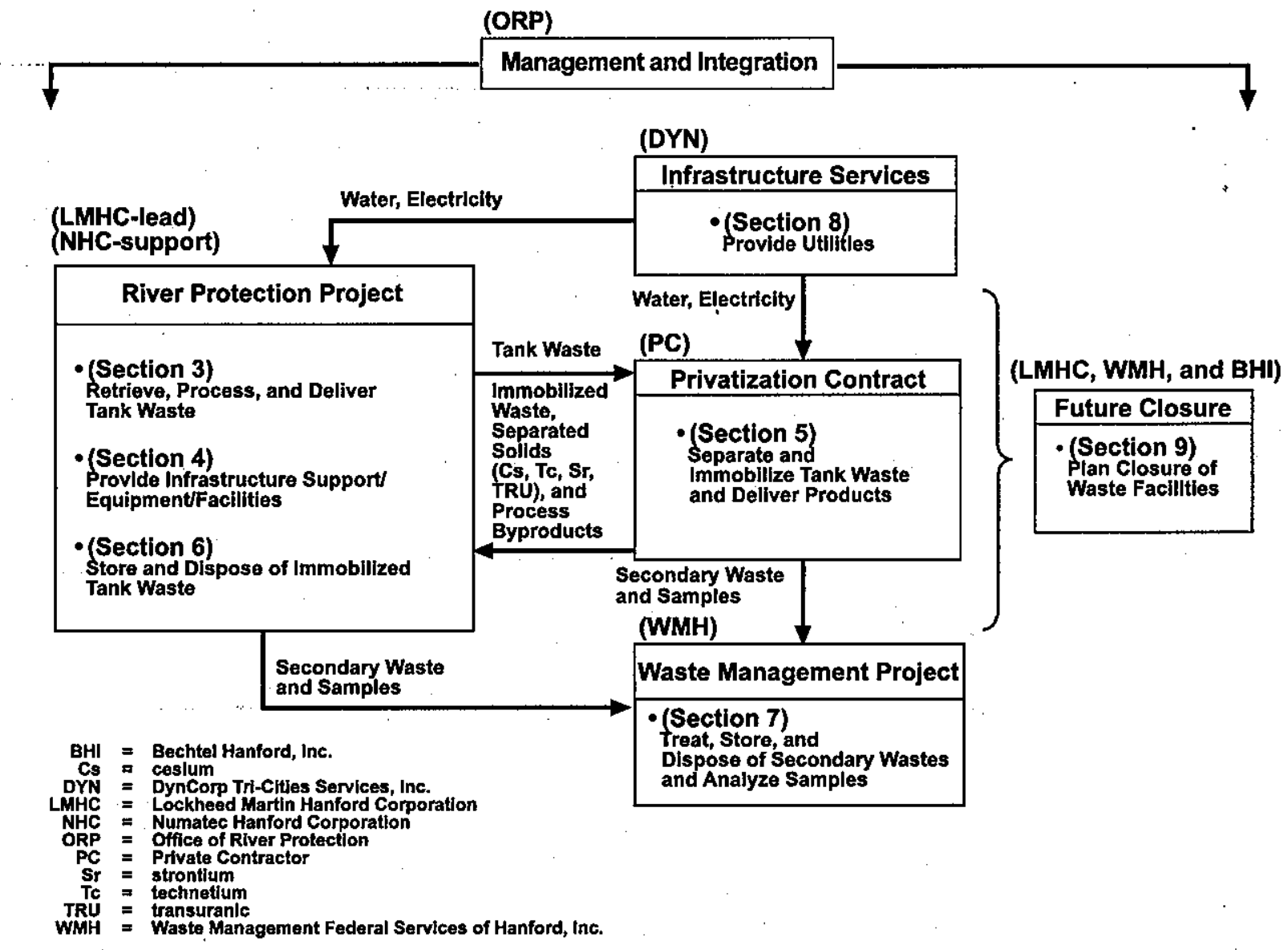

Note: Section numbers refer to sectlons in thls dociument

- Section 8.0 addresses work and technical documents related to provision of utility services (responsible organization: DYN).

- Section 9.0 addresses work and technical documents related to closing the tanks and associated facilities (responsible organizations: $\mathrm{LMHC}, \mathrm{WMH}$, and Bechtel Hanford, Inc.). 
This document contains eight appendices (A through $\mathrm{H}$ ). Appendices A through $\mathrm{F}$ support the eight scope areas described in Sections 2.0 through 9.0. The following summary information for each technical document is included in the corresponding appendix:

- Assigned document number and title

- Configuration management designation (i.e., maintained current, or not)

- Responsible organization

- Status of preparation/revision

- Source information designation (i.e., the specific information that resides in the document designated to represent element(s) of the technical baseline)

- Brief summary of content of entire document or information set

- Interrelated documents (i.e., successor and predecessor documents impacted by the document, including changes to the document).

Appendix $\mathrm{G}$ provides complete citations for the references used in this summary description document.

Appendix $\mathrm{H}$ provides the crosswalk between guidance/requirements and the deliverables. 


\section{HNF-1901 Rev 1}

This page intentionally left blank. 


\subsection{TANK WASTE RETRIEVAL AND DISPOSAL MISSION SCOPE AND REQUIREMENTS}

The TWR\&D mission, a major component of the RPP, was developed through strategic and technical decisions made by government agencies, stakeholders, and Hanford Site contractors. This section provides background information and cites documents used to develop the technical baseline for the TWR\&D mission. This section also summarizes the activities required for completion of the TWR\&D mission and directs the reader to other sections of this report regarding the retrieval and immobilization process.

Strategic decisions that led to establishing the TWR\&D mission included awarding of the Project Hanford Management Contract (PHMC) (RL 1996b) to FDH for management and integration of Hanford Site work and establishing agreements between FDH and LMHC for management of the RPP. Agreements also were established between FDH and other PHMC team members for support services (B\&W Hanford Company; DE\&S Hanford, Incorporated; DYN; Numatec Hanford Company; and WMH).

The technical baseline for the TWR\&D mission was developed from requirements and strategic considerations set forth in the following:

- Hanford Federal Facility Agreement and Consent Order (Tri-Party Agreement) (Ecology et al. 1996)

- DOE/EIS-0222D, Draft Hanford Remedial Action Environmental Impact Statement and Comprehensive Land Use Plan (DOE 1996a)

- DOE/RL 96-92, Hanford Strategic Plan, which sets specific goals for the retrieval and immobilization of the tank waste (RL 1996a)

- DOE/EIS-0189, Tank Waste Remediation System, Hanford Site, Richland, Washington, Final Environmental Impact Statement (DOE and Ecology 1996).

The U.S. Department of Energy's (DOE) selected approach and preferred alternatives for accomplishing the TWR\&D mission were set forth in 62 FR 8693, "Record of Decision for the Tank Waste Remediation System, Hanford Site, Richland, WA." The selected approach relies on a Private Contractor for a technology demonstration period (Privatization Phase 1), followed by full-scale operations (Privatization Phase 2) for tank waste retrieval, immobilization, and disposal. A contract has been established between DOE and a Private Contractor to accomplish the work: DE-AC-06-96RL13308, TWRS Privatization Contract (RL 1998).

Overall workflow and sequence for the RPP is depicted in the RPP Level 0 Logic (Fig. 6), which shows approximately 100 sequentially linked, broadly scoped activities. Requirements for the RPP and the TWR\&D mission are captured comprehensively in the Hanford Site Technical Baseline Database (HSTD), which is entered and maintained in a computer-based system called 
RDD- $100^{\circledR}$. Enabling assumptions for the RPP are captured in this database; and plans have been established to add risks, opportunities, and decisions to the HSTD. In addition to the HSTD, the Standards/Requirements Information Document, WHC-SD-MP-SRID-001, HighLevel Waste Storage Tank Farms/242-A Evaporator Standards/Requirements Identification Document (Biebesheimer 1996); identifies Federal, state, and professional technical requirements applicable to 20 functional areas (e.g., operations, maintenance, environmental protection) for performing work in the tank farms. Finally, HNF-SD-WM-MAR-008 (Acree 1998) integrates relevant policy, contractual, strategic, and other decisions with applicable requirements from the HSTD and the S/RID to describe the overall technical basis for the RPP and TWR\&D missions. Table 1 identifies these three cross-cutting documents (HSTD, S/RID, and HNF-SD-WM-MAR-008) as technical baseline documents (see Appendix A for detail).

The RPP is responsible for separating waste from selected tanks into an LAW supernatant (i.e., liquid fraction containing a very low solids content) and delivering LAW feed to the Private Contractor. The RPP also is responsible for delivering HLW feed to the Private Contractor. Activities associated with delivery of these waste feeds are shown in Figure 7 and discussed in Section 3.0 of this document. Section 4.0 describes infrastructure support that is provided to enable the Private Contractor to receive and manage the waste feed. The LAW and HLW streams are immobilized by the Private Contractor in accordance with the contractual requirements of the future Phase 1B private contract. Agreements on interfaces with the Private Contractor are established in ICDs, as discussed in Section 5.0 of this document.

Several secondary products and waste streams result from the waste feed and immobilization processes. Figure 7 shows these products and waste streams, along with their sources and expected destinations. The ILAW, IHLW, and separated solids and radionuclides are transferred from the Private Contractor to the RPP for management and disposal, as described in Section 6.0 of this document. Liquid effluent streams, samples, and other secondary wastes are received and dispositioned by WMH, as described in Section 7.0 of this document. Utility support (e.g., potable water, electricity) associated with the waste feed, immobilization, and management activities are provided by DYN, as discussed in Section 8.0 of this document. Following successful retrieval, empty tanks and associated facilities are closed and remediated as described in Section 9.0 of this document.

\footnotetext{
${ }^{\circledR} \mathrm{RDD}-100$ is a registered trademark of the Ascent Logic Corporation.
} 





Table 1. Cross-Cutting Tank Waste Retrieval and Disposal Mission Technical Baseline Documents and Designated Source Information.

\begin{tabular}{|c|c|c|c|}
\hline Document & $\begin{array}{l}\text { Maintained } \\
\text { current?* }\end{array}$ & $\begin{array}{l}\text { Appendix } \\
\text { number }\end{array}$ & Source information \\
\hline $\begin{array}{l}\text { Hanford Site Technical } \\
\text { Baseline Database (HSTD) }\end{array}$ & Yes & A. 1 & $\begin{array}{l}\text { Defines sitewide technical } \\
\text { requirements for conducting Hanford } \\
\text { Site work. }\end{array}$ \\
\hline $\begin{array}{l}\text { WHC-SD-MP-SRID-001, } \\
\text { High-Level Waste Storage } \\
\text { Tank Farms/ } \\
\text { 242-A Evaporator } \\
\text { Standards/Requirements } \\
\text { Identification Document } \\
\text { (Biebesheimer 1996) }\end{array}$ & Yes & A. 2 & $\begin{array}{l}\text { Defines operating, maintenance, } \\
\text { environmental, safety, and other } \\
\text { requirements for conducting work in } \\
\text { the Hanford Site tank farms. }\end{array}$ \\
\hline $\begin{array}{l}\text { HNF-SD-WM-MAR-008, } \\
\text { River Protection Project } \\
\text { Mission Analysis Report } \\
\text { (Acree 1998) }\end{array}$ & Yes & A. 3 & $\begin{array}{l}\text { Establishes River Protection Project } \\
\text { requirements, including the problem } \\
\text { definition, mission statement, initial } \\
\text { state conditions, acceptable end state, } \\
\text { major boundaries and interfaces, } \\
\text { mission analysis-level issues and } \\
\text { assumptions, and the technical } \\
\text { strategy basis. Also included are } \\
\text { externally imposed requirements, } \\
\text { including applicable Federal, state, } \\
\text { and local legislation, as well as } \\
\text { associated statutes, regulations, } \\
\text { codes, and standards. }\end{array}$ \\
\hline
\end{tabular}

*Is the document to be maintained current per HNF-1900, Tank Waste Remediation System Configuration Management Plan (Vann et al. 1998)? 
Figure 7. Major Facilities and Process Flows for the Tank Waste Retrieval and Disposal Mission.

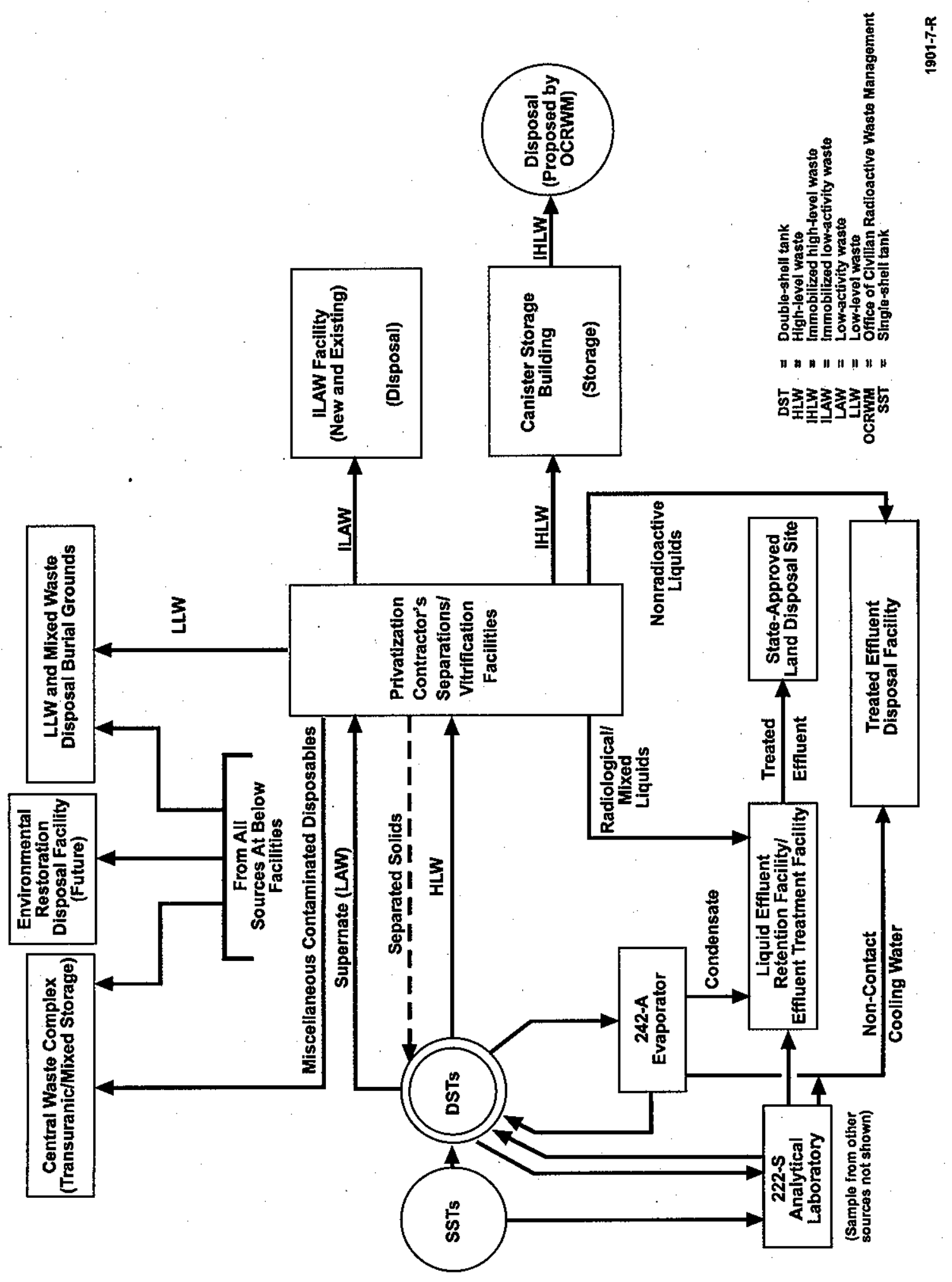




\subsection{WASTE FEED DELIVERY}

The Waste Feed Delivery Program is an element of the TWR\&D mission of the RPP (see Fig. 1). This section briefly summarizes the scope of the Waste Feed Delivery Program and, in this context, identifies technical baseline documents that support startup and continued operations throughout the mission. Table 2 lists the technical baseline documents identified to date for the Waste Feed Delivery Program, along with each document's source information. A brief summary of each document and other pertinent information is contained in Appendix B.

Table 2. Waste Feed Delivery System Documents and Designated Source Information. ( 3 sheets)

\begin{tabular}{|c|c|c|c|}
\hline Document & $\begin{array}{l}\text { Maintained } \\
\text { current?* }\end{array}$ & $\begin{array}{l}\text { Appendix } \\
\text { number }\end{array}$ & Source information \\
\hline $\begin{array}{l}\text { HNF-SD-WM-PLN-126, } \\
\text { FY } 1997 \text { - } 1998 \text { Waste } \\
\text { Information Requirements } \\
\text { Document } \\
\text { (Winkleman et al. 1997) }\end{array}$ & No & B.1 & $\begin{array}{l}\text { Annual plan for tank waste } \\
\text { sampling activities, approved by } \\
\text { the U.S. Department of Energy and } \\
\text { Washington State Department of } \\
\text { Ecology. }\end{array}$ \\
\hline $\begin{array}{l}\text { HNF-SD-WM-TI-740, } \\
\text { Standard Inventories of } \\
\text { Chemicals and } \\
\text { Radionuclides in Hanford } \\
\text { Site Tank Wastes } \\
\text { (Kupfer et al. 1999) }\end{array}$ & Yes & B. 2 & $\begin{array}{l}\text { Best-basis inventory of the } \\
\text { chemical and radiological contents } \\
\text { of tank farm wastes. }\end{array}$ \\
\hline $\begin{array}{l}\text { Tank characterization } \\
\text { reports (TCR) (see } \\
\text { Appendix B and } \\
\text { Appendix G) }\end{array}$ & Yes & B. 3 & $\begin{array}{l}\text { Best-basis inventories for the } 177 \\
\text { individual single- and double-shell } \\
\text { tanks. }\end{array}$ \\
\hline $\begin{array}{l}\text { HNF-SD-WM-SP-012, } \\
\text { Tank Waste Remediation } \\
\text { System Operation and } \\
\text { Utilization Plan to Support } \\
\text { Waste Feed Delivery } \\
\text { (Kirkbride et al. 1999) }\end{array}$ & Yes & B. 4 & $\begin{array}{l}\text { The operating scenario and plans } \\
\text { for the delivery of feed to the } \\
\text { Private Contractor, retrieval of } \\
\text { waste from single- and double- } \\
\text { shell tanks, and the overall process } \\
\text { flowsheets. This document is the } \\
\text { source of the feed delivery system } \\
\text { process. }\end{array}$ \\
\hline
\end{tabular}


Table 2. Waste Feed Delivery System Documents and Designated Source Information.

(3 sheets)

\begin{tabular}{|c|c|c|c|}
\hline Document & $\begin{array}{l}\text { Maintained } \\
\text { current?* }\end{array}$ & $\begin{array}{l}\text { Appendix } \\
\text { number }\end{array}$ & Source information \\
\hline $\begin{array}{l}\text { HNF-2401, Waste Feed } \\
\text { Delivery Environmental } \\
\text { Permits and Approvals } \\
\text { Plan (Papp et al. 1998) }\end{array}$ & Yes & B. 5 & $\begin{array}{l}\text { Strategies needed to acquire } \\
\text { permits for waste feed activities. }\end{array}$ \\
\hline $\begin{array}{l}\text { HNF-SD-WM-TRD-007, } \\
\text { System Specification for the } \\
\text { Double-Shell Tank System } \\
\text { (Grenard et al. 1998) }\end{array}$ & Yes & B. 6 & $\begin{array}{l}\text { Top-level functional, performance, } \\
\text { design, development, interface, and } \\
\text { test requirements for the Double- } \\
\text { Shell Tank System. }\end{array}$ \\
\hline $\begin{array}{l}\text { Component specifications } \\
\text { for the DST system } \\
\text { (various) }\end{array}$ & Yes & B.7 & $\begin{array}{l}\text { Overall process design criteria for } \\
\text { new and modified equipment } \\
\text { supporting the waste feed delivery } \\
\text { system. }\end{array}$ \\
\hline $\begin{array}{l}\text { Project W-314 technical } \\
\text { baseline documents (see } \\
\text { listing of technical baseline } \\
\text { documents in Appendix G.) }\end{array}$ & Yes & B. 8 & $\begin{array}{l}\text { Technical baseline documents } \\
\text { related to the W-314 Project, Tank } \\
\text { Farm Restoration and Safe } \\
\text { Operations. }\end{array}$ \\
\hline $\begin{array}{l}\text { Project W-211 technical } \\
\text { baseline documents (see } \\
\text { listing of technical baseline } \\
\text { documents in Appendix G.) }\end{array}$ & Yes & B.9 & $\begin{array}{l}\text { Technical baseline documents } \\
\text { related to the W-211 Project, Initial } \\
\text { Tank Retrieval System. }\end{array}$ \\
\hline $\begin{array}{l}\text { Project W-521 technical } \\
\text { baseline documents (see } \\
\text { listing of technical baseline } \\
\text { documents in Appendix G.) }\end{array}$ & Yes & B. 10 & $\begin{array}{l}\text { Technical baseline documents } \\
\text { related to the W-521 Project, } \\
\text { Waste Feed Delivery Systems. }\end{array}$ \\
\hline $\begin{array}{l}\text { Project W- } 058 \text { cross-site } \\
\text { transfer line technical } \\
\text { baseline documents }\end{array}$ & Yes & B.11 & $\begin{array}{l}\text { Technical baseline documents } \\
\text { resulting from Project W-058, } \\
\text { Cross Site Transfer Line. }\end{array}$ \\
\hline $\begin{array}{l}\text { Project W- } 030 \text { aging waste } \\
\text { ventilation system technical } \\
\text { baseline documents }\end{array}$ & Yes & B. 12 & $\begin{array}{l}\text { Technical baseline documents } \\
\text { resulting from Project W-030, } \\
\text { Aging Waste Vent System. }\end{array}$ \\
\hline $\begin{array}{l}\text { Project W- } 320 \text { Tank C-106 } \\
\text { retrieval technical baseline } \\
\text { documents }\end{array}$ & Yes & B. 13 & $\begin{array}{l}\text { Technical baseline documents } \\
\text { resulting from Project W-320, } \\
\text { Tank C-106 Retrieval. }\end{array}$ \\
\hline
\end{tabular}


Table 2. Waste Feed Delivery System Documents and Designated Source Information. ( 3 sheets)

\begin{tabular}{|c|c|c|c|}
\hline Document & $\begin{array}{l}\text { Maintained } \\
\text { current?* }\end{array}$ & Appendix & Source information \\
\hline $\begin{array}{l}\text { Project:W-151 technical } \\
\text { baseline documents (see } \\
\text { listing of baseline } \\
\text { documents in Appendix G.) }\end{array}$ & Yes & B.14 & $\begin{array}{l}\text { Technical baseline documents } \\
\text { related to the W-151 Project, } \\
\text { AZ-101 Mixer Pumps. }\end{array}$ \\
\hline $\begin{array}{l}\text { HNF-2863, Waste Feed } \\
\text { Delivery System Phase } 1 \\
\text { Baseline RAM Assessment } \\
\text { (Papp 1998) }\end{array}$ & No & B. 15 & $\begin{array}{l}\text { Reliability, availability, and } \\
\text { maintainability risk evaluation } \\
\text { report. }\end{array}$ \\
\hline $\begin{array}{l}\text { DOE/RL } 88-21, \text { Hanford } \\
\text { Facility Dangerous Waste } \\
\text { Part A Permit Application } \\
\text { (RL 1999) }\end{array}$ & Yes & B.16 & $\begin{array}{l}\text { RCRA Part A Permit for the tank } \\
\text { farms as a hazardous waste } \\
\text { treatment storage and/or disposal } \\
\text { facility. }\end{array}$ \\
\hline $\begin{array}{l}\text { HNF-4474, RPP } \\
\text { Environmental Permits and } \\
\text { Related Documentation } \\
\text { (Dexter 1999) }\end{array}$ & Yes & B. 17 & $\begin{array}{l}\text { Current list of environmental } \\
\text { permits (including air, water, } \\
\text { dangerous waste) and related } \\
\text { documentation for RPP facilities } \\
\text { and activities. }\end{array}$ \\
\hline $\begin{array}{l}\text { HNF-SD-WM-BIO-001, } \\
\text { Tank Waste Remediation } \\
\text { System Basis for Interim } \\
\text { Operation (FDH 1999) }\end{array}$ & Yes & B. 24 & $\begin{array}{l}\text { Safety Authorization Basis for } \\
\text { operation of the tank farms. }\end{array}$ \\
\hline $\begin{array}{l}\text { HNF-SD-WM-TSR-006, } \\
\text { Tank Waste Remediation } \\
\text { System Technical Safety } \\
\text { Requirements } \\
\text { (LMHC 1999d) }\end{array}$ & Yes & B. 25 & Technical safety requirements. \\
\hline $\begin{array}{l}\text { HNF-SD-WM-SEL-040, } \\
\text { TWRS Facility Safety } \\
\text { Equipment List } \\
\text { (Jensen 1998) }\end{array}$ & Yes & B.26 & Facility safety equipment. \\
\hline
\end{tabular}

*Is the document to be maintained current per HNF-1900, Tank Waste Remediation System Configuration Management Plan (Vann et al. 1998)?

$\mathrm{FY}=$ fiscal year.

RCRA $=$ Resource Conservation and Recovery Act of 1976.

RPP $=$ River Protection Project. 


\subsection{PRIMARY WASTE DEFINITION}

Tank waste consists of byproducts from chemical separations processing of irradiated nuclear fuels. The waste is highly radioactive because it contains fission and activation products from the fuel as well as smaller amounts of uranium and other actinides. The waste also contains residuals of the chemicals used in various separations processes performed at the Hanford Site. Other chemical additions were made to the waste to minimize corrosion of the underground storage tanks. Although similarities exist between the waste in the tanks, each tank contains waste with a unique composition.

A "best-basis" inventory has been developed on a total-tank basis and for each of the 177 underground storage tanks. The best-basis inventory is located in HNF-SD-WM-TI-740, Standard Inventories of Chemicals and Radionuclides in Hanford Site Tank Wastes (Kupfer et al. 1999), and in 177 individual tank characterization reports (see Appendix B and Appendix G). These documents report work performed to date to establish standard total-tank and tank-by-tank component inventory estimates. The RPP Characterization Program establishes an annual plan for tank waste sampling activities. The plan is outlined in HNF-SD-WM-PLN-126, FY 1997 - 1998 Waste Information Requirements Document (Winkleman et al 1997). The TWR\&D organization is developing data quality objectives, which are used to define further tank waste characterization efforts.

\subsection{PROCESS DEFINITION}

The privatization contract (RL 1998) between DOE and the Private Contractor, BNFL Inc. (BNFL), is a source document for defining end-point requirements for the Waste Feed Delivery System. Under the DOE strategy, privatization takes place in two phases. In Privatization Phase 1 (demonstration phase) tank waste is retrieved and delivered to the Private Contractor by the RPP. In Privatization Phase 2 (production phase), retrieval and delivery of the waste may be privatized as well. The waste feed delivery process separates tank waste into an LAW fraction and an HLW fraction. The delivery of Phase 1 feed is planned to satisfy the compositional constraints of three LAW envelopes (A, B, and C) and one HLW envelope (D). These envelopes and the associated quantities of waste to be delivered are defined in the privatization contract. Specifications in the privatization contract were used to define planning assumptions for the Waste Feed Delivery Program and other programs supporting the TWR\&D mission.

The operating scenario and the sequence of waste retrieval and delivery to the Private Contractor based on planning assumptions and information on tank waste composition, existing or planned equipment and operational capabilities is defined in HNF-SD-WM-SP-012, Tank Waste Remediation System Operation and Utilization Plan to support Waste Feed Delivery (Kirkbride et al. 1999). The source of the process to be used for satisfying the envelope and delivery quantity requirements also is HNF-SD-WM-SP-012 (Kirkbride et al. 1999). Except for the HLW in two SSTs, DSTs are the sources of waste delivered and immobilized during Privatization Phase 1: HNF-SD-WM-SP-012 (Kirkbride et al. 1999) references laboratory testing and modeling that serve to establish the basis of the unit processes. The detailed flowsheets for these processes are defined in a set of waste feed delivery technical-basis flowsheets.(HNF-1939, Waste Feed Delivery Technical Summary Baseline, Volume II, 
Addendum 2-1, "Waste Feed Delivery Flowsheet for 241-AN-105" [Orme 1999a]; Volume II, Addendum 1-1, "Waste Feed Delivery Flowsheet for 241-AZ-101" [Orme 1999b]; Volume II, Addendum 3-1, "Waste Feed Delivery Flowsheet for 241-AN-104" [Orme 1999c]). To date, flowsheets have been developed specifically for delivery of waste from Tanks 241-AN-104, 241AN-105, and 241-AZ-101 to the Private Contractor. The flowsheets contain both mass and energy balances.

\subsubsection{Low-Activity Waste Feed Delivery - Phase 1}

In Privatization Phase 1, the RPP transfers LAW to Tanks AP-102 and AP-104 to allow the Waste Feed Delivery Program to stage, sample, and qualify waste to contractual requirements before delivery to the Private Contractor. After-mixing, sampling, analysis, and confirmation that the LAW meets the envelope requirements, the waste is transferred to the Private Contractor's LAW feed tank, Tank 241-AP-106. The Private Contractor transfers waste to their immobilization facility from this tank. Activities and technical documents related to the turnover of this tank to the Private Contractor are referenced in Section 4.0 of this document. Activities related to dissolution, dilution, and transfer of LAW to Tanks AP-102 and AP-104, and subsequent mixing, sampling, and analysis, are outlined in HNF-SD-WM-SP-012 (Kirkbride et al. 1999). Sources of LAW expected to satisfy envelopes A, B, and C also are defined in HNF-SD-WM-SP-012 (Kirkbride et al. 1999).

\subsubsection{High-Level Waste Feed Delivery - Phase 1}

In Privatization Phase 1, high-level waste sludges are mobilized into a slurry to produce HLW feed solids that satisfy envelope $D$ requirements and into a liquid phase that satisfies one of the three LAW envelopes. High-level waste feed is transferred to Tanks 241-AZ-101 and 241-AZ102 to allow the Waste Feed Delivery Program to stage, sample, and qualify the waste before delivery to the Private Contractor. After mixing, sampling, analysis, and confirmation that the material meets the envelope requirements, the waste is transferred to the Private Contractor's facility. The HLW feed contains a combination of transuranic (TRU) radionuclides and fission products in concentrations requiring permanent isolation in a Federal repository. Sources of HLW expected to satisfy envelope D requirements are defined in HNF-SD-WM-SP-012 (Kirkbride et al. 1999).

\subsection{MISSION PLANNING}

Activities required to achieve the objectives of the RPP are described in the RPP Level 0 Logic (Fig. 6). The Level 0 Logic depicts the activities that satisfy RPP mission objectives. The lower-level logic diagrams are more specific to the Waste Feed Delivery mission. The diagrams show detailed activities necessary to deliver feed to the Private Contractor during Privatization Phase 1B. Lower level logic diagrams and supporting analyses are the bases for multiyear work planning. Multiyear work plans are updated annually to incorporate the lower-level logic activities. Guidance for developing multiyear work plans includes specifications about which technical baseline documents to use, revise, and generate. 
Many of the technical baseline documents identified in this summary description serve as references or bases for completing logic activities; others are products of the activities themselves. These product documents usually serve as bases for planning subsequent activities. The logic diagrams and their supporting analyses are the bases for estimating costs and the schedule for the Waste Feed Delivery System and other elements of the TWR\&D mission. The development of technical baseline documents is scheduled and costed with the other logic activities.

\subsection{STRUCTURES, SYSTEMS, AND COMPONENTS}

Structures, systems, and components (SSC) for waste feed delivery are defined as the hardware and software required to process and transfer feed to the Private Contractor. Existing and future equipment used to transfer feed to the Private Contractor is identified as part of a waste feed delivery technical basis system description (HNF-1939, Waste Feed Delivery Technical Basis, Volume III, "Waste Feed Delivery System Description" [Rasmussen 1999]). This document identifies the specific tanks, associated piping and piping components, instrumentation and control systems, and ancillary equipment required to prepare and transfer the waste.

\subsubsection{System and Project Definition}

The Waste Feed Delivery System includes existing equipment as well as equipment to be provided by several projects. A number of the projects identified below predate the current TWR\&D mission. The objectives of each of these projects, however, are consistent with needs of the mission and the Waste Feed Delivery Program. The functional and technical requirements and products of each of these projects has been (or is being) evaluated and adjusted to support the current mission.

Top-level equipment and functional requirements for the overall DST system are defined in HNF-SD-WM-TRD-007 System Specification for the Double-Shell Tank System (Grenard et al. 1999). Specifications for the SST system and for individual components of the SST and DST systems are developed when needed. A future overarching functional requirements document includes process design requirements for existing and future Privatization Phase 1 Waste Feed Delivery System projects. After the functions and requirements and component specification documents are completed, the functional design criteria for the Waste Feed Delivery System projects are reviewed and revised as needed to ensure compliance.

The following projects provide equipment necessary to satisfy the Privatization Phase 1 requirements of the Waste Feed Delivery System:

- Project W-314: Tank Farm Restoration and Safe Operations, provides new transfer piping, valving, and master-pump shutdown equipment

- Project W-211: Initial Tank Retrieval System, provides new pumps (mixer pumps, decant pumps, slurry pumps, and supernate pumps); electrical system upgrades; instrumentation and control system upgrades; chemical addition system; and valving upgrades 
HNF-1901 Rev 1

- Project W-521: Waste Feed Delivery Systems, provides retrieval, transfer, and feed delivery systems to tie tank farms to the vitrification processing facility.

- Project W-151: AZ-101 Mixer Pumps, provides two mixer pumps, instrumentation and control upgrades, and electrical system upgrades in Tank 241-AZ-101.

The technical baseline documents for each of the projects above and for completed projects are identified in Appendix B. Additional projects are added to this document as they are defined.

\subsubsection{Project Records}

Project files are developed and maintained in accordance with project configuration management plans and document management plans. Documents associated with projects (e.g., drawings, calculations, correspondence, tests, and vendor information) are maintained as records and processed through the DIMCs.

The project files are complete, accurate, and made available to support projects that contribute to the Privatization Phase 1 and 2 Waste Feed Delivery System. Information resources are managed throughout the information lifecycle, including information creation, collection, processing, distribution, management, and disposition or retirement. Life-cycle activities are managed to make information useful, available, and effective in accomplishing project objectives.

The selection of controlled documents and information is in accordance with HNF-1900 (Vann et al. 1998) and implementing procedures.

\subsubsection{Reliability, Availability, and Maintainability Risk Evaluation}

A waste feed delivery reliability, availability, and maintainability (RAM) risk evaluation was documented for an HLW feed tank (241-AZ-101) and LAW feed tanks (241-AN-104 and 241AN-105) in HNF-2863, Rev. 0 (Papp 1998). This RAM analysis is updated for each tank and associated transfer system. The first RAM/risk evaluation was produced during fiscal year (FY) 1998. The document that contains the initial RAM/risk evaluation is being updated to reflect the fiscal year 1999 technical baseline with new and refined RAM/risk data. This RAM/risk evaluation is used to confirm or revise each tank's operating and maintenance concept and also may be used as a basis for revising design requirements and for developing the spare equipment list for the Waste Feed Delivery System.

\subsubsection{Spare Equipment List}

The RAM/risk evaluation for the Waste Feed Delivery System supports developing the waste feed delivery spare equipment list. Other bases for developing the list include vendor recommendations and reviews of historical maintenance records (available through the Hanford Site Job Control System [JCS]). 


\subsection{OPERATIONS, MAINTENANCE, AND SUPPORTING DOCUMENTS}

Operations, maintenance, and supporting technical baseline documents are those documents that are used to enable and control field activities. Related documents are described in the following subsections.

\subsubsection{Operations and Maintenance Concept}

A waste feed delivery technical-basis operations and maintenance concept technical baseline document is being generated during FY 1999 in concert with the waste feed delivery RAM/risk evaluation, process flowsheets (Orme 1999a, Orme 1999b, Orme 1999c), and system description (Rasmussen 1998). The operations and maintenance document is being used for developing waste feed delivery operation plans, maintenance plans, and operating and maintenance procedures. The operations and maintenance concept for the Waste Feed Delivery System is derived from current operating and maintenance practices and from new specification documents including HNF-SD-WM-TRD-007 (Grenard et al. 1999), which establishes functional and performance requirements for DST equipment systems.

\subsubsection{Permits and Safety Authorizations}

Permitting activities related to the RPP are identified in HNF-1773, River Protection Project Environmental Program Plan (Allen 1999), which addresses environmental policy requirements; permit and compliance responsibilities; planning; reports, notifications, and records; verification corrective actions; and preliminary permit modification schedules. The range of environmental actions, including required permits and other agency approvals that may affect waste feed delivery activities in the RPP, are described in HNF-2401, Waste Feed Delivery Environmental Permits and Approvals Plan (Papp et al. 1998). The current list of environmental permits and related documentation can be found in HNF-4474, RPP Environmental Permits and Related Documentation (Dexter 1999). The safety Authorization Basis under which the RPP currently operates is found in HNF-SD-WM-BIO-001, Tank Waste Remediation System Basis for Interim Operation (BIO) (FDH 1999). That document is being amended to allow for Privatization Phase 1 operations and related field activities.

\subsubsection{Process Limits}

Waste feed delivery process limits include operating limits and technical safety requirements (TSR). Operating limits are imposed to ensure that processing is at an acceptably low risk of failure to deliver on-specification waste to the Private Contractor on time. The TSRs are used to ensure the safe operation of tank farm facilities. These requirements continue to evolve as tank farm missions change. The current TSRs for the RPP are identified in HNF-SD-WM-TSR-006, Tank Waste Remediation System Technical Safety Requirements (LMHC 1999d). That document defines acceptable conditions, safe boundaries, bases thereof, and management or administrative controls required to ensure safe operation. The TSRs are based on the preventive and mitigative features determined in the BIO to be essential (FDH 1999). The TSRs are augmented with tankspecific limits and guidance designed to ensure adequate processing and maintenance rates. The 
limits and guidance are derived from the tank-specific RAM/risk evaluation and latitudes allowed by the waste feed delivery operations and maintenance concept.

\subsubsection{Safety Equipment List}

The safety equipment list for the RPP is identified in HNF-SD-WM-SEL-040 (Jensen 1998), which identifies the SSCs important to operations and maintenance safety and provides the RPP with the requirements to support occurrence reporting. The safety classifications provided in the document support the BIO (FDH 1999). The barriers and administrative controls in the BIO help to prevent or mitigate the accidents analyzed and are the bases for the selected safety classifications described. HNF-SD-WM-SEL-040 (Jensen 1998) is being amended before operation of the Waste Feed Delivery System begins, to incorporate new safety class equipment installed during construction projects. HNF-SD-WM-SEL-040 (Jensen 1998) and the spare equipment list are parts of the master equipment list.

\subsubsection{Operations and Maintenance Environmental, Safety, and Health Plans}

The operations and maintenance environment, safety, and health (ES\&H) plans are located in HNF-1773, River Protection Project Environmental Program Plan (Allen 1999) and in HNF-SD-WM-HSP-002, Tank Farm Health and Safety Plan (Huckfeldt 1999). The Health and Safety Plan applies to the conduct of operations and work activities in the Hanford Site 200 Area tank farms and is used to minimize health and safety risks to workers and other onsite personnel. The Health and Safety Plan establishes requirements, provides general guidelines, and conveys tank farm- and facility-specific hazard information. Environmental requirements are identified in HNF-1773 (Allen 1999).

\subsubsection{Operations and Maintenance Procedures}

Operations and maintenance procedures are being developed for the Waste Feed Delivery System. Procedure development occurs after the project designs have been completed. Procedures are written in accordance with HNF-IP-0842, RPP Administration, Volume I, "Administration," Section 2.1, "Procedure Development and Maintenance" (LMHC 1999c).

\subsubsection{Training Certification}

Training and certification occur after the specific procedures for operation and maintenance of the Waste Feed Delivery System are in place. Shift supervisors, operating engineers, operators, craftsmen; and technicians are trained to the procedures. Management, engineering, and other professional staff receive specialized professional training and certification as necessary to ensure proficiency. Training of personnel involved in tank farm operations and maintenance is planned to be accomplished using the existing training infrastructure. The training infrastructure is defined in HNF-IP-0842, RPP Administration, Volume III, "Training" (LMHC 1999c). 
HNF-1901 Rev 1

\subsubsection{Operations and Maintenance Records}

Operations and maintenance records include calibration, process performance, and system surveillance documents. As the Waste Feed Delivery System is defined, operations and maintenance procedures are written to govern record-keeping activities. The records are developed, collected, and maintained consistent with the project records procedures discussed in Section 3.4.2.

\subsection{SECONDARY WASTE DEFINITION}

Operation of the Waste Feed Delivery System results in the generation of secondary wastes. Management of secondary waste is addressed in Section 7.0 of this document.

\subsection{PROGRAMMATIC INTERFACES}

The ICDs define the interfaces between the ORP/RPP team and the Private Contractor. Specifically the ICDs define materials, utilities, and services to be provided to the Private Contractor and define products and waste that are returned to the ORP/RPP team. These interface documents are described in Section 5.0 of this document.

The Waste Feed Delivery System is supported by utilities and other infrastructure services provided by DYN. An agreement in principle between the RPP and DYN (LMHC 1999a) was issued to ensure delivery of the required services (see Section 8.0 of this document). A similar agreement between the RPP and WMH was issued (LMHC 1999b) to ensure that the Waste Feed Delivery System is supported with adequate secondary waste management and laboratory analytical services (see Section 7.0 of this document).

The Waste Feed Delivery System may be impacted by two RPP programs: the Tank Waste Storage Program and the Tank Waste Characterization Program. The Tank Waste Storage Program is responsible for managing tank wastes until they are retrieved and processed. Tank waste management includes transferring wastes between tanks using tanks, pipelines, and other equipment that also are used in the Waste Feed Delivery System. The Tank Waste Characterization Program is responsible for sampling and characterizing tank wastes. Sampling and characterization efforts in support of waste retrieval and feed delivery operations are consistent with the activities and practices discussed in Section 3.1 of this document. 


\subsection{INFRASTRUCTURE SUPPORT}

The Infrastructure Program is responsible for ensuring that infrastructure services are provided to the Privatization Contractor, BNFL, during construction, startup, and production of its waste treatment facility in support of the Privatization Phase 1B TWR\&D mission. Project W-519 provides access roads, land for siting the BNFL waste treatment facility and support equipment, raw and potable water, electricity, and transfer pipelines for liquid effluents. On completion of Project W-519, the Infrastructure Program, DYN, and WMH ensure that infrastructure services (i.e., roads, raw and potable water, electricity), radioactive-solid-waste disposal, and liquideffluent transfers (i.e., nonradioactive/nondangerous and radioactive/dangerous) continue to support BNFL through the duration of the Phase 1B mission.

The primary source documents regarding the scope and basis for infrastructure support include: HNF-1882, River Protection Project Tank Waste Retrieval and Disposal Mission Infrastructure Plan (Freeman-Pollard and Root 1999); BNFL-5193-ID-01, Interface Control Document Between DOE and BNFL Inc.for Raw Water (BNFL 1998a); BNFL-5193-ID-02, Interface Control Document Between DOE and BNFL Inc. for Potable Water (BNFL 1998b); BNFL-5193-ID-03, Interface Control Document Between DOE and BNFL Inc. for Radioactive Solid Waste (BNFL 1998c); BNFL-5193-ID-05, Interface Control Document Between DOE and BNFL Inc.for Non-Radioactive, Non-Dangerous Liquid Effluents (BNFL 1998d); BNFL-5193-ID-06, Interface Control Document Between DOE and BNFL Inc. for Radioactive, Dangerous Liquid Effluents (BNFL 1998e); BNFL-5193-ID-09, Interface Control Document Between DOE and BNFL Inc. for Land for Siting (BNFL 1998f); and BNFL-5193-ID-11, Interface Control Document Between DOE and BNFL Inc. for Electricity (BNFL 1998h).

This section briefly summarizes the scope of the Infrastructure Program and identifies technical baseline documents that support BNFL construction, startup, and production activities throughout the Privatization Phase 1B mission. Table 3 lists the technical baseline documents identified to date for the Infrastructure Program, along with summaries of the source information for each listed document. Table 4 in Chapter 5.0 and Appendix D summarize the interface control documents. A brief summary of each listed document and pertinent information is contained in Appendix C.

\subsection{PRIMARY WASTE AND PRODUCT DEFINITIONS}

The ORP/RPP team and BNFL ICDs, the characterization requirements of Standard 3 (Products and Secondary Wastes Plans), and the privatization contract (RL 1998) serve as the basis for defining the waste products expected from BNFL.

\subsection{PROCESS DEFINITION}

During Privatization Phase 1B, BNFL constructs, starts up, and commences operation of its waste treatment facility. Project W-519 was formed to perform infrastructure construction activities (e.g., access road development, water pipelines upgrades) to accommodate Phase $1 \mathrm{~B}$ infrastructure needs for BNFL. Upon the completion of Project W-519 construction activities, 
the infrastructure Program ensures that infrastructure needs for BNFL are met during the Phase $1 \mathrm{~B}$ mission.

Table 3. Infrastructure Support Documents and Designated Source Information.

\begin{tabular}{|c|c|c|c|}
\hline Document & $\begin{array}{l}\text { Maintained } \\
\text { current? }\end{array}$ & $\begin{array}{l}\text { Appendix } \\
\text { number }\end{array}$ & Source information \\
\hline $\begin{array}{l}\text { WHC-SD-WM-TI-750, } \\
\text { Alternative Generation and } \\
\text { Analysis for Phase } 1 \\
\text { Privatization Transfer System } \\
\text { Needs (Galbraith 1996) }\end{array}$ & No & C. 1 & $\begin{array}{l}\text { Piping system upgrades for AN, } \\
\text { AW, and AP Tank Farms }\end{array}$ \\
\hline $\begin{array}{l}\text { HNF-SD-WM-TI-800, } \\
\text { Decision Document: Phase } 1 \\
\text { Intermediate Waste Feed } \\
\text { Staging System Design } \\
\text { Requirements (Galbraith and } \\
\text { Daling 1997) }\end{array}$ & No & C. 2 & Intermediate feed staging \\
\hline $\begin{array}{l}\text { Project W-519 technical } \\
\text { baseline documents }\end{array}$ & Yes & C.3 & $\begin{array}{l}\text { Technical baseline documents } \\
\text { related to the W-519 Project, } \\
\text { TWRS Privatization Phase 1, } \\
\text { Infrastructure Support }\end{array}$ \\
\hline
\end{tabular}

TWRS
TWann

To accomplish this, an agreement in principle was signed between LMHC and DYN for utility support (i.e., road maintenance, raw and potable water services, and electrical services) during BNFL's facility construction, startup, and operation activities and is updated annually (LMHC 1999a).

An agreement in principle was signed between $\mathrm{LMHC}$ and $\mathrm{WMH}$ for radioactive solid waste disposal and effluent (radioactive/dangerous and nonradioactive/nondangerous) transfer support during BNFL's facility construction, startup, and operation activities and is updated annually (LMHC 1999b).

The infrastructure support services that BNFL requires during completion of the Privatization Phase $1 \mathrm{~B}$ mission are as follows. 
HNF-1901 Rev 1

\subsubsection{Land for Siting}

BNFL-5193-10-09, Interface Control Document Between DOE and BNFL Inc. for Land for Siting (BNFL 1998f): The ORP/RPP team is transferring approximately 60 acres (see Section J, Attachment 3 of RL [1998]) under a no-cost lease to BNFL for construction and operations activities.

\subsubsection{Roads}

BNFL-5193-10-12, Interface Control Document Between DOE and BNFL Inc. for Roads and Rails (BNFL 1998i): The ORP/RPP team provides and maintains new and existing roads between the BNFL site boundary and existing Hanford Site roads.

\subsubsection{Raw and Potable Water}

BNFL-5193-10-01, Interface Control Document Between DOE and BNFL Inc. for Raw Water (BNFL 1998a): BNFL estimates that an average raw water flow rate of 760 liters per minute $(\mathrm{L} / \mathrm{min})$ is required for operation of its LAW/HLW treatment facility. BNFL also estimates that an average raw water flow rate of $9,450 \mathrm{~L} / \mathrm{min}$ is needed for fire protection systems.

BNFL-5193-10-02, Interface Control Document Between DOE and BNFL Inc. for Potable Water (BNFL 1998b): BNFL estimates that an average potable water flow rate of $200 \mathrm{~L} / \mathrm{min}$ is required for domestic use at its LAW/HLW treatment facility.

\subsubsection{Electricity}

BNFL-5193-10-11, Interface Control Document Between DOE and BNFL Inc. for Electricity (BNFL 1998h): The ORP/RPP team is delivering up to $7 \mathrm{MW}$ of $13.8 \mathrm{kV} 60 \mathrm{~Hz}$ three-phase power for the construction of the BNFL facilities and $33 \mathrm{MW}$ of $13.8 \mathrm{kV} 60 \mathrm{~Hz}$ three-phase power for the testing, startup, and operation of the BNFL waste treatment facility.

\subsubsection{Effluent Waste Transfer}

BNFL-5193-10-05, Interface Control Document Between DOE and BNFL Inc.for NonRadioactive, Non-Dangerous Liquid Effluents (BNFL 1998d): The ORP/RPP team provides and maintains a transfer pipeline from BNFL to the Treated Effluent Disposal Facility (TEDF). BNFL estimates that up to $300,000 \mathrm{~m}^{3} / \mathrm{yr}$ of nonradioactive, nondangerous liquid effluents (which corresponds to an average flow rate of $570 \mathrm{~L} / \mathrm{min}$ ) will be transferred to the TEDF. The maximum instantaneous discharge rate that the TEDF can expect to receive is $900 \mathrm{~L} / \mathrm{min}$.

BNFL-5193-10-06, Interface Control Document Between DOE and BNFL Inc. for Radioactive, Dangerous Liquid Effluents (BNFL 1998e): The ORP/RPP team provides and maintains a Resource Conservation and Recovery Act of 1976- (RCRA-) compliant transfer pipeline from BNFL to the Liquid Effluent Retention Facility/Effluent Treatment Facility (LERF/ETF). BNFL 
estimates that up to $100,000 \mathrm{~m}^{3} / \mathrm{yr}$ of radioactive, dangerous liquid effluents (which corresponds to an average flow rate of $190 \mathrm{~L} / \mathrm{min}$ ) will be transferred to the LERF/ETF.

\subsubsection{Radioactive Solid Waste}

BNFL-5193-10-03, Interface Control Document Between DOE and BNFL Inc. for Radioactive Solid Waste (BNFL 1998c): The ORP/RPP team reviews, modifies, and maintains the Hanford Site Solid Waste Acceptance Criteria for acceptance of certified radioactive solid waste from BNFL. The ORP/RPP team also provides transportation services and vehicles for transporting radioactive solid waste from BNFL's facility to the disposal facility.

\subsection{MISSION PLANNING}

Activities required to achieve the objectives of the Infrastructure Program are included in the infrastructure Level 1 logics and in HNF-SP-1230 (Lenseigne 1998). These activities are further defined in the PHMC team and BNFL ICDs and in the TWRS Privatization Contract (RL 1998). Also, DOE guidance for developing multiyear work plans addresses which technical baseline documents are produced, used, revised, or deleted.

\subsection{STRUCTURES, SYSTEMS AND COMPONENTS}

The SSCs currently in place are documented in agreements in principle (LMHC 1999a, 1999b), the Project W-519 design drawings and specifications, and other project-specific documents. Hanford Site as-built drawings affected by Project W-519 and BNFL construction activities are being updated to reflect physical interfaces and equipment configuration changes. All documents related to SSCs are reviewed periodically against the PHMC team and BNFL ICDs. Significant changes are incorporated into the RPP technical baseline after they are validated. The RPP also documents and includes in the RPP technical baseline any significant TWRS Privatization Contact (RL 1998) modifications that impact Infrastructure Program and Project W-519 support activities.

In addition, the RPP is responsible for the design and construction of a waste transfer pipeline from the RPP LAW/HLW staging tanks to the BNFL LAW/HLW staging tanks. BNFL provides and installs the necessary tank, ancillary equipment, monitoring hardware (e.g., ventilation, emissions), and control systems to receive and transfer waste from the BNFL staging tanks to its facilities. The design of the RPP LAW/HLW transfer pipeline, as well as the location of the LAW staging tank(s), is being developed.

\subsubsection{Systems and Project Definition}

The infrastructure program provides utility and electrical support to BNFL via existing or new infrastructure systems. Upgrade of the existing Hanford Site infrastructure systems is being performed by Project W-519. Because the objectives of Project W-519 are consistent with the needs of the RPP privatization mission and the Infrastructure Program, the functional and 
technical requirements and products for Project W-519 are evaluated and adjusted, if necessary, to support the RPP privatization mission and Infrastructure Program objectives.

\subsubsection{Project Records}

Project files are developed and maintained in accordance with project configuration management plans and document management plans. Documents associated with Project W-519

(e.g., drawings, calculations, correspondence, tests, vendor information) are maintained as records and processed through the DIMCs.

The project files are complete, accurate, and made available to support activities that contribute to the Privatization Phase 1 and Phase 2 Waste Feed Delivery System. Information resources are managed throughout the information life cycle, including information creation, collection, processing, distribution, management, and disposition or retirement. Life-cycle activities are managed to make information useful, available, and effective in accomplishing project objectives.

The selection of controlled documents and information is in accordance with HNF-1900 (Vann et al. 1998) and implementing procedures.

\subsubsection{Engineering Studies}

A RAM analysis/risk evaluation is being generated for the water, electrical, and effluent transfer systems to confirm or revise operating and maintenance concepts. The RAM analysis/risk evaluations also serve as a basis for revising Hanford Site infrastructure support requirements for the RPP Privatization Phase 1 mission.

\subsubsection{Spare Equipment List}

The RAM analysis/risk evaluations serve as a basis for developing a spare equipment/parts list. Other information that is used to develop the spare equipment/parts list includes vendor recommendations and reviews of historical maintenance records (available through the Hanford Site JCS).

\subsection{OPERATIONS, MAINTENANCE, AND SUPPORTING DOCUMENTS}

Operations, maintenance, and supporting documents are used to enable and control field activities. The Infrastructure Program has initiated Hanford Site infrastructure upgrade (i.e., design and construction) activities in support of the TWRS Privatization Contract (RL 1998). Thus, many of the following sections are being developed and are intended as placeholders for future discussions and amendments to this document. 


\section{HNF-1901 Rev 1}

\subsubsection{Operations and Maintenance Concept}

Operations and maintenance concepts for water, electrical, roads, and liquid effluent/solid-waste disposal are developed from a combination of sources including derivation from existing practices or previous concepts, adaptation of new procedures, ICDs, memoranda of understanding, and agreements in principle. Documents specific to the operation and maintenance of water, electrical, roads, and liquid effluent/solid-waste-disposal systems are added to and controlled as a part of the technical baseline as they are completed.

\subsubsection{Permits and Safety Authorizations}

Environmental permit planning documents are prepared or revised for the water, electrical, roads, and liquid effluent/solid-waste-disposal activities. In addition, the following Authorization Basis documents are being amended, as needed, to address interfaces with ETF, LERF, TEDF, and BNFL:

- HNF-SD-ETF-ASA-001, 200 Area ETF Auditable Safety Analysis Report (Le 1998)

- WHC-SD-C018H-HC-002, Hazard Categorization Report for the 200 Area Effluent Treatment Facility (Bourger 1994)

- HNF-SD-WM-SAD-040, Liquid Effluent Retention Facility Final Hazard Category Determination (Galioto 1997b)

- HNF-SD-LEF-ASA-002, 242AL Liquid Effluent Retention Facility Auditable Safety Analysis (Galioto 1997a)

- WHC-SD-WM-SAR-023, 242-A Evaporator/Crystallizer Safety Analysis Report (Lavender 1992).

Finally, all governing procedures (e.g., Radionuclide Inventory Control) are being revised as necessary.

\subsubsection{Process Limits}

Initial infrastructure support requirements have been established in the ICDs for water, electrical, roads, and liquid effluent/solid-waste disposal. However, these initial requirements may be revised per the privatization contract for Phase 1B.

\subsubsection{Safety Equipment List}

The safety equipment list for the RPP is identified in HNF-SD-WM-SEL-040 (Jensen 1998). This document identifies the operating and maintenance SSCs important to safety and provides the requirements to support occurrence-reporting activities for RPP operations. The facility safety equipment list is augmented by the operator(s) of the ETF, LERF, TEDF, and solid-waste- 
disposal facilities, as required in the WMH Authorization Basis (REF). HNF-SD-WM-SEL-040 is updated to cover facilities that support the transport and disposition of products delivered by BNFL.

\subsubsection{Operations and Maintenance Environmental, Safety, and Health and Quality Assurance Plans}

The Infrastructure Program performs ES\&H and quality assurance activities to ensure that water, electricity, liquid effluent, and solid-waste-disposal activities are carried out in compliance with Federal, state, and local regulations; laws, and standards for the protection of the environment and the safety and health of the public and employees. Activities conducted in the RPP are in accordance with HNF-1773 (Allen 1999) and RPP implementing procedures.

\subsubsection{Operations and Maintenance Procedures}

The Infrastructure Program, DYN, and WMH are developing operations and maintenance procedures for the water, electrical, roads, liquid effluent, and solid waste disposal systems, as needed. Procedure development occurs after Project W-519 has been completed and accepted by the RPP. Operations and maintenance procedures are considered technical baseline documents.

\subsubsection{Training Certifications}

Training and certification occurs after the specific procedures for operation and maintenance of the water, electrical, liquid effluent, and solid-waste-disposal systems are in place. Shift supervisors, operating engineers, operators, craftsmen, and technicians are trained to the procedures. Management, engineering, and other professional staff may receive specific professional training and certification as necessary to ensure proficiency. Personnel involved in liquid effluent and solid-waste-disposal systems handling and disposition are being trained within the existing training infrastructure. Training certifications are considered technical baseline documents. Hanford Atomic Metals Trade Council personnel are trained and certified by BNFL.

\subsubsection{Operations and Maintenance Records}

Operations and maintenance records include, as a minimum, calibration, process performance, and system surveillance documents. The Infrastructure Program, DYN, and WMH develop procedures to govern record-keeping activities associated with water, electrical, roads, liquid effluent, and solid-waste-disposal systems. These records are considered to be technical baseline documents, and they are developed, collected, and maintained consistent with the project records procedures discussed in Section 6.4.2 of this document. 


\subsection{SECONDARY WASTE DEFINITION}

The secondary wastes expected under this program are RPP privatization operation in nature and are produced by BNFL. Other secondary waste includes relatively small volumes of personal protective equipment, high-efficiency particulate air filters, and other material generated as a result of routine facility operations and Project W-519.

\subsection{PROGRAMMATIC INTERFACES}

The Infrastructure Program management plan (HNF-1882, Freeman-Pollard and Root 1999) describes interactions among and responsibilities of the ORP/RPP team, the engineer/constructor, BNFL, and permitting authorities such as the Washington State Department of Ecology (Ecology).

An integrated product and process development (IPPD) team has been established to define responsibilities and resolve issues between the ORP/RPP team and BNFL. The IPPD team is conducted in accordance with BNFL ICDs and the TWRS Privatization Contract (RL 1998).

The Infrastructure Program, DYN, and WMH provide utilities and other infrastructure services to BNFL. An agreement in principle between LMHC and DYN was issued to ensure delivery of the required services (i.e., water, roads, and electricity) during BNFL construction, startup, and production activities (LMHC 1999a). A similar interface agreement between LMHC and WMH was prepared to ensure that liquid effluent and solid-waste disposal are supported with adequate facilities, operations, management, laboratory analytical services, and other required support (see Section 7.0 of this document) (LMHC 1999b). 
HNF-1901 Rev 1

\subsection{PRIVATIZATION CONTRACT INTERFACES}

In accordance with the TWRS Privatization Contract (RL 1998), BNFL provides system capacity for waste treatment services for minimum order quantities of 6,000 units of LAW and 600 canisters of HLW glass. In a given year, BNFL can process up to 1,100 units of LAW and produce up to 1.20 canisters of.HLW glass. Units of LAW are approximately equal to metric tons of sodium.

The following services are provided by the Private Contractor:

- Receive batches of the three LAW waste envelopes (A, B, and C)

- Receive batches of HLW feed (envelope D) into a Private Contractor-provided transfer system, tank, and facility

- Determine the degree of entrained solids, ${ }^{137} \mathrm{Cs},{ }^{99} \mathrm{~T},{ }^{90} \mathrm{Sr}$, and TRU removal required to comply with contractual requirements and separate the waste into LAW and HLW fractions

- Treat and immobilize the LAW fraction and provide the final ILAW for return to the RPP

- Treat and immobilize the HLW fraction and provide it to RPP for storage and ultimate disposal

- Protect materials from diversion, and the facilities and materials from sabotage or other acts that can result in widespread exposure of workers and the public

- Deactivate Private Contractor facilities at the completion of waste treatment services.

Contractual expectations of the government (and hence the ORP/RPP team) and the Private Contractor are largely driven by interface descriptions identified in the privatization contract. Three interface descriptions identify that the Private Contractor is fully responsible for its generated dangerous waste (Interface Description 4), nondangerous solid wastes (Interface Description 8), and liquid sanitary waste (Interface Description 9). The interface descriptions are part of the privatization contract and, as such, are not considered technical baseline documents.

Twenty interface descriptions are further defined through privatization ICDs. Two of these interfaces were eliminated through the results of system optimization studies. The remaining 18 privatization ICDs discussed in this section are grouped into one of three categories for discussion purposes: (1) input (i.e., waste feed), (2) supporting system (i.e., infrastructure support-related), and (3) output (i.e., Private Contractor-supplied products).

The ICD subjects and categories are provided in Table 4 . Table 4 also indicates the contractual performance agreement specifications as applicable. Table 5 provides the list of each ICD along with each document's source information and the applicable location in Appendix D. 
Table 4. Interface Categories and Requirements of Privatization Contract.

\begin{tabular}{|c|c|c|c|c|c|}
\hline \multirow{2}{*}{ no. } & \multirow{2}{*}{ ICD subject } & \multicolumn{3}{|c|}{ ICD category } & \multirow{2}{*}{$\begin{array}{l}\text { Privatization contractor } \\
\text { performance agreement } \\
\text { contract } \mathrm{t}^{\mathrm{b}} \text { specification }\end{array}$} \\
\hline & & Input & Support & Output & \\
\hline 1 & Raw water & & - & & N/A \\
\hline 2 & Potable water & & $\bullet$ & & N/A \\
\hline 3 & Radioactive solid waste & & & $\bullet$ & N/A \\
\hline 5 & $\begin{array}{l}\text { Nonradioactive, nondangerous } \\
\text { liquid effluent }\end{array}$ & & & - & N/A \\
\hline 6 & $\begin{array}{l}\text { Radioactive, dangerous liquid } \\
\text { effluent }\end{array}$ & & & - & N/A \\
\hline 9 & Land for siting & & - & & N/A \\
\hline 10 & Deactivated facility and site & . & & - & N/A \\
\hline 11 & Electricity & & $\cdot$ & & N/A \\
\hline 12 & Roads and rails & & - & & N/A \\
\hline 14 & Immobilized high-level waste & & & $\cdot$ & Spec. 1 \\
\hline 15 & Immobilized low-activity waste & & & $\bullet$ & Spec. 2 \\
\hline 16 & Entrained solids & . & & $\cdot$ & Specs. 3,9 \\
\hline 19 & Low-activity waste feed & - & & & Spec. 7 \\
\hline 20 & High-level waste feed & $\bullet$ & & & Spec. 8 \\
\hline 22 & Air emissions & & • & & N/A \\
\hline 23 & Waste treatability samples & & $\cdot$ & & N/A \\
\hline 25 & Emergency response & & $\bullet$ & & N/A \\
\hline 26 & Permits & & - & & N/A \\
\hline
\end{tabular}

${ }^{a} \mathrm{ICDs}$ No. 4, 7, 8, 13, 17, and 18 do not exist.

${ }^{b}$ RL, 1998, TWRS Privatization Contract, DE-AC06-96RL13308, U.S. Department of Energy, Richland Operations Office, Richland, Washington.

ICD = interface control document.

$\mathrm{N} / \mathrm{A}=$ not applicable. 
Table 5. Privatization Interface Control Documents and Designated Source Information. (3 sheets)

\begin{tabular}{|c|c|c|c|c|}
\hline ICD & ICD title & $\begin{array}{l}\text { Maintained } \\
\text { current? }\end{array}$ & $\begin{array}{l}\text { Appendix } \\
\text { number }\end{array}$ & Source information \\
\hline 1 & $\begin{array}{l}\text { BNFL-5193-10-01, Interface } \\
\text { Control Document Between DOE } \\
\text { and BNFL Inc. - Raw Water } \\
\text { (BNFL 1998a) }\end{array}$ & Yes & D.1 & $\begin{array}{l}\text { Establishes interfaces with } \\
\text { Private Contractor for raw } \\
\text { water delivery and use. }\end{array}$ \\
\hline 2 & $\begin{array}{l}\text { BNFL-5193-10-02, Interface } \\
\text { Control Document Between DOE } \\
\text { and BNFL Inc. for Potable Water } \\
\text { (BNFL 1998b) }\end{array}$ & Yes & D. 2 & $\begin{array}{l}\text { Establishes interfaces with } \\
\text { Private Contractor for the } \\
\text { delivery and use of potable } \\
\text { water. }\end{array}$ \\
\hline 3 & $\begin{array}{l}\text { BNFL-5193-10-03, Interface } \\
\text { Control Document Between DOE } \\
\text { and BNFL Inc. for Radioactive } \\
\text { Solid Waste (BNFL 1998c) }\end{array}$ & Yes & D. 3 & $\begin{array}{l}\text { Establishes interfaces with } \\
\text { Private Contractor for the } \\
\text { handling and managing of } \\
\text { radioactive solid waste. }\end{array}$ \\
\hline 5 & $\begin{array}{l}\text { BNFL-5193-10-05, Interface } \\
\text { Control Document Between DOE } \\
\text { and BNFL Inc. for Non- } \\
\text { Radioactive, Non-Dangerous } \\
\text { Liquid Effluents (BNFL 1998d) }\end{array}$ & Yes & D. 4 & $\begin{array}{l}\text { Establishes interfaces with } \\
\text { Private Contractor for the } \\
\text { handling and managing of } \\
\text { nonradioactive, } \\
\text { nondangerous liquid } \\
\text { effluents. }\end{array}$ \\
\hline 6 & $\begin{array}{l}\text { BNFL-5193-10-06, Interface } \\
\text { Control Document Between DOE } \\
\text { and BNFL Inc. for Radioactive, } \\
\text { Dangerous Liquid Effluents } \\
\text { (BNFL 1998e) }\end{array}$ & Yes & D.5 & $\begin{array}{l}\text { Establishes interfaces with } \\
\text { Private Contractor for the } \\
\text { handling and managing of } \\
\text { radioactive, dangerous } \\
\text { liquid effluents. }\end{array}$ \\
\hline 9 & $\begin{array}{l}\text { BNFL-5193-10-09, Interface } \\
\text { Control Document Between DOE } \\
\text { and BNFL Inc. for Land for Siting } \\
\text { (BNFL 1998f) }\end{array}$ & Yes & D. 6 & $\begin{array}{l}\text { Establishes interfaces with } \\
\text { Private Contractor for land } \\
\text { for siting Privatization } \\
\text { Phase } 1 .\end{array}$ \\
\hline 10 & $\begin{array}{l}\text { BNFL-5193-10-10Interface } \\
\text { Control Document Between DOE } \\
\text { and BNFL Inc. for Deactivated } \\
\text { Facility and Site (BNFL 1998g) }\end{array}$ & Yes & D.7 & $\begin{array}{l}\text { Establishes interfaces with } \\
\text { Private Contractor for the } \\
\text { facility deactivation and site } \\
\text { turnover to DOE following } \\
\text { completion of Privatization } \\
\text { Phase } 1 \text { activities. }\end{array}$ \\
\hline
\end{tabular}


Table 5. Privatization Interface Control Documents and

Designated Source Information. (3 sheets)

\begin{tabular}{|c|c|c|c|c|}
\hline $\begin{array}{l}\text { ICD } \\
\text { no. }\end{array}$ & ICD title & $\begin{array}{c}\text { Maintained } \\
\text { current? }\end{array}$ & $\begin{array}{l}\text { Appendix } \\
\text { number }\end{array}$ & Source information \\
\hline 11 & $\begin{array}{l}\text { BNF-5193-10-11, Interface } \\
\text { Control Document Between DOE } \\
\text { and BNFL Inc. for Electricity } \\
\text { (BNFL 1998h) }\end{array}$ & Yes & D. 8 & $\begin{array}{l}\text { Establishes interfaces with } \\
\text { Private Contractor with } \\
\text { respect to electricity } \\
\text { delivery to Private } \\
\text { Contractor facilities during } \\
\text { Privatization Phase } 1 \\
\text { activities. }\end{array}$ \\
\hline 12 & $\begin{array}{l}\text { BNF-5193-10-12, Interface } \\
\text { Controi Document Between DOE } \\
\text { and BNFL Inc. for Roads and } \\
\text { Rails (BNFL 1998i) }\end{array}$ & Yes & D.9 & $\begin{array}{l}\text { Establishes interfaces with } \\
\text { Private Contractor for road } \\
\text { use during Privatization } \\
\text { Phase } 1 \text { activities and } \\
\text { establishes that there is no } \\
\text { direct rail. }\end{array}$ \\
\hline 14 & $\begin{array}{l}\text { BNF-5193-10-14, Interface } \\
\text { Control Document Between DOE } \\
\text { and BNFL Inc. for Immobilized } \\
\text { High-Level Waste Product } \\
\text { (BNFL 1998j) }\end{array}$ & Yes & D.11 & $\begin{array}{l}\text { Establishes interfaces with } \\
\text { Private Contractor for the } \\
\text { acceptance and delivery of } \\
\text { the immobilized high-level } \\
\text { waste product by and to the } \\
\text { ORP/RPP team during } \\
\text { Privatization Phase } 1 \\
\text { activities. }\end{array}$ \\
\hline 15 & $\begin{array}{l}\text { BNF-5193-10-15, Interface } \\
\text { Control Document Between DOE } \\
\text { and BNFL Inc. for Immobilized } \\
\text { Low-Activity Waste Product } \\
\text { (BNFL 1998k) }\end{array}$ & Yes & D. 12 & $\begin{array}{l}\text { Establishes interfaces with } \\
\text { Private Contractor for the } \\
\text { acceptance and delivery of } \\
\text { the immobilized low- } \\
\text { activity waste product by } \\
\text { and to the ORP/RPP team } \\
\text { during Privatization Phase } 1 \\
\text { activities. }\end{array}$ \\
\hline 16 & $\begin{array}{l}\text { BNF-5193-10-16, Interface } \\
\text { Control Document Between DOE } \\
\text { and BNFL Inc. for Entrained } \\
\text { Solids (BNFL 19981) }\end{array}$ & Yes & D. 13 & $\begin{array}{l}\text { Establishes interfaces with } \\
\text { Private Contractor for the } \\
\text { return of }{ }^{90} \mathrm{Sr} / \mathrm{TRU} / \\
\text { entrained solids to the } \\
\text { ORP/RPP team from the } \\
\text { Private Contractor during } \\
\text { Privatization Phase } 1 \\
\text { activities. }\end{array}$ \\
\hline
\end{tabular}


Table 5. Privatization Interface Control Documents and

Designated Source Information. (3 sheets)

\begin{tabular}{|c|c|c|c|c|}
\hline $\begin{array}{l}\text { ICD } \\
\text { no }\end{array}$ & ICD title & $\begin{array}{l}\text { Maintained } \\
\text { current? }\end{array}$ & $\begin{array}{l}\text { Appendix } \\
\text { number }\end{array}$ & Source information \\
\hline 19. & $\begin{array}{l}\text { BNF-5193-10-19, Interface } \\
\text { Control Document Between DOE } \\
\text { and BNFL Inc. for Low-Activity } \\
\text { Waste Feed (BNFL 1998m) }\end{array}$ & Yes & D. 16 & $\begin{array}{l}\text { Establishes interfaces with } \\
\text { Private Contractor for the } \\
\text { delivery of the low-activity } \\
\text { waste feed. }\end{array}$ \\
\hline 20 & $\begin{array}{l}\text { BNF-5193-10-20, Interface } \\
\text { Control Document Between DOE } \\
\text { and BNFL Inc. for High-Level } \\
\text { Waste Feed (BNFL 1998n) }\end{array}$ & Yes & D. 17 & $\begin{array}{l}\text { Establishes interfaces with } \\
\text { Private Contractor for the } \\
\text { delivery of the high-level } \\
\text { waste feed. }\end{array}$ \\
\hline 22 & $\begin{array}{l}\text { BNF-5193-10-22, Interface } \\
\text { Control Document Between DOE } \\
\text { and BNFL Inc. for Air Emissions } \\
\text { (BNFL 1998o) }\end{array}$ & Yes & D. 19 & $\begin{array}{l}\text { Establishes interfaces with } \\
\text { Private Contractor for air } \\
\text { emissions regulatory and } \\
\text { reporting requirements }\end{array}$ \\
\hline 23 & $\begin{array}{l}\text { BNF-5193-10-23, Interface } \\
\text { Control Document Between DOE } \\
\text { and BNFL Inc. for. Waste } \\
\text { Treatability Samples } \\
\text { (BNFL 1998p) }\end{array}$ & Yes & D. 20 & $\begin{array}{l}\text { Establishes interfaces with } \\
\text { Private Contractor for waste } \\
\text { treatability sample delivery } \\
\text { and residue return. }\end{array}$ \\
\hline 25 & $\begin{array}{l}\text { BNF-5193-10-25, Interface } \\
\text { Control Document Between DOE } \\
\text { and BNFL Inc. for Emergency } \\
\text { Response (BNFL 1998q) }\end{array}$ & Yes & D. 21 & $\begin{array}{l}\text { Establishes interfaces with } \\
\text { Private Contractor for } \\
\text { emergency planning, } \\
\text { notification, preparedness, } \\
\text { response, and reporting. }\end{array}$ \\
\hline 26 & $\begin{array}{l}\text { BNF-5193-10-26, Interface } \\
\text { Control Document Between DOE } \\
\text { and BNFL Inc. for Permits } \\
\text { (BNFL 1998r) }\end{array}$ & Yes & D.22 & $\begin{array}{l}\text { Establishes interfaces with } \\
\text { Private Contractor for } \\
\text { administrative requirements } \\
\text { for permitting and } \\
\text { compliance. }\end{array}$ \\
\hline
\end{tabular}

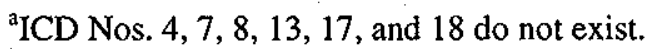

bIs the document to be maintained current per HNF-1900, Tank Waste Remediation System Configuration Management Plan (Vann et al. 1998)?

DOE $=$ U.S. Department of Energy.
ICD $=$ interface control document.
ORP $=$ Office of River Protection.
RPP $=$ River Protection Project.
TRU $=$ transuranic.




\subsection{INPUT INTERFACE CONTROL DOCUMENTS}

The following subsections describe two ICDs that define inputs to the Private Contractor of LAW and HLW from the Waste Feed Delivery System.

\subsubsection{Low-Activity Waste Feed (ICD 19)}

The delivery of LAW feed by the ORP/RPP team is an important function of the Waste Feed Delivery System managed under the RPP (see Section 3.0 of this document).

Responsibilities of the ORP/RPP team include selecting the waste envelopes and waste quantities consistent with the privatization contract and providing tank waste feed composition before transfer to the BNFL facilities.

\subsubsection{High-Level Waste Feed (ICD 20)}

The delivery of pretreated HLW feed as defined in the privatization contract also is an important function of the Waste Feed Delivery System. Responsibilities of the ORP/RPP team include transferring the HLW feed consistent with the specifications.

\subsection{SUPPORTING SYSTEM INTERFACE CONTROL DOCUMENTS}

The following subsections describe the nine privatization ICDs that define supporting systems and infrastructure support to the Private Contractor.

\subsubsection{Raw Water (ICD 01)}

The 200 East Area raw water system, managed by DYN (see Section 8.0 of this document), provides untreated Columbia River (raw) water for process use and fire suppression for 200 East Area facilities.

\subsubsection{Potable Water (ICD 02)}

The 200 East Area sanitary water system, managed by DYN (see Section 8.0 of this document), provides potable water for worker use.

\subsubsection{Land for Siting (ICD 09)}

Appropriate land required for Private Contractor waste treatment services is provided in the southeastern portion of the 200 East Area. Land for facility siting is provided to the Private Contractor under a no-cost lease that authorizes BNFL to use the property for construction, operation, and deactivation. Baseline site and environmental conditions are established by an independent third party. 


\subsubsection{Electricity (ICD 11)}

The RPP contractor and the Private Contractor consume electricity. On the Hanford Site, DYN is responsible for providing and maintaining this utility during construction and operation (see Section 8.0 of this document). BNFL specifies their peak and steady-state power demands.

\subsubsection{Roads and Rails (ICD 12)}

The primary roads and government rail system provide access to and from the 200 East Area as well as to the rest of the Hanford Site. No direct rail link is provided to the Private Contractor sites. Hanford Site roads and the rail system are maintained by DYN (see Section 8.0 of this document). The DOE/PHMC team responsibilities related to roads and rails include providing road access between the Private Contractor's site boundary and existing Hanford Site roads, and maintaining existing roads and rail system spurs in the vicinity of the BNFL facilities.

\subsubsection{Air Emissions (ICD 22)}

Air emissions from the BNFL facilities are regulated by the U.S. Environmental Protection Agency; the Washington State Department of Health, through requirements in the DOE-managed Hanford Site Air Operating Permit (to be issued); and applicable regulations. The ORP/RPP team responsibilities include revising and concurring with notices of construction, seeking modifications to the air operating permit, allocating emissions to BNFL, and using the existing monitoring network to collect required air samples.

\subsubsection{Waste Treatability Samples (ICD 23)}

BNFL conducts waste treatability studies during Privatization Phase 1B to develop information in support of treatment facility design, safety basis, and permitting. Addition samples are expected to be needed in Phase 2. The ORP/RPP team supplies the required samples and accepts the treated residues back for disposition.

\subsubsection{Emergency Response (ICD 25)}

This interface covers organization, authorities, and responsibilities for response to and mitigation of emergency events involving BNFL facilities and the Hanford Site. The DOE/PHMC team maintains and implements the emergency response plan and procedures to incorporate BNFL notification.

\subsubsection{Permits}

The ORP/RPP team is responsible for reviewing and commenting on treatment facility permit application(s), providing Hanford Site information for use in permit applications and modifications, and requesting modifications of Hanford Site permits, as appropriate, to incorporate BNFL activities. 


\subsection{OUTPUT INTERFACE CONTROL DOCUMENTS}

The following subsections describe seven "output" interfaces (i.e., those that involve delivery or return of products and by-products by the Private Contractor).

\subsubsection{Radioactive Solid Wastes (ICD 03)}

Radioactive solid wastes are managed and disposed of by facilities in the 200 West Area of the Hanford Site by WMH (see Section 7.0 of this document). Low-level, low-level mixed, TRU, and TRU-mixed solid wastes may be generated by the Private Contractor. These wastes are transferred to WMH for management and disposal.. The RPP contractor also generates radioactive solid waste that is managed and disposed of by WMH.

\subsubsection{Nonradioactive, Nondangerous Liquid Effluent (ICD 05)}

Nonradioactive, nondangerous liquid effluents generated by the Private Contractor and the PHMC team may be discharged directly to the 200 East Area TEDF, which is managed by WMH (see Section 7.0 of this document). Both the RPP contractor and the Private Contractor are expected to generate nonradioactive, nondangerous liquid effluents. The ORP/RPP team responsibilities related to nonradioactive, nondangerous liquid effluents include accepting liquid effluents per the ICD-established volumes and flow rates and providing and maintaining a transfer pipeline from the Private Contractor's site to the 200 East Area TEDF.

\subsubsection{Radioactive, Dangerous Liquid Effluents (ICD 06)}

Dilute radioactive and/or dangerous liquid effluents may be generated by the RPP contractor and/or the Private Contractor. These wastes require treatment to meet acceptance criteria for discharge to the LERF and/or to the ETF for subsequent treatment by WMH (see Section 7.0 of this document). The ORP/RPP team responsibilities related to radioactive, dangerous liquid effluents include accepting effluents per the ICD-established volumes and flow rates, providing and maintaining a RCRA-compliant transfer pipeline between the Private Contractor's site boundaries and the ETF/LERF, and disposing of secondary solid waste resulting from water treatment at the ETF/LERF.

\subsubsection{Deactivated Facility and Site (ICD 10)}

Facilities that have been deactivated are transferred to the ORP/RPP team for surveillance and maintenance, decontamination and decommissioning, and final closure. Typical facilities to be deactivated include the land; Private Contractor improvements to the land, government-furnished property and equipment; transfer pipelines and diversion boxes; nuclear processing facilities; and support buildings. The ORP/RPP team authorizes facility deactivation to be performed by the Private Contractor. 


\subsubsection{Immobilized High-Level Waste (ICD 14)}

The IHLW is processed by BNFL and sealed in canisters suitable for interim storage and future emplacement in a geologic repository. The RPP manages the program that provides the IHLW storage facility (See Section 6.0 of this document). The ORP/RPP team responsibilities related to IHLW include providing clean, approved shipping containers and picking up and accepting loaded shipping containers from the Private Contractor facility.

\subsubsection{Immobilized Low-Activity Waste (ICD 15)}

The ILAW product suitable for disposal on the Hanford Site is generated by the Private Contractor and further managed by the PHMC team. The RPP manages the program to provide ILAW disposal facilities (see Section 6.0 of this document). The ORP/RPP team responsibilities related to ILAW include providing clean, approved shipping containers and picking up and accepting the ILAW product.

\subsubsection{Entrained Solids (ICD 16)}

The entrained solids contained in the LAW feed separated from tank waste by the Private Contractor are transferred to the RPP if the treatment facilities are unable to treat them in a costeffective manner. 
HNF-1901 Rev 1

This page intentionally left blank. 


\subsection{PRODUCT STORAGE AND DISPOSAL}

The Immobilized Waste Storage and Disposal Program is responsible for ensuring that the products from Private Contractor facilities are received, transported, stored, and disposed of properly. The products that are transferred back for management by the RPP contractor include the following:

- The ILAW, which is disposed of at the Hanford Site in below-grade vaults

- The IHLW, which is stored at the Hanford Site and then shipped off Site for disposal

- Entrained solids, ${ }^{90} \mathrm{Sr}$, TRU elements, ${ }^{137} \mathrm{Cs}$, and ${ }^{99} \mathrm{Tc}$, which are stored at the Hanford Site pending future decision making about final disposition (e.g., recovery, use, immobilization).

Primary source documents regarding the scope and basis for product storage and disposal include Approval of Critical Decisions for Phase 1 Immobilized High-Level and Low-Activity Waste Interim Storage and Tank Farm Restoration and Safe Operations Projects (Projects W-464, W-465, and W-314) (Alm 1996); HNF-1517, River Protection Project Immobilized Low-Activity Waste Disposal Plan (Burbank 1999); and HNF-1751, River Protection Project Immobilized High-Level Waste Storage Plan (Calmus 1999b). This section briefly summarizes the scope of the Immobilized Waste Storage and Disposal Program and identifies technical baseline documents that support related startup and continued operations throughout the TWR\&D mission. This section does not address secondary wastes from the Private Contractor (see Section 7.0 of this document). Table 6 lists the technical baseline documents identified to date for the Immobilized Waste Storage and Disposal Program, along with summaries of the source information for each listed document. A brief summary of each listed document and other pertinent information is contained in Appendix E.

\subsection{PRIMARY WASTE AND PRODUCT DEFINITIONS}

Tank waste definition is addressed in Section 3.1 of this document. The best-basis inventory (Kupfer et al. 1999) is the most current summary of tank waste composition. Up to now, there has been no basis for defining the products from the Private Contractor. This definition is being completed in accordance with the privatization ICDs established between the RPP team and the Private Contractor (see Section 5.0 of this document) and in accordance with the characterization requirements of Standard 3 (Products and Secondary Wastes Plan) and Specifications 1, 2, 3, 4, 5 , and 6 of the privatization contract (RL 1998). 
Table 6. Summary of Source Product Storage and Disposal Documents. (4 Sheets)

\begin{tabular}{|c|c|c|c|}
\hline Document & $\begin{array}{l}\text { Maintained } \\
\text { current?* }\end{array}$ & $\begin{array}{l}\text { Appendix } \\
\text { number }\end{array}$ & Source information \\
\hline $\begin{array}{l}\text { Approval of Critical Decisions for } \\
\text { Phase } 1 \text { Immobilized High-Level } \\
\text { and Low-Activity Waste Interim } \\
\text { Storage and Tank Farm } \\
\text { Restoration and Safe Operations } \\
\text { Projects (Projects W-464, W-465, } \\
\text { and W-314) (Alm 1996) }\end{array}$ & No & E.1 & $\begin{array}{l}\text { Identifies immobilized } \\
\text { wastes to be stored. }\end{array}$ \\
\hline $\begin{array}{l}\text { HNF-1517, River Protection } \\
\text { Project Immobilized Low-Activity } \\
\text { Waste Disposal Plan } \\
\text { (Burbank 1999) }\end{array}$ & Yes & E. 2 & $\begin{array}{l}\text { Defines baseline program- } \\
\text { planning elements for } \\
\text { ILAW design, construction, } \\
\text { and operation. }\end{array}$ \\
\hline $\begin{array}{l}\text { HNF-1715, River Protection } \\
\text { Project Immobilized High-Level } \\
\text { Waste Interim Storage Plan } \\
\text { (Calmus 1999b) }\end{array}$ & Yes & E. 3 & $\begin{array}{l}\text { Defines baseline program- } \\
\text { planning elements for } \\
\text { IHLW design, construction, } \\
\text { and operation. }\end{array}$ \\
\hline $\begin{array}{l}\text { Revised Interim Policy on } \\
\text { Regulatory Structure for Low- } \\
\text { Level Radioactive Waste } \\
\text { Management and Disposal } \\
\text { (Guimond and O'Toole 1996) }\end{array}$ & No & E. 4 & $\begin{array}{l}\text { Establishes request for U.S. } \\
\text { Nuclear Regulatory } \\
\text { Commission concurrence } \\
\text { that ILAW can be disposed } \\
\text { of as "incidental waste". }\end{array}$ \\
\hline $\begin{array}{l}\text { WHC-SD-W465-AGA-001, } \\
\text { Alternatives Generation and } \\
\text { Analysis Report for Immobilized } \\
\text { Low-Level Waste Interim Storage } \\
\text { Architecture (Burbank 1996) }\end{array}$ & No & E.5 & $\begin{array}{l}\text { Establishes disposal options } \\
\text { and facilities for ILAW. }\end{array}$ \\
\hline $\begin{array}{l}\text { HNF-SD-TWR-AGA-004, } \\
\text { Analysis of Alternatives for } \\
\text { Immobilized Low-Activity Waste } \\
\text { Disposal (Burbank and } \\
\text { Klem 1997) }\end{array}$ & No & E.6 & $\begin{array}{l}\text { Establishes disposal options } \\
\text { and facilities for ILAW. }\end{array}$ \\
\hline $\begin{array}{l}\text { WHC-SD-WM-TA-183, } \\
\text { High-Level Waste Interim Storage } \\
\text { Architecture Selection - Decision } \\
\text { Report (Calmus 1996b) }\end{array}$ & No & E.7 & $\begin{array}{l}\text { Establishes storage options } \\
\text { and facilities for IHLW. }\end{array}$ \\
\hline
\end{tabular}


HNF-1901 Rev 1

Table 6. Summary of Source Product Storage and Disposal Documents. (4 Sheets)

\begin{tabular}{|c|c|c|c|}
\hline Document & $\begin{array}{l}\text { Maintained } \\
\text { current?* }\end{array}$ & $\begin{array}{l}\text { Appendix } \\
\text { number }\end{array}$ & Source information \\
\hline $\begin{array}{l}\text { HNF-3899, Immobilized High- } \\
\text { Level Waste Interim Storage } \\
\text { Alternative Generation and } \\
\text { Analysis Decision Report) } \\
\text { (Calmus 1999a) }\end{array}$ & . & & $\begin{array}{l}\text { Revisits storage options and } \\
\text { facilities for IHLW, } \\
\text { including program } \\
\text { developments since } \\
\text { previous alternative } \\
\text { selection was performed. }\end{array}$ \\
\hline $\begin{array}{l}\text { HNF-4003, Reanalysis of } \\
\text { Alternatives for Immobilized Low- } \\
\text { Activity Waste Disposal } \\
\text { (Burbank and Hohl 1999) }\end{array}$ & & & $\begin{array}{l}\text { Revisits disposal options } \\
\text { and facilities for ILAW, } \\
\text { including program } \\
\text { developments since } \\
\text { previous alternative } \\
\text { selection was performed. }\end{array}$ \\
\hline $\begin{array}{l}\text { HNF-SD-WM-RPT-294, Decision } \\
\text { Document for the Final } \\
\text { Disposition of Cesium and } \\
\text { Strontium Capsules } \\
\text { (Claghorn 1997) }\end{array}$ & ... No & F 8 & $\begin{array}{l}\text { Discusses how and when } \\
\text { the Hanford Site prepares } \\
{ }^{137} \mathrm{Cs} /{ }^{90} \mathrm{Sr} \text { capsules for } \\
\text { disposal. }\end{array}$ \\
\hline $\begin{array}{l}\text { HNF-2298, Conceptual Design } \\
\text { Report for Immobilized High-Level } \\
\text { Waste Interim Storage Facility } \\
\text { Project (Burgard 1998) }\end{array}$ & & & $\begin{array}{l}\text { Provides conceptual design, } \\
\text { cost estimate, and schedule } \\
\text { to retrofit the Hanford Site } \\
\text { Canister Storage Building to } \\
\text { interim store Privatization } \\
\text { Phase } 1 \text { IHLW. }\end{array}$ \\
\hline $\begin{array}{l}\text { HNF-1975, Conceptual Design } \\
\text { Report Immobilized Low-Activity } \\
\text { Waste Interim Storage Facility } \\
\text { (Phase 1) Project W-465 } \\
\text { Conceptual Design Report } \\
\text { (Pickett 1998) }\end{array}$ & & & $\begin{array}{l}\text { Provides conceptual design, } \\
\text { cost estimate, and schedule } \\
\text { to retrofit the Hanford Site } \\
\text { grout vaults to } \\
\text { accommodate Privatization } \\
\text { Phase } 1 \text { ILAW. }\end{array}$ \\
\hline $\begin{array}{l}\text { FDH-9858052, Conceptual Design } \\
\text { Report, Immobilized Low-Activity } \\
\text { Waste Disposal Facility, Project } \\
\text { W-520, transmitted to DOE on } \\
\text { 09/29/98 via letter FDH-9858052 } \\
\text { (FDH 1998) }\end{array}$ & & & $\begin{array}{l}\text { Provides conceptual design, } \\
\text { cost estimate, and schedule } \\
\text { to design/construct a new } \\
\text { ILAW storage facility to } \\
\text { accommodate Privatization } \\
\text { Phase } 1 \text { ILAW. }\end{array}$ \\
\hline
\end{tabular}


HNF-1901 Rev 1

Table 6. Summary of Source Product Storage and Disposal Documents. (4 Sheets)

\begin{tabular}{|c|c|c|c|}
\hline Document & $\begin{array}{l}\text { Maintained } \\
\text { current?* }\end{array}$ & $\begin{array}{l}\text { Appendix } \\
\text { number }\end{array}$ & Source information \\
\hline $\begin{array}{l}\text { Contract Number } \\
\text { DE-AC06-96-RL13200-Decision } \\
\text { Document for the Final } \\
\text { Disposition of Cesium and } \\
\text { Strontium Capsules, HNF-SD- } \\
\text { WM-294, (Taylor 1997) }\end{array}$ & No & E.9 & $\begin{array}{l}\text { Establishes disposition basis } \\
\text { for }{ }^{137} \mathrm{Cs} /{ }^{90} \mathrm{Sr} \text { capsules. }\end{array}$ \\
\hline $\begin{array}{l}\text { Project W-464 technical baseline } \\
\text { documents (See listing of technical } \\
\text { baseline documents in } \\
\text { Appendix G.) }\end{array}$ & Yes & E. 10 & $\begin{array}{l}\text { Technical baseline } \\
\text { documents related to the } \\
\text { W-464 Project, } \\
\text { Immobilized Low-Activity } \\
\text { Waste Interim Storage. }\end{array}$ \\
\hline $\begin{array}{l}\text { Project W- } 465 \text { technical baseline } \\
\text { documents (See listing of technical } \\
\text { baseline documents in } \\
\text { Appendix G.) }\end{array}$ & Yes & E.11 & $\begin{array}{l}\text { Technical baseline } \\
\text { documents related to the } \\
\text { W-465 Project, } \\
\text { Immobilized Low-Activity } \\
\text { Waste Interim Storage. }\end{array}$ \\
\hline $\begin{array}{l}\text { WHC-SD-WM-EE-004, } \\
\text { Performance Assessment of } \\
\text { Grouted Double-Shell Tank Waste } \\
\text { Disposal at Hanford } \\
\text { (Shade et al. 1994) }\end{array}$ & No & E.12 & $\begin{array}{l}\text { Discusses relationship of } \\
\text { ILAW to ongoing } \\
\text { performance assessments } \\
\text { and that existing grout } \\
\text { vaults are sufficient for first } \\
\text { four years of Privatization } \\
\text { Phase } 1 \text { operation. }\end{array}$ \\
\hline $\begin{array}{l}\text { HNF-EP-0 } 884, \text { Hanford Low- } \\
\text { Level Tank Waste Interim } \\
\text { Performance Assessment (Mann } \\
\text { et al. 1997) }\end{array}$ & No & E.13 & $\begin{array}{l}\text { Examines long-term health } \\
\text { and environmental effects } \\
\text { associated with disposal in } \\
\text { the Hanford Site } 200 \text { East } \\
\text { Area of LAW from single- } \\
\text { shell and double-shell tanks. }\end{array}$ \\
\hline $\begin{array}{l}\text { HNF-SD-ENV-EE-003, Permitting } \\
\text { Plan for the Immobilized Low- } \\
\text { Activity Waste Project } \\
\text { (Deffenbaugh et al. 1997) }\end{array}$ & No & E.14 & $\begin{array}{l}\text { Establishes requirements, } \\
\text { alternatives, implementation } \\
\text { strategy, and estimated costs } \\
\text { for environmental permits } \\
\text { and compliance. }\end{array}$ \\
\hline $\begin{array}{l}\text { Environmental Requirements } \\
\text { Checklist for the High-Level Waste } \\
\text { Storage Project Canister Storage } \\
\text { Building (Deffenbaugh 1996) }\end{array}$ & No & E.15 & $\begin{array}{l}\text { Establishes requirements, } \\
\text { alternatives, implementation } \\
\text { strategy, and estimated costs } \\
\text { for environmental permits } \\
\text { and compliance. }\end{array}$ \\
\hline
\end{tabular}


HNF-1901 Rev 1

Table 6. Summary of Source Product Storage and Disposal Documents. (4 Sheets)

\begin{tabular}{|l|c|c|l|}
\hline \multicolumn{1}{|c|}{ Document } & Maintained & Appendix & \multicolumn{1}{|c|}{ Source information } \\
\hline $\begin{array}{l}\text { Humb-SD-ENV-EE-002, Permitting } \\
\text { Plan for the High-Level Waste } \\
\text { Interim Storage Project W-464 } \\
\text { (Deffenbaugh 1997) }\end{array}$ & No & E.16 & $\begin{array}{l}\text { Establishes requirements, } \\
\text { alternatives, implementation } \\
\text { strategy, and estimated costs } \\
\text { for environmental permits } \\
\text { and compliance. }\end{array}$ \\
\hline $\begin{array}{l}\text { Memorandum of Agreement } \\
\text { (MOA) - Utilization of Canister } \\
\text { Storage Building (CSB) Vaults } 2 \\
\text { and 3 for Immobilized High-Level } \\
\text { Tank Waste (Hansen 1996) }\end{array}$ & No & E.17 & $\begin{array}{l}\text { Describes the attributes of } \\
\text { Vaults 2 and 3 of the } \\
\text { Canister Storage Building } \\
\text { and discusses features to } \\
\text { facilitate addition of more } \\
\text { vaults later. }\end{array}$ \\
\hline
\end{tabular}

\footnotetext{
Configuration Management Plan (Vann et al. 1998)?

IHLW $=$ immobilized high-level waste.

ILAW $=$ immobilized low-activity waste.

NRC $=$ U.S. Nuclear Regulatory Commission.
}

*Is the document to be maintained current per HNF-1900, Tank Waste Remediation System

\subsection{PROCESS DEFINITION}

During Privatization Phase $1, \mathrm{LAW}$ from the equivalent of approximately 12 DSTs is treated by the Private Contractor, and the resultant ILAW is disposed of on Site in below-grade vaults. This disposal option is predicated on assumed concurrence from the U.S. Nuclear Regulatory Commission that the ILAW can be disposed of as "incidental waste" (Revised Interim Policy on Regulatory Structure for Low-Level Radioactive Waste Management and Disposal [Guimond and O'Toole 1996]).

The Private Contractor may be selected to treat the HLW, and the resultant IHLW is stored on Site, in the Hanford Site Canister Storage Building (CSB) and eventually shipped off Site for disposal. The CSB accommodates interim storage of the majority of the Privatization Phase 1 IHLW canisters; however, another facility needs to be brought on-line to accommodate a Phase 1 canister count greater than the CSB capacity ( 880 canisters). A recommended facility to accommodate the expanded Phase 1 capacity is the retrofit of the Hanford Site Fuels and Materials Examination Facility. At this time, the expected disposal facility for the IHLW is the geologic repository being developed by the Office of Civilian Radioactive Waste Management near Las Vegas, Nevada.

Product streams containing entrained solids, TRU elements, ${ }^{90} \mathrm{Sr}$, and ${ }^{99} \mathrm{Tc}$ are returned from the Private Contractor to the PHMC team. Negotiations between DOE and the Private Contractor define the return conditions for these product streams. Cesium-137 and ${ }^{90} \mathrm{Sr}$ capsules from previous Hanford Site operations currently are stored in the Waste Encapsulation and Storage 
Facility. The DOE may decide to open the capsules and immobilize the high-heat-generating

${ }^{137} \mathrm{Cs}$ and ${ }^{90} \mathrm{Sr}$ salts in the Private Contractor immobilization system. The current baseline plan is that the Private Contractor with the HLW option incorporates ${ }^{137} \mathrm{Cs},{ }^{99} \mathrm{Tc}$, and ${ }^{90} \mathrm{Sr} / \mathrm{TRU}$ into the IHLW product in Privatization Phase 2. Technical baseline information for these product streams cannot be further defined until the final Phase 1B Privatization Contractor's process design is finalized.

\subsubsection{Immobilized Low-Activity Waste}

The Immobilized Waste Storage and Disposal Program's mission includes receiving ILAW packages produced by the Private Contractor, transporting the packages to a disposal site within the Hanford Site 200 Areas, and disposing of the packages in a manner that does not preclude retrieval. The selected facility for the initial (Privatization Phase 1) ILAW is the former unfilled grout vaults facility located in the 200 East Area with subsequent ILAW disposal to occur in a new facility. The initial alternatives and recommendations for the facility options are analyzed in

WHC-SD-W465-AGA-001, Alternatives Generation and Analysis Report for Immobilized LowLevel Waste Interim Storage Architecture (Burbank 1996), and HNF-SD-TWR-AGA-004, Analysis of Alternatives for Immobilized Low-Activity Waste Disposal (Burbank and Klem 1997). A reanalysis of the alternatives was conducted in HNF-4003, Reanalysis of Alternatives for Immobilized Low-Activity Waste Disposal (Burbank and Hohl 1999).

Packages of ILAW are supplied by the Private Contractor to the ORP/RPP team in accordance with contract specifications described in the privatization contract. The ILAW disposal project includes activities and functions to provide and operate product transportation and disposal facilities for ILAW packages and provide permanent disposal on the Hanford Site. Initial production (Privatization Phase 1) is managed in the existing four grout vaults as part of Project W-465. Later production (Phase 2) is disposed of in additional facilities in the 200 East Area in a separate LAW disposal complex under Project W-520. These permanent disposal systems are being designed to accommodate the complete inventory of ILAW packages produced during the treatment of Hanford Site tank waste, including Phase 2 packages.

\subsubsection{Immobilized High-Level Waste}

The Immobilized Waste Storage and Disposal Program's mission includes receiving IHLW produced by the Private Contractor, transporting the products to an acceptable Hanford Site interim storage facility, and storing the products safely and economically until they can be shipped to a permanent facility or returned to a Private Contractor for further processing. The primary objective is to provide onsite transportation systems and interim storage facilities for Privatization Phase 1 and 2 HLW products, which involves two primary projects. One project provides an onsite HLW product transportation system and retrofit of the Hanford Site CSB to accommodate Phase $1 \mathrm{HLW}$ products. The other project designs and constructs new facilities to accommodate Phase 2 HLW products. The selection bases for these projects initially were discussed in WHC-SD-WM-TA-183, High-Level Waste Interim Storage Architecture Selection Decision Report (Calmus 1996b). A subsequent basis was developed to account for changes in 
the contract between the Private Contractor and DOE in HNF-3899, Immobilized High-Level Waste Interim Storage Alternatives Generation and Analysis Decision Report (Calmus 1999a).

Retrofit of the CSB (Project W-464, HLW Interim Storage Project) provides the capability to interim store IHLW canisters in CSB Vaults 2 and 3. The IHLW canisters are interim stored in the CSB (under Hanford Site Project W-464) until the HLW can be transferred off Site to a final Office of Civilian Radioactive Waste Management disposal facility. Project W-464 scope includes a transportation system for the shipment of IHLW from the Private Contractor to the CSB and staging of the IHLW canisters for offsite shipment.

\subsubsection{Cesium/Strontium Capsules}

A primary objective of the Immobilized Waste Storage and Disposal Program is to evaluate and select the path forward for disposal of the ${ }^{137} \mathrm{Cs} /{ }^{90} \mathrm{Sr}$ capsules located at the Hanford Site by the end of fiscal year 1997 and, if appropriate, implement the selected option. A recommended approach has been submitted to DOE in HNF-SD-WM-RPT-294, Decision Document for the Final Disposition of Cesium and Strontium Capsules (Claghorn 1997). DOE subsequently concurred with the recommendation in a letter to FDH, 97-WDD-058A, Contract Number DE-AC06-96-RL13200 - Decision Document for the Final Disposition of Cesium and Strontium Capsules (Taylor 1997), to blend the ${ }^{137} \mathrm{Cs} /{ }^{90} \mathrm{Sr}$ capsules into the Privatization Phase $2 \mathrm{HLW}$ immobilization plant feed. Therefore, ${ }^{137} \mathrm{Cs} /{ }^{90} \mathrm{Sr}$ capsules are not included in the Phase 1 Immobilized Waste Storage and Disposal Program.

\subsection{MISSION PLANNING}

Activities required to achieve the objectives of the product storage and disposal mission are described in the RPP level 0 logic and in HNF-SP-1230 (Lenseigne 1998). The level 0 logic depicts approximately 100 sequentially linked, broadly scoped activities that, when completed, satisfy the RPP mission objectives. More detailed activities for Projects W-464 (CSB retrofitIHLW, Privatization Phase 1), W-465 (Grout Vault retrofit-ILAW, Phase 1), and W-520 (new facility construction - ILAW, Phase 2) and for other program tasks are developed and updated at the work breakdown structure 1.1.3.4 level in the RPP multiyear work plan. Guidance for developing the multiyear work plans includes specification of which technical baseline documents to produce, use, revise, and delete.

\subsection{STRUCTURES, SYSTEMS, AND COMPONENTS}

The SSCs for product storage and disposal are defined to include the equipment and other systems required to transport, receive, store, and disposition products and wastes from the Private Contractor. Transportation systems and retrofitted/designed Privatization Phase 1 and 2 storage and disposal facilities are in accordance with established ILAW design requirements found in HNF-SD-W465-DRD-001, Design Requirements Document for Project W-465, Immobilized Low-Activity Waste Interim Storage (Burbank 1997) and IHLW design requirements found in WHC-SD-WM-DRD-012, Design Requirements Document for Interim Storage Phase 1 Solidification of High-Level Waste (Calmus 1996a). These and other design- 
basis documents identify specific facility components, instrumentation, control systems, and ancillary equipment required to receive and manage the Private Contractor products. The SSCs are further developed in the respective project-detailed design activities.

\subsubsection{System and Project Definition}

6.4.1.1 Immobilized Low-Activity Waste. Four existing, empty, subsurface vaults in the 200 East Area, formerly planned to hold slurry wastes mixed with cement-based products, initially are being used as interim ILAW disposal facilities. These vaults are being modified to receive and dispose of approximately 7,000 packages $\left(1.4 \mathrm{~m}^{3}\right.$ stainless steel boxes $)$ of ILAW determined to be "incidental wastes" by the U.S. Nuclear Regulatory Commission (thereby excluding them from U.S. Nuclear Regulatory Commission licensing requirements). The ability of the existing vaults to perform adequately for disposal has been previously assessed in WHC-SD-WM-EE-004, Performance Assessment of Grouted Double-Shell Tank Waste Disposal at Hanford (Shade et al. 1994) and more recently in HNF-4003 (Burbank and Hohl 1999). Disposal of LAW in the Hanford Site 200 East Area has been assessed in HNF-EP-0884, Hanford Low-Level Tank Waste Interim Performance Assessment (Mann et al. 1997). Additional disposal facilities are being constructed as necessary to accommodate the remainder of Privatization Phase 1 (>7,000 packages) and completion of Phase 2 wastes. The planned ILAW activities are outlined in HNF-1517 (Burbank 1999) and covered in other planning documents under Project W-465: The ILAW activities continue to be updated to reflect changes in planning guidance and development of the privatization contract phases.

Up to 7,900 packages may be produced during the Phase 1 privatization contract; therefore, additional disposal space is required beyond the Project W-465 grout vaults. Additional facilities, designated as the LAW Disposal Complex, are planned for the south-central portion of the 200 East Area for Privatization Phase 1 production that exceeds the grout vault capacity and the ILAW production expected during Phase 2 . Depending on the level of package radioactivity, some ILAW packages may require remote handling (but can be disposed of commonly with contact-handled packages). The package activity level, combined with the package hazardous waste classification, is expected to allow both trench and vault disposal concepts to be used.

6.4.1.2 Immobilized High-Level Waste. The CSB is located in the Hanford Site 200 East Area (Building 212-H) and currently is being constructed as part of the Spent Nuclear Fuel (SNF) Project (Project W-379). After the SNF CSB construction is finished, the IHLW Storage Project (Project W-464) intends to outfit the CSB by installing new features to enable receipt and storage of Privatization Phase 1 IHLW. The SNF Project is using Vault 1 for interim storage of SNF; Project W-464 is retrofitting Vaults 2 and 3 for interim storage of IHLW. Project W-464 also includes a system for transporting IHLW canisters from the Private Contractor facilities to the CSB.

Using the CSB for interim storage of Privatization Phase 1 IHLW requires installation of equipment and subsystems independent of the SNF CSB design. The existing CSB facility also may need to be modified. The extent of CSB modifications is being determined in the conceptual and detailed design phases. Potential needs such as modifying the inlet plenum to 
allow louver installation, construction of a new receipt/transfer annex, and procurement of a rubber-tired shielded canister transport system similar to that currently being used at the Savannah River Site's Defense Waste Processing Facility, may be identified during conceptual design. In addition to the required CSB equipment, a new: onsite transporter system, including a tractor/trailer and onsite shielded transport cask, may need to be specified and procured.

\subsubsection{Project Records}

Project files are developed and maintained in accordance with project configuration management plans. Documents associated with projects (e.g., drawings, calculations, correspondence, test, vendor information) are maintained as records and processed through the DIMCs. The project files are complete, accurate, and made available to support projects for the Privatization Phase 1 and 2 ILAW and IHLW product handling. Information resources are managed throughout the information life-cycle, including information creation, collection, processing, distribution, management, and disposition or retirement. Life-cycle activities are managed toward making information useful, available, and effective in accomplishing project objectives.

The selection of controlled documents and information is in accordance with HNF-1900 (Vann et al. 1998) and implementing procedures.

\subsubsection{Reliability, Availability, and Maintainability Risk Evaluation}

Risk planning, assessment, analysis, and management is used throughout the product storage and disposal activities to identify significant risk factors and formulate mitigation plans. Risk management is conducted in accordance with RPP risk management programs (e.g., HNF-SD-WM-PMP-018, Tank Waste Remediation System Risk Management Plan [Zimmerman 1998]). In addition, RAM risk evaluations are generated as major project phases are developed. Risk assessment is an ongoing, iterative, integrated process providing information needed to manage technical, environmental, safety, and health risks. The RAM risk analyses also provides the basis for revising design requirements; anticipating spare equipment, training, and other project needs; and identifying potential programmatic impacts (e.g., scope, cost, schedule).

\subsubsection{Spare Equipment List}

With the exception of several line-item projects, SSCs are in place. However, designs and engineering plans for storage/disposal projects are insufficiently complete at this time to prepare lists of project critical spare parts and equipment. The RAM evaluation, vendor recommendations, reviews of historical performance, and other assessments of the ILAW and IHLW management projects provide the basis for the spare equipment list. 
HNF-1901 Rev 1

\subsection{OPERATIONS, MAINTENANCE, AND SUPPORTING DOCUMENTS}

Operations, maintenance, and supporting documents are those that are used to enable and control field activities. The Immobilized Waste Storage and Disposal Program has recently initiated designs and engineering plans for the expected product storage and disposal activities. Thus, many of the following sections are only conceptual at this time or are intended to act as placeholders for future discussion and amendment of this document.

\subsubsection{Operations and Maintenance Concept}

Operations and maintenance concepts for product storage and disposal are being developed from a combination of sources including derivation from existing practices or previous concepts (e.g., operating procedures for the grout vaults); adaptation of new procedures (e.g., modification of CSB maintenance procedures developed under Project W-379); and independent development of new practices (e.g., for the new ILAW disposal facility). Documents specific to operations and maintenance for product storage and disposal systems are added to and controlled under the technical baseline as they are completed.

\subsubsection{Permits and Safety Authorizations}

Environmental permit planning documents have been prepared for the product storage and disposal activities including HNF-SD-ENV-EE-003, Permitting Plan for the Immobilized Low-Activity Waste Project (Deffenbaugh et al. 1997); 70100-96-004, Environmental Requirements Checklist for the High-Level Waste Storage Project Canister Storage Building (Deffenbaugh 1996); and HNF-SD-ENV-EE-002, Permitting Plan for the High-Level Waste Interim Storage Project (Deffenbaugh 1998). For each applicable regulation, the permitting plans provide a summary of data requirements, a discussion of alternatives, a recommended implementation strategy, and an estimated cost of implementing the recommended alternative.

A comprehensive, graded approach to safety is being developed for the Immobilized Waste Storage and Disposal Program projects to integrate the appropriate safety inputs and requirements into the program's technical, cost, and schedule baselines. At this time, the RPP Authorization Basis for the Hanford Site does not include Projects W-464 or W-465, nor does it include future Privatization Phase 2 ILAW or IHLW storage and disposal facilities. The Authorization Basis is amended or another Authorization Basis is developed to address these projects and interfaces with other Hanford Site projects and with the Private Contractor.

For ILAW, the general approach is to develop a new set of safety requirements based on preliminary safety evaluation studies performed during the conceptual design stage; detailed safety analysis to establish the basis of a preliminary safety analysis report and a final safety analysis report; and TSRs to be addressed in the Project W-465 design package using the safety equipment list, specific procurement requirements, and specific testing during startup. A preliminary safety evaluation for Project W-465 is presented in HNF-SD-W465-PSE-001, Preliminary Safety Evaluation for Project W-465, Immobilized Low-Activity Waste Interim Storage (Mouette 1997). For IHLW, the strategy is to develop an addendum to the final safety analysis report prepared by Project W-379 (Canister Storage Building). This addendum follows 
the existing CSB final safety analysis report format and reflects only those activities specific to the IHLW storage mission. In addition, the addendum identifies interfaces with Project W-379 for design features, analysis, requirements, and controls specific to the IHLW mission. The HLW-specific TSRs and controls are managed as part of the CSB safety basis.

\subsubsection{Process Limits}

Process limits cannot be established at this time for product storage and disposal, primarily because the full characteristics, properties; and quantities of the ILAW and IHLW are not established yet. Process limits are developed after the privatization contract is finalized and more detailed designs completed.

\subsubsection{Safety Equipment List}

The safety equipment list for the RPP is identified in HNF-SD-WM-SEL-040 (Jensen 1998). The document identifies the operating and maintenance SSCs important to safety and provides the requirements to support occurrence reporting activities for RPP operations. The facility safety equipment list is augmented by the operator(s) of the ILAW and IHLW storage and disposal facilities: HNF-SD-WM-SEL-040 (Jensen 1998) is updated to cover facilities that support the transport and disposition of products delivered by the Private Contractor.

\subsubsection{Operations and Maintenance Environment, Safety, and Health and Quality Assurance Plans}

The Immobilized Waste Storage and Disposal Program establishes the ES\&H and quality assurance programs to ensure that product storage and disposal activities are carried out in compliance with Federal, state, and local regulations, laws, and standards for the protection of the environment and the safety and health of employees and the public. Activities conducted in the RPP are in accordance with HNF-1773 (Allen 1999) and RPP procedures.

\subsubsection{Operations and Maintenance Procedures}

The Immobilized Waste Storage and Disposal Program develops operations and maintenance procedures for the product storage and disposal system. Procedure development occurs after the projects have been completed and accepted by the RPP. Operations and maintenance procedures are considered technical baseline documents.

\subsubsection{Training Certifications}

Training and certification occur after the specific procedures for operation and maintenance of the product storage and disposal system are in place. Shift supervisors, operating engineers, operators, craftsmen, and technicians are trained to the procedures. Management, engineering, and other professional staff may receive specific professional training and certification as 
necessary to ensure proficiency. Training of personnel involved in ILAW and IHLW handling and disposition likely is accomplished using the existing training infrastructure. Training certifications are considered technical baseline documents. Hanford Atomic Metals Trade Council personnel are trained and certified by the RPP contractor.

\subsubsection{Operations and Maintenance Records}

Operations and maintenance records include calibration, process performance, and system surveillance documents. After the product storage and disposal system has been defined, the Immobilized Waste Storage and Disposal Program develops procedures to govern recordkeeping activities. These records are considered to be technical baseline documents and are developed, collected, and maintained consistent with the project records procedures discussed in Section 6.4 .2 of this document.

\subsection{SECONDARY WASTE DEFINITION}

The product.storage and disposal program is not generating secondary radioactive and solid wastes now or in the near future. The secondary wastes expected under this program are operational in nature and include relatively small volumes of personal protective equipment, high-efficiency particulate air filters, and other material generated as a result of routine facility operations.

\subsection{PROGRAMMATIC INTERFACES}

The Immobilized Waste Storage and Disposal Program prepares ILAW and IHLW project management plans (HNF-1517 [Burbank 199] and HNF-1751 [Calmus 1999b], respectively) that include details on program interfaces. The program management plans describe interactions among and responsibilities of the ORP/RPP team, the architect/engineer, the constructor, the Private Contractor, and permitting authorities such as Ecology.

The functional elements of the transport systems, interim storage, and final disposal facilities depend on the ILAW and IHLW products received from the Private Contractor. An interface process has been established to define responsibilities and resolve issues. This interface is conducted in accordance with privatization ICDs specific to each LAW and HLW product (see Section 5.0 of this document). The privatization ICDs are to be issued by DOE and the Private Contractor in FY 1999. The Memorandim of Agreement (MOA)-Utilization of Canister Storage Building (CSB) Vaults 2 and 3 for Immobilized High-Level Tank Waste (Hanson 1996) between the SNF Project and IHLW storage subproject has been executed to reserve CSB Vaults 2 and 3 for storing Privatization Phase 1 IHLW products. 


\section{HNF-1901 Rev 1}

The product storage and disposal system is supported by utilities and other infrastructure services provided by DYN. An agreement in principle between LMHC and DYN was executed to ensure delivery of the required services (see Section 8.0 of this document). A similar agreement between LMHC and WMH was prepared to ensure that product storage and disposal are supported with adequate facilities, operations, management, laboratory analytical services, and other required support (see Section 7.0 of this document). 
HNF-1901 Rev 1

This page intentionally left blank. 


\subsection{SECONDARY WASTE MANAGEMENT AND ANALYTICAL SUPPORT}

$\mathrm{WMH}$ is responsible for secondary waste management and analytical support. This section describes the overall scope of support provided by WMH to the TWR\&D mission and identifies technical baseline documents that apply to the scope of WMH responsibilities. Also included in this section is a brief description of the primary facilities that are involved with managing secondary waste and providing analytical support. Table 7 lists the technical baseline documents identified to date for secondary waste and analytical support, along with summaries of the source information for each listed document. A brief summary of each listed document and other pertinent information is contained in Appendix $\mathrm{F}$.

Table 7. Technical Baseline Documents for Secondary Waste and Analytical Services and Designated Source Information. (2 sheets)

\begin{tabular}{|l|c|c|c|}
\hline \multicolumn{1}{|c|}{ Document } & Maintained & Appendix & Source information \\
\hline $\begin{array}{l}\text { HNF-SD-WM-RPT-288, Waste } \\
\text { Management Project Technical } \\
\text { Baseline Description } \\
\text { (Sederburg 1997) }\end{array}$ & Yes & F.1 & $\begin{array}{l}\text { Source for information relating to } \\
\text { WMH activities, including } \\
\text { ETF/LERF, 242-A Evaporator, } \\
\text { Central Waste Complex, and } \\
\text { 222-S Laboratory. }\end{array}$ \\
\hline $\begin{array}{l}\text { HNF-EP-0918, Solid Waste } \\
\text { Integrated Forecast Technical } \\
\text { (SWIFT) Report: FY 1997 to } \\
\text { FY 2070 (Valero 1997) }\end{array}$ & Yes & F.2 & $\begin{array}{l}\text { Source for future solid-waste- } \\
\text { generation predictions. }\end{array}$ \\
\hline $\begin{array}{l}\text { BNFL-5193-ID-03, Interface } \\
\text { Control Document Between DOE } \\
\text { and BNFL Inc. for Radioactive } \\
\text { Solid Waste (BNFL 1998c) }\end{array}$ & Yes & D.3 & $\begin{array}{l}\text { Establishes interfaces with } \\
\text { Private Contractor for the } \\
\text { handling and managing of } \\
\text { radioactive solid waste. }\end{array}$ \\
\hline $\begin{array}{l}\text { BNFL-5193-ID-05, Interface } \\
\text { Control Document Between DOE } \\
\text { and BNFL Inc. for Non- } \\
\text { Radioactive, Non-Dangerous } \\
\text { Liquid Effluents (BNFL 1998d) }\end{array}$ & Yes & D.4 & $\begin{array}{l}\text { Establishes interfaces with } \\
\text { Private Contractor for the } \\
\text { handling and managing of } \\
\text { nonradioactive, nondangerous } \\
\text { liquid effluents. }\end{array}$ \\
\hline $\begin{array}{l}\text { BNFL-5193-ID-06, Interface } \\
\text { Control Document Between DOE } \\
\text { and BNFL Inc. for Radioactive, } \\
\text { Dangerous Liquid Effluents } \\
\text { (BNFL 1998e) }\end{array}$ & Yes & D.5 & $\begin{array}{l}\text { Establishes interfaces with } \\
\text { Private Contractor for the } \\
\text { handling and managing of } \\
\text { radioactive, dangerous liquid } \\
\text { effluents. }\end{array}$ \\
\hline
\end{tabular}


Table 7. Technical Baseline Documents for Secondary Waste and Analytical Services and Designated Source Information. (2 sheets)

\begin{tabular}{|l|c|c|l|}
\hline \multicolumn{1}{|c|}{ Document } & $\begin{array}{l}\text { Maintained } \\
\text { current? }\end{array}$ & $\begin{array}{c}\text { Appendix } \\
\text { number }\end{array}$ & Source information \\
\hline $\begin{array}{l}\text { BNFL-5193-ID-19, Interface } \\
\begin{array}{l}\text { Control Document Between DOE } \\
\text { and BNFL Inc. for Low-Activity } \\
\text { Waste Feed (BNFL 1998m) }\end{array}\end{array}$ & Yes & D.19 & $\begin{array}{l}\text { Establishes interfaces with } \\
\text { Private Contractor for the } \\
\text { delivery of the low-activity waste } \\
\text { feed. }\end{array}$ \\
\hline $\begin{array}{l}\text { BNFL-5193-ID-20, Interface } \\
\text { Control Document Between DOE } \\
\text { and BNFL Inc. for High-Level } \\
\text { Waste Feed (BNFL 1998n) }\end{array}$ & Yes & $\mathrm{D} .20$ & $\begin{array}{l}\text { Establishes interfaces with } \\
\text { Private Contractor for the } \\
\text { delivery of the high-level waste } \\
\text { feed. }\end{array}$ \\
\hline
\end{tabular}

${ }^{\mathrm{a}}$ Is the document to be maintained current per HNF-1900, Tank Waste Remediation System Configuration Management Plan (Vann et al. 1998)?

bAnalytical services-related interface documents have not been developed to address interfaces between private contractor and WMH.

$\mathrm{ETF}=$ Effluent Treatment Facility.

LERF $=$ Liquid Effluent Retention Facility.

WMH = Waste Management Federal Services of Hanford, Inc.

\subsection{ANALYTICAL SERVICES}

The WMH Analytical Services organization currently is responsible for analyzing and managing radioactive and nonradioactive samples of Hanford Site waste. Hanford Site facilities and activities that support this program include the 222-S Laboratory, the Waste Sampling and Characterization Facility, and special analytical support. The 222-S Laboratory provides the majority of the TWR\&D mission support and is the primary focus of this section. Highly radioactive wastes, including HLW and LAW, are analyzed in the 222-S Laboratory. Not all interfaces regarding secondary waste have been identified (i.e., requirements for the Private Contractor to use the 222-S Laboratory and the Waste Sampling and Characterization Facility laboratory services). As these interfaces are defined, agreements are developed. Analysis of réturned waste is assumed to be the responsibility of the Private Contractor (who may contract for analytical services through WMH). Important documents for laboratory analysis include HNF-SD-CP-ISB-002, 222-S Laboratory Interim Safety Basis (Weaver 1997) and DOE/RL 91-27, Dangerous Waste Part B Permit Application for the 222-S Laboratory Complex (RL 1991a). Both of these documents are required documents in WHC-SD-WM-RPT-288 (Sederburg 1997). 


\subsubsection{Facility Description}

The 222-S facility, located in the 200 West Area, is a Category 3 nonreactor nuclear facility. This facility includes the 222-S Control Laboratory and auxiliary buildings. The 222-S Control Laboratory contains the Hot Cell Facility for analyzing high-dose rate samples, a multi-curie section, and a section for analyzing general radioactive and/or toxic materials. New analytical methods and chemical standards are prepared in the 222-SA Standards/Process Development Laboratory. The 222-S facility also includes three waste management units. Recent upgrades to the waste management units and facility, including upgraded and newly installed transfer lines, ensure compliance with Title 40, Code of Federal Regulations (CFR), Part 265, "Interim Status Standards for Owners and Operators of Hazardous Waste Treatment, Storage, and Disposal Facilities," and DOE orders and provide long-term capabilities for supporting new and expanded missions (WHC-SD-W041-FDC-001, Environmental Hot Cell Expansion Project W-041 [McVey 1991]; WHC-SD-WM-ES-107, Environmental Hot Cell Expansion - Project W-041 [McVey 1992]; WHC-SD-W057-ES-001, Engineering Study 222-S High-Level Drain System Upgrade Project W-057 [LaBarge 1992]).

\subsubsection{Sample Receiving Capabilities and Limitations}

The analytical capacity of the 222-S Hot Cell Facility previously was estimated to be approximately 1,450 to 1,800 core segment samples per year (McVey 1991). The receiving capacity was limited during the estimation timeframe by the number of extrusions. Current nearterm sample projections are provided in HNF-SD-WM-TI-608, Hanford Analytical Sample Projections FY 1996 - FY 2001 (Joyce 1997). Long-term projections and requirements (e.g., protocols) are not currently available; HNF-SD-WM-RPT-288 (Sederburg 1997) identifies this as "to be determined," but capacity to support the TWR\&D mission is not expected to be of concern according to internal memorandum 65450-87-016, HWVP Analytical Hot Cells Time and Motion Study (Stroup 1987) and internal memorandum 12000-94-005, TWRS Minimum/Maximum Laboratory Capacity Strategy (Bell 1994). Analytical sample analysis needs have been decreasing, and this trend is expected to continue.

The type and magnitude of analytical support to the Private Contractor and the RPP depends on data quality objectives for tank waste and on immobilized waste analyses and further definition and revision of the ICDs described in Section 5.0 of this document. Permit impacts also are evaluated.

\subsubsection{Facility Discharges}

The 222-S Laboratory generates the following waste streams: low-level waste (LLW), mixed LLW, and hazardous waste. The primary types and sources of the LLW are routine laboratory waste, failed equipment, and lab packs. The analysis of tank farm core samples generates much of the mixed LLW. Hazardous waste also is generated in the 222-S Standards Laboratory. These waste streams are described in greater detail in WHC-SD-WM-PICD-005, Interface Control Document Between Analytical Services and Solid Waste Disposal Division (Greager 1996). Radioactive liquid waste is discharged to the DST system. Currently unused samples either are archived or are returned to the RPP. Secondary waste from sample analysis 
also currently is returned to the source owner. An agreement is being developed for the archiving or returning of samples or secondary waste from Private Contractor-related analytical support.

\subsubsection{Programmatic and Technical Interfaces}

HNF-SD-WM-RPT-288 (Sederburg 1997) contains a section devoted to interfaces. The ICD between the RPP and WMH is WHC-SD-WM-PICD-003, Interface Control Document Between the Tank Waste Remediation System and the Solid Waste Disposal Division (Duncan 1995). For the Privatization Phase 1 effort, Sederburg (1997) identifies the major interface activities "between the Private Contractor and WMH and indicates that specific ICDs are being developed. The ICDs being developed that are important to WMH are identified in Table 5 and are described in Section 5.0 of this document. An agreement in principle regarding WMH support to the TWR\&D mission has been released (LMHC 1999b). HNF-SD-SM-SD-023, Fiscal Year 1997 Memorandum of Understanding for the TWRS Characterization Project (Schreiber 1997) also serves as an interface document.

The 222-S.Laboratory; as managed through Analytical Services, also has interfaces with onsite and offsite customers and offsite laboratories. As noted in Sections 7.1 and 7.1.3, not all secondary waste interfaces have been completed. Analytical Services provides sampling, analysis, data management, and planning for other DOE sites and DOE complex-wide programs, other Federal customers including the U.S. Department of Defense, and some nongovernment entities. Offsite laboratories sometimes are used to support analysis of low-radiation-level $(<10 \mathrm{mr} / \mathrm{h}$ ) samples.: Sample analysis includes environmental monitoring, bioassay, and routine analysis of RCRA mixed waste.

\subsubsection{Additional Required and Supplemental Documentation}

HNF-SD-WM-RPT-288 (Sederburg 1997) identifies several required and supplemental documents. These documents include plant operating and maintenance procedures, essential drawings, safety equipment lists, permits, and the interim safety basis.

\subsection{2-A EVAPORATOR}

The 242-A Evaporator is operated to reduce the volume of highly radioactive waste requiring storage in the DST system. The 242-A Evaporator accepts aqueous waste from various generators on the Hanford Site through the tank-farm system and is capable of processing Private Contractor waste that meets waste acceptance criteria. Important documents for the 242-A Evaporator include DOE/RL 90-42, Hanford Facility Dangerous Waste Permit Application, 242-A Evaporator (RL 1997a) and WHC-SD-WM-SAR-023, 242-A Evaporator/Crystallizer Safety Analysis Report (Acquire 1995). These documents are not included in the current version of HNF-SD-WM-RPT-288 (Sederburg 1997) but are being added to the required document list in the next revision. 
HNF-1901 Rev 1

\subsubsection{Facility Description}

The 242-A Evaporator is located in the 200 East Area and is used to treat dilute tank waste from the DST system by removing water and most volatile organics. The 242-A Evaporator process employs a conventional forced circulation, vacuum evaporation system to concentrate the DST System aqueous waste solution.

\subsubsection{Waste Receiving Capabilities and Limitations}

The mixed waste processed at the 242-A Evaporator is an aqueous solution containing dissolved cations and anions such as sodium, potassium, aluminum, hydroxides, nitrates, and nitrites. Small quantities of ammonia and organics also may be present. Evaporator feed specifications (Acquire 1995) have been established to perform the following.

- Maintain process operability and safety.

- Ensure that the process condensate meets LERF acceptance limits.

- Limit volatile organic emissions to regulatory limits.

- Limit the specific gravity of waste returned to the DSTs.

A process design capacity of $870,642 \mathrm{~L} /$ day with total volume capacity of $170,597 \mathrm{~L}$ is indicated in DOE/RL 90-42 (RL 1997a).

\subsubsection{Facility Discharges}

Two dilute tank waste streams are generated at the 242-A Evaporator--slurry and process condensate. The slurry stream contains finely divided solids comprising insoluble solids and crystallized salts. Most of the volatile constituents are contained in the process condensate. Other wastes generated by the 242-A Evaporator operations include decontamination solution waste and solid secondary wastes. Water normally is used as the decontamination solution, but nitric or citric acid also may be used.

Secondary waste generated during operations and maintenance work primarily comprises; but is not limited to, dry solid materials contaminated with dangerous and/or mixed waste. Radioactive and mixed radioactive solid wastes may be stored, processed, and/or disposed of at the Central Waste Complex (CWC).

\subsubsection{Programmatic and Technical Interfaces}

The 242-A Evaporator processes highly radioactive aqueous wastes generated by Hanford Site facilities. The 242-A Evaporator could be used to process highly radioactive waste returned by the Private Contractor, but the Evaporator Authorization Basis may need to be modified. Concentrated slurry waste is pumped to the DST system, and process condensate is routed to the 
LERF. The Evaporator operations are expected to have little impact on TWR\&D and Private Contractor operations. However, the Evaporator is needed in the Phase 1 mission to reduce DST waste volume and, if necessary, to reprocess waste that fails to meet the envelope criteria. Secondary waste from the Private Contractor is fed directly to the ETF/LERF and/or the TEDF.

\subsubsection{Additional Required and Supplemental Documentation}

Table 7-24 of the HNF-SD-WM-RPT-288 (Sederburg 1997) is planned to identify the primary required and supplemental documents when the document is next upgraded (scheduled for 1998). Section 7.3 of this technical baseline identifies those documents that should be part of the technical baseline including plant operating and maintenance procedures, equipment lists, safety basis, and certified vendor information.

\subsection{EFFLUENT TREATMENT FACILITY/LIQUID EFFLUENT RETENTION FACILITY}

The ETF/LERF is used to accumulate and treat low-concentration radioactive mixed aqueous wastes generated at Hanford Site facilities. The required document for the ETF and LERF is identified in HNF-SD-WM-RPT-288 (Sederburg 1997) as DOE/RL 97-03, Hanford Facility Dangerous Waste Permit Application, Liquid Effluent Retention Facility and 200 Area Effluent Treatment Facility (RL 1997b). Waste acceptance is governed by WMH-9758688, Liquid Effluent Retention Facility/Effluent Treatment Facility Treatability Envelope (Lindsey 1997).

\subsubsection{Facility Description}

The ETF/LERF area is located in the northeast corner of the 200 East Area. The LERF provides interim storage and treatment of the 242-A Evaporator process condensate and dilute aqueous waste streams from other generating units at the Hanford Site until further treatment can be conducted at the 200 East Area ETF. Pipelines are being installed between the Private Contractor facilities and the ETF/LERF (see Section 5.0 of this document). Treatment in the LERF comprises flow and $\mathrm{pH}$ equalization in accordance with the treatment surface impoundment exemption of 40 CFR 268, "Land Disposal Restrictions," Section 268.4, "Treatment surface impoundment exemption."

The 200 East Area ETF is a flexible treatment system that provides treatment for contaminants anticipated in process condensate from the 242-A Evaporator and from other Hanford facility waste streams. The treatment process includes filtration, $\mathrm{pH}$ adjustment, ultraviolet oxidation, hydrogen peroxide decomposition, degasification, reverse osmosis, ion exchange, effluent quality verification in tanks, evaporation, concentration, and thin-film drying. The treated effluent is stored in three verification tanks and is sampled to determine if the effluent meets required discharge standards. 


\subsubsection{Waste Receiving Capabilities and Limitations}

The ETF/LERF waste receiving capabilities and limitations for the Private Contractor are provided in WMH-9758688 (Lindsey 1997), which is a required element in ICD-06 (see Section 5.0 of this document). A description of the alternatives available for meeting waste acceptance requirements is provided in WMH-9758688 (Lindsey 1997). A waste profile must be developed and negotiated between the ORP/RPP team and the Private Contractor. This ensures that regulatory and process limits are met while providing maximum receipt composition flexibility. Total design and process capacity of the ETF/LERF are available in DOE/RL 97-03 (RL 1997b).

\subsubsection{Facility Discharges}

The LERF discharges to the ETF. The ETF generates a treated effluent stream that is accumulated in verification tanks. When the treated effluent meets the "delisting" criteria of 40 CFR 261, "Identification and Listing of Hazardous Waste;" WAC 173-216, "State Waste Discharge Permit Program;" and Permit No. ST-4500, State Waste Discharge Permit for the "200 Area Effluent Treatment Facility. (ETF) (Ecology 1995a), it is released as a nondangerous waste to the State Approved Land Disposal Site (SALDS) in the 200 West Area. If the sample analysis of the effluent in the verification tanks does not meet the discharge standards, the effluent is returned to the system for further treatment.

Two nonaqueous waste streams are generated during the operation of the ETF: (1) a solid waste stream from the secondary treatment process and (2) a solid waste stream comprising general trash from maintenance and operations activities. The first solid waste stream includes contaminants removed from aqueous waste. The contaminants and treatment byproducts are concentrated into a powder that is packaged and transferred to the CWC for storage at the Low-Level Burial Grounds or disposal at the Environmental Restoration Disposal Facility in accordance with applicable waste acceptance criteria.

\subsubsection{Programmatic and Technical Interfaces}

The ETF/LERF interfaces with the Private Contractor are contained in BNFL-5193-ID-06 (BNFL 1998e) (see Section 5.0 of this document). Other technical interfaces are contained in HNF-SD-SM-RPT-288 (Sederburg 1997).

\subsubsection{Additional Required and Supplemental Documentation}

A list of documents specific to the 200 East Area Liquid Waste Processing Facility Complex including the LERF and the ETF is provided in HNF-SD-SM-RPT-288 (Sederburg 1997). These documents include permits, conduct of operations evaluations, memoranda of understanding, and general acceptance criteria. 


\section{$7.4 \quad 200$ EAST AREA TREATED EFFLUENT DISPOSAL FACILITY}

The 200 East Area TEDF currently receives treated and/or innocuous nonradioactive, nondangerous liquid effluent from several 200 Areas generators. This type of waste also is received from the Private Contractor in accordance with BNFL-5193-D-05 (BNFL 1998d). BNFL-5193-ID-05, which is a technical baseline document (see Section 5.0 of this document), requires that the Private Contractor meet the requirements of HNF-SD-W049H-ICD-001, 200 Area Treated Effluent Disposal Facility Interface Control (Crane 1997). HNF-SD-W049H-ICD001 and BNFL-5193-ID-05 are the primary sources of information for this section.

\subsubsection{Facility Description}

The 200 East Area TEDF comprises disposal ponds and associated piping systems, supporting structures, components, and instrumentation. The disposal ponds are located east of the ETF/LERF in the 200 East Area. Because the 200 East Area TEDF does not have any treatment or retention capacity, strict control at the generating facility interface is essential to operate in compliance with the requirements of WAC 173-216, the State Waste Discharge Permit; the Hanford Site requirements; and good engineering practices.

\subsubsection{Waste Receiving Capabilities and Limitations}

The 200 East Area TEDF currently receives waste from several sources including the Plutonium Finishing Plant, 222-S facility, T Plant, 284-W and 284-E Power Plants, B Plant, the 241-A Tank Farm, the 244-AR Sludge Vault Storage and Processing Facility, and the 242-A Evaporator. Waste streams include facility wastewater, chemical sewers, cooling water, and steam condensate. Strict pH limits must be maintained. Each source also is limited in maximum flow rate. The 200 East Area TEDF chemical concentrations must meet Permit No. ST-4502, State Waste Discharge Permit 200 Area Treated Effluent Disposal Facility (Project W-049H) (Ecology 1995b) limits.

\subsubsection{Facility Discharges}

The 200 East Area TEDF discharges to the SALDS in 200 East Area, which is discussed in Section 7.5.

\subsubsection{Programmatic and Technical Interfaces}

The primary interface document between this facility and Hanford source generators is HNF-SD-W049H-ICD-001 (Crane 1997). For the Private Contractor, BNFL-5193-ID-05 (BNFL 1998d), regarding nonradioactive, nondangerous liquid effluent for Phase 1 privatization, is the governing document and requires compliance with HNF-SD-W049H-ICD-001 (Crane 1997). 


\subsection{STATE-APPROVED LAND DISPOSAL SITES}

The SALDS are rectangular drain fields that receive treated effluent in accordance with permit requirements. Two SALDS in the 200 Areas receive discharge liquid from the ETF and TEDF. The SALDS that receives liquids from the ETF is located north of the 200 West Area. Discharges to this SALDS are governed by Permit No. ST-4500 (Ecology 1995a). The SALDS that receives liquids from the TEDF is located in the east portion of 200 East Area. These discharges are governed by Permit No. ST-4502 (Ecology 1995b). Acceptance criteria for the ETF and TEDF are written, in part, to ensure that these permit requirements are met.

\subsection{CENTRAL WASTE COMPLEX}

The CWC is an existing and planned series of facilities designed to centralize the management of solid-waste operations at the Hanford Site. The CWC is managed as part of the Solid Waste Program. The Solid Waste Program has a technical baseline description, WHC-SD-WM-RPT-060, Solid Waste Program Technical Baseline Description (Sederburg 1996), which is included in HNF-SD-WM-RPT-288 (Sederburg 1997). (An additional important document is DOE/RL 91-17, Hanford Central Waste Complex Radioactive Mixed Waste Storage Facility Dangerous Waste Permit Application, Volumes I and II [RL 1991b].) Interfaces with the Private Contractor are controlled through BNFL-5193-ID-03 (BNFL 1998c) (see Section 5.0 of this document).

\subsubsection{Facility Description}

The CWC comprises multiple facilities for storage of radioactive and mixed waste while the waste awaits processing or certification for final disposal. Treatment of waste at the CWC includes the absorption and solidification of free liquids and the neutralization of corrosive materials. As additional treatment processes and disposal facilities become available, WMH treats and repackages stored waste as required for disposal. Treatment processes include commercial thermal treatment as described in HNF-SD-WM-RPT-288 (Sederburg 1997). WMH also is entering into contracts for various commercial treatments and repackaging.

\subsubsection{Waste Receiving Capabilities and Limitations}

Waste acceptance criteria for the CWC are contained in HNF-EP-0063, Hanford Site Solid Waste Acceptance Criteria (WMH 1998). BNFL-5193-ID-03 requires compliance with these criteria. Waste packages are transported in trucks directly to the CWC from generating facilities. Incoming waste destined for storage within the CWC usually is contained in 208-L (55-gal) drums. The CWC receives and inspects waste containers at the Waste Receiving and Staging Area or occasionally at the storage buildings.

To ensure that adequate long-term storage capacity exists, several solid-waste-generation studies have been performed including HNF-EP-0918 (Valero 1997). This report estimates that the peak volume at CWC, and the peak volume from the HLW and LAW immobilization activities, occur approximately in 2014. Peak volumes are below the rated maximum permitted capacity. The 
total required storage and process capacity for the CWC is identified in DOE/RL 91-17 (RL 1991c).

\subsubsection{Facility Discharges}

For all solid waste and mixed materials, it is estimated that some equipment and materials are released for unrestricted use; TRU waste is sent to the Waste Isolation Pilot Project; hazardous waste is sent to an offsite commercial facility for treatment and/or disposal, is placed in longterm storage awaiting development of treatment systems, or otherwise is disposed of at the Hanford Site (Sederburg 1997).

\subsubsection{Programmatic and Technical Interfaces}

The CWC interfaces between the Private Contractor and the government contractors are defined in BNFL-5193-ID-03 (BNFL 1998c) (see Section 5.0 of this document). Other interfaces are identified in HNF-SD-WM-RPT-288 (Sederburg 1997), WHC-SD-WM-RPT-060 (Sederburg 1996), and WHC-SD-WM-PICD-003 (Duncan 1995).

\subsubsection{Additional Required and Supplemental Documentation}

A list of the primary required and supplemental documents applicable to the CWC is provided in HNF-SD-WM-RPT-288 (Sederburg 1997). This list includes plant operating and maintenance procedures, equipment lists; certified vendor information, criticality reports, permits; and safety bases. 


\subsection{UTILITY SUPPORT}

DYN provides the infrastructure support (utilities, transportation, general-purpose facilities, and sitewide services) for the Hanford Site, including the RPP and the Private Contractor. This section briefly describes the scope of utility support to the TWR\&D mission. Table 8 lists the technical baseline documents identified to date for utility support, along with summaries of the source information for each listed document. Most of the information in this section is from these technical baseline documents and HNF-SP-1169-98, FY 1998 Annual Work Plan for Infrastructure Programs WBS 6.17 (Dallas 1997).

Table 8. Utilities Support Documents and Designated Source Documents.

\begin{tabular}{|l|c|c|l|}
\hline \multicolumn{1}{|c|}{ Document } & $\begin{array}{c}\text { Maintained } \\
\text { current?* }\end{array}$ & $\begin{array}{c}\text { Appendix } \\
\text { number }\end{array}$ & \multicolumn{1}{|c|}{ Source information } \\
\hline $\begin{array}{l}\text { BNFL-5193-ID-01, Interface } \\
\text { Control Document Between } \\
\text { DOE and BNFL Inc. for Raw } \\
\text { Water (BNFL 1998a) }\end{array}$ & Yes & D.1 & $\begin{array}{l}\text { Establishes interfaces with Private } \\
\text { Contractor for the delivery and use } \\
\text { of raw water. }\end{array}$ \\
\hline $\begin{array}{l}\text { BNFL-5193-ID-02, Interface } \\
\text { Control Document Between } \\
\text { DOE and BNFL Inc. for } \\
\text { Potable Water (BNFL 1998b) }\end{array}$ & Yes & D.2 & $\begin{array}{l}\text { Establishes interfaces with Private } \\
\text { Contractor for the delivery and use } \\
\text { of potable water. }\end{array}$ \\
\hline $\begin{array}{l}\text { BNFL-5193-ID-11, Interface } \\
\text { Control Document Between } \\
\text { DOE and BNFL Inc. for } \\
\text { Electricity (BNFL 1998h) }\end{array}$ & Yes & D.8 & $\begin{array}{l}\text { Establishes interfaces with Private } \\
\text { Contractor with respect to } \\
\text { electricity delivery to Private } \\
\text { Contractor facilities during Phase 1 } \\
\text { privatization activities. }\end{array}$ \\
\hline $\begin{array}{l}\text { BNFL-5193-ID-12, Interface } \\
\text { Control Document Between } \\
\text { DOE and BNFL Inc. for } \\
\text { Roads and Rails } \\
\text { (BNFL 1998i) }\end{array}$ & Yes & D.9 & $\begin{array}{l}\text { Establishes interfaces with Private } \\
\text { Contractor for road use during } \\
\text { Phase 1 privatization activities and } \\
\text { establishes that there is no direct } \\
\text { rail. }\end{array}$ \\
\hline
\end{tabular}

*Is the document to be maintained current per HNF-1900, Tank Waste Remediation System Configuration Management Plan (Vann et al. 1998)?

DOE $=$ U.S. Department of Energy.

The DYN Site Infrastructure mission is to provide safe, quality infrastructure services to the Hanford Site community that meet identified goals (Dallas 1997). Specific infrastructure services that DYN provides to the RPP team include site fabrication services; crane and rigging services; general-purpose facility management and maintenance services; utilities maintenance and operations; materials management; laboratory operations support; calibration and 
nondestructive examinations services; transportation and nonradioactive and solid-waste handling; ES\&H and quality assurance support; emergency services, including management of the Hanford Fire Department and Emergency Preparedness; and management of the Landlord Programs. Emergency services and Landlord Programs are covered by separate annual work plans.

Infrastructure support to the Private Contractor is addressed in privatization ICDs (see Table 5 and Section 5.0 of this document). DYN is responsible for providing the utilities (e.g., water, electricity), but is not responsible for installing the infrastructure or Private Contractor roads. 


\subsection{CLOSURE}

Dangerous waste and radiologically contaminated treatment, storage, and disposal facilities supporting the TWR\&D mission require closure following the completion of their service. Closure is governed by DOE, state, and Federal regulations, which in most cases require comprehensive closure plans. Future site usage plans and guidance have been developed to guide decision making about postclosure site conditions. Tank farm closure and the RPP team facilities are outside the Phase 1 mission. For this technical baseline summary, the most important closure information relates to privatization efforts and ILAW and IHLW storage and disposal systems. Information on these items is provided in this section, followed by information on closure of the general tank farm system and support facilities. Technical baseline documents are provided in Table 9. No new technical baseline documents are identified in this section.

Table 9. Summary of Source Tank Closure/Other Interfaces.

\begin{tabular}{|c|c|c|c|}
\hline Document & $\begin{array}{l}\text { Maintained } \\
\text { current? }^{2}\end{array}$ & Appendix & Source information \\
\hline $\begin{array}{l}\text { HNF-SD-WM-MAR-008, River } \\
\text { Protection Project Mission } \\
\text { Analysis Report (Acree 1998) }\end{array}$ & Yes & A.1 & $\begin{array}{l}\text { Establishes acceptable end-state } \\
\text { conditions for closure. }\end{array}$ \\
\hline $\begin{array}{l}\text { BNFL-5193-ID-10, Interface } \\
\text { Control Document Between } \\
\text { DOE and BNFL Inc. for } \\
\text { Deactivated Facility and Site } \\
\text { (BNFL 1998g) }\end{array}$ & Yes & D.7 & $\begin{array}{l}\text { Establishes interfaces with Private } \\
\text { Contractor for the facility } \\
\text { deactivation and site turnover to } \\
\text { DOE following completion of } \\
\text { Privatization Phase } 1 \text { activities. }\end{array}$ \\
\hline $\begin{array}{l}\text { HNF-SD-WM-RPT-288, Waste } \\
\text { Management Project Technical } \\
\text { Baseline Description, } \\
\text { (Sederburg 1997) }\end{array}$ & Yes & F.1 & $\begin{array}{l}\text { Source for information relating to } \\
\text { WMH activities, including } \\
\text { ETF/LERF, 242-A Evaporator, } \\
\text { Central Waste Complex, and } \\
\text { 222-S Laboratory. }\end{array}$ \\
\hline
\end{tabular}

\footnotetext{
${ }^{2}$ Is the document to be maintained current per HNF-1900, Tank Waste Remediation System Configuration Management Plan (Vann et al. 1998)?

${ }^{\mathrm{b}}$ Analytical services-related interface documents have not been developed to address interfaces between the Private Contractor and WMH.

DOE = U.S. Department of Energy.

ETF = Effluent Treatment Facility.

LERF = Liquid Effluent Retention Facility.

$\mathrm{WMH}=$ Waste Management Federal Services of Hanford, Inc.
}

\subsection{PRIVATE CONTRACTOR FACILITIES}

The Private Contractor is responsible for turning its facilities over to the ORP/RPP team after it has deactivated the systems, as required in the privatization contract (RL 1998). Deactivated 
Private Contractor facilities are added to the inventory of Hanford Site facilities under transition and decontamination and decommissioning projects. Decisions regarding the final closure of Private Contractor facilities are made once closure plans are developed and the DOE/EIS-0189 (DOE and Ecology 1996) is updated or a separate environmental impact statement is written. BNFL-5193-ID-10 (BNFL 1998g) (see Section 5.0) provides the interface requirements for this activity.

\subsection{IMMOBILIZED WASTE FACILITIES}

After completion of the TWR\&D mission, including Phases 1 and 2, surface facilities for storing ILAW and IHLW are decontaminated (if necessary), razed, and/or filled to prevent subsidence. A standard Hanford Site surface barrier is assumed to be used as cover for the ILAW disposal vaults and, if necessary, for the stabilized surface facilities (DOE/RW-0351P, Waste Acceptance - Systems Requirement Document [DOE 1996b]).

\subsubsection{Immobilized Low-Activity Waste Facilities}

The ILAW facilities are maintained until all ILAW is received for ultimate disposal. At least 30 years of postclosure monitoring is provided, after which an approved closure plan is implemented and appropriate barriers are installed. Preparation of the ILAW facility closure plan and associated decision making (e.g., Natiönal Environmental Policy Act of 1969 [NEPA]) documentation is at least seven years in the future.

\subsubsection{Immobilized High-Level Waste Facilities}

Because IHLW is stored in the CSB, which is managed by the SNF Project, the TWR\&D organization is responsible as a "user" to ensure that the designated storage location (Vaults 2 and 3), once empty, is closed in a manner consistent with the CSB closure plan, at the direction of the SNF Project. Preparation of the CSB closure plan and associated decision-making documentation (e.g., NEPA) for closure of the CSB is at least seven years in the future.

\subsection{TANK FARM SYSTEMS}

A summary of tank farm closure requirements is contained in HNF-SD-WM-MAR-008 (Acree 1998). The information source for the closure requirements is 62 FR 8693, "Record of Decision for the Tank Waste Remediation System, Hanford Site, Richland, WA." Acceptable end state conditions for the tank farm systems include the following.

- Tank waste_LAW is immobilized and disposed of onsite.

- Tank waste-HLW is immobilized and safely stored onsite for eventual disposal at the HLW geologic repository. 
- Storage tank systems-SSTs, DSTs, miscellaneous underground storage tanks, and associated systems are closed in accordance with decisions on tank farm end state to be reached under a NEPA closure process. This process addresses final disposition of the tanks, associated equipment, soils, and groundwater and integrates tank farm closure with tank waste remediation and other remedial action activities (62 FR 8693).

- ${ }^{137} \mathrm{Cs}$ and ${ }^{90} \mathrm{Sr}$ - The ${ }^{137} \mathrm{Cs} /{ }^{90} \mathrm{Sr}$ capsules either are overpacked and shipped to the highlevel nuclear waste repository for disposal or are disassembled. The ${ }^{137} \mathrm{Cs}$ and ${ }^{90} \mathrm{Sr}$ salts removed from the capsules would then be blended into the high-level waste stream for immobilization.

- Facilities-Facilities are decontaminated and decommissioned and closed by the RPP or turned over to the Environmental Restoration Project.

- Other-Several areas termed "non-facility" are closed (e.g., cribs, unplanned release sites).

\subsection{OTHER PROJECT HANFORD MANAGEMENT CONTRACT TEAM SUPPORTING FACILITIES}

The other PHMC team supporting facilities include the 222-S Laboratory, 242-A Evaporator, the .ETF/LERF, SALDS, CWC, Low-Level Waste Burial Grounds, and 200 East Area TEDF. These facilities are operated by WMH and generally are closed in accordance with closure plans, RCRA permits, and other documents established and identified in the HNF-SD-WM-RPT-288 (Sederburg 1997). In most cases, closure plans have not been definitively developed because of the long life expectancy of these facilities. Closure sections in existing RCRA permits generally identify the need for clean closure, with respect to dangerous waste contamination that results from operation, within a limited time unless additional regulatory approval is obtained. 
HNF-1901 Rev 1

This page intentionally left blank. 
HNF-1901 Rev 1

\section{APPENDIX A}

TANK WASTE RETRIEVAL AND DISPOSAL MISSION SCOPE DOCUMENTS 
HNF-1901 Rev 1

This page intentionally left blank. 
HNF-1901 Rev 1

\begin{tabular}{|l|l|}
\hline Assigned Document Number & Maintained Current? \\
\hline A.1 & Yes \\
\hline Document Name \\
Hanford Site Technical Baseline Database (HSTD) \\
\hline Responsible Organization \\
LMHC \\
\hline Status of Preparation/Revision \\
This database is continually revised to include information (e.g., requirements) as developed. \\
\hline Source Information Designation \\
Defines sitewide technical requirements for conducting Hanford Site work. \\
\hline Brief Summary of Content \\
The HSTD will contain all information necessary to specify the physical, technical work on the \\
River Protection Project (RPP). \\
Inter-related documents (successors and predecessors) \\
The predecessor document is the Tank Waste Remediation System Mission Analysis Report \\
RPP.
\end{tabular}




\begin{tabular}{|l|l|}
\hline Assigned Document Number & Maintained Current? \\
\hline A.2 & Yes \\
\hline Document Name \\
WHC-SD-MP-SRID-001, Rev. 1, High Level Waste Storage Tank Farms/242-A Evaporator \\
Standards/Requirements Identification Document (Biebesheimer 1996) \\
\hline Responsible Organization \\
LMHC \\
\hline Status of Preparation/Revision \\
Revision 2 in progress. \\
\hline Source Information Designation \\
Identifies environmental, safety, and health (ES\&H) requirements for conducting RPP work. \\
\hline Brief Summary of Content \\
Identifies ES\&H requirements to protect the public, worker, and the environment. It is divided \\
into 20 functional areas (e.g., Management Systems, Quality Assurance, Configuration \\
Management).
\end{tabular}




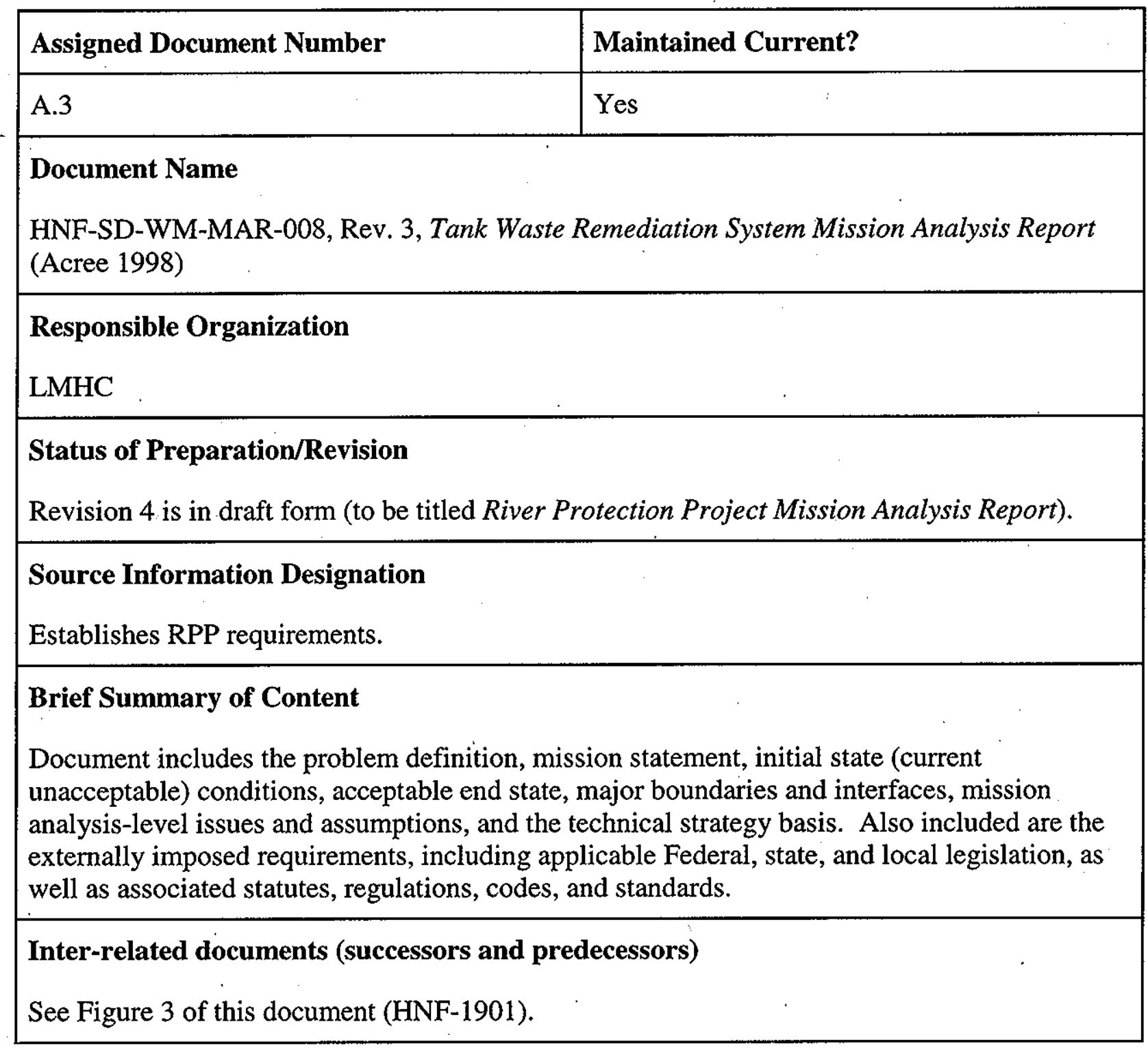


HNF-1901 Rev 1

This page intentionally left blank. 
HNF-1901 Rev 1

APPENDIX B

WASTE FEED DELIVERY DOCUMENTS 


\section{HNF-1901 Rev 1}

This page intentionally left blank. 
HNF-1901 Rev 1

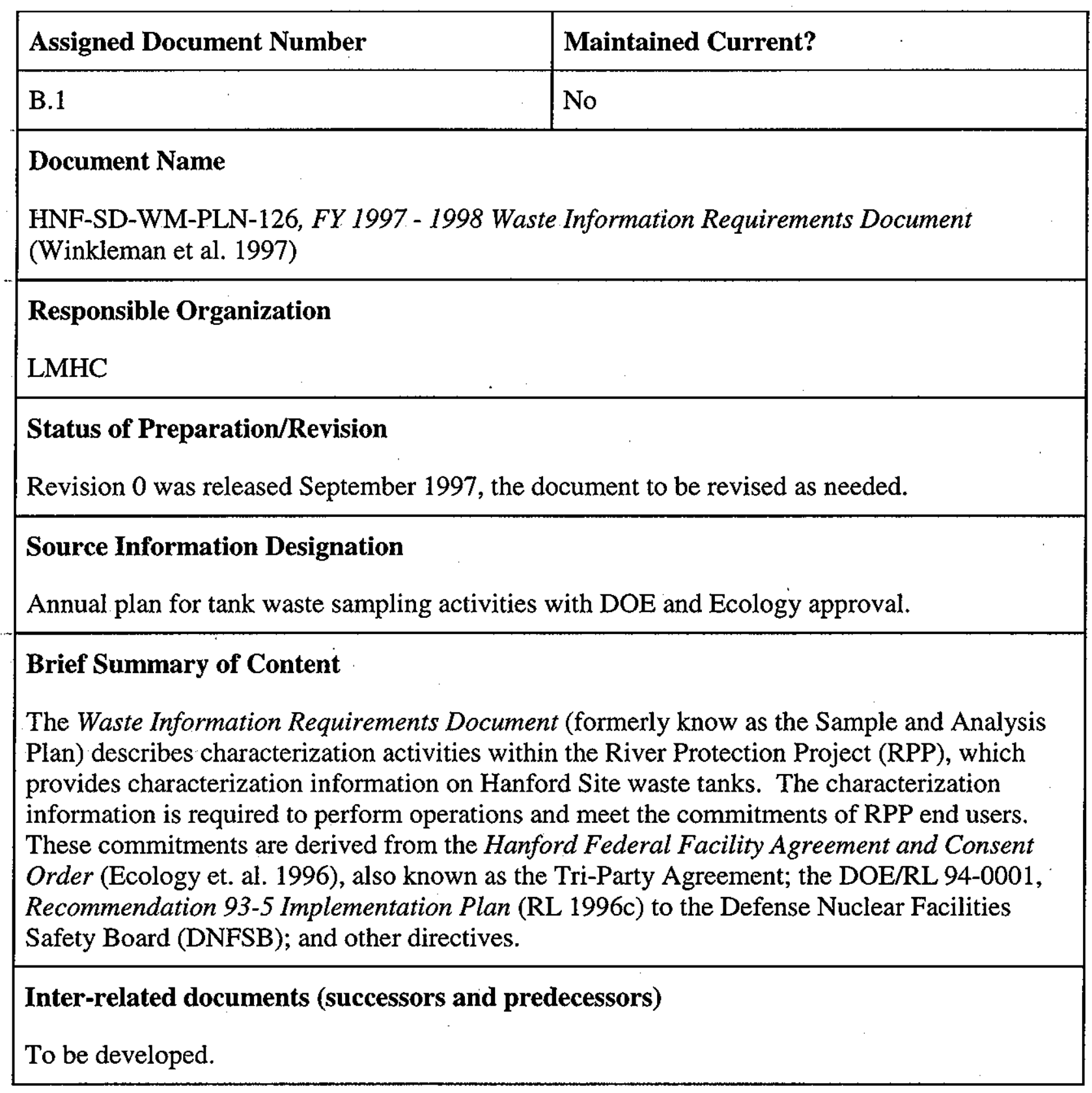


HNF-1901 Rev 1

\begin{tabular}{|c|c|}
\hline Assigned Document Number & Maintained Current? \\
\hline B. 2 & Yes \\
\hline \multicolumn{2}{|l|}{ Document Name } \\
\hline \multicolumn{2}{|c|}{$\begin{array}{l}\text { HNF-SD-WM-TI-740, Standard Inventories of Chemicals and Radionuclides in Hanford Site } \\
\text { Tank Wastes (Kupfer et al. 1999) }\end{array}$} \\
\hline \multicolumn{2}{|l|}{ Responsible Organization } \\
\hline \multicolumn{2}{|l|}{ LMHC } \\
\hline \multicolumn{2}{|l|}{ Status of Preparation/Revision } \\
\hline \multicolumn{2}{|c|}{ Revision 0 was released, the document to be revised as needed. } \\
\hline \multicolumn{2}{|l|}{ Source Information Designation } \\
\hline \multicolumn{2}{|c|}{ Best-basis inventory of the chemicals and radiological contents of tank farm wastes. } \\
\hline \multicolumn{2}{|l|}{ Brief Summary of Content } \\
\hline \multicolumn{2}{|c|}{$\begin{array}{l}\text { This report presents work performed to date to establish standard global and tank-by-tank } \\
\text { component inventory estimates. This work includes global inventory reconciliations for } 26 \\
\text { nonradioactive components and } 46 \text { radionuclides that account for approximately } 99 \text { percent of } \\
\text { the total tank waste inventory. To ensure that inventory values resulting from these } \\
\text { evaluations are technically defensible and reproducible, every attempt is being made to } \\
\text { document the basis (i.e., originating sources of assumptions, data, and background information } \\
\text { that support these values). }\end{array}$} \\
\hline \multicolumn{2}{|c|}{ Inter-related documents (successors and predecessors) } \\
\hline To be developed. & \\
\hline
\end{tabular}




\begin{tabular}{|c|c|}
\hline Assigned Document Number & Maintained Current? \\
\hline B.3 & Yes \\
\hline \multicolumn{2}{|c|}{$\begin{array}{l}\text { Tank Characterization Report for Tank } 241-\mathrm{XX}-\mathrm{XXX} \text { (where } \mathrm{X} \text { varies for each of the } 177 \\
\text { underground tanks at Hanford): Best-Basis Inventory, HNF-SD-WM-ER-XXX (where XXX } \\
\text { numbers shown in source information below). Authors vary by report. See Appendix G of } \\
\text { this document (HNF-1901) for complete reference information. }\end{array}$} \\
\hline \multicolumn{2}{|l|}{ Responsible Organization } \\
\hline \multicolumn{2}{|l|}{ Status of Preparation/Revision } \\
\hline $\begin{array}{l}\text { Source Information Designati } \\
\text { Best-basis inventories for the } 17\end{array}$ & Ts and SSTs. \\
\hline \multicolumn{2}{|c|}{$\begin{array}{l}\text { (XXX in the document number }=357,358,359,360,361,362,363,364,365,366,367,368,369,370,371, \\
372,382,402,405,406,407,408,409,410,411,453,454,455,466,470,471,472,473,474,475,476,477,478, \\
479,480,481,482,483,484,485,486,488,489,503,528,533,535,539,540,541,544,545,549,550,551,552, \\
554,558,559,566,569,570,572,581,578,582,584,587,589,591,593,596,597,598,599,600,601,602,605, \\
608,609,611,613,614,615,616,617,618,627,630,636,637,638,639,640,641,642,643,644,645,646,647, \\
648,649,650,651,652,653,654,655,656,657,658,659,660,661,662,663,666,667,668,669,670,671,672, \\
673,674,675,677,678,679,681,682,683,684,685,686,687,689,690,699,700,701,702,703,704,705,706, \\
707,708.709,710,711,712,713,714,715,716,717,718,719,720,721,722,723,724,725,726,727,278,729, \\
732)\end{array}$} \\
\hline \multicolumn{2}{|c|}{$\begin{array}{l}\text { These documents report the effort to provide waste inventory estimates that will serve as } \\
\text { standard characterization source terms for the various waste management activities. As part of } \\
\text { this effort, evaluations of the available information for all } 177 \text { tanks were performed, and a } \\
\text { best-basis inventory for each tank was established. This work follows the methodology that } \\
\text { was established by the standard inventory task identified in B.2. }\end{array}$} \\
\hline \multicolumn{2}{|c|}{ Inter-related documents (successors and predecessors) } \\
\hline
\end{tabular}




\section{HNF-1901 Rev 1}

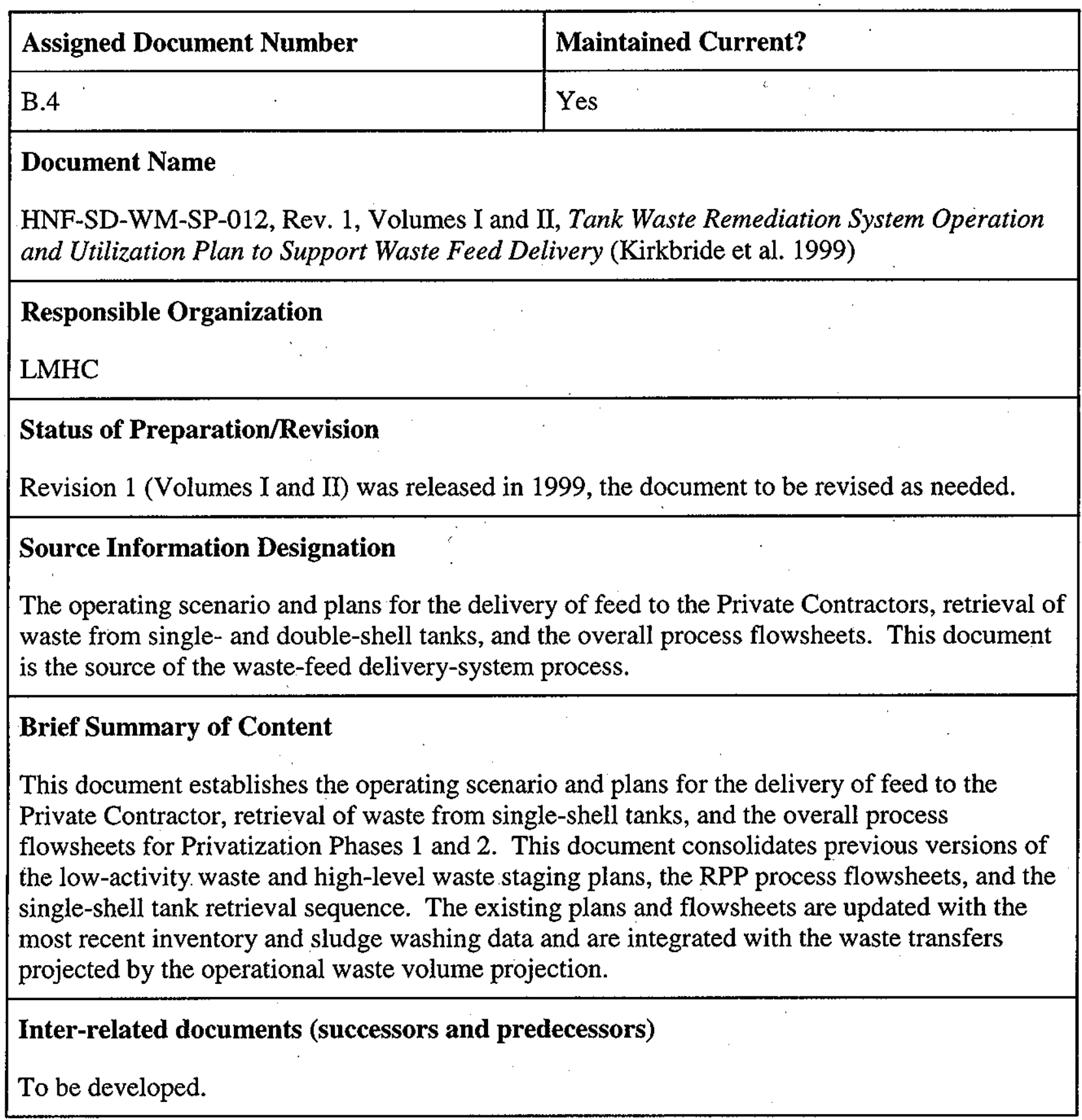


HNF-1901 Rev 1

\begin{tabular}{|c|c|}
\hline Assigned Document Number & Maintained Current? \\
\hline B.5 & Yes \\
\hline \multicolumn{2}{|c|}{$\begin{array}{l}\text { Document Name } \\
\text { HNF-2401, Waste Feed Delivery Environmental Permits and Approvals Plan } \\
\text { (Papp et al. 1998) }\end{array}$} \\
\hline \multicolumn{2}{|l|}{$\begin{array}{l}\text { Responsible Organization } \\
\text { LMHC }\end{array}$} \\
\hline \multicolumn{2}{|c|}{$\begin{array}{l}\text { Status of Preparation/Revision } \\
\text { Revision 0 was released July 6, } 1998 .\end{array}$} \\
\hline \multicolumn{2}{|c|}{$\begin{array}{l}\text { Source Information Designation } \\
\text { Description of environmental actions that may affect waste feed delivery activities. }\end{array}$} \\
\hline \multicolumn{2}{|c|}{$\begin{array}{l}\text { Brief Summary of Content } \\
\text { The plan outlines alternative approaches to satisfying environmental standards and regulations. } \\
\text { It describes the strategies needed to acquire permits and other regulatory approvals needed for } \\
\text { waste feed delivery activities to proceed. }\end{array}$} \\
\hline $\begin{array}{l}\text { Inter-related documents (succ } \\
\text { HNF-1773, Rev. 2, River Protec }\end{array}$ & vironmental Program Plan (Allen 1999). \\
\hline
\end{tabular}


HNF-1901 Rev 1

\begin{tabular}{|l|l|}
\hline Assigned Document Number & Maintained Current? \\
\hline B.6 & Yes \\
\hline $\begin{array}{l}\text { Document Name } \\
\text { HNF-SD-WM-TRD-007, System Specification for the Double-Shell Tank System } \\
\text { (Grenard et al. 1999) }\end{array}$ \\
\hline Responsible Organization \\
LMHC \\
\hline Status of Preparation/Revision \\
Draft Revision E (1998) will become Revision 0 when released in 1999. \\
\hline $\begin{array}{l}\text { Source Information Designation } \\
\text { High-level definition of the specifications for equipment to be used in the double-shell tank } \\
\text { system. }\end{array}$ \\
\hline Brief Summary of Content \\
The specification document establishes the functional, performance, design, development, \\
interface, and test requirements for the double-shell tank system segment of the River \\
Protection Project.
\end{tabular}


HNF-1901 Rev 1

\begin{tabular}{|c|c|}
\hline Assigned Document Number & Maintained Current? \\
\hline B.7 & Yes \\
\hline \multicolumn{2}{|l|}{ Document Names } \\
\hline \multicolumn{2}{|c|}{ Component specifications for the Double-Shell Tank System: } \\
\hline \multicolumn{2}{|c|}{ HNF-4153, Level 2 Specification for the Double-Shell Tank Confinement System (in work) } \\
\hline \multicolumn{2}{|c|}{ HNF-4154, Level 2 Specification for the Double-Shell Tank Waste Sampling System (in work) } \\
\hline \multicolumn{2}{|c|}{$\begin{array}{l}\text { HNF-4155, Level } 2 \text { Specification for the Double-Shell Tank Monitoring and Control System } \\
\text { (in work) }\end{array}$} \\
\hline \multicolumn{2}{|c|}{$\begin{array}{l}\text { HNF-4157, Level } 2 \text { Specification for the Double-Shell Tank Utility System (NHC 1999a, } \\
\text { December) }\end{array}$} \\
\hline \multicolumn{2}{|c|}{$\begin{array}{l}\text { HNF-5196 Level } 2 \text { Specification for the Double-Shell Tank Ventilation System (NHC 1999b, } \\
\text { October) }\end{array}$} \\
\hline \multicolumn{2}{|c|}{$\begin{array}{l}\text { HNF-4159 Level } 2 \text { Specification for the Double-Shell Tank Maintenance and Recovery System } \\
\text { (in work) }\end{array}$} \\
\hline \multicolumn{2}{|c|}{$\begin{array}{l}\text { HNF-4160 Level } 2 \text { Specification for the Double-Shell Tank Transfer Valving System } \\
\text { (NHC 1999c) }\end{array}$} \\
\hline \multicolumn{2}{|c|}{$\begin{array}{l}\text { HNF-4161 Level } 2 \text { Specification for the Double-Shell Tank Transfer Piping System } \\
\text { (NHC 1999d) }\end{array}$} \\
\hline \multicolumn{2}{|c|}{$\begin{array}{l}\text { HNF-4162 Level } 2 \text { Specification for the Double-Shell Tank Transfer Pump System } \\
\text { (NHC'1999e) }\end{array}$} \\
\hline \multicolumn{2}{|c|}{$\begin{array}{l}\text { HNF-4163 Level } 2 \text { Specification for the Double-Shell Tank Caustic and Diluent Transfer } \\
\text { System (NHC 1999f, November) }\end{array}$} \\
\hline \multicolumn{2}{|c|}{$\begin{array}{l}\text { HNF-4164 Level } 2 \text { Specification for the Double-Shell Tank Mixer Pump System (NHC 1999g, } \\
\text { October) }\end{array}$} \\
\hline \multicolumn{2}{|l|}{ Responsible Organization } \\
\hline \multicolumn{2}{|l|}{ LMHC } \\
\hline \multicolumn{2}{|l|}{ Status of Preparation/Revision } \\
\hline ay per fisca & \\
\hline
\end{tabular}




\section{HNF-1901 Rev 1}

\section{Source Information Designation}

N/A

Brief Summary of Content

Overall process design criteria for new and modified equipment supporting the waste feed delivery system.

Inter-related documents (successors and predecessors)

To be developed. 
HNF-1901 Rev 1

\begin{tabular}{|c|c|}
\hline Assigned Document Number & Maintained Current? \\
\hline B. 8 & Yes \\
\hline \multicolumn{2}{|c|}{$\begin{array}{l}\text { Document Name } \\
\text { Technical Baseline Documents for Project W-314 }\end{array}$} \\
\hline \multicolumn{2}{|l|}{$\begin{array}{l}\text { Responsible Organization } \\
\text { LMHC }\end{array}$} \\
\hline \multicolumn{2}{|l|}{$\begin{array}{l}\text { Status of Preparation/Revision } \\
\text { Various }\end{array}$} \\
\hline \multicolumn{2}{|c|}{$\begin{array}{l}\text { Source Information Designation } \\
\text { Technical baseline documents related to the W-314 Project, Tank Farm Restoration and Safe } \\
\text { Operations. }\end{array}$} \\
\hline \multicolumn{2}{|c|}{$\begin{array}{l}\text { The project technical baseline documents are divided into } 19 \text { categories as identified below. } \\
\text { The categories were developed in accordance with applicable engineering plans and } \\
\text { procedures. }\end{array}$} \\
\hline \multicolumn{2}{|l|}{ 1. Functional Design Criteria } \\
\hline \multicolumn{2}{|c|}{$\begin{array}{l}\text { WHC-SD-W314-DRD-001, Preliminary Design Requirements Document for Project W-314, } \\
\text { Tank Farm Restoration and Safe Operations (Boes 1996b) }\end{array}$} \\
\hline \multicolumn{2}{|l|}{ 2. Conceptual Design Report } \\
\hline \multicolumn{2}{|c|}{$\begin{array}{l}\text { WHC-SD-W314-CDR-001, Rev. 1, Conceptual Design Report for Tank Farm Restoration } \\
\text { and Safe Operations, Project W-314 (Boes 1996a) }\end{array}$} \\
\hline \multicolumn{2}{|l|}{ 3. Alternate Design Study } \\
\hline \multicolumn{2}{|c|}{$\begin{array}{l}\text { HNF-SD-W314-AGA-007, Alternative Generation and Analysis Report, Tank Farm } \\
\text { Monitoring and Master Pump Shutdown, Tank Farm Restoration and Safe Operation, W-314 } \\
\text { (Jacobson 1997) }\end{array}$} \\
\hline \multicolumn{2}{|l|}{ 4. Final Design Report } \\
\hline
\end{tabular}




\section{HNF-1901 Rev 1}

5. Acceptance Test Plan

HNF-SD-W314-TEP-001, Test and Evaluation Plan for Project W-314 Tank Farm Restoration and Safe Operation (Hammers 1999b)

HNF-1733, Project W-314 Specific Test and Evaluation Plan 241-AN-A Valve Pit (Hammers 1999a)

HNF-XXXX through HNF-XXXX TBD (16 more STEPs are scheduled for release)

6. Operational Test Plan

HNF-SD-W314-TEP-001, Test and Evaluation Plan for Project W-314 Tank Farm Restoration and Safe Operation (Hammers 1999b)

HNF-1733, Project W-314 Specific Test and Evaluation Plan 241-AN-A Valve Pit (Hammers 1999a)

HNF-XXXX through HNF-XXXX TBD (16 more STEPs are scheduled for release)

7. Operational Readiness Review/Acceptance Beneficial Use

HFN-SD-W314-ABU-001, Project W-314 Master Pump Shutdown Upgrade Acceptance for Beneficial Use (Warnick 1997i)

HFN-SD-W314-ABU-002, Project W-314 241-AN-A Valve Pit Upgrade Acceptance for Beneficial Use (Warnick 1997a)

HFN-SD-W314-ABU-003, Project W-314 AN-B Valve Pit Upgrade Acceptance for Beneficial Use (Warnick 1997b)

HFN-SD-W314-ABU-004, Project W-314 SN-630 Transfer Line AZ-02A to AN-B Acceptance for Beneficial Use (Warnick 1997c)

HFN-SD-W314-ABU-005, Project W-314 AX-B Valve Pit Upgrade Acceptance for Beneficial Use (Warnick 1997d)

HFN-SD-W314-ABU-006, Project W-314 SN-632 Transfer Line AX-B to AZ-02A Acceptance for Beneficial Use (Warnick 1997e)

HFN-SD-W314-ABU-007, Project W-314 AZ-02A Pump Pit Upgrade Acceptance for Beneficial Use (Warnick 1997f)

HFN-SD-W314-ABU-008, Project W-314 SN-634 Transfer Line A-B to AX-B Acceptance for Beneficial Use (Warnick 1997g)

HFN-SD-W314-ABU-009, Project W-314 AB Valve Pit Upgrade Acceptance for Beneficial Use (Warnick 1997h) 


\section{Calculation/Analysis}

TBD

9. Supporting Documents

TBD

10. Authorization Basis Changes

HNF-SD-WM-BIO-001 (FDH 1999) and HNF-SD-WM-TSR-006 (LMHC 1999d), the project upgrades are being performed under the existing $A B$ via use of the USQ process

11. Reliability, Availability, Maintainability (RAM) Analysis

TBD

12. Constructability, Operability, and Implementability Analysis

TBD

13. Vendor Drawings/Instruction Manuals

TBD

14. System Design Description

TBD

15. Spare Parts List

TBD

16. Control Drawings

Listing of project drawings for this project are in the project files.

17. Safety Equipment List

HNF-SD-WM-SEL-040, TWRS Facility Safety Equipment List (Jensen 1998); project will amend the existing safety equipment list.

18. Construction Specifications

Listing of construction specifications for this project are in the project files.

19. Fabrication Specifications

Listing of fabrication specifications for this project are in the project files.

Inter-related documents (successors and predecessors)

To be developed. 
HNF-1901 Rev 1

\begin{tabular}{|l|l|}
\hline Assigned Document Number & Maintained Current? \\
\hline B.9 & Yes \\
\hline Document Name \\
Technical Baseline Documents for Project W-211 \\
\hline Responsible Organization \\
LMHC \\
\hline Status of Preparation/Revision \\
Various \\
\hline Source Information Designation \\
Technical baseline documents related to the W-211 Project, Initial Tank Retrieval System. \\
\hline Brief Summary of Content \\
The project technical baseline documents are divided into 19 categories as identified below. \\
The categories were developed in accordance with applicable engineering plans and \\
procedures. \\
1. Functional Design Criteria \\
HNF-SD-W211-FDC-001, Rev. 3, Functional Design Criteria, Project W-211, Initial Tank \\
Retrieval Systems (Rieck 1997c) \\
2. Conceptual Design Report \\
WHC-SD-W211-CDR-001, Rev. 0, Conceptual Design Report, Initial Tank Retrieval Systems \\
for Project W-211 (Rieck 1994) \\
3. Alternate Design Study. \\
TBD \\
4. Final Design Review Report \\
TBD W-211 is a phased project. Each phase will release a design report as completed. \\
\hline
\end{tabular}




\section{Acceptance Test Plan}

TBD

6. Operational Test Plan

TBD

7. Operational Readiness Review/Acceptance Beneficial Use

TBD

8. Calculation/Analysis

Analysis is needed for each phase and the reports are issued as needed

9. Supporting Documents

Documents are released as needed for each phase

10. Authorizátion Basis Changes

HNF-SD-W211-PSAD-001, Safety Assessment for Initial Tank Retrieval Systems - Project W-211 (Rieck 1998)

HNF-SD-WM-BIO-001, Tank Waste Remediation System Basis for Interim Operation (FDH 1999)

11. Reliability, Availability, Maintainability (RAM) Analysis

TBD

12. Constructability, Operability, and Implementability Analysis

Constructability is checked during drawing/design review.

13. Vendor Drawings/Instruction Manuals

TBD

14. System Design Description

TBD

15. Spare Parts List

TBD 
HNF-1901 Rev 1

16. Control Drawings

Listing of project drawings are in the W-211 project file.

17. Safety Equipment List

HNF-SD-WM-SEL-040, Rev. 1, TWRS Facility Safety Equipment List (Jensen 1998)

18. Construction Specifications

Listing of project construction specifications are found in the W-211 project files.

19. Fabrication Specifications

W211-AP24-P002, Mobile Water Heater/Boiler Package (Rieck 1997d)

W211-AP24-P003, Controlled Volume Metering Pump (Rieck 1997a)

W211-AP24-P004, Steel Storage Tanks (Rieck 1997e)

W211-AP24-P005, Diluent/Flush Pump (Rieck 1997b)

W211-P001, Procurement Specification, Slurry Transfer Pump (Rieck and McKinney 1997)

W211-P003, Retrieval Control System Enclosures (Rieck and McKinney 1996a)

W211-P005, Waste Mobilization Mixer Pump (Rieck and McKinney 1996b)

Inter-related documents (successors and predecessors)

To be developed. 
HNF-1901 Rev 1

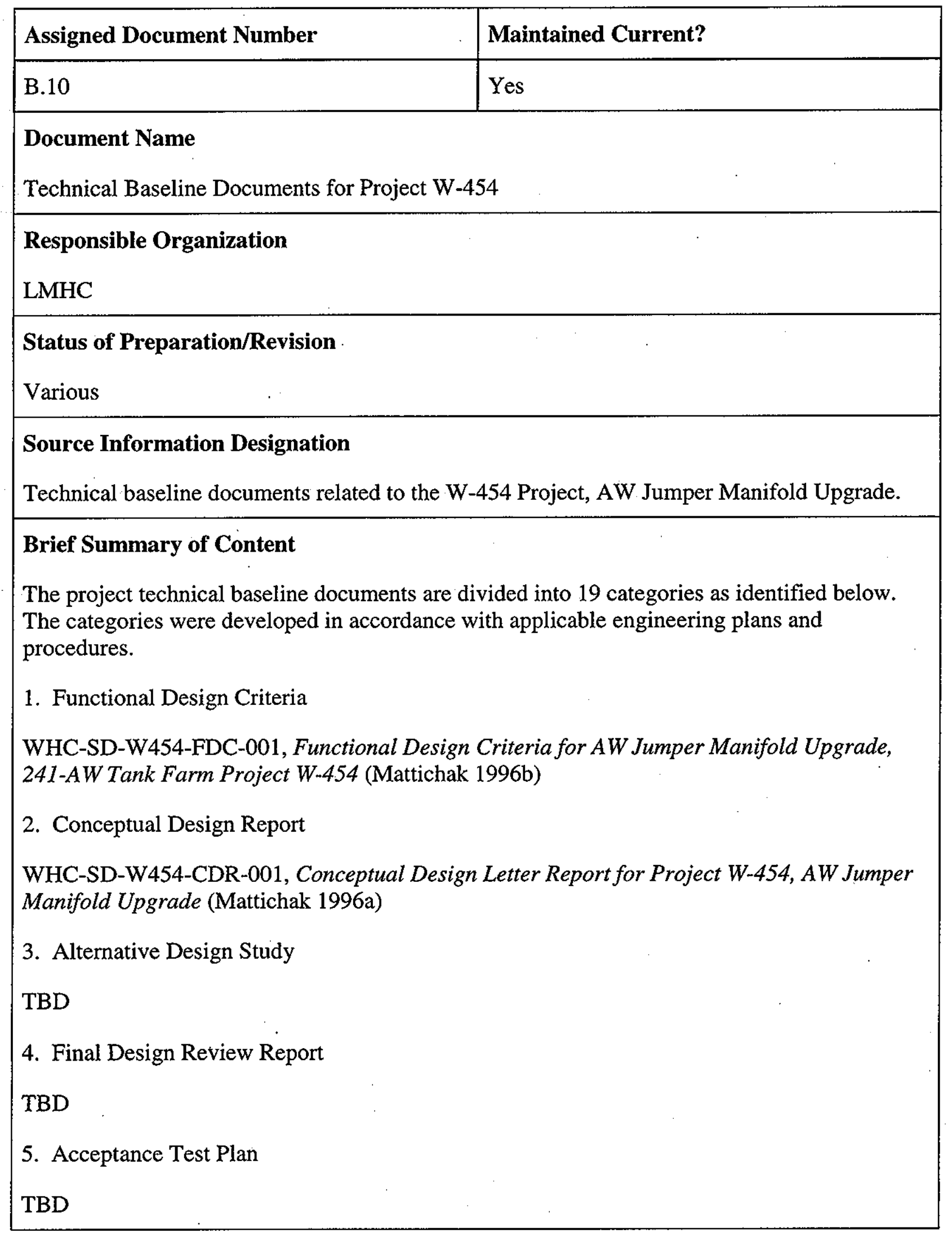


HNF-1901 Rev 1

6. Operational Test Plan

TBD

7. Operational Readiness Review/Acceptance Beneficial Use

TBD

8. Calculation/Analysis

TBD

9. Supporting Documents

TBD

10. Authorization Basis Changes

TBD

11. Reliability, Availability, Maintainability (RAM) Analysis

TBD

12. Constructability, Operability, and Implementability Analysis

TBD

13. Vendor Drawings/Instruction Manuals

TBD

14. System Design Description

TBD

15. Spare Parts List

TBD

16. Control Drawings

TBD

17. Safety Equipment List

TBD

18. Construction Specifications

TBD

19. Fabrication Specifications

TBD

Inter-related documents (successors and predecessors)

To be determined. 
HNF-1901 Rev 1

\begin{tabular}{|l|l|}
\hline Assigned Document Number & Maintained Current? \\
\hline B.11 & Yes \\
\hline Document Name \\
Technical baseline documents for Project W-058 \\
\hline Responsible Organization \\
LMHC \\
\hline Status of Preparation/Revision \\
Various \\
\hline Source Information Designation \\
Technical baseline documents related to the W-058 Project, Cross Site Transfer Line. \\
\hline Brief Summary of Content \\
The project technical baseline documents are divided into 19 categories as identified below. \\
The categories were developed in accordance with applicable engineering plans and \\
procedures. \\
1. Functional Design Criteria \\
WHC-SD-W058-FDC-001, Functional Design Criteria for Project W-058, Replacement of the \\
Cross-Site Transfer System (Brantley 1996) \\
2. Conceptual Design Report \\
WHC-SD-W058-CDR-001, Conceptual Design Report Replacement of the Cross-Site Transfer \\
(Reep 1992) \\
3. Alternate Design Study \\
Not Applicable \\
4. Final Design Review Report \\
Not Applicable \\
\hline
\end{tabular}


HNF-1901 Rev 1

5. Acceptance Test Plan

HNF-SD-W058-SUP-002, Project W-058 Startup Test Plan (Howell 1997)

6. Operational Test Plan

HNF-SD-W058-SUP-002, Project W-058 Startup Test Plan (Howell 1997)

7. Operational Readiness Review/Acceptance Beneficial Use

HNF-SD-W058-ABU-001, Acceptance for Beneficial Use, Project W-058 (Gilbert 1998)

8. Calculation/Analysis

Drawing \# H-2-822200 Drawing List, Rev. 3, Sht. 2 (1998), for list of calculations for Civil/Structural, Architectural, Mechanical, Instrumentation, and Electrical

9. Supporting Documents

TBD

10. Authorization Basis Changes

WHC-SD-W058-PSAR-001, Replacement of the Cross-Site Transfer System Preliminary Safety Analysis Report (Kidder 1996)

HNF-SD-WM-BIO-001, Rev. 0, Tank Waste Remediation System Basis for Interim Operation (FDH 1999)

11. Reliability, Availability, Maintainability (RAM) Analysis

TBD

12. Constructability, Operability, and Implementability Analysis

Constructability was checked per Drawing Review/Approval Traveler

13. Vendor Drawings/Instruction Manuals

TBD

14. System Design Description

Draft has been issued as W-058 System Design Description; final release TBD

15. Spare Parts List

TBD 
16. Control Drawings

TBD

17. Safety Equipment List

TBD

18. Construction Specifications

W058-C001, Technical Requirements Buried Pipeline for Replacement of the Cross Site Transfer Construction Specification

W058-C002, Construction Specification for Pipeline Tie-Ins for Replacement of the Cross Site Transfer System

W058-C003, Diversion Box/Vent Station

W058-C004, Sagebrush Mitigation 600 Area

W058-C005, C5 Flushing System Construction Specification

19. Fabrication Specifications

W058-P001, Procurement Specification Slurry Transfer Pump

W058-P002, Procurement Specification Process Monitor and Control System

W058-P005, Process Instruments

W058-P006, Horizontal End Suction Centrifugal Pump

W058-P008, Compressed Air System

W058-P009, Air Operated Ball Valves

W058-P010, Procurement Specification Rupture Disk/Relief Valve

W058-P011, Electric Circulation Heating System

W058-P012, Chemical Feed System

W058-P013, Calibration and Testing Laboratory Services Construction Specification for Tank AP-104 Upgrade

Inter-related documents (successors and predecessors)

To be developed. 
HNF-1901 Rev 1

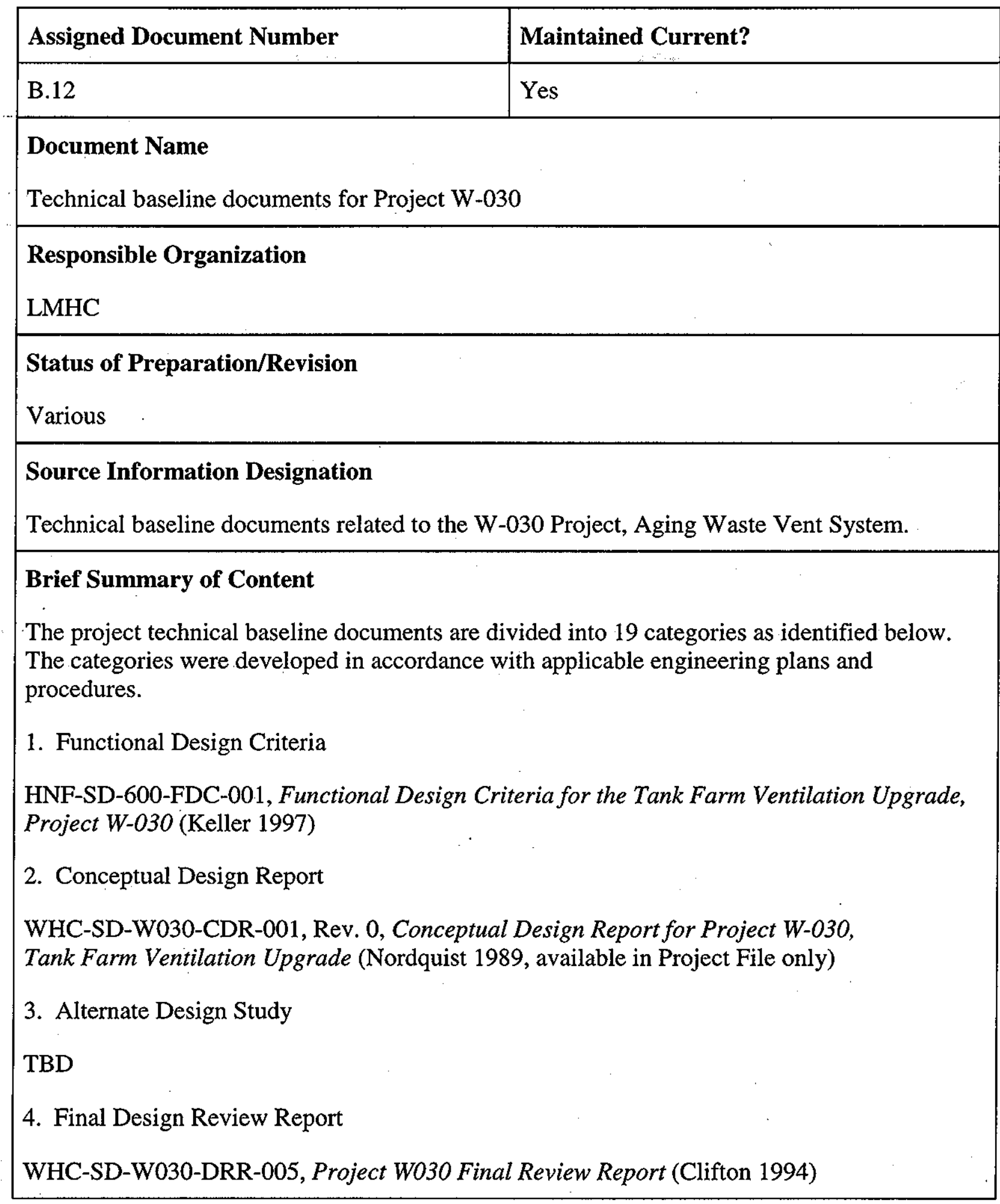


HNF-1901 Rev 1

5. Acceptance Test Plan

WHC-SD-W030-ATP-001, Acceptance Test Procedure for Cathodic Protection, Rectifier 31 (Clifton 1995b)

WHC-SD-W030-ATP-002, Acceptance Test Procedure for Cathodic Protection, Rectifier 41 (Clifton 1995c)

WHC-SD-W030-ATP-003, Acceptance Test Procedure for Cathodic Protection, Rectifier 11 (Clifton 1995a)

WHC-SD-W030-ATP-004, Acceptance Test Procedure - Tank Farm and Miscellaneous Instrumentation (Clifton 1996a)

WHC-SD-W030-ATP-006, Acceptance Test Procedure - Tank Farm Ventilation Upgrade W030; Primary Vent Filter Train (Clifton 1996b)

WHC-SD-W030-ATP-007, Acceptance Test Procedure Backup Power System (Colosi 1995)

WHC-SD-W030-ATP-0011, Acceptance Test Procedure for W030 Monitor and Control System Software (Hill 1995)

6. Operational Test Plan

TBD

7. Operational Readiness Review/Acceptance Beneficial Use

TBD

8. Calculation/Analysis

Project W-030 summary calculations, contained in the project records

9. Supporting Documents

TBD

10. PSAR and Authorization Basis

HNF-SD-WM-BIO-001 (FDH 1999), Addendum 3

11. Reliability, Availability, Maintainability (RAM) Analysis

TBD 
HNF-1901 Rev 1

12. Constructability, Operability, and Implementability Analysis

TBD

13. Vendor Drawings/Instruction Manuals

H-2-131000, Drawing List

14. System Design Description

TBD

15. Spare Parts List

HNF-1759, Spare Parts List W-030 Tank Farm Ventilation Upgrade (Castleberry 1997)

16. Control Drawings

H-2-131000, Drawing List

17. Safety Equipment List

ECN 642900, HNF-SD-WM-SEL-040 (Jensen 1998)

18. Construction Specifications

W030-C001, Divisions 2 through 16 of Construction Specification-Site Preparation for Tank Farm Ventilation Upgrade (1992)

W030-C002, Construction Specification Tank Farm Ventilation Upgrade (1994)

W030-C003, Construction Specification for Tank Farm Ventilation Upgrade (1994)

19. Fabrication Specifications

TBD

Inter-related documents (successors and predecessors)

To be developed. 
HNF-1901 Rev 1

\begin{tabular}{|c|c|}
\hline Assigned Document Number & Maintained Current? \\
\hline B.13 & Yes \\
\hline \multicolumn{2}{|c|}{$\begin{array}{l}\text { Document Name } \\
\text { Technical baseline documents resulting from Project W-320 }\end{array}$} \\
\hline \multicolumn{2}{|l|}{ Responsible Organization } \\
\hline \multicolumn{2}{|l|}{ Status of Preparation/Revision } \\
\hline \multicolumn{2}{|l|}{ Source Information Designation } \\
\hline \multicolumn{2}{|l|}{ 1. Functional Design Criteria } \\
\hline \multicolumn{2}{|c|}{$\begin{array}{l}\text { HNF-SD-W320-FDC-001, Functional Design Criteria for Tank 241-C-106 Waste Retrieval, } \\
\text { Project W-320 (Bailey 1997) }\end{array}$} \\
\hline \multicolumn{2}{|c|}{$\begin{array}{l}\text { WHC-SD-W320-TP-001, Project W-320 Tank 241-C-106 Waste Retrieval Sluicing System } \\
\text { Testing Plan (Bellomy 1995) }\end{array}$} \\
\hline \multicolumn{2}{|l|}{ 3. Calculation/Analysis } \\
\hline \multicolumn{2}{|r|}{ Master Calculation List (Bailey 1998a) } \\
\hline \multicolumn{2}{|c|}{$\begin{array}{l}\text { HNF-SD-WM-BIO-001, Tank Waste Remediation System Basis for Interim Operation, } \\
\text { Addendum 1, "Project W-320, Tank 241-C-106 Sluicing" (FDH 1999) }\end{array}$} \\
\hline \multicolumn{2}{|c|}{ 5. Reliability, Availability, Maintainability (RAM) Analysis } \\
\hline $\begin{array}{l}\mathrm{HNF}-\mathrm{SD}-\mathrm{W} 320-\mathrm{ER}-005 \text {, Severe } \\
\text { Immersible Pump System (Bevin }\end{array}$ & Qualifications and Life Expectancy of \\
\hline
\end{tabular}


6. Vendor Drawings/Instruction Manuals

7. System Design Description

HNF-SD-WM-PCP-013, Tank 241-C-106 Waste Retrieval Sluicing System Process Control Plan (Carothers et al. 1998) and HNF-SD-W320-DB-001, Design Basis Document Project W-320, Tank 241-C-106 Sluiding Project Rebaselining Change Request New Scope (NHC 1998).

8. Spare Parts List

HNF-2404, Project W-320 241-C-106 Waste Retrieval Spare Parts List (Bailey 1998b)

9. Control Drawings

H-2-818423, Rev. 1, Project W-320 Drawing Index

10. Safety Equipment List

HNF-1559, Preliminary Engineering Analysis for Safety Class and Safety Significant WRSS Equipment (Bailey and Bevins 1997)

11. Construction Specifications

W320-C001, Construction Specification-Tank 241-C-106 Sluicing

Package 1-Sitework/Interfarm Piping System

W320-C002, Construction Specification Equipment Removal System

W320-C005, Construction Specification Tank 241-C-106 Sluicing Package for C-Tank Farm

W320-C006, Tank 241-C-106 Sluicing Package 5 - Process Building Skid Fabrication

W320-C007, Construction Specification Tank 241-C-106 Sluicing Packáge 3 - AY Tank Farm

12. Fabrication Specifications

W320-P001, Exhaust Skid Ventilation Air Cleanup Trains

W320-P002, Procurement Specification Liquid Chiller Skid Mounted

W320-P003, Procurement Specification Filter High Efficiency Metal

W320-P004, Procurement Specification Heat Exchanger

W320-P005, High Efficiency Mist Eliminator

W320-P006, Procurement Specification Fan Recirculation Cooling 
HNF-1901 Rev 1

W320-P007, Electric Heating Coil

W320-P008, Procurement Specification Moisture Separator

W320-P0017, Tank 241-C-106 Sluicing

W320-P0018, Pump, Centrifugal

W320-P0020, Procurement Specification Sluicer, Hydraulic Drive and Controls Tank 241-C-106

W320-P0022, Air Compressor

W320-P0023, Air Drier

W320-P0024, Procurement Specification Winch, Slurry/Sluice Pump

W320-P0032, Procurement Specification Distribution Power Panels

W320-P0033, Electrical Equipment Skid AY-Farm

W320-P0034, Electrical Equipment Skid C-Farm

W320-P0035, Procurement Specification Seismic Shutdown System

W320-P0036, Procurement Specification Enclosure Environmental Control

W320-P0041, Isokinetic Air Sampling System

W320-P0044, Seismic Detectors

W320-P0045, Seismic Skids

Inter-related documents (successors and predecessors)

To be developed. 
HNF-1901 Rev 1

\begin{tabular}{|l|l|}
\hline Assigned Document Number & Maintained Current? \\
\hline B.14 & Yes \\
\hline Document Name \\
Technical baseline documents for Project W-151 \\
\hline Responsible Organization \\
LMHC \\
\hline Status of Preparation/Revision \\
Various \\
\hline Source Information Designation \\
Technical baseline documents related to the W-151 Project, AZ-101 Mixer Pumps. \\
\hline Brief Summary of Content \\
The project technical baseline documents are divided into 19 categories as identified below. \\
The categories were developed in accordance with applicable engineering plans and \\
procedures. \\
1. Functional Design Criteria \\
HNF-SD-W151-FDC-001, Rev. 4, Tank 101-AZ Waste Retrieval System Functional Design \\
Criteria (Nordquist 1997d) \\
2. Conceptual Design Report \\
WHC-SD-W151-CDR-001, Tank 101-AZ Waste Retrieval System Project W-151 \\
(Lambert 1990) \\
3. Alternate Design Study \\
WHC-SD-WM-ES-195, Mixer Pump Study for Project W-151 (Shaw 1992) \\
4. Final Design Review Report \\
HNF-SD-W151-DRR-002, Rev. 0, Formal Design Review Report Project W-151 Mixer Pump \\
Procurement (Crass 1997)
\end{tabular}


HNF-1901 Rev 1

5. Acceptance Test Plan

WHC-SD-W151-TS-001, Mixer Pump Test Specification Project W-151 (Nordquist 1995)

WHC-SD-W151-ATP-001, Project W-151 Flexible Receiver Radiation Detector System Acceptance Test Plan (Troyer 1995)

HNF-SD-W151-ATP-002, Cathodic Protection Acceptance Test Procedure (Nordquist 1997e)

WHC-SD-W151-TP-003, Project W-151 Test Plan (Nordquist 1996)

6. Operational Test Plan

HNF-SD-WM-PTP-027, Rev. 3, Mixer Pump Test Plan for Double-Shell Tank AZ-101

(Staehr 1999)

7. Operational Readiness Review/Acceptance Beneficial Use

HNF-SD-WM-ABU-023, Document Required for Acceptance for Beneficial Use of Project W-151, Tank 101-AZ Waste Retrieval System (Nordquist 1997a)

8. Calculation/Analysis

WHC-SD-W151-DA-003, Stress Analysis of 4- to 6-Inch and 42-Inch Flexible Receiver (Ziada 1994)

WHC-SD-W151-DA-004, W-151 Mixer Pump Energy Absorption Cylinder Analysis (Ziada 1996)

WHC-SD-W151-DA-005, 241-AZ-101 Mixer Pump Support Assembly Extension Riser, and Spray Wash System Design Verification (Moody 1996)

WHC-SD-W151-DA-006, W-151 Steam Coil Fatigue Analysis for Mixer Pump Jet Loads (Crass 1996a)

WHC-SD-W151-DA-007, W-151 Transfer Pump Stress Analysis for Mixer Pump Jet Loads (Crass 1996b)

HNF-SD-W151-DA-008, Evaluation of the Effect of Project W-151 Mixer Pump Jets on InTank Equipment Considering Potential Sludge Buildup on Equipment in Waste

Tank 241-AZ-101 (Julyk 1997)

Additional documentation to be determined. 
HNF-1901 Rev 1

9. Supporting Documents

WHC-SD-WM-ES-195, Mixer Pump Study for Project W-151 (Shaw 1992)

HNF-SD-W151-FVP-001, Project W-151 Project Field Verification Documentation

(Nordquist 1997c)

HNF-SD-W151-TRP-003, Project W-151 Checkout - Testing Report (Nordquist 1997b)

10. PSAR and Authorization Basis

WHC-SD-W151-PSAR-001, Preliminary Safety Analysis Report for Project W151, Tank 241-AZ-101 Waste Retrieval System (Bourger and Conner 1992)

HNF-SD-WM-BIO-001, Addendum 4 (FDH 1999)

HNF-SD-WM-TSR-006 (LMHC 1999)

11. Reliability, Availability, Maintainability (RAM) Analysis

TBD

12. Constructability, Operability, and Implementability Analysis

TBD

13. Vendor Drawings/Instruction Manuals

H-2-78870, TWRS Top Drawing Index (CVI \#22515)

14. System Design Description

WHC-SD-W151-SDRD-001, Project W-151 Supplemental Design Requirements

(Kohlman 1993)

15. Spare Parts List

HNF-SD-WM-ABU-023, Document Required for Acceptance for Beneficial Use of Project W-151, Tank 101-AZ Waste Retrieval System (Nordquist 1997a)

16. Control Drawings

H-2-78870, TWRS Top Drawing Index; H-2-79335, TWRS - Drawing Index 4-6" Tank 101-AZ Waste Retrieval System; H-2-79207, TWRS Drawing Index Tank AZ-101 Drywell/Profile Thermocouple; H-2-80936, Area Map Drawing List 
17. Safety Equipment List

TBD

18. Construction Specifications

W151-C001, Construction Specification 101-AZ Waste Retrieval System Cold Test Facility

W151-C002, Construction Specification Tank 101-AZ Waste Retrieval Systems

W151-C003, Construction Specification Tank 101-AZ Waste Retrieval Systems

19. Fabrication Specifications

WHC-S-0037, High Pressure Hot Waste System Project W151 Tank 101-AZ Waste Retrieval System

WHC-S-0040, Waste Mobilization Mixer Pump Project W151 Tank AZ-101 Waste Retrieval System

WHC-S-0099, Waste Tank Riser - Drywell Mapping Positioner

WHC-S-0410, Procurement Specification for the 241-AZ-101, W-151 Suspended Fixture and Weld Specification Camera System

V-W151-0002, 101-AZ Mixer Pump Variable Speed Drive

V-W151-0003, Modifications for Grove Crane at 1100

V-W151-0004, 101-AZ Sludge Mobilization Monitor Cable and Cable Reel

Inter-related documents (successors and predecessors)

To be determined. 
HNF-1901 Rev 1

\begin{tabular}{|l|l|}
\hline Assigned Document Number & Maintained Current? \\
\hline B.15 & Yes \\
\hline Document Name \\
HNF-2863, Waste Feed Delivery System Phase I Baseline RAM Assessment July 1998 \\
(Papp 1998b) \\
\hline Responsible Organization \\
LMHC \\
\hline Status of Preparation/Revision \\
Revision 0 was completed. Revision 1 is being developed during FY 1999. \\
\hline Source Information Designation \\
Reliability, availability, and maintainability risk evaluation report. \\
\hline Brief Summary of Content \\
Initially, this RAM evaluation will cover feed delivery only. This report presents the results of \\
a first pass reliability, availability, and maintainability (RAM) assessment of the Phase I River \\
Protection Project (RPP) Waste Feed Delivery System (WFDS) transfers to the Privatization \\
Contractor. It is designed to be used for operational risk assessments to support the \\
development of an operations and maintenance (O\&M) concept tailored to the unique \\
requirements of the RPP Privatization Program.
\end{tabular}


HNF-1901 Rev 1

\begin{tabular}{|l|l|}
\hline Assigned Document Number & Maintained Current? \\
\hline B.16 & Yes \\
\hline Document Name \\
DOE/RL-88-21, Hanford Facility Dangerous Waste Part A Permit Application (RL 1999) \\
\hline Responsible Organization \\
LMHC \\
\hline Status of Preparation/Revision \\
Part A was completed. \\
Source Information Designation \\
Resource Conservation and Recovery Act of 1976 (RCRA) Part A permit for the tank farms as \\
a hazardous waste treatment, storage, and/or disposal facility (Section 4.2.2.2 for DST and \\
Section 4.2.2.8 for SST). \\
\hline Brief Summary of Content \\
Defines the acceptable waste codes, total volumes, and process volumes allowed for the DSTs \\
and SSTs. \\
\hline Inter-related documents (successors and predecessors) \\
To be developed. \\
\hline
\end{tabular}


HNF-1901 Rev 1

\begin{tabular}{|c|c|}
\hline Assigned Document Number & Maintained Current? \\
\hline B. 17 & Yes \\
\hline \multicolumn{2}{|l|}{ Document Name } \\
\hline \multicolumn{2}{|c|}{ HNF-4474, RPP Environmental Permits and Related Documentation (Dexter 1999) } \\
\hline \multicolumn{2}{|l|}{ Responsible Organization } \\
\hline \multicolumn{2}{|l|}{ LMHC } \\
\hline \multicolumn{2}{|l|}{ Status of Preparation/Revision } \\
\hline \multicolumn{2}{|c|}{ Revision 1 was issued August 4, 1999.} \\
\hline \multicolumn{2}{|l|}{ Source Information Designation } \\
\hline \multicolumn{2}{|c|}{ Environmental permits and related documentation. } \\
\hline \multicolumn{2}{|l|}{ Brief Summary of Content } \\
\hline \multicolumn{2}{|c|}{$\begin{array}{l}\text { This document contains the current list of environmental permits and related documentation } \\
\text { for River Protection Project (RPP) facilities and activities. Copies of these permits and related } \\
\text { approvals are maintained by RPP Environment, Safety, Health and Quality Assurance. }\end{array}$} \\
\hline \multicolumn{2}{|c|}{ Inter-related documents (successors and predecessors) } \\
\hline To be developed. & \\
\hline
\end{tabular}


HNF-1901 Rev 1

\begin{tabular}{|l|l|}
\hline Assigned Document Number & Maintained Current? \\
\hline B.18 & No \\
\hline Document Name \\
$\begin{array}{l}\text { Correspondence No. 9761603, Radioactive Air Emissions Notice of Construction (NOC) } \\
\text { Project W-314, Tank Farm Restoration and Safe Operations (Rasmussen 1997) }\end{array}$ \\
\hline Responsible Organization \\
LMHC \\
\hline $\begin{array}{l}\text { Status of Preparation/Revision } \\
\text { Delivered to Washington State Department of Health and U.S. Environmental Protection } \\
\text { Agency, December 1997. Awaiting approval. }\end{array}$ \\
\hline $\begin{array}{l}\text { Source Information Designation } \\
\text { W-314 Project Air Permit with the U.S. Environmental Protection Agency, Washington State } \\
\text { Department of Health, and Washington State Department of Ecology. }\end{array}$ \\
\hline Brief Summary of Content \\
This document serves as a notice of construction (NOC), pursuant to the requirements of \\
Washington Administrative Code (WAC) 246-247-060, and as a request for approval to \\
construct pursuant to 40 Code of Federal Regulations (CFR) 61.96 for the activities associated \\
with Project W-314, Tank Farm Restoration and Safe Operation. \\
\hline $\begin{array}{l}\text { Inter-related documents (successors and predecessors) } \\
\text { To be developed. }\end{array}$ \\
\hline
\end{tabular}


HNF-1901 Rev 1

\begin{tabular}{|l|l|}
\hline Assigned Document Number & Maintained Current? \\
\hline B.19 & No \\
\hline
\end{tabular}

Document Name

Correspondence No. 9400852, Notice of Construction Application Pursuant to Washington Administrative Code 246-247 for Ventilation Upgrades, 241-AY and 241-AZ Tank Farms (Bauer 1994a)

Responsible Organization

LMHC

Status of Preparation/Revision

Awaiting approval.

Source Information Designation

Air Permit for 241-AY and 241-AZ Ventilation Upgrade Project (includes Projects W-151 and W-030) with the U.S. Environmental Protection Agency, Washington State Department of Health, and Washington State Department of Ecology.

\section{Brief Summary of Content}

This document is a notice of construction (NOC) for Ventilation Upgrades, 241-AY and 241-AZ Tank Farms. This NOC was submitted pursuant to Washington Administrative Code (WAC) 246-247, "Radiation Protection--Air Emissions." The NOC includes two projects: Project W-151 and Project W-030.

Inter-related documents (successors and predecessors)

To be developed. 
HNF-1901 Rev 1

\begin{tabular}{|c|c|}
\hline Assigned Document Number & Maintained Current? \\
\hline B. 20 & No \\
\hline \multicolumn{2}{|c|}{$\begin{array}{l}\text { Correspondence No. } 9400853, \text { Notice of Construction Application Pursuant to Washington } \\
\text { Administrative Code 173-460 for Ventilation Upgrades, } 241 \text {-AY and } 241 \text {-AZ Tank Farms } \\
\text { (Bauer 1994b) }\end{array}$} \\
\hline $\begin{array}{l}\text { Responsible Organization } \\
\text { LMHC }\end{array}$ & \\
\hline \multicolumn{2}{|l|}{ Status of Preparation/Revision } \\
\hline \multicolumn{2}{|c|}{$\begin{array}{l}\text { Toxic Air Permit for 241-AY and 241-AZ tank farms ventilation upgrades with the } \\
\text { U.S. Environmental Protection Agency, Washington State Department of Health, and } \\
\text { Washington State Department of Ecology. }\end{array}$} \\
\hline \multicolumn{2}{|c|}{$\begin{array}{l}\text { This document is a notice of construction (NOC) for Ventilation Upgrades, 241-AY and } \\
241-A Z \text { Tank Farms. This NOC was submitted pursuant to Washington Administrative Code } \\
\text { (WAC) } 173-460 \text {, "Controls for New Sources of Toxic Air Pollutants," as revised effective } \\
\text { February 14, 1994. The NOC includes two projects: Project W-151 and Project W-030. }\end{array}$} \\
\hline $\begin{array}{l}\text { Inter-related documents (succ } \\
\text { To be developed. }\end{array}$ & decessors) \\
\hline
\end{tabular}


HNF-1901 Rev 1

\begin{tabular}{|l|l|}
\hline Assigned Document Number & Maintained Current? \\
\hline B.21 & Yes \\
\hline
\end{tabular}

Document Name

HNF-SD-WM-BIO-001, Tank Waste Remediation System Basis for Interim Operation (FDH 1999)

Responsible Organization

LMHC

Status of Preparation/Revision

Readiness to transition from Interim Safety Basis (ISB) to Basis for Interim Operations (BIO) was approved by J. D. Wagoner, September 1997 (Wagoner 1997). Transition was implemented September 29, 1997. Revision 0 was issued in 1999.

\section{Source Information Designation}

Safety authorization basis for operation of the tank farms.

\section{Brief Summary of Content}

The BIO provides a cohesive, integrated, and systematic interim safety basis. The BIO documents the basis for the conclusion that the authorized Tank Waste Remediation System (now the River Protection Project) facility operations can be conducted safely until approval of the final safety analysis report and associated technical safety requirement document, complying with the requirements of DOE 5480.23, Nuclear Safety Analysis Reports, and DOE 5480.22, Technical Safety Requirements.

Implementation of the controls established by this BIO enhances the safe operation of RPP facilities. It also provides a sound basis for conducting effective unreviewed safety question evaluations to ensure continued safe operations.

Inter-related documents (successors and predecessors)

To be developed. 


\section{HNF-1901 Rev 1}

\begin{tabular}{|c|c|}
\hline Assigned Document Number & Maintained Current? \\
\hline B. 22 & Yes \\
\hline \multicolumn{2}{|l|}{ Document Name } \\
\hline \multicolumn{2}{|c|}{$\begin{array}{l}\text { HNF-SD-WM-TSR-006, Tank. Waste Remediation System Technical Safety Requirements } \\
\text { (LMHC 1999d) }\end{array}$} \\
\hline \multicolumn{2}{|l|}{$\begin{array}{l}\text { Responsible Organization } \\
\text { LMHC }\end{array}$} \\
\hline \multicolumn{2}{|c|}{$\begin{array}{l}\text { Status of Preparation/Revision } \\
\text { Revision 0-U was released in September } 1999 .\end{array}$} \\
\hline \multicolumn{2}{|l|}{ Source Information Designation } \\
\hline \multicolumn{2}{|c|}{$\begin{array}{l}\text { Brief Summary of Content } \\
\text { The River Protection Project (RPP) technical safety requirements (TSR) for the facilities } \\
\text { within the scope of the BIO define acceptable conditions, safe boundaries, basis thereof, and } \\
\text { management or administrative controls required to ensure safe operation during waste storage, } \\
\text { transfer, and characterization. The TSRs are based on the preventive and mitigative features } \\
\text { determined to be essential in the BIO. }\end{array}$} \\
\hline \multicolumn{2}{|c|}{ Inter-related documents (successors and predecessors) } \\
\hline
\end{tabular}


HNF-1901 Rev 1

\begin{tabular}{|l|l|}
\hline Assigned Document Number & Maintained Current? \\
\hline B.23 & Yes \\
\hline Document Name \\
HNF-SD-WM-SEL-040, TWRS Facility Safety Equipment List (Jensen 1998) \\
\hline Responsible Organization \\
LMHC \\
\hline Status of Preparation/Revision \\
Revision 1 was released in July 1998. \\
\hline Source Information Designation \\
Facility safety equipment. \\
\hline Brief Summary of Content \\
$\begin{array}{l}\text { The safety classification in this document supports the River Protection Project (RPP) facility } \\
\text { basis for interim operation (BIO). The barriers and administrative controls in the BIO to } \\
\text { prevent or mitigate the accidents analyzed are the basis for the selection of the safety } \\
\text { classification described. } \\
\text { This document provides the RPP facility with the information requirements to support the } \\
\text { occurrence reporting activities for operations and establishes the operating and maintenance } \\
\text { systems, structures, and components important to safety. }\end{array}$ \\
\hline $\begin{array}{l}\text { Inter-related documents (successors and predecessors) } \\
\text { To be developed. }\end{array}$ \\
\hline
\end{tabular}


HNF-1901 Rev 1

\section{APPENDIX C}

INFRASTRUCTURE SUPPORT DOCUMENTS

C-i 
HNF-1901 Rev 1

This page intentionally left blank.

\section{C-ii}




\begin{tabular}{|l|l|}
\hline Assigned Document Number & Maintained Current? \\
\hline C.1 & No \\
\hline Document Name \\
WHC-SD-WM-TI-750, Alternative Generation and Analysis for Phase 1 Privatization \\
Transfer System Needs (Galbraith 1996) \\
\hline Responsible Organization \\
LMHC \\
\hline Status of Preparation/Revision \\
The document was issued in September 1996. \\
\hline Source Information Designation \\
Piping system upgrades for AN, AW, and AP farms. \\
\hline Brief Summary of Content \\
This decision document provides input for Privatization Phase 1 waste staging plans for the \\
high-level waste (HLW) and low-level waste (LLW) Disposal Programs. This alternative \\
generation and analysis (AGA) report evaluates what infrastructure upgrades to existing 200 \\
East Area waste transfer systems are necessary for delivery of HLW and LLW streams to the \\
Phase 1 Private Contractor. The AGA identifies the transfer routing alternatives for \\
supernatant waste transfers from the AN, AW, and AP Tank Farms to Tanks 241-AP-102 or \\
241-AP-104. In addition, this report addresses the transfer of slurry waste from the AY and \\
AZ Tank Farms to the Phase 1 Private Contractor's facilities for HLW immobilization. \\
\hline Inter-related documents (successors and predecessors) \\
To be developed. \\
\hline
\end{tabular}




\begin{tabular}{|l|l|}
\hline Assigned Document Number & Maintained Current? \\
\hline C.2 & No \\
\hline Document Name \\
HNF-SD-WM-TI-800, Decision Document: Phase 1 Intermediate Waste Feed Staging System \\
Design Requirements (Galbraith and Daling 1997) \\
\hline Responsible Organization \\
LMHC \\
\hline Status of Preparation/Revision \\
The document was issued in October 1997. \\
\hline Source Information Designation \\
Intermediate feed staging. \\
\hline Brief Summary of Content \\
In FY 1996, a Tank Waste Remediation System Project Decision Board was convened to \\
select a strategy for preparing feed to transfer to the low-activity waste (LAW) Private \\
Contractor. The Decision Board selected a strategy referred to as "Intermediate Feed Staging." \\
In this strategy, the Hanford Site Management and Integration contractor would transfer low- \\
level waste (LLW) feed to an intermediate feed staging tank where it would be sampled to \\
validate that the material is within the Private Contractor's feed specification. Once this is \\
validated, the feed material would be transferred to the Private Contractor's feed tanks. This \\
document provides design requirements for modification to Tanks 241-AP-102 and \\
241-AP-104. \\
\hline $\begin{array}{l}\text { Inter-related documents (successors and predecessors) } \\
\text { To be developed. }\end{array}$ \\
\hline
\end{tabular}


HNF-1901 Rev 1

\begin{tabular}{|c|c|}
\hline Assigned Document Number & Maintained Current? \\
\hline C. 3 & Yes \\
\hline \multicolumn{2}{|l|}{ Document Name } \\
\hline LMHC & \\
\hline \multicolumn{2}{|l|}{ Variouis } \\
\hline \multicolumn{2}{|c|}{$\begin{array}{l}\text { Technical baseline documents related to the W-519 Project, TWRS Privatization Phase } 1 \\
\text { Infrastructure Support }\end{array}$} \\
\hline \multicolumn{2}{|c|}{$\begin{array}{l}\text { The project technical baseline documents are divided into } 19 \text { categories as identified below. } \\
\text { The categories were developed in accordance with applicable engineering plans and } \\
\text { procedures. }\end{array}$} \\
\hline \multicolumn{2}{|l|}{ 1. Functional Design Criteria } \\
\hline \multicolumn{2}{|c|}{$\begin{array}{l}\text { WHC-SD-WM-DRD-014, TWRS Phase } 1 \text { Privatization Liquid Effluent Transfer and Roads } \\
\text { Design Requirements Document (Parazin 1996b) }\end{array}$} \\
\hline \multicolumn{2}{|c|}{$\begin{array}{l}\text { WHC-SD-WM-DRD-015, Phase } 1 \text { Privatization Raw and Potable Water Design } \\
\text { Requirements Document (Parazin 1996a) }\end{array}$} \\
\hline \multicolumn{2}{|c|}{$\begin{array}{l}\text { HNF-SD-WM-DRD-013, TWRS Privatization Phase } 1 \text { Site Development Design Requirements } \\
\text { Document (Shord 1997) }\end{array}$} \\
\hline \multicolumn{2}{|c|}{$\begin{array}{l}\text { WHC-SD-WM-DRD-011, Design Requirements Document, Design Requirements for the } \\
\text { Phase } 1 \text { Privatization Facility Electrical Power (Singh 1996) }\end{array}$} \\
\hline \multicolumn{2}{|l|}{ 2. Conceptual Design Report } \\
\hline \multicolumn{2}{|c|}{$\begin{array}{l}\text { HNF-SD-W503-CDR-001, TWRS Privatization Phase 1, Electrical Power System } \\
\text { (Singh 1997e) }\end{array}$} \\
\hline $\begin{array}{l}\text { HNF-SD-W504-CDR-001, Con } \\
\text { Potable Water, Subproject W-50 }\end{array}$ & $\begin{array}{l}\text { Report TWRS Privatization Phase } 1 \text { Raw and } \\
\text { ) }\end{array}$ \\
\hline
\end{tabular}


HNF-SD-W505-CDR-001, Conceptual Design Report TWRS Privatization Phase 1 Site Development and Roads Subproject W-505 (Singh 1997c)

HNF-SD-W506-CDR-001, Conceptual Design Report TWRS Privatization Phase 1 Liquid Effluent Transfer Systems Subproject W-506 (Singh 1997a)

HNF-SD-W519-CDR-001, Summary Conceptual Design Report, TWRS Privatization Phase I Infrastructure Support, Project W-519 (Singh 1997d)

3. Alternative Design Study

TBD

4. Final Design Review Report

TBD

5. Acceptance Test Plan

TBD

6. Operational Test Plan reports

TBD

7. Operational Readiness Review/Acceptance Beneficial Use

TBD

8. Calculation/Analysis

TBD

9. Supporting Documents

WHC-SD-TWR-DSD-001, TWRS Privatization Phase 1, Master Site Plan (Parazin 1996c)

HNF-SD-TWR-EV-001, TWRS Phase 1 Privatization Site Environmental Baseline and Characterization Plan (Shade 1997)

10. PSAR and Authorization Basis

TBD 
11. Reliability, Availability, Maintainability (RAM) Analysis

TBD

12. Constructability, Operability, and Implementation

TBD

13. Vendor Drawings/Instruction Manuals

TBD

14. System Design Description

TBD

15. Spare Parts List

TBD

16. Control Drawings

TBD

17. Safety Equipment List

TBD

18. Construction Specifications

TBD

19. Fabrication Specifications

TBD

Inter-related documents (successors and predecessors)

To be developed 
HNF-1901 Rev 1

This page intentionally left blank. 
HNF-1901 Rev 1

APPENDIX D

PRIVATE CONTRACTOR

INTERFACE DOCUMENTS

D-i 
HNF-1901 Rev 1

This page intentionally left blank.

D-ii 
HNF-1901 Rev 1

\begin{tabular}{|l|l|}
\hline Assigned Document Number & Maintained Current? \\
\hline D.1 & Yes \\
\hline Document Name \\
BNFL-5193-ID-01, Interface Control Document Between DOE and BNFL Inc. for Raw Water \\
(BNFL 1998a) \\
\hline Responsible Organization \\
BNFL Inc., LMHC, and DOE \\
\hline Status of Preparation/Revision \\
Draft. Work is continuing on final. \\
\hline $\begin{array}{l}\text { Source Information Designation } \\
\text { Establishes interfaces with Private Contractor for the delivery and use of raw water. }\end{array}$ \\
\hline $\begin{array}{l}\text { Brief Summary of Content } \\
\text { This document defines the interfaces, responsibilities, and timeframes between DOE, the } \\
\text { Project Hanford Management Contract (PHMC) team, and BNFL Inc. with respect to raw } \\
\text { water during Privatization Phase } 1 \text { activities. Included is the PHMC team responsibility to } \\
\text { install raw water piping to the Private Contractor fence and the amount of raw water to be } \\
\text { delivered. }\end{array}$ \\
\hline $\begin{array}{l}\text { Inter-related documents (successors and predecessors) } \\
\text { To be developed }\end{array}$ \\
\hline
\end{tabular}


HNF-1901 Rev 1

\begin{tabular}{|c|c|}
\hline Assigned Document Number & Maintained Current? \\
\hline D.2 & Yes \\
\hline \multicolumn{2}{|l|}{ Document Name } \\
\hline \multicolumn{2}{|c|}{$\begin{array}{l}\text { BNFL-5193-ID-02, Interface Control Document Between DOE and BNFL Inc. for Potable } \\
\text { Water (BNFL 1998b) }\end{array}$} \\
\hline \multicolumn{2}{|l|}{ Responsible Organization } \\
\hline \multicolumn{2}{|l|}{ BNFL Inc., LMHC, and DOE } \\
\hline \multicolumn{2}{|l|}{ Status of Preparation/Revision } \\
\hline \multicolumn{2}{|c|}{ Draft. Work is continuing on final. } \\
\hline \multicolumn{2}{|l|}{ Source Information Designation } \\
\hline \multicolumn{2}{|c|}{ Establishes interfaces with Private Contractor for the delivery and use of potable water. } \\
\hline \multicolumn{2}{|l|}{ Brief Summary of Content } \\
\hline \multirow{3}{*}{\multicolumn{2}{|c|}{$\begin{array}{l}\text { This document defines the interfaces, responsibilities, and timeframes between DOE, the } \\
\text { PHMC team, and BNFL Inc. with respect to potable water during Privatization Phase } 1 \\
\text { activities. Included is the PHMC team responsibility to install potable water piping to the } \\
\text { Private Contractor fence and the amount of potable water to be delivered. }\end{array}$}} \\
\hline & \\
\hline & \\
\hline \multicolumn{2}{|c|}{ Inter-related documents (successors and predecessors) } \\
\hline To be developed. & \\
\hline
\end{tabular}


HNF-1901 Rev 1

\begin{tabular}{|c|c|}
\hline Assigned Document Number & Maintained Current? \\
\hline D.3 & Yes \\
\hline \multicolumn{2}{|c|}{$\begin{array}{l}\text { Document Name } \\
\text { BNFL-5193-ID-03, Interface Control Document Between DOE and BNFL Inc. for } \\
\text { Radioactive Solid Waste (BNFL 1998c) }\end{array}$} \\
\hline \multicolumn{2}{|l|}{$\begin{array}{l}\text { Responsible Organization } \\
\text { BNFL Inc., LMHC, and DOE }\end{array}$} \\
\hline \multicolumn{2}{|l|}{$\begin{array}{l}\text { Status of Preparation/Revision } \\
\text { Draft. Work is continuing on final. }\end{array}$} \\
\hline \multicolumn{2}{|c|}{$\begin{array}{l}\text { Establishes interfaces with Private Contractor for the handling and managing of radioactive } \\
\text { solid waste. }\end{array}$} \\
\hline \multicolumn{2}{|c|}{$\begin{array}{l}\text { This document defines the interfaces, responsibilities, and timeframes between DOE, the } \\
\text { PHMC team, and the Private Contractor with respect to radioactive solid waste during } \\
\text { Privatization Phase } 1 \text { activities. Included is the estimation of radioactive solid volumes and } \\
\text { compliance with HNF-EP-0063, Hanford Site Solid Waste Acceptance Criteria (WMH 1998) }\end{array}$} \\
\hline \multicolumn{2}{|c|}{ Inter-related documents (successors and predecessors) } \\
\hline
\end{tabular}


HNF-1901 Rev 1

\begin{tabular}{|c|c|}
\hline Assigned Document Number & Maintained Current? \\
\hline D.4 & Yes \\
\hline \multicolumn{2}{|l|}{ Document Name } \\
\hline \multicolumn{2}{|c|}{$\begin{array}{l}\text { BNFL-5193-ID-05, Interface Control Document Between DOE and BNFL Inc. for } \\
\text { Non-Radioactive, Non-Dangerous Liquid Effluents (BNFL 1998d) }\end{array}$} \\
\hline \multicolumn{2}{|l|}{ Responsible Organization } \\
\hline \multicolumn{2}{|l|}{ BNFL Inc., LMHC, and DOE } \\
\hline \multicolumn{2}{|l|}{ Status of Preparation/Revision } \\
\hline \multicolumn{2}{|l|}{ Draft. Work is continuing on final. } \\
\hline \multicolumn{2}{|l|}{ Source Information Designation } \\
\hline \multicolumn{2}{|c|}{$\begin{array}{l}\text { Establishes interfaces with Private Contractor for the handling and managing of } \\
\text { nonradioactive, nondangerous liquid effluents. }\end{array}$} \\
\hline \multicolumn{2}{|l|}{ Brief Summary of Content } \\
\hline \multicolumn{2}{|c|}{$\begin{array}{l}\text { This document defines the interfaces, responsibilities, and timeframes between DOE, the } \\
\text { PHMC team, and the Private Contractor with respect to nonradioactive, nondangerous liquid } \\
\text { effluents during Privatization Phase } 1 \text { activities. Included are the acceptance volume and flow } \\
\text { rates from BNFL Inc., the installation and maintenance of a receiving pipeline, and regulator } \\
\text { permit requirements. }\end{array}$} \\
\hline \multicolumn{2}{|c|}{ Inter-related documents (successors and predecessors) } \\
\hline
\end{tabular}


HNF-1901 Rev 1

\begin{tabular}{|c|c|}
\hline Assigned Document Number & Maintained Current? \\
\hline D.5 & Yes \\
\hline \multicolumn{2}{|c|}{$\begin{array}{l}\text { Document Name } \\
\text { BNFL-5193-ID-06, Interface Control Document Between DOE and BNFL Inc. for } \\
\text { Radioactive, Dangerous Liquid Effluents (BNFL 1998e) }\end{array}$} \\
\hline \multicolumn{2}{|l|}{$\begin{array}{l}\text { Responsible Organization } \\
\text { BNFL Inc., LMHC, and DOE }\end{array}$} \\
\hline \multicolumn{2}{|c|}{$\begin{array}{l}\text { Status of Preparation/Revision } \\
\text { Draft. Work is continuing on final. }\end{array}$} \\
\hline \multicolumn{2}{|c|}{$\begin{array}{l}\text { Source Information Designation } \\
\text { Establishes interfaces with Private Contractor for the handling and managing of radioactive, } \\
\text { dangerous liquid effluents. }\end{array}$} \\
\hline \multicolumn{2}{|c|}{$\begin{array}{l}\text { This document defines the interfaces, responsibilities, and timeframes between DOE, the } \\
\text { PHMC team, and BNFL Inc. with respect to handling and managing radioactive, dangerous } \\
\text { liquid effluents during Privatization Phase } 1 \text { activities. Included are the acceptance volume } \\
\text { and flow rates from the Private Contractor, the installation and maintenance of a receiving } \\
\text { pipeline, and regulator permit requirements. }\end{array}$} \\
\hline Inter-related documents (successors and predecessors) & decessors) \\
\hline
\end{tabular}


HNF-1901 Rev 1

\begin{tabular}{|l|l|}
\hline Assigned Document Number & Maintained Current? \\
\hline D.6 & Yes \\
\hline
\end{tabular}

Document Name

BNFL-5193-D-09, Interface Control Document Between DOE and BNFL Inc. for Land for Siting (BNFL 1998f)

Responsible Organization

BNFL Inc., LMHC, and DOE

Status of Preparation/Revision

Draft. Work is continuing on final.

Source Information Designation

Establishes interfaces with Private Contractor for land for siting Privatization Phase 1.

\section{Brief Summary of Content}

This document defines the interfaces, responsibilities, and timeframes between DOE, the PHMC team, and BNFL Inc. with respect to land for siting Privatization Phase 1 activities. Included is the land location and size and a no-cost lease.

Inter-related documents (successors and predecessors)

To be developed. 
HNF-1901 Rev 1

\begin{tabular}{|c|c|}
\hline Assigned Document Number & Maintained Current? \\
\hline D.7 & Yes \\
\hline \multicolumn{2}{|c|}{$\begin{array}{l}\text { BNFL-5193-ID-10, Interface Control Document Between DOE and BNFL Inc. for Deactivated } \\
\text { Facility and Site (BNFL 1998g) }\end{array}$} \\
\hline \multicolumn{2}{|l|}{ Responsible Organization } \\
\hline \multicolumn{2}{|l|}{ Status of Preparation/Revision } \\
\hline \multicolumn{2}{|c|}{$\begin{array}{l}\text { Establishes interfaces with Private Contractor for facility deactivation and site turnover to DOE } \\
\text { following completion of Privatization Phase } 1 \text { activities. }\end{array}$} \\
\hline \multicolumn{2}{|c|}{$\begin{array}{l}\text { This document defines the interfaces, responsibilities, and timeframes between DOE, the PHMC } \\
\text { team, and BNFL Inc. with respect to facility deactivation and site turnover to DOE following } \\
\text { completion of Privatization Phase } 1 \text { activities. }\end{array}$} \\
\hline Inter-related documents (successors and predecessors) & ecessors) \\
\hline
\end{tabular}


HNF-1901 Rev 1

\begin{tabular}{|l|l|}
\hline Assigned Document Number & Maintained Current? \\
\hline D.8 & Yes \\
\hline Document Name \\
BNFL-5193-ID-11, Interface Control Document Between DOE and BNFL Inc. for Electricity \\
(BNFL 1998h) \\
\hline Responsible Organization \\
BNFL Inc., LMHC, and DOE \\
\hline Status of Preparation/Revision \\
Draft. Work is continuing on final. \\
\hline \begin{tabular}{l} 
Source Information Designation \\
Establishes interfaces with Private Contractor with respect to electricity delivery to Private \\
Contractor facilities during Privatization Phase 1 activities. \\
\hline Brief Summary of Content \\
This document defines the interfaces, responsibilities, and timeframes between DOE, the PHMC \\
team, and BNFL Inc. with respect to electricity delivery during Privatization Phase 1. Included \\
is the defined power supply and capacity. DynCorp Tri-Cities Services, Incorporated, will supply \\
the power.
\end{tabular} \\
\hline $\begin{array}{l}\text { Inter-related documents (successors and predecessors) } \\
\text { To be developed. }\end{array}$ \\
\hline
\end{tabular}


HNF-1901 Rev 1

\begin{tabular}{|l|l|}
\hline Assigned Document Number & Maintained Current? \\
\hline D. 9 & Yes \\
\hline
\end{tabular}

\section{Document Name}

BNFL-5193-DD-12, Interface Control Document Between DOE and BNFL Inc. for Roads and Rails (BNFL 1998i)

\section{Responsible Organization}

BNFL Inc., LMHC, and DOE

\section{Status of Preparation/Revision}

Draft. Work is continuing on final.

\section{Source Information Designation}

Establishes interfaces with Private Contractor for road use during Privatization Phase 1 activities and establishes that there will be no direct rail.

\section{Brief Summary of Content}

This document defines the interfaces, responsibilities, and timeframes between DOE, the PHMC team, and BNFL Inc. with respect to road and rail construction and use during Privatization Phase 1 activities. Included is the government responsibility to supply roads to the boundary and that the Private Contractor will build and maintain roads within the boundary. No direct rail line will be provided.

\section{Inter-related documents (successors and predecessors)}

To be developed. 
HNF-1901 Rev 1

\begin{tabular}{|l|l|}
\hline Assigned Document Number & Maintained Current? \\
\hline D.11 & Yes \\
\hline Document Name \\
$\begin{array}{l}\text { BNFL-5193-ID-14, Interface Control Document Between DOE and BNFL Inc. for Immobilized } \\
\text { High-Level Waste Product (BNFL 1998j) }\end{array}$ \\
\hline Responsible Organization \\
LMHC \\
\hline Status of Preparation/Revision \\
Draft. Work is continuing on final. \\
\hline Source Information Designation \\
$\begin{array}{l}\text { Establishes interfaces with Private Contractor for the acceptance and delivery of immobilized } \\
\text { high-level waste product by and to DOE and the PHMC team during Privatization Phase 1 } \\
\text { activities. }\end{array}$ \\
\hline Brief Summary of Content \\
This document defines the interfaces, responsibilities, and timeframes between DOE, the PHMC \\
team, and BNFL Inc. with respect to the acceptance and delivery of the immobilized high-level \\
waste product by and to DOE and the PHMC team during Privatization Phase 1 activities. \\
Included are packaging and acceptance criteria and notification requirements. \\
\hline $\begin{array}{l}\text { Inter-related documents (successors and predecessors) } \\
\text { To be developed. }\end{array}$ \\
\hline
\end{tabular}


HNF-1901 Rev 1

\begin{tabular}{|l|l|}
\hline Assigned Document Number & Maintained Current? \\
\hline D.12 & Yes \\
\hline Document Name \\
$\begin{array}{l}\text { BNFL-5193-ID-15, Interface Control Document Between DOE and BNFL Inc. for Immobilized } \\
\text { Low-Activity Waste Product (BNFL 1998k) }\end{array}$ \\
\hline Responsible Organization \\
BNFL Inc., LMHC, and DOE \\
\hline \begin{tabular}{l} 
Status of Preparation/Revision \\
Draft. Work is continuing on final. \\
\hline Source Information Designation \\
Establishes interfaces with Private Contractor for acceptance and delivery of the immobilized \\
low-activity waste product by and to DOE and the PHMC team during Privatization Phase 1 \\
activities. \\
\hline Brief Summary of Content \\
This document defines the interfaces, responsibilities, and timeframes between DOE, the PHMC \\
team, and BNFL Inc. with respect to acceptance and delivery of immobilized low-activity waste \\
product by and to DOE and the PHMC team during Privatization Phase 1 activities. Included are \\
packaging and acceptance criteria and notification requirements.
\end{tabular} \\
\hline $\begin{array}{l}\text { Inter-related documents (successors and predecessors) } \\
\text { To be developed. }\end{array}$ \\
\hline
\end{tabular}


HNF-1901 Rev 1

\begin{tabular}{|l|l|}
\hline Assigned Document Number & Maintained Current? \\
\hline D.13 & Yes \\
\hline Document Name \\
BNFL-5193-ID-16, Interface Control Document Between DOE and BNFL Inc. for Entrained \\
Solids (BNFL 19981) \\
\hline Responsible Organization \\
BNFL Inc., LMHC, and DOE \\
\hline Status of Preparation/Revision \\
Draft. Work is continuing on final. \\
\hline $\begin{array}{l}\text { Source Information Designation } \\
\text { Establishes interfaces with Private Contractor for the return of entrained solids to DOE and the } \\
\text { PHMC team from the Private Contractor during Privatization Phase 1 activities. }\end{array}$ \\
\hline $\begin{array}{l}\text { Brief Summary of Content } \\
\text { This document defines the interfaces, responsibilities, and timeframes between DOE, the PHMC } \\
\text { team, and BNFL Inc. with respect to the return of entrained solids to DOE and the PHMC team } \\
\text { from the Private Contractor during Privatization Phase 1 activities. Included is transfer- } \\
\text { mechanism (pipeline) information and lag-storage requirements. }\end{array}$ \\
\hline $\begin{array}{l}\text { Inter-related documents (successors and predecessors) } \\
\text { To be developed. }\end{array}$ \\
\hline
\end{tabular}


HNF-1901 Rev 1

\begin{tabular}{|c|c|}
\hline Assigned Document Number & Maintained Current? \\
\hline D.16 & Yes \\
\hline \multicolumn{2}{|c|}{$\begin{array}{l}\text { BNFL-5193-ID-19; Interface Control Document Between DOE and BNFL Inc. for Low-Activity } \\
\text { Waste Feed (BNFL 1998m) }\end{array}$} \\
\hline \multicolumn{2}{|l|}{ Responsible Organization } \\
\hline \multicolumn{2}{|l|}{$\begin{array}{l}\text { Status of Preparation/Revision } \\
\text { Draft. Work is continuing on final. }\end{array}$} \\
\hline \multicolumn{2}{|l|}{ Source Information Designation } \\
\hline \multicolumn{2}{|c|}{$\begin{array}{l}\text { This document defines the interfaces, responsibilities, and timeframes between DOE, the PHMC } \\
\text { team, and BNFL Inc, with respect to the delivery of low-activity waste feed to the Private } \\
\text { Contractor during Privatization Phase } 1 \text { activities. Included is the selection of waste envelopes } \\
\text { and waste quantity, provision of waste feed composition, and provision of samples to the Private } \\
\text { Contractor for testing. }\end{array}$} \\
\hline $\begin{array}{l}\text { Inter-related documents (succes } \\
\text { To be developed. }\end{array}$ & cessors) \\
\hline
\end{tabular}


HNF-1901 Rev 1

\begin{tabular}{|c|c|}
\hline Assigned Document Number & Maintained Current? \\
\hline D. 17 & Yes \\
\hline \multicolumn{2}{|c|}{$\begin{array}{l}\text { Document Name } \\
\text { BNFL-5193-ID-20, Interface Control Document Between DOE and BNFL Inc. for High-Level } \\
\text { Waste Feed (BNFL 1998n) }\end{array}$} \\
\hline \multicolumn{2}{|l|}{$\begin{array}{l}\text { Responsible Organization } \\
\text { BNFL Inc., LMHC, and DOE }\end{array}$} \\
\hline \multicolumn{2}{|c|}{$\begin{array}{l}\text { Status of Preparation/Revision } \\
\text { Draft. Work is continuing on final. }\end{array}$} \\
\hline \multicolumn{2}{|c|}{$\begin{array}{l}\text { Source Information Designation } \\
\text { Establishes interfaces with Private Contractor for the delivery of high-activity waste feed. }\end{array}$} \\
\hline \multicolumn{2}{|c|}{$\begin{array}{l}\text { Brief Summary of Content } \\
\text { This document defines the interfaces, responsibilities, and timeframes between DOE, the } \\
\text { PHMC team, and BNFL Inc. with respect to the delivery of high-level waste feed to the } \\
\text { Private Contractor during Privatization Phase } 1 \text { activities. Included is the transfer of HLW } \\
\text { feed consistent with specifications, and provision of samples to the Private Contractor for } \\
\text { testing. }\end{array}$} \\
\hline \multicolumn{2}{|c|}{ Inter-related documents (successors and predecessors) } \\
\hline
\end{tabular}


HNF-1901 Rev 1

\begin{tabular}{|c|c|}
\hline Assigned Document Number & Maintained Current? \\
\hline D.19 & Yes \\
\hline \multicolumn{2}{|c|}{$\begin{array}{l}\text { Document Name } \\
\text { BNFL-5193-ID-22, Interface Control Document Between DOE and BNFL Inc. for Air } \\
\text { Emissions (BNFL 19980) }\end{array}$} \\
\hline \multicolumn{2}{|l|}{ Responsible Organization } \\
\hline Draft. Work is continuing on final. & Status of Preparation/Revision \\
\hline \multicolumn{2}{|c|}{$\begin{array}{l}\text { Establishes interfaces with Private Contractor with respect to air emissions from the Private } \\
\text { Contractor's facilities. }\end{array}$} \\
\hline \multicolumn{2}{|c|}{$\begin{array}{l}\text { Brief Summary of Content } \\
\text { This document defines the interfaces and responsibilities for air emissions regulatory and } \\
\text { reporting requirements. DOE and PHMC team responsibilities include reviewing and } \\
\text { concurring with notices of construction, seeking modifications to the Hanford Air Operating } \\
\text { Permit, allocating emissions, and using the existing monitoring network to collect required air } \\
\text { samples. }\end{array}$} \\
\hline $\begin{array}{l}\text { Inter-related documents (succe } \\
\text { To be developed. }\end{array}$ & decessors) \\
\hline
\end{tabular}


HNF-1901 Rev 1

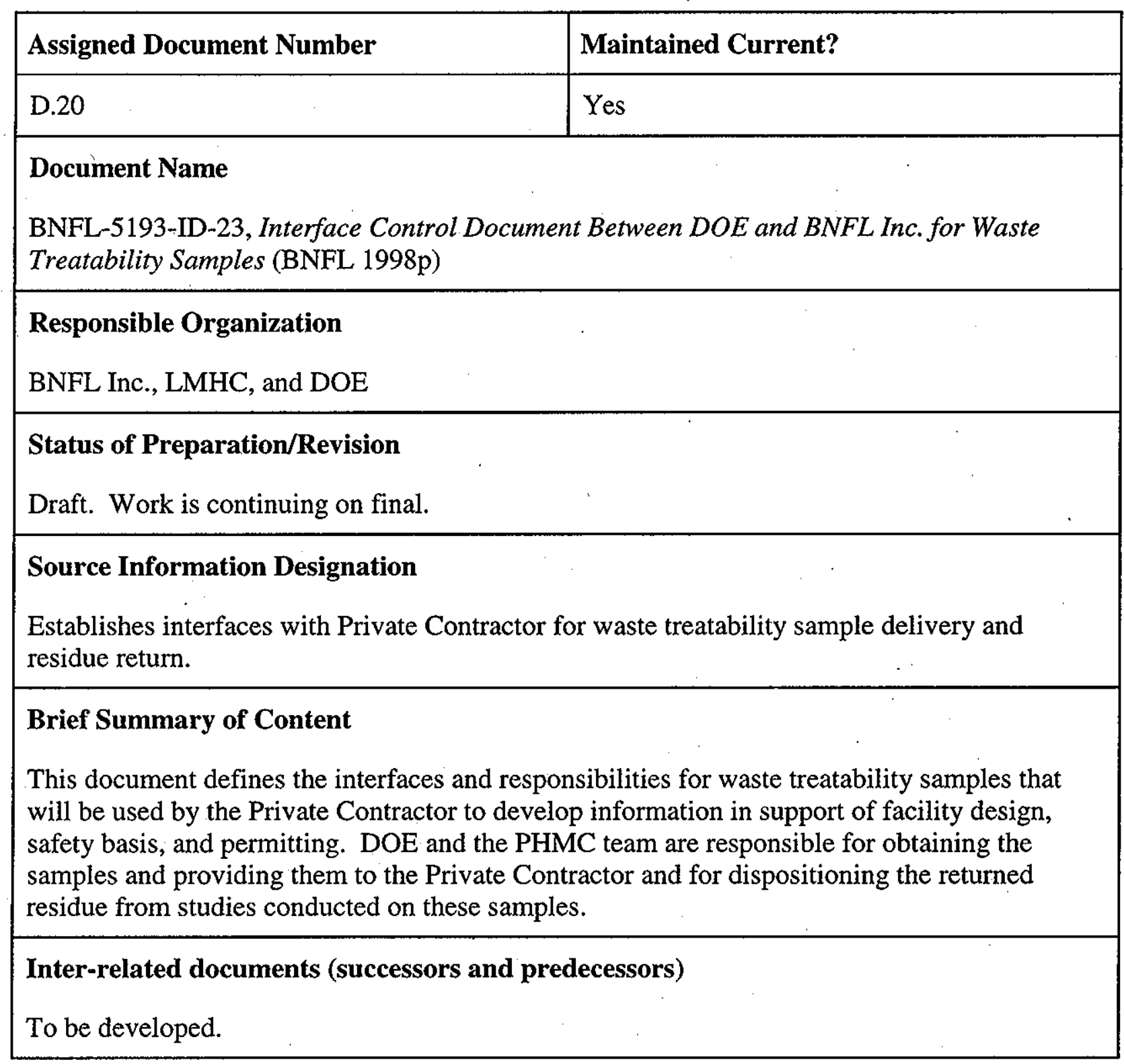


HNF-1901 Rev 1

\begin{tabular}{|c|c|}
\hline Assigned Document Number & Maintained Current? \\
\hline D. 21 & Yes \\
\hline \multicolumn{2}{|l|}{ Document Name } \\
\hline \multicolumn{2}{|c|}{$\begin{array}{l}\text { BNFL-5193-ID-25, Interface Control Document Between DOE and BNFL Inc. for Emergency } \\
\text { Response (BNFL 1998q) }\end{array}$} \\
\hline \multicolumn{2}{|l|}{ Responsible Organization } \\
\hline \multicolumn{2}{|l|}{ BNFL Inc., LMHC, and DOE } \\
\hline \multicolumn{2}{|l|}{ Status of Preparation/Revision } \\
\hline \multicolumn{2}{|c|}{ Draft. Work is continuing on final. } \\
\hline \multicolumn{2}{|l|}{ Source Information Designation } \\
\hline \multicolumn{2}{|c|}{$\begin{array}{l}\text { Establishes interfaces with Private Contractor for emergency response to events involving the } \\
\text { Private Contractor facilities and the Hanford Site. }\end{array}$} \\
\hline \multicolumn{2}{|l|}{ Brief Summary of Content } \\
\hline \multicolumn{2}{|c|}{$\begin{array}{l}\text { This document defines the interfaces and responsibilities for emergency planning notification, } \\
\text { preparedness, response, and reporting. The interface covers organization, authorities, and } \\
\text { responsibilities for BNFL Inc. and DOE. }\end{array}$} \\
\hline \multicolumn{2}{|c|}{ Inter-related documents (successors and predecessors) } \\
\hline To be developed. & \\
\hline
\end{tabular}


HNF-1901 Rev 1

\begin{tabular}{|c|c|}
\hline Assigned Document Number & Maintained Current? \\
\hline D.22 & Yes \\
\hline \multicolumn{2}{|l|}{ Document Name } \\
\hline \multicolumn{2}{|c|}{$\begin{array}{l}\text { BNFL-5193-ID-26, Interface Control Document Between DOE and BNFL Inc. for Permits } \\
\text { (BNFL 1998r) }\end{array}$} \\
\hline \multicolumn{2}{|l|}{ Responsible Organization } \\
\hline \multicolumn{2}{|l|}{ BNFL Inc., LMHC, and DOE } \\
\hline \multicolumn{2}{|l|}{ Status of Preparation/Revision } \\
\hline \multicolumn{2}{|c|}{ Draft. Work is continuing on final. } \\
\hline \multicolumn{2}{|l|}{ Source Information Designation } \\
\hline \multicolumn{2}{|c|}{ Establishes interfaces with Private Contractor for permits. } \\
\hline \multicolumn{2}{|l|}{ Brief Summary of Content } \\
\hline \multicolumn{2}{|c|}{$\begin{array}{l}\text { This document defines the interfaces with BNFL Inc. for administrative requirements for } \\
\text { permitting and compliance. DOE and the PHMC team have the responsibility to review and } \\
\text { comment on treatment-facility permit applications and provide Site information for use in } \\
\text { permit applications, permit modifications, and requested modifications to Hanford Site permits } \\
\text { to incorporate Private Contractor activities. }\end{array}$} \\
\hline \multicolumn{2}{|c|}{ Inter-related documents (successors and predecessors) } \\
\hline To be developed. & \\
\hline
\end{tabular}


HNF-1901 Rev 1

APPENDIX E

PRODUCT STORAGE AND DISPOSAL DOCUMENTS

$\mathrm{E}-\mathrm{i}$ 


\section{HNF-1901 Rev 1}

This page intentionally left blank.

\section{E-ii}


HNF-1901 Rev 1

\begin{tabular}{|c|c|}
\hline Assigned Document Number & Maintained Current? \\
\hline E.1 & No \\
\hline $\begin{array}{l}\text { Document Name } \\
\text { Approval of Critical Decisions for Phase } 1 \text { Immobilized H } \\
\text { Interim Storage and Tank Farm Restoration and Safe Oper } \\
\text { W-465, and W-314) (Alm 1996) }\end{array}$ & $\begin{array}{l}\text { Low-Activity Waste } \\
\text { (Projects W-464, }\end{array}$ \\
\hline $\begin{array}{l}\text { Responsible Organization } \\
\text { DOE-RL }\end{array}$ & \\
\hline $\begin{array}{l}\text { Status of Preparation/Revision } \\
\text { The DOE memo was issued December 26, } 1996 .\end{array}$ & \\
\hline $\begin{array}{l}\text { Source Information Designation } \\
\text { Identification of immobilized wastes to be stored. }\end{array}$ & \\
\hline $\begin{array}{l}\text { Brief Summary of Content } \\
\text { DOE decision document authorizing start of conceptual de } \\
\text { storage. }\end{array}$ & and LLW interim \\
\hline $\begin{array}{l}\text { Inter-related documents (successors and predecessors) } \\
\text { None. }\end{array}$ & \\
\hline
\end{tabular}


HNF-1901 Rev 1

\begin{tabular}{|l|l|}
\hline Assigned Document Number & Maintained Current? \\
\hline E.2 & Yes \\
\hline
\end{tabular}

Document Name

HNF-1517, Rev. 1, River Protection Project Immobilized Low-Activity Waste Disposal Plan (Burbank 1999)

Responsible Organization

LMHC

Status of Preparation/Revision

Revision 1 was completed in September 1999.

Source Information Designation

Defines baseline program planning elements for immobilized LAW design, construction, and operation.

\section{Brief Summary of Content}

This document provides a waste-stream project plan specific to the Immobilized Low-Activity Waste (ILAW) Storage and Disposal Subproject for the Washington State Department of Ecology that meets the requirements of Hanford Federal Facility Agreement and Consent Order (TriParty Agreement) Milestone M-90-01 and is consistent with the project-plan content guidelines found in Section 11.5 of the Tri-Party Agreement action plan. The plan also provides an upper tier document that can be used as the basis for future subproject line-item constructionmanagement plans.

Inter-related documents (successors and predecessors)

WHC-SD-W465-AGA-001, Alternatives Generation and Analysis Report for Immobilized LowLevel Interim Storage Architecture (Burbank 1996). 
HNF-1901 Rev 1

\begin{tabular}{|l|l|}
\hline Assigned Document Number & Maintained Current? \\
\hline E.3 & Yes \\
\hline
\end{tabular}

Document Name

HNF-1751, Rev. 1, River Protection Project Immobilized High-Level Waste Interim Storage Plan (Calmus 1999b)

Responsible Organization

LMHC

Status of Preparation/Revision

Revision 1 was completed in August 1999.

Source Information Designation

Defines baseline program planning elements for immobilized HLW design, construction, and operation.

\section{Brief Summary of Content}

This document provides a plan specific to the Hanford Tank Waste Remediation System (TWRS) Immobilized High-Level Waste (IHLW) Storage Subproject for the Washington State Department of Ecology that meets the requirements of Hanford Federal Facility Agreement and Consent Order (Tri-Party Agreement) Milestone M-90-01 and is consistent with the project plan content guidelines found in Section 11.5 of the Tri-Party Agreement action plan. The plan also provides an upper tier document that can be used as the basis for future subproject line-item construction-management plans.

Inter-related documents (successors and predecessors)

HNF-3899, Immobilized High-Level Waste Interim Storage Alternatives Generation and Analysis Decision Report (Calmus 1999a). 
HNF-1901 Rev 1

\begin{tabular}{|l|l|}
\hline Assigned Document Number & Maintained Current? \\
\hline E.4 & No \\
\hline
\end{tabular}

Document Name

Revised Interim Policy on Regulatory Structure for Low-Level Radioactive Waste Management and Disposal (Guimond and O'Toole 1996)

Responsible Organization

DOE-RL

Status of Preparation/Revision

Issued via DOE-RL letter \#96-SWT-247, August 23, 1996 (Teynor 1996).

Source Information Designation

Establishes request for U.S. Nuclear Regulatory Commission concurrence that immobilized lowactivity waste can be disposed of as "incidental waste."

\section{Brief Summary of Content}

This document sets forth the DOE revised interim policy on management, direction, and oversight of its low-level radioactive waste (LLW) disposal activities. It also sets forth a new policy for the inclusion of interacting source terms in the assessments of LLW disposal-facility performance. The policy prescribes a management, direction, and oversight approach that is compatible with the existing Departmental organization structure and (1) distinguishes functions and responsibilities among field and headquarters organizations, (2) formalizes processes for management, direction, and oversight of LLW disposal activities, emphasizing processes for review and approval of LLW disposal-facility performance assessments and maintenance of LLW disposal-facility performance assessments and composite analyses, and (3) addresses enforcement mechanisms.

Inter-related documents (successors and predecessors)

None. 
HNF-1901 Rev 1

\begin{tabular}{|c|c|}
\hline Assigned Document Number & Maintained Current? \\
\hline E.5 & No \\
\hline \multicolumn{2}{|c|}{$\begin{array}{l}\text { Document Name } \\
\text { WHC-SD-W465-AGA-001, Alternatives Generation and Analysis Report for Immobilized } \\
\text { Low-Level Waste Interim Storage Architecture (Burbank 1996) }\end{array}$} \\
\hline \multicolumn{2}{|l|}{$\begin{array}{l}\text { Responsible Organization } \\
\text { LMHC }\end{array}$} \\
\hline \multicolumn{2}{|l|}{$\begin{array}{l}\text { Status of Preparation/Revision } \\
\text { Revision } 0 \text { was issued in September } 1996 .\end{array}$} \\
\hline \multicolumn{2}{|l|}{$\begin{array}{l}\text { Source Information Designation } \\
\text { Establishes disposal options and facilities for immobilized LAW. }\end{array}$} \\
\hline \multicolumn{2}{|c|}{$\begin{array}{l}\text { The Immobilized Low-Level Waste (ILLW) Interim Storage Subproject will provide storage } \\
\text { capacity for immobilized low-level waste products sold to DOE by the Privatization Contractor. } \\
\text { This report describes alternative ILLW storage-system architectures, evaluation criteria, and } \\
\text { evaluation results to support the ILLW storage system architecture-selection decision process. }\end{array}$} \\
\hline $\begin{array}{l}\text { Inter-related documents (successors and predecessors) } \\
\text { HNF-4003, Reanalysis of Alternatives for Immobilized Low-Activi } \\
\text { and Hohl 1999). }\end{array}$ & Taste Disposal (Burbank \\
\hline
\end{tabular}


HNF-1901 Rev 1

\begin{tabular}{|l|l|}
\hline Assigned Document Number & Maintained Current? \\
\hline E.6 & No \\
\hline
\end{tabular}

Document Name

HNF-SD-TWR-AGA-004, Analysis of Alternatives for Immobilized Low-Activity Waste Disposal (Burbank and Klem 1997)

Responsible Organization

LMHC

Status of Preparation/Revision

Revision 0 was issued October 27, 1997.

Source Information Designation

Establishes disposal options and facilities for immobilized LAW.

\section{Brief Summary of Content}

This report presents a study of alternative disposal-system architectures and implementation strategies to provide onsite near-surface disposal capacity to receive the immobilized low-activity waste produced by the Private Contractor. The analysis shows that a flexible unit strategy that provides a suite of design solutions tailored to the characteristics of the immobilized low-activity waste will provide a disposal system that best meets the program goals of reducing the environmental, health, and safety impacts, meeting the schedule milestones, and minimizing the life-cycle cost of the program.

Inter-related documents (successors and predecessors)

HNF-3899, Immobilized High-Level Waste Interim Storage Alternatives Generation and Analysis and Decision Report (Calmus 1999a).

HNF-4003, Reanalysis of Alternatives from Immobilized Low-Activity Waste Disposal (Burbank and Hohl 1999). 
HNF-1901 Rev 1

\begin{tabular}{|l|l|}
\hline Assigned Document Number & Maintained Current? \\
\hline E.7 & No \\
\hline
\end{tabular}

Document Name

WHC-SD-WM-TA-183, High-Level Waste Interim Storage Architecture Selection - Decision Report (Calmus 1996b)

Responsible Organization

LMHC .

Status of Preparation/Revision

Revision 0 was issued September 27, 1996.

Source Information Designation

Establishes disposal options and facilities for immobilized HLW.

\section{Brief Summary of Content}

The DOE has embarked upon a course to acquire Hanford Site tank waste treatment and immobilization services using privatized facilities. This plan contains a two-phase approach. Phase 1 is a "proof of principle/commercial demonstration-scale" effort, and Phase 2 is a fullscale production effort. Interim storage and disposal of various products from privatized facilities are not included in the privatization scope. Interim storage capabilities are to be furnished by DOE. This document presents the decision and decision basis to provide for interim storage of Phase 1 high-level waste products until they can be transferred to a Federal geologic repository for disposal.

Inter-related documents (successors and predecessors)

None. 
HNF-1901 Rev 1

\begin{tabular}{|c|c|}
\hline Assigned Document Number & Maintained Current? \\
\hline E.8 & No \\
\hline \multicolumn{2}{|l|}{ Document Name } \\
\hline \multicolumn{2}{|c|}{$\begin{array}{l}\text { HNF-SD-WM-RPT-294, Decision Document for the Final Disposition of Cesium and } \\
\text { Strontium Capsules (Claghorn 1997) }\end{array}$} \\
\hline \multicolumn{2}{|l|}{ Responsible Organization } \\
\hline \multicolumn{2}{|l|}{ LMHC } \\
\hline \multicolumn{2}{|l|}{ Status of Preparation/Revision } \\
\hline \multicolumn{2}{|c|}{ Revision 0 was issued March 24, 1997.} \\
\hline \multicolumn{2}{|l|}{ Source Information Designation } \\
\hline \multicolumn{2}{|c|}{$\begin{array}{l}\text { Discusses how and when cesium-137/strontium- } 90 \text { capsules at the Hanford Site will be } \\
\text { prepared for disposal. }\end{array}$} \\
\hline \multicolumn{2}{|l|}{ Brief Summary of Content } \\
\hline \multicolumn{2}{|c|}{$\begin{array}{l}\text { This report was prepared to document decisions regarding the disposition of cesium and } \\
\text { strontium capsules. A decision support board was established to consider the multiple drivers } \\
\text { for decisions regarding disposition of cesium and strontium capsules and to make the decisions } \\
\text { that form the near-term guidance for the project. The decision process included several } \\
\text { decision board meetings, documented in this report, in which technical and programmatic } \\
\text { information was presented by Tank Waste Remediation System (TWRS) technical staff and } \\
\text { considered by the decision board. The process also included preparation of the decision } \\
\text { documentation, which is presented in this report. }\end{array}$} \\
\hline \multicolumn{2}{|c|}{ Inter-related documents (successors and predecessors) } \\
\hline \multicolumn{2}{|c|}{$\begin{array}{l}\text { Correspondence No. 97-WDD-058A, Contract Number DE-AC06-96-RL13200-Decision } \\
\text { Document for the Final Disposition of Cesium and Strontium Capsules, HNF-SD-WM-294, } \\
\text { Rev. } 0 \text { (Taylor 1997a). }\end{array}$} \\
\hline
\end{tabular}


HNF-1901 Rev 1

\begin{tabular}{|l|l|}
\hline Assigned Document Number & Maintained Current? \\
\hline E.9 & No \\
\hline
\end{tabular}

\section{Document Identification}

Technical baseline documents for Project W-464

Responsible Organization

LMHC

Status of Preparation/Revision

Various

Source Information Designation

Technical baseline documents related to the W-464 Project.

\section{Brief Summary of Content}

The project technical baseline documents are divided into 19 categories as identified below.

The categories were developed in accordance with applicable engineering plans and procedures.

1. Functional Design Criteria

WHC-SD-WM-DRD-012, Design Requirements Document for Interim Storage Phase I Solidification of High-Level Waste (Calmus 1996a)

2. Conceptual Design Report

TBD

3. Final Design Review Report

TBD

4. Alternative Design Study

TBD

5. Acceptance Test Plan reports (projects only)

TBD 
HNF-1901 Rev 1

6. Operational Test Plan

TBD

7. Operational Readiness Review/Acceptance Beneficial Use

TBD

8. Calculation/Analysis

TBD

9. Supporting Documents

70100-96-004, Environmental Requirements Checklist for the High-Level Waste Storage Project Canister Storage Building (Deffenbaugh 1996)

HNF-SD-ENV-EE-003, Permitting Plan for the Immobilized Low-Activity Waste Project (Deffenbaugh et al. 1997)

FRF049, Final CSB High-level Waste Supplemental Report (Jacobs 1996)

10. PSAR and Authorization Basis

TBD

11. Reliability, Availability, Maintainability (RAM) Analysis

TBD

12. Constructability, Operability, and Implementability Analysis

TBD

13. Vendor Drawings/Instruction Manuals

TBD

14. System Design Description

TBD

15. Spare Parts List

TBD 
HNF-1901 Rev 1

16. Control Drawings

TBD

17. Safety Equipment List

TBD

18. Construction Specifications

TBD

19. Fabrication Specifications

TBD

Inter-related documents (successors and predecessors)

To be developed. 
HNF-1901 Rev 1

\begin{tabular}{|l|l|}
\hline Assigned Document Number & Maintained Current? \\
\hline E.10 & Yes \\
\hline Document Identification \\
Technical baseline documents for Project W-465 \\
\hline Responsible Organization \\
LMHC \\
\hline Status of Preparation/Revision \\
Various \\
\hline Source Information Designation \\
Technical baseline documents related to the W-465 Project, Immobilized Low-Activity Waste \\
Interim Storage. \\
\hline Brief Summary of Content \\
The project technical baseline documents are divided into 19 categories as identified below. \\
The categories were developed in accordance with applicable engineering plans and procedures. \\
1. Functional Design Criteria \\
HNF-SD-W465-DRD-001, Design Requirements Document for Project W-465, Immobilized \\
Low-Activity Waste Interim Storage (Burbank 1997) \\
2. Conceptual Design Report \\
TBD \\
3. Alternative Design Study \\
TBD \\
4. Final Design Review Report \\
TBD \\
5. Acceptance Test Plan \\
TBD \\
\hline
\end{tabular}


HNF-1901 Rev 1

6. Operational Test Plan

TBD

7. Operational Readiness Review/Acceptance Beneficial Use

TBD

8. Calculation/Analysis

TBD

9. Supporting Documents

TBD

10. PSAR Authorization Basis

HDF-SD-W465-PSE-001, Preliminary Safety Evaluation for Project W-465, Immobilized Low-Activity Waste Interim Storage (Mouette 1997).

11. Reliability, Availability, Maintainability (RAM) Analysis

TBD

12. Constructability, Operability, and Implementability Analysis

TBD

13. Vendor Drawings/Instruction Manuals

TBD

14. System Design Description

TBD

15. Spare Parts List

TBD

16. Control Drawings

TBD

17. Safety Equipment List

TBD 
HNF-1901 Rev 1

18. Construction Specifications

TBD

19. Fabrication Specifications

TBD

Inter-related documents (successors and predecessors)

To be developed. 


\begin{tabular}{|l|l|}
\hline Assigned Document Number & Maintained Current? \\
\hline E.11 & No \\
\hline Document Name \\
WHC-SD-WM-EE-004, Performance Assessment of Grouted Double-Shell Tank Waste \\
Disposal at Hanford (Shade et al. 1994)
\end{tabular}


HNF-1901 Rev 1

\begin{tabular}{|l|l|}
\hline Assigned Document Number & Maintained Current? \\
\hline E.12 & No \\
\hline
\end{tabular}

Document Name

HNF-EP-0884, Hanford Low-Level Tank Waste Interim Performance Assessment

(Mann et al. 1997)

Responsible Organization

LMHC

Status of Preparation/Revision

Revision 1 was released in September 1997.

Source Information Designation

Examines long-term health and environmental effects associated with disposal in the Hanford Site 200 East Area of low-activity waste from single-shell tanks and double-shell tanks.

\section{Brief Summary of Content}

This report examines the long-term environmental and human-health effects associated with the disposal of the low-level fraction of the single- and double-shell tank waste in the Hanford Site 200 East Area. This report was prepared as a good management practice to provide needed information about the relationship between the disposal-system design and performance early in the disposal-system project cycle. The calculations in this performance assessment show that the disposal of the low-level fraction can meet environmental and health performance objectives.

Inter-related documents (successors and predecessors)

None. 
HNF-1901 Rev 1

\begin{tabular}{|l|l|}
\hline Assigned Document Number & Maintained Current? \\
\hline E.13 & No \\
\hline
\end{tabular}

Document Name

HNF-SD-ENV-EE-003, Permitting Plan for the Immobilized Low-Activity Waste Project (Deffenbaugh et al. 1997)

Responsible Organization

LMHC

Status of Preparation/Revision

Revision 0 was released in August 1997.

Source Information Designation

Establishes requirements, alternatives, implementation strategy, and estimated costs for environmental permits and compliance.

\section{Brief Summary of Content}

This document addresses the environmental permitting requirements for the transportation and interim storage of the immobilized low-activity waste produced during Hanford Site Privatization Phase 1.

Inter-related documents (successors and predecessors)

None. 
HNF-1901 Rev 1

\begin{tabular}{|l|l|}
\hline Assigned Document Number & Maintained Current? \\
\hline E.14 & No \\
\hline
\end{tabular}

\section{Document Name}

Correspondence No. 70100-96-004, Environmental Requirements Checklist for the High-Level Waste Storage Project Canister Storage Building (Deffenbaugh 1996)

\section{Responsible Organization}

LMHC

\section{Status of Preparation/Revision}

The document was issued via letter in November 1996.

\section{Source Information Designation}

Establishes requirements, alternatives, implementation strategy, and estimated costs for environmental permits and compliance.

\section{Brief Summary of Content}

The path forward for solidified high-level waste (HLW) interim storage entails use of the spent nuclear fuel (SNF) Canister Storage Building (CSB) for interim storage of solidified HLW produced during Privatization Phase 1. The CSB is designed as a "zero discharge" facility. Engineering assessments have indicated that excess CSB vaults (the two southern-most vaults 2 and 3) could, with some modification, be used for immobilized HLW interim storage. This environmental checklist addresses the specific storage of Phase 1 HLW products in the CSB. This permitting checklist will provide the basis to develop a permitting plan concurrent with HLW interim-storage project CSB conceptual design.

Inter-related documents (successors and predecessors)

None. 
HNF-1901 Rev 1

\begin{tabular}{|c|c|}
\hline Assigned Document Number & Maintained Current? \\
\hline E.15 & No \\
\hline \multicolumn{2}{|l|}{ Document Name } \\
\hline \multicolumn{2}{|c|}{$\begin{array}{l}\text { HNF-SD-ENV-EE-002, Permitting Plan for the High-Level Waste Interim Storage Project } \\
\text { W-464 (Deffenbaugh 1998) }\end{array}$} \\
\hline \multicolumn{2}{|l|}{ Responsible Organization } \\
\hline \multicolumn{2}{|l|}{ LMHC } \\
\hline \multicolumn{2}{|l|}{ Status of Preparation/Revision } \\
\hline \multicolumn{2}{|l|}{ Revision 1 was issued May 21, 1998.} \\
\hline \multicolumn{2}{|l|}{ Source Information Designation } \\
\hline \multicolumn{2}{|c|}{$\begin{array}{l}\text { Establishes requirements, alternatives, implementation strategy, and estimated costs for } \\
\text { environmental permits and compliance. }\end{array}$} \\
\hline \multicolumn{2}{|l|}{ Brief Summary of Content } \\
\hline \multicolumn{2}{|c|}{$\begin{array}{l}\text { This permitting and approvals plan describes the environmental permitting activities necessary } \\
\text { for the transportation and interim storage of (1) immobilized high-level waste (IHLW), } \\
\text { produced primarily during Phase } 1 \text { vitrification plant operations (glass product), (2) radioactive } \\
\text { cesium, separated during Phase } 1 \text { low-activity waste (LAW) vitrification plant operation } \\
\text { (separated cesium), and (3) secondary high-level radioactive and mixed waste, produced during } \\
\text { Phase } 1 \text { (high-level waste [HLW] and LAW vitrification plant operations (nonroutine HLW). } \\
\text { Secondary or nonroutine HLW is expected to consist primarily of refractory and solidified glass } \\
\text { from failed melters. }\end{array}$} \\
\hline \multicolumn{2}{|l|}{ This plan has several objectives, including the following: } \\
\hline $\begin{array}{l}\text { - Identification of the necessary permitting activit } \\
\text { - Evaluation of the current permitting status for II } \\
\text { - Identification of options and strategies to compl } \\
\text { - Recommended course of action for each of the } \\
\text { - Estimated time required to undertake those pern } \\
\text { - Estimated cost to implement the permitting acti }\end{array}$ & $\begin{array}{l}\text { vities } \\
\text { vironmental requirements } \\
\text { ermitting activities } \\
\text { ivities }\end{array}$ \\
\hline \multicolumn{2}{|l|}{ Inter-related documents (successors and predecessors) } \\
\hline & \\
\hline
\end{tabular}


HNF-1901 Rev 1

\begin{tabular}{|l|l|}
\hline Assigned Document Number & Maintained Current? \\
\hline E.16 & No \\
\hline
\end{tabular}

Document Name

96-SFD-104, Memorandum of Agreement (MOA) - Utilization of Canister Storage Building (CSB) Vaults 2 and 3 for Immobilized High-Level Tank Waste (Hansen 1996)

\section{Responsible Organization}

LMHC

Status of Preparation/Revision

The DOE memorandum of agreement was issued via letter in April 1996.

\section{Source Information Designation}

Describes the attributes of Vaults 2 and 3 of the CSB and discusses features to facilitate addition of more vaults later.

\section{Brief Summary of Content}

This memorandum of agreement deals with the use of available vaults in the Canister Storage Building (CSB) for interim storage of immobilized high-level waste products and other potential products from Privatization Phase 1 treatment of tank wastes.

The Spent Nuclear Fuel (SNF) Project restarted construction of the CSB after a partial redesign to accommodate SNF, including partitioning the storage area into three vaults by the addition of walls below the deck. The overall superstructure will include services such as overhead cranes for all vaults. The north vault (vault 1) will provide sufficient storage space for anticipated Hanford Site SNF.

A new baseline approach subsequently was established for tank waste remediation, based on privatization of tank waste treatment in two phases. Phase 1 includes an option for immobilization of high-level waste (HLW) over a period of five to nine years, with production starting in July 2002. At the projected rate of one metric ton of product per day, the two available units in the CSB would have sufficient space for the HLW products, including secondary products (separated radionuclides) and other miscellaneous HLW forms (e.g., waste materials from failed melters) to be generated in Phase 1. Various alternatives for interim storage of Phase 1 canisters were evaluated with the conclusion that completing and using CSB vaults 2 and 3 was viable and was the most cost-effective alternative.

Inter-related documents (successors and predecessors)

None. 
HNF-1901 Rev 1

APPENDIX F

SECONDARY WASTE MANAGEMENT AND ANALYTICAL SUPPORT DOCUMENTS 


\section{HNF-1901 Rev 1}

This page intentionally left blank.

F-ii 
HNF-1901 Rev 1

\begin{tabular}{|l|l|}
\hline Assigned Document Number & Maintained Current? \\
\hline F.1 & Yes \\
\hline Document Name \\
HNF-SD-WM-RPT-288, Waste Management Project Technical Baseline Description \\
(Sederburg 1997) \\
\hline Responsible Organization \\
WMH \\
\hline Status of Preparation/Revision \\
Revision 0 was issued in August 1997, the document to be revised as needed. \\
\hline $\begin{array}{l}\text { Source Information Designation } \\
\text { Official source for information relating to Waste Management Federal Services of Hanford, } \\
\text { Incorporated (WMH), activities, including ETF/LERF, 242-A Evaporator, CWC, and 222-S } \\
\text { Laboratories. }\end{array}$ \\
\hline $\begin{array}{l}\text { Brief Summary of Content } \\
\text { The document uses a systems engineering approach to establish the Project's technical } \\
\text { baseline. This document views the Project as a single system and documents the elements } \\
\text { needed to successfully manage a project of this magnitude. By defining the Project's baseline, } \\
\text { the effects of uncertainties and internally and externally driven changes to key Project } \\
\text { elements can be understood. In turn, effects of these changes on the mission, function, } \\
\text { interfaces, etc. can be assessed and controlled. }\end{array}$ \\
\hline $\begin{array}{l}\text { Inter-related documents (successors and predecessors) } \\
\text { To be developed. }\end{array}$ \\
\hline
\end{tabular}


HNF-1901 Rev 1

\begin{tabular}{|c|c|}
\hline Assigned Document Number & Maintained Current? \\
\hline F.2 & Yes \\
\hline \multicolumn{2}{|l|}{ Document Name } \\
\hline \multicolumn{2}{|c|}{$\begin{array}{l}\text { HNF-EP-0918, Rev. 6, Solid Waste Integrated Forecast Technical (SWIFT) Report FY } 2000 \\
\text { to FY } 2046 \text { (Barcot 1999) }\end{array}$} \\
\hline \multicolumn{2}{|l|}{ Responsible Organization } \\
\hline \multicolumn{2}{|l|}{ WMH } \\
\hline \multicolumn{2}{|l|}{ Status of Preparation/Revision } \\
\hline \multicolumn{2}{|c|}{ Revision 6 was issued in August 1999, document to be revised as needed. } \\
\hline \multicolumn{2}{|l|}{ Source Information Designation } \\
\hline \multicolumn{2}{|c|}{ Source for solid-waste-generation predictions. } \\
\hline \multicolumn{2}{|l|}{ Brief Summary of Content } \\
\hline \multicolumn{2}{|c|}{$\begin{array}{l}\text { Provides Hanford Site solid-waste-generation estimates, based on the type of waste, } \\
\text { generating facility, and year. This document is currently available on the Internet at } \\
\text { http://w3.pnl.gov.2080/swift/welcome.htm. }\end{array}$} \\
\hline \multicolumn{2}{|c|}{ Inter-related documents (successors and predecessors) } \\
\hline To be developed. & \\
\hline
\end{tabular}


HNF-1901 Rev 1

APPENDIX G

REFERENCES 


\section{HNF-1901 Rev 1}

This page intentionally left blank. 


\section{APPENDIX G}

\section{REFERENCES}

\begin{tabular}{|l|l|}
\hline & Acts \\
\hline National Environmental Policy Act of 1969, as amended, 42 USC 4321 et seq. \\
\hline Resource Conservation and Recovery Act of 1976 , as amended, 42 USC 6901 et seq. \\
\hline
\end{tabular}

\section{Code of Federal Regulations}

40 CFR 61.96, "National Emission Standards for Hazardous Air Pollutants; Applications to Construct or Modify," Code of Federal Regulations, as amended.

40 CFR 261, "Identification and Listing of Hazardous Waste," Code of Federal Regulations, as amended.

40 CFR 265, "Interim Status Standards for Owners and Operators of Hazardous Waste Treatment, Storage, and Disposal Facilities," Code of Federal Regulations, as amended.

40 CFR 268, "Land Disposal Restrictions," Code of Federal Regulations, as amended.

\section{Federal Register}

62 FR 8693, 1997, "Record of Decision for the Tank Waste Remediation System, Hanford Site, Richland, WA" Federal Register, Vol. 62, pp. 8693-8704 (February 26).

\section{Washington Administrative Codes}

WAC 173-216, "State Waste Discharge Permit Program," Washington Administrative Code, as amended.

WAC 173-460, "Controls for New Sources of Toxic Air Pollutants," Washington Administrative Code, as amended.

WAC 246-247, "Radiation Protection-Air Emissions," Washington Administrative Code, as amended. 


\section{U.S. Department of Energy Directives}

DOE O 425.1, : Startup and Restart of Nuclear Facilities, U.S. Department of Energy, Washington, D.C.

DOE O 430.1A, Life Cycle Asset Management, U.S. Department of Energy, Washington, D.C.

DOE Order 5480.22, Technical Safety Requirements, U.S. Department of Energy, Washington, D.C.

DOE Order 5480.23, Nuclear Safety Analysis Reports, U.S. Department of Energy, Washington, D.C.

GPG-FM-002, Critical Decision Criteria, Life Cycle Asset Management, Good Practice Guide, U.S. Department of Energy, Washington, D.C.

\section{Databases}

HSTD, n.d., Hanford Site Technical Baseline Database, database maintained by Lockheed Martin Hanford Corporation for Fluor Daniel Hanford, Inc., Richland, Washington.

JCS, n.d., Hanford Site Job Control System, database maintained by Fluor Daniel Hanford, Inc., Richland, Washington.

\section{Drawings}

Fluor Daniel Hanford, Inc., Richland, Washington

- Drawing No. H-2-80936, Rev. 3, Area Map Drawing List (1997)

- Drawing No. H-2-78870, Rev. 3, TWRS Top Drawing Index (1997)

- Drawing No. H-2-79207, Rev. 2, TWRS Drawing Index Tank AZ-101 Drywell/Profile Thermocouple (1997)

- Drawing No. H-2-822200, Sheets 1 and 2, Rev. 3, Drawing List (1998)

- Drawing No. H-2-818423, Project W-320 Drawing List (1997)

Lockheed Martin Hanford Corporation for Fluor Daniel Hanford, Inc., Richland, Washington

- Drawing No. H-2-131000, Rev. 1, Drawing List (1997) 


\section{HNF-1901 Rev 1}

\section{Drawings}

Westinghouse Hanford Company, Richland, Washington

- Drawing No. H-2-79335, Rev. 1, TWRS - Drawing Index 4-6" Tank 101-AZ Waste Retrieval System (1996)

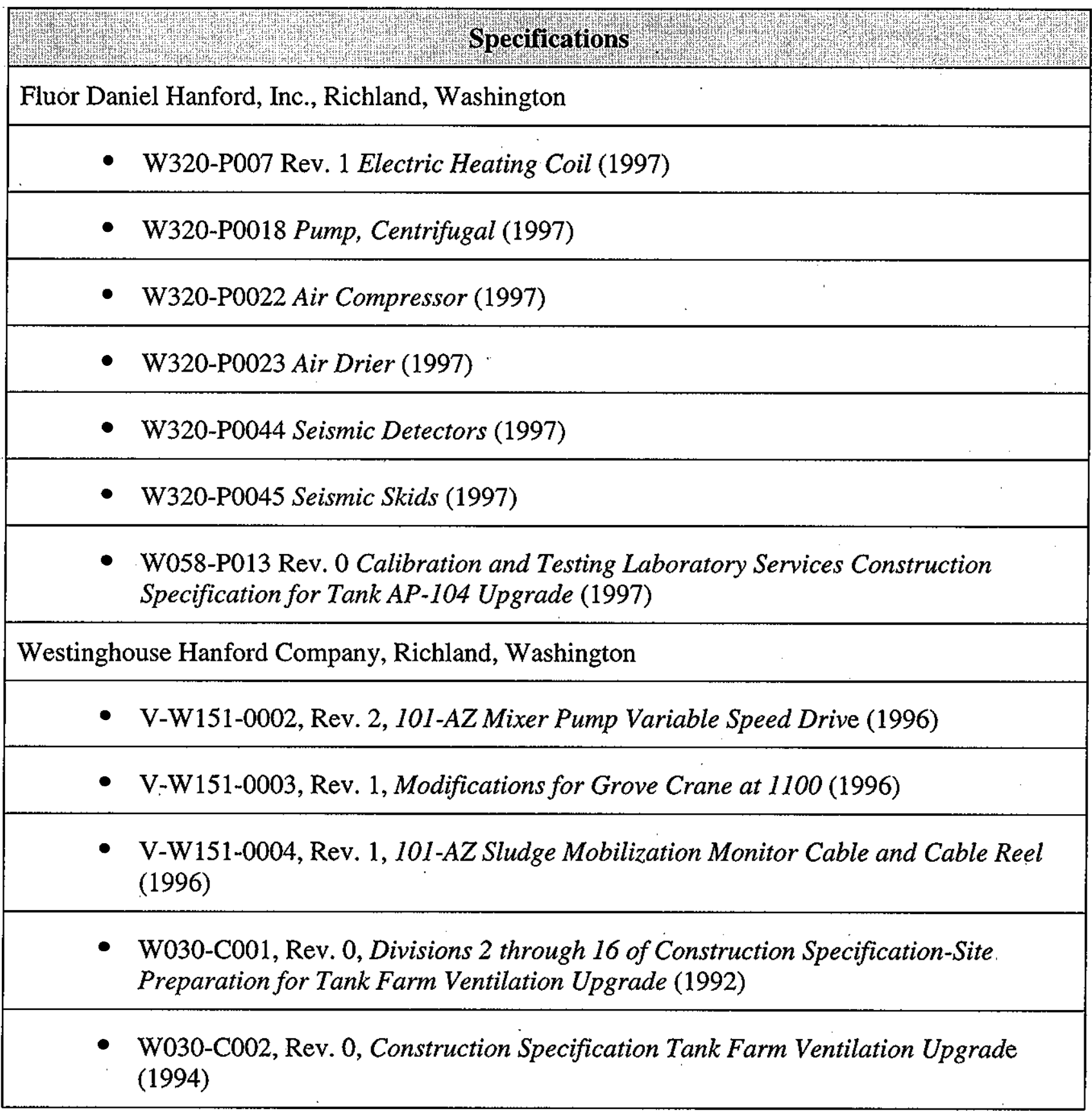


HNF-1901 Rev 1

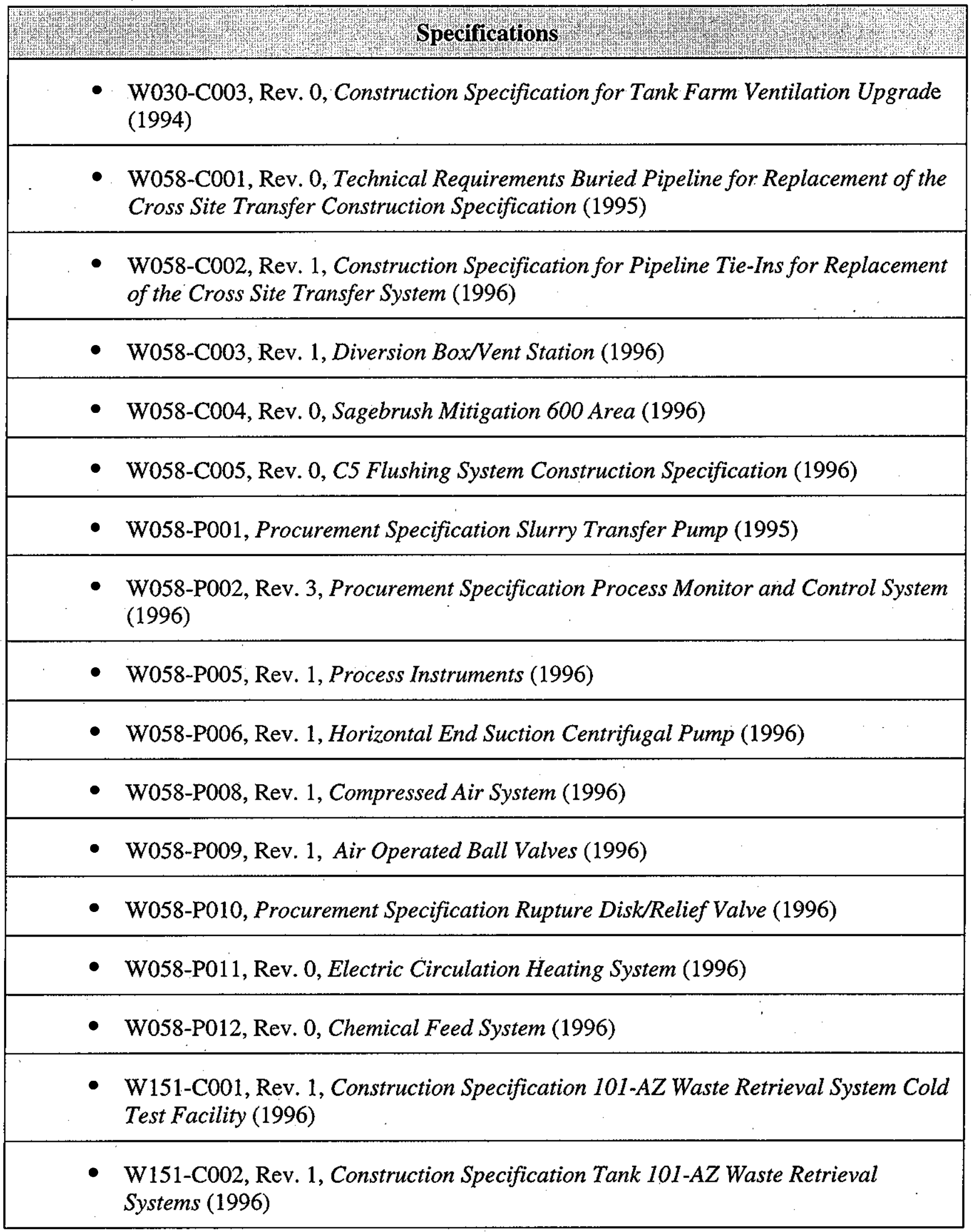


HNF-1901 Rev 1

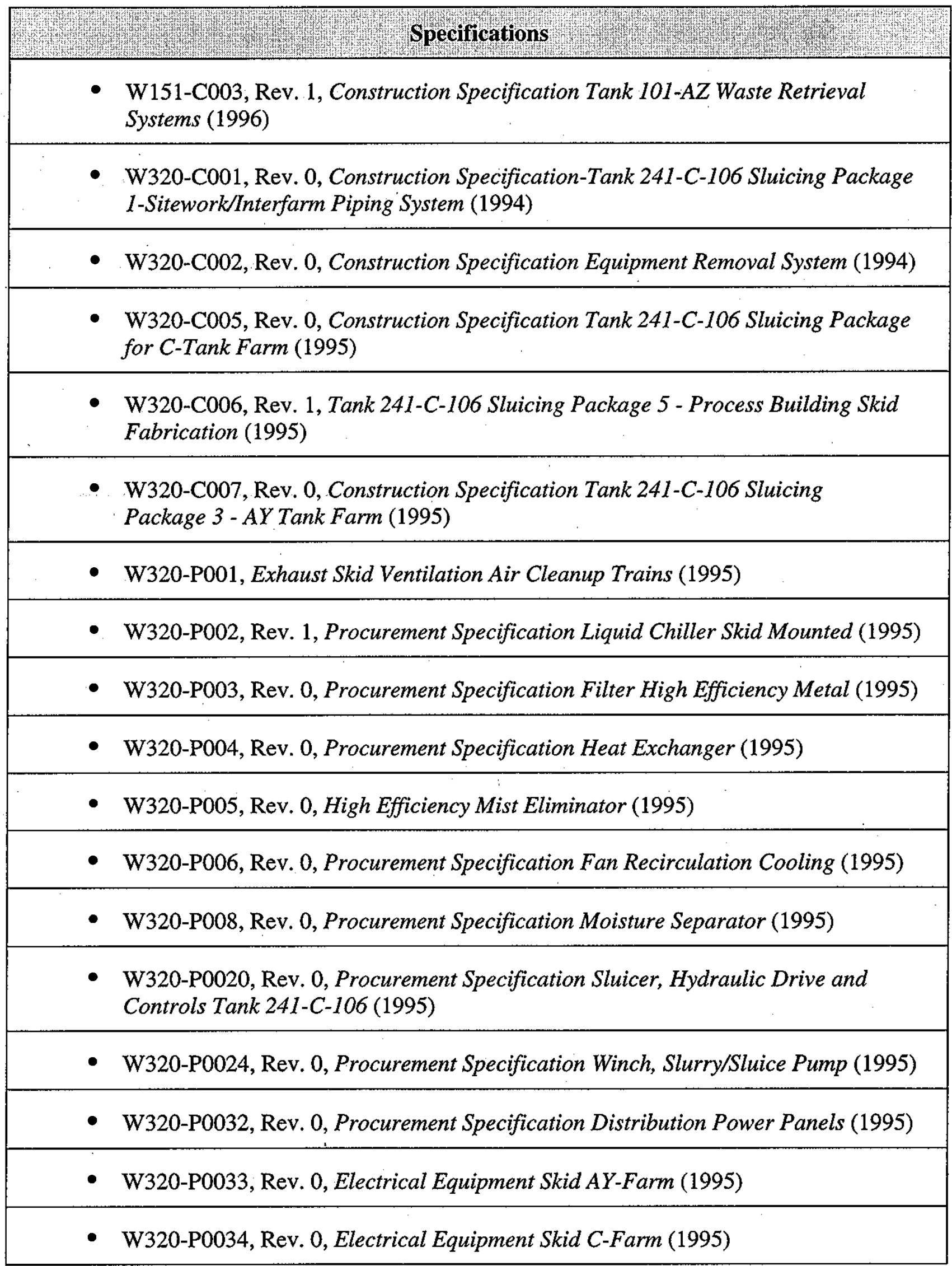




\section{HNF-1901 Rev 1}

\section{Specifications}

- W320-P0035, Rev. 0, Procurement Specification Seismic Shutdown System (1995)

- W320-P0036, Rev. 0, Procurement Specification Enclosure Environmental Control (1995)

- W320-P0041, Rev. 0, Isokinetic Air Sampling System (1995)

- W320-P017, Rev. 1, Tank 241-C-106 Sluicing (1995)

- WHC-S-0037, Rev. 3, High Pressure Hot Waste System Project W151 Tank 101-AZ Waste Retrieval System (1996)

- WHC-S-0040, Rev. 1, Waste Mobilization Mixer Pump Project W151 Tank AZ-101 Waste Retrieval System (1996)

- WHC-S-0099, Rev. 2, Waste Tank Riser - Drywell Mapping Positioner (1994)

- WHC-S-0410, Rev. 2, Procurement Specification for the 241-AZ-101, W-151 Suspended Fixture and Weld Specification Camera System (1996)

\section{Tank Characterization Reports: Best-Basis Inventory}

Baldwin, J. H., 1995a, Tank Characterization Report for Double-Shell Tank 241-AW-101, WHC-SD-WM-ER-470, Rev. 0, Westinghouse Hanford Company, Richland, Washington.

Baldwin, J. H., 1995b, Tank Characterization Report for Single-Shell Tank 241-SX-113, WHC-SD-WM-ER-480, Rev. 0, Westinghouse Hanford Company, Richland, Washington.

Baldwin, J. H., 1996a, Tank Characterization Report for Double-Shell Tank 241-AP-108, WHC-SD-WM-ER-593, Rev. 0, Westinghouse Hanford Company, Richland, Washington.

Baldwin, J. H., 1996b, Tank Characterization Report for Single-Shell Tank 241-BY-108, WHC-SD-WM-ER-533, Rev. 0, Westinghouse Hanford Company, Richland, Washington.

Baldwin, J. H., 1996c, Tank Characterization Report for Single-Shell Tank 241-T-108, WHC-SD-WM-ER-554, Rev. 0, Westinghouse Hanford Company, Richland, Washington. 


\section{Tank Characterization Reports: Best-Basis Inventory}

Baldwin, J. H., 1996d, Tank Characterization Report for Single-Shell Tank 241-U-109, WHC-SD-WM-ER-609, Rev. 0, Westinghouse Hanford Company, Richland, Washington.

Baldwin, J. H., 1997a, Tank Characterization Report for Double-Shell Tank 241-AP-102, HNF-SD-WM-ER-358, Rev. 1, prepared by Lockheed Martin Hanford Corporation for Fluor Daniel Hanford Inc., Richland, Washington.

Baldwin, J. H., 1997b, Tank Characterization Report for Single-Shell Tank 241-BY-112, HNF-SD-WM-ER-701, Rev. 0, prepared by Lockheed Martin Hanford Corporation for Fluor Daniel Hanford, Inc., Richland, Washington.

Baldwin, J. H., 1997c, Tank Characterization Report for Single-Shell Tank 241-C-104, HNF-SD-WM-ER-679, Rev. 0, prepared by Lockheed Martin Hanford Corporation for Fluor Daniel Hanford, Inc., Richland, Washington.

Baldwin, J. H., 1997d, Tank Characterization Report for Single-Shell Tank 241-T-102, HNF-SD-WM-ER-700, Rev. 0, prepared by Lockheed Martin Hanford Corporation for Fluor Daniel Hanford, Inc., Richland, Washington.

Bell, K. E., 1995, Tank Characterization Report for Single-Shell Tank 241-C-107, WHC-SD-WM-ER-474, Rev. 0, Westinghouse Hanford Company, Richland, Washington.

Bell, K. E., 1996a, Tank Characterization Report for Single-Shell Tank 241-BX-103, WHC-SD-WM-ER-535, Rev. 0, Westinghouse Hanford Company, Richland, Washington.

Bell, K. E., 1996b, Tank Characterization Report for Single-Shell Tank 241-BY-106, WHC-SD-WM-ER-616, Rev. 0, Westinghouse Hanford Company, Richland, Washington.

Bell, K. E., 1997a, Tank Characterization Report for Double-Shell Tank 241-AW-102, HNF-SD-WM-ER-363, Rev. 1, prepared by Lockheed Martin Hanford Corporation for Fluor Daniel Hanford, Inc., Richland, Washington.

Bell, K. E., 1997b, Tank Characterization Report for Single-Shell Tank 241-U-108, HNF-SD-WM-ER-639, Rev. 0, prepared by Lockheed Martin Hanford Corporation for Fluor Daniel Hanford Inc., Richland, Washington.

Bell, K. E., 1997c, Tank Characterization Report for Single-Shell Tank 241-U-110, HNF-SD-WM-ER-551, Rev. 1, prepared by Lockheed Martin Hanford Corporation for Fluor Daniel Hanford Inc., Richland, Washington. 


\section{HNF-1901 Rev 1}

\section{Tank Characterization Reports: Best-Basis Inventory}

Benar, C. J., 1996a, Tank Characterization Report for Double-Shell Tank 241-AN-101, WHC-SD-WM-ER-578, Rev. 0, Westinghouse Hanford Company, Richland, Washington.

Benar, C. J., 1996b, Tank Characterization Report for Single-Shell Tank 241-BY-104, WHC-SD-WM-ER-608, Rev. 0, Westinghouse Hanford Company, Richland, Washington.

Benar, C. J., 1997a, Tank Characterization Report for Single-Shell Tank 241-B-109, HNF-SD-WM-ER-677, Rev. 0, prepared by Lockheed Martin Hanford Corporation for Fluor Daniel Hanford, Inc., Richland, Washington.

Benar, C. J., 1997b, Tank Characterization Report for Single-Shell Tank 241-B-111, HNF-SD-WM-ER-549, Rev. 1, prepared by Lockheed Martin Hanford Corporation for Fluor Daniel Hanford, Inc., Richland, Washington.

Benar, C. J., 1997c, Tank Characterization Report for Single-Shell Tank 241-C-110, HNF-SD-WM-ER-367, Rev. 1, prepared by Lockheed Martin Hanford Corporation for Fluor Daniel Hanford, Inc., Richland, Washington.

Boldt, A. L., 1997, Preliminary Tank Characterization Report for Single-Shell Tank 241-T-112: Best-Basis Inventory, HNF-SD-WM-ER-699, Rev. 0, prepared by Lockheed Martin Hanford Corporation for Fluor Daniel Hanford, Inc., Richland, Washington.

Brown, T. M., 1995, Tank Characterization Report for Single-Shell Tank 241-U-105, WHC-SD-WM-ER-617, Rev. 0, Westinghouse Hanford Company, Richland, Washington.

Brown, T. M., 1996, Tank Characterization Report for Single-Shell Tank 241-T-109, WHC-SD-WM-ER-559, Rev. 0, Westinghouse Hanford Company, Richland, Washington.

Brown, T. M., 1997, Tank Characterization Report for Single-Shell Tank 241-U-106, HNF-SD-WM-ER-636, Rev. 0, prepared by Lockheed Martin Hanford Corporation for Fluor Daniel Hanford Inc., Richland, Washington.

Conner, J. M., 1995, Tank Characterization Report for Single-Shell Tank 241-B-103, WHC-SD-WM-ER-488, Rev. 0, Westinghouse Hanford Company, Richland, Washington.

Conner, J. M., 1996a, Tank Characterization Report for Double-Shell Tank 241-SY-103, WHC-SD-WM-ER-471, Rev. 1, Westinghouse Hanford Company, Richland, Washington. 
Conner, J. M., 1996b, Tank Characterization Report for Single-Shell Tank 241-C-204, WHC-SD-WM-ER-479, Rev. 0, Westinghouse Hanford Company, Richland, Washington.

Conner, J. M., 1997a, Tank Characterization Report for Double-Shell Tank 241-AP-101, HNF-SD-WM-ER-357, Rev. 1, prepared by Lockheed Martin Hanford Corporation for Fluor Daniel Hanford Inc., Richland, Washington.

Conner, J. M., 1997b, Tank Characterization Report for Single-Shell Tank 241-B-201, HNF-SD-WM-ER-550, Rev. 1, prepared by Lockheed Martin Hanford Corporation for Fluor Daniel Hanford, Inc., Richland, Washington.

Conner, J. M., 1997c, Tank Characterization Report for Single-Shell Tank 241-S-111, HNF-SD-WM-ER-638, Rev. 0, prepared by Lockheed Martin Hanford Corporation for Fluor Daniel Hanford, Inc., Richland, Washington.

Dougherty, L. F., 1995a, Tank Characterization Report for Single-Shell Tank 241-B-202, HNF-SD-WM-ER-371, Rev. 0, Westinghouse Hanford Company, Richland, Washington.

Dougherty, L. F., 1995b, Tank Characterization Report for Single-Shell Tank 241-B-112, WHC-SD-WM-ER-466, Rev. 0, Westinghouse Hanford Company, Richland, Washington.

Douglas, J. G., 1997, Tank Characterization Report for Double-Shell Tank 241-AN-106, WHC-SD-WM-ER-569, Rev. 0, Westinghouse Hanford Company, Richland, Washington.

Eggers, R. F., 1995, Tank Characterization Report for Single-Shell Tank 241-S-102, WHC-SD-WM-ER-611, Rev. 0, Westinghouse Hanford Company, Richland, Washington.

Eggers, R. F., 1996, Tank Characterization Report for Single-Shell Tank 241-SX-108, WHC-SD-WM-ER-582, Rev. 0, Westinghouse Hanford Company, Richland, Washington.

Field, J. G., 1996a, Tank Characterization Report for Single-Shell Tank 241-B-104, WHC-SD-WM-ER-552, Rev. 0, Westinghouse Hanford Company, Richland, Washington.

Field, J. G., 1996b, Tank Characterization Report for Single-Shell Tank 241-BX-109, WHC-SD-ER-572, Rev. 0, Westinghouse Hanford Company, Richland, Washington.

Field, J. G., 1996c, Tank Characterization Report for Single-Shell Tank 241-BY-105, WHC-SD-WM-ER-598, Rev. 0, Westinghouse Hanford Company, Richland, Washington. 
Field, J. G, 1997a, Tank Characterization Report for Double-Shell Tank 24l-AP-103, HNF-SD-WM-ER-359, Rev. 1, prepared by Lockheed Martin Hanford Corporation for Fluor Daniel Hanford Inc., Richland, Washington.

Field, J. G., 1997b, Tank Characterization Report for Double-Shell Tank 241-AP-107, HNF-SD-WM-ER-362, Rev. 1, prepared by Lockheed Martin Hanford Corporation for Fluor Daniel Hanford Inc., Richland, Washington.

Field, J. G., 1997c, Tank Characterization Report for Double-Shell Tank 241-AP-107, HNF-SD-WM-ER-365, Rev. 1, prepared by Lockheed Martin Hanford Corporation for Fluor Daniel Hanford Inc., Richland, Washington.

Field, J. G., 1997d, Tank Characterization Report for Single-Shell Tank 241-A-101, HNF-SD-WM-ER-673, Rev. 0, prepared by Lockheed Martin Hanford Corporation for Fluor Daniel Hanford, Inc., Richland, Washington.

Field, J. G., 1997e, Tank Characterization Report for Single-Shell Tank 241-B-110, HNF-SD-WM-ER-368, Rev. 1, prepared by Lockheed Martin Hanford Corporation for Fluor Daniel Hanford, Inc., Richland, Washington.

Field, J. G., 1997f, Tank Characterization Report for Single-Shell Tank 241-S-104, HNF-SD-WM-ER-370, Rev. 1, prepared by Lockheed Martin Hanford Corporation for Fluor Daniel Hanford, Inc., Richland, Washington.

Field, J. G., 1997g, Tank Characterization Report for Single-Shell Tank 241-S-109, HNF-SD-WM-ER-627, Rev. 0, prepared by Lockheed Martin Hanford Corporation for Fluor Daniel Hanford, Inc., Richland, Washington.

Field, J. G., 1997h, Tank Characterization Report for Single-Shell Tank 241-T-105, HNF-SD-WM-ER-369, Rev. 1, prepared by Lockheed Martin Hanford Corporation for Fluor Daniel Hanford; Inc., Richland, Washington.

Field, J. G., 1997i, Tank Characterization Report for Single-Shell Tank 241-T-111, HNF-SD-WM-ER-540, Rev. 1, prepared by Lockheed Martin Hanford Corporation for Fluor Daniel Hanford, Inc., Richland, Washington.

Hall, B. W., 1995a, Tank Characterization Report for Single-Shell Tank 241-BX-105, WHC-SD-WM-ER-406, Rev. 0, Westinghouse Hanford Company, Richland, Washington.

Hall, B. W., 1995b, Tank Characterization Report for Single-Shell Tank 241-C-101, WHC-SD-WM-ER-473, Rev. 0, Westinghouse Hanford Company, Richland, Washington. 


\section{Tank Characterization Reports: Best-Basis Inventory}

Hendrickson, D. W., 1997, Preliminary Tank Characterization Report for Single-Shell Tank 241-TX-103: Best-Basis Inventory, HNF-SD-WM-ER-704, Rev. 0, prepared by SGN Eurisys Services for Fluor Daniel Hanford, Inc., Richland, Washington.

Herting, D. L., 1995, Tank Characterization Report for Double-Shell Tank 241-SY-101, WHC-SD-WM-ER-409, Rev. 0, Westinghouse Hanford Company, Richland, Washington.

Higley, B. A., 1997a, Preliminary Tank Characterization Report for Single-Shell Tank 241-A-103: Best Basis Inventory, HNF-SD-WM-ER-709, Rev. 0, prepared by Waste Management Federal Services of Hanford for Fluor Daniel Hanford, Inc., Richland, Washington.

Higley, B. A., 1997b, Preliminary Tank Characterization Report for Single-Shell Tank 241-B-105: Best-Basis Inventory, HNF-SD-WM-ER-722, Rev. 0, prepared by Lockheed Martin Hanford Corporation for Fluor Daniel Hanford, Inc., Richland, Washington.

Hodgson, K. M., 1995a, Tank Characterization Report for Double-Shell Tank 241-AW-103, WHC-SD-WM-ER-455, Rev. 0, Westinghouse Hanford Company, Richland, Washington.

Hodgson, K. M., 1995b, Tank Characterization Report for Double-Shell Tank 241-AZ-101, WHC-SD-WM-ER-410, Rev. 0, Westinghouse Hanford Company, Richland, Washington.

Hodgson, K. M., 1997, Preliminary Tank Characterization Report for Single-Shell Tank 241-A-104: Best Basis Inventory, HNF-SD-WM-ER-666, Rev. 0, prepared by Lockheed Martin Hanford Corporation for Fluor Daniel Hanford, Inc., Richland, Washington.

Hodgson, K. M. and J. G. Field, 1997, Preliminary Tank Characterization Report for Single-Shell Tank 241-A-105: Best Basis Inventory, HNF-SD-WM-ER-667, Rev. 0, prepared by Lockheed Martin Hanford Corporation for Fluor Daniel Hanford, Inc., Richland, Washington.

Hu, T. A., 1996, Tank Characterization Report for Single-Shell Tank 241-BX-104, WHC-SD-WM-ER-599, Rev. 0, Westinghouse Hanford Company, Richland, Washington.

Hu, T. A., 1997a, Tank Characterization Report for Double-Shell Tank 241-AP-105, HNF-SD-WM-ER-360, Rev. 1, prepared by Lockheed Martin Hanford Corporation for Fluor Daniel Hanford Inc., Richland, Washington.

Hu, T. A., 1997b, Tank Characterization Report for Single-Shell Tank 241-U-102, HNF-SD-WM-ER-618, Rev. 0, prepared by Lockheed Martin Hanford Corporation for Fluor Daniel Hanford Inc., Richland, Washington. 


\section{Tank Characterization Reports: Best-Basis Inventory}

Jo, J., 1995, Tank Characterization Report for Single-Shell Tank 24l-TY-106,

WHC-SD-WM-ER-482, Rev. 0, Westinghouse Hanford Company, Richland,

Washington.

Jo, J., 1996a, Tank Characterization Report for Single-Shell Tank 241-A-102,

WHC-SD-WM-ER-597, Rev. 0, Westinghouse Hanford Company, Richland,

Washington.

Jo, J., 1996b, Tank Characterization Report for Double-Shell Tank 241-AN-102,

WHC-SD-WM-ER-545, Rev. 1, Westinghouse Hanford Company, Richland,

Washington.

Jo, J., 1996c, Tank Characterization Report for Double-Shell Tank 241-AN-107,

WHC-SD-WM-ER-600, Rev. 0, Westinghouse Hanford Company, Richland,

Washington.

Jo, J., 1996d, Tank Characterization Report for Single-Shell Tank 241-B-203,

WHC-SD-WM-ER-587, Rev. 0, Westinghouse Hanford Company, Richland,

Washington.

Jo, J., 1996e, Tank Characterization Report for Single-Shell Tank 241-T-106,

WHC-SD-WM-ER-544, Rev. 0, Westinghouse Hanford Company, Richland,

Washington.

Jo, J., 1996f, Tank Characterization Report for Single-Shell Tank 241-U-107,

WHC-SD-WM-ER-614, Rev. 0, Westinghouse Hanford Company, Richland,

Washington.

Jo, J., 1997a, Tank Characterization Report for Double-Shell Tank 241-AN-105,

HNF-SD-WM-ER-678, Rev. 0, prepared by Lockheed Martin Hanford Corporation for

Fluor Daniel Hanford Inc., Richland, Washington.

Jo, J., 1997b, Tank Characterization Report for Single-Shell Tank 241-BY-111,

HNF-SD-WM-ER-687, Rev. 0, prepared by Lockheed Martin Hanford Corporation for

Fluor Daniel Hanford, Inc., Richland, Washington.

Jo, J., 1997c, Tank Characterization Report for Single-Shell Tank 241-T-104,

HNF-SD-WM-ER-372, Rev. 1, prepared by Lockheed Martin Hanford Corporation for

Fluor Daniel Hanford, Inc., Richland, Washington.

Jo, J., 1997d, Preliminary Tank Characterization Report for Single-Shell Tank 241-TX-108:

Best-Basis Inventory, HNF-SD-WM-ER-717, Rev. 0, prepared by Lockheed Martin

Hanford Corporation for Fluor Daniel Hanford, Inc., Richland, Washington. 
Kruger, A. A., 1996, Tank Characterization Report for Single-Shell Tank 241-S-101, WHC-SD-WM-ER-613, Rev. 0, Westinghouse Hanford Company, Richland, Washington.

Kupfer, M. J., 1997a, Preliminary Tank Characterization Report for Single-Shell Tank 241-A-106: Best Basis Inventory, HNF-SD-WM-ER-721, Rev. 0, prepared by Lockheed Martin Hanford Corporation for Fluor Daniel Hanford, Inc., Richland, Washington.

Kupfer, M. J., 1997b, Tank Characterization Report for Double-Shell Tank 241-AN-104, HNF-SD-WM-ER-690, Rev. 0, prepared by Lockheed Martin Hanford Corporation for Fluor Daniel Hanford Inc., Richland, Washington.

Kupfer, M. J., 1997c, Preliminary Tank Characterization Report for Single-Shell Tank 241-B-107: Best Basis Inventory, HNF-SD-WM-ER-723, Rev. 0, prepared by Lockheed Martin Hanford Corporation for Fluor Daniel Hanford, Inc., Richland, Washington.

Kupfer, M. J., 1997d, Preliminary Tank Characterization Report for Single-Shell Tank 241-BX-102: Best-Basis Inventory, HNF-SD-WM-ER-724, Rev. 0, prepared by Lockheed Martin Hanford Corporation for Fluor Daniel Hanford, Inc., Richland, Washington.

Kupfer, M. J., 1997e, Preliminary Tank Characterization Report for Single-Shell Tank 241-BX-111: Best-Basis Inventory, HNF-SD-WM-ER-653, Rev. 0, prepared by Lockheed Martin Hanford Corporation for Fluor Daniel Hanford, Inc., Richland, Washington.

Kupfer, M. J., 1997f, Preliminary Tank Characterization Report for Single-Shell Tank 241-BY-101: Best-Basis Inventory, HNF-SD-WM-ER-647, Rev. 0, prepared by Lockheed Martin Hanford Corporation for Fluor Daniel Hanford, Inc., Richland, Washington.

Kupfer, M. J., 1997g, Preliminary Tank Characterization Report for Single-Shell Tank 241-BY-103: Best-Basis Inventory, HNF-SD-WM-ER-663, Rev. 0, prepared by Lockheed Martin Hanford Corporation for Fluor Daniel Hanford, Inc., Richland, Washington.

Kupfer, M. J., 1997h, Preliminary Tank Characterization Report for Single-Shell Tank 241-BY-109: Best-Basis Inventory, HNF-SD-WM-ER-648, Rev. 0, prepared by Lockheed Martin Hanford Corporation for Fluor Daniel Hanford, Inc., Richland, Washington. 
Tank Characterization Reports: Best-Basis Inventory

Kupfer, M. J., 1997i, Preliminary Tank Characterization Report for Single-Shell Tank 241-S-103: Best-Basis Inventory, HNF-SD-WM-ER-668, Rev. 0, prepared by Lockheed Martin Hanford Corporation for Fluor Daniel Hanford, Inc., Richland, Washington.

Kupfer, M. J., 1997j, Preliminary Tank Characterization Report for Single-Shell Tank 241-S-105: Best-Basis Inventory, HNF-SD-WM-ER-669, Rev. 0, prepared by Lockheed Martin Hanford Corporation for Fluor Daniel Hanford, Inc., Richland, Washington.

Kupfer, M. J., 1997k, Preliminary Tank Characterization Report for Single-Shell Tank 241-S-106: Best-Basis Inventory, HNF-SD-WM-ER-714, Rev. 0, prepared by Lockheed Martin Hanford Corporation for Fluor Daniel Hanford, Inc., Richland, Washington.

Kupfer, M. J., 19971, Preliminary Tank Characterization Report for Single-Shell Tank 241-S-108: Best-Basis Inventory, HNF-SD-WM-ER-641, Rev. 0, prepared by Lockheed Martin Hanford Corporation for Fluor Daniel Hanford, Inc., Richland, Washington.

Kupfer, M. J., 1997m, Preliminary Tank Characterization Report for Single-Shell Tank 241-S-110: Best-Basis Inventory, HNF-SD-WM-ER-642, Rev. 0, prepared by Lockheed Martin Hanford Corporation for Fluor Daniel Hanford, Inc., Richland, Washington.

Kupfer, M. J., 1997n, Preliminary Tank Characterization Report for Single-Shell Tank 241-S-112: Best-Basis Inventory, HNF-SD-WM-ER-670, Rev. 0, prepared by Lockheed Martin Hanford Corporation for Fluor Daniel Hanford, Inc., Richland, Washington.

Kupfer, M. J., 1997o, Preliminary Tank Characterization Report for Single-Shell Tank 241-SX-101: Best-Basis Inventory, HNF-SD-WM-ER-660, Rev. 0, prepared by Lockheed Martin Hanford Corporation for Fluor Daniel Hanford, Inc., Richland, Washington.

Kupfer, M. J., 1997p, Preliminary Tank Characterization Report for Single-Shell Tank 241-SX-102: Best-Basis Inventory, HNF-SD-WM-ER-661, Rev. 0, prepared by Lockheed Martin Hanford Corporation for Fluor Daniel Hanford, Inc., Richland, Washington.

Kupfer, M. J., 1997q, Preliminary Tank Characterization Report for Single-Shell Tank 241-SX-103: Best-Basis Inventory, HNF-SD-WM-ER-662, Rev. 0, prepared by Lockheed Martin Hanford Corporation for Fluor Daniel Hanford, Inc., Richland, Washington. 
Kupfer, M. J., 1997r, Preliminary Tank Characterization Report for Single-Shell Tank 241-SX-104: Best-Basis Inventory, HNF-SD-WM-ER-643, Rev. 0, prepared by Lockheed Martin Hanford Corporation for Fluor Daniel Hanford, Inc., Richland, Washington.

Kupfer, M. J., 1997s, Preliminary Tank Characterization Report for Single-Shell Tank 241-SX-105: Best-Basis Inventory, HNF-SD-WM-ER-644, Rev. 0, prepared by Lockheed Martin Hanford Corporation for Fluor Daniel Hanford, Inc., Richland, Washington.

Kupfer, M. J., 1997t, Preliminary Tank Characterization Report for Single-Shell Tank 241-SX-106: Best-Basis Inventory, HNF-SD-WM-ER-645, Rev. 0, prepared by Lockheed Martin Hanford Corporation for Fluor Daniel Hanford, Inc., Richland, Washington.

Kupfer, M. J., 1997u, Preliminary Tank Characterization Report for Single-Shell Tank 241-SX-107: Best-Basis Inventory, HNF-SD-WM-ER-671, Rev. 0, prepared by Lockheed Martin Hanford Corporation for Fluor Daniel Hanford, Inc., Richland, Washington.

Kupfer, M. J., 1997v, Preliminary Tank Characterization Report for Single-Shell Tank 241-SX-109: Best-Basis Inventory, HNF-SD-WM-ER-706, Rev. 0, prepared by Lockheed Martin Hanford Corporation for Fluor Daniel Hanford, Inc., Richland, Washington.

Kupfer, M. J., 1997w, Preliminary Tank Characterization Report for Single-Shell Tank 241-SX-110: Best-Basis Inventory, HNF-SD-WM-ER-681, Rev. 0, prepared by Lockheed Martin Hanford Corporation for Fluor Daniel Hanford, Inc., Richland, Washington.

Kupfer, M. J., 1997x, Preliminary Tank Characterization Report for Single-Shell Tank 241-SX-111: Best-Basis Inventory, HNF-SD-WM-ER-682, Rev. 0, prepared by Lockheed Martin Hanford Corporation for Fluor Daniel Hanford, Inc., Richland, Washington.

Kupfer, M. J., 1997y, Preliminary Tank Characterization Report for Single-Shell Tank 241-SX-112: Best-Basis Inventory, HNF-SD-WM-ER-683, Rev. 0, prepared by Lockheed Martin Hanford Corporation for Fluor Daniel Hanford, Inc., Richland, Washington.

Kupfer, M. J., 1997z, Preliminary Tank Characterization Report for Single-Shell Tank 241-SX-114: Best-Basis Inventory, HNF-SD-WM-ER-707, Rev. 0, prepared by Lockheed Martin Hanford Corporation for Fluor Daniel Hanford, Inc., Richland, Washington. 
Kupfer, M. J., 1997aa, Preliminary Tank Characterization Report for Single-Shell Tank 241-SX-115: Best-Basis Inventory, HNF-SD-WM-ER-684, Rev. 0, prepared by Lockheed Martin Hanford Corporation for Fluor Daniel Hanford, Inc., Richland, Washington.

Kupfer, M. J., 1997bb, Preliminary Tank Characterization Report for Single-Shell Tank 241-T-110: Best-Basis Inventory, HNF-SD-WM-ER-686, Rev. 0, prepared by Lockheed Martin Hanford Corporation for Fluor Daniel Hanford, Inc., Richland, Washington.

Kupfer, M. J., 1997cc, Preliminary Tank Characterization Report for Single-Shell Tank 241-T-201: Best-Basis Inventory, HNF-SD-WM-ER-726, Rev. 0, prepared by Lockheed Martin Hanford Corporation for Fluor Daniel Hanford, Inc., Richland, Washington.

Kupfer, M. J., 1997dd, Preliminary Tank Characterization Report for Single-Shell Tank "241-T-202: Best-Basis Inventory, HNF-SD-WM-ER-727, Rev. 0, prepared by Lockheed Martin Hanford Corporation for Fluor Daniel Hanford, Inc., Richland, Washington.

Kupfer, M. J., 1997ee, Preliminary Tank Characterization Report for Single-Shell Tank 241-T-203: Best-Basis Inventory, HNF-SD-WM-ER-728, Rev. 0, prepared by Lockheed Martin Hanford Corporation for Fluor Daniel Hanford, Inc., Richland, Washington.

Kupfer, M. J., 1997ff, Preliminary Tank Characterization Report for Single-Shell Tank 241-T-204: Best-Basis Inventory, HNF-SD-WM-ER-729, Rev. 0, prepared by Lockheed Martin Hanford Corporation for Fluor Daniel Hanford, Inc., Richland, Washington.

Kupfer, M. J., 1997gg, Preliminary Tank Characterization Report for Single-Shell Tank 241-TX-101: Best-Basis Inventory, HNF-SD-WM-ER-689, Rev. 0, prepared by Lockheed Martin Hanford Corporation for Fluor Daniel Hanford, Inc., Richland, Washington.

Kupfer, M. J., 1997hh, Preliminary Tank Characterization Report for Single-Shell Tank 241-TX-102: Best-Basis Inventory, HNF-SD-WM-ER-654, Rev. 0, prepared by Lockheed Martin Hanford Corporation for Fluor Daniel Hanford, Inc., Richland, Washington.

Kupfer, M. J., 1997ii, Preliminary Tank Characterization Report for Single-Shell Tank 241-TX-104: Best-Basis Inventory, HNF-SD-WM-ER-672, Rev. 0, prepared by Lockheed Martin Hanford Corporation for Fluor Daniel Hanford, Inc., Richland, Washington. 


\section{Tank Characterization Reports: Best-Basis Inventory}

Kupfer, M. J., 1997jj, Preliminary Tank Characterization Report for Single-Shell Tank 241-TX-105: Best-Basis Inventory, HNF-SD-WM-ER-655, Rev. 0, prepared by Lockheed Martin Hanford Corporation for Fluor Daniel Hanford, Inc., Richland, Washington.

Kupfer, M. J., '1997kk, Preliminary Tank Characterization Report for Single-Shell Tank 241-TX-106: Best-Basis Inventory, HNF-SD-WM-ER-656, Rev. 0, prepared by Lockheed Martin Hanford Corporation for Fluor Daniel Hanford, Inc., Richland, Washington.

Kupfer, M. J., 19971l, Preliminary Tank Characterization Report for Single-Shell Tank 241-TX-114: Best-Basis Inventory, HNF-SD-WM-ER-708, Rev. 0, prepared by Lockheed Martin Hanford Corporation for Fluor Daniel Hanford, Inc., Richland, Washington.

Kupfer, M. J., 1997mm, Preliminary Tank Characterization Report for Single-Shell Tank 241-TX-115: Best-Basis Inventory, HNF-SD-WM-ER-657, Rev. 0, prepared by Lockheed Martin Hanford Corporation for Fluor Daniel Hanford, Inc., Richland, Washington.

Kupfer, M. J., 1997nn, Preliminary Tank Characterization Report for Single-Shell Tank 241-TX-118: Best-Basis Inventory, HNF-SD-WM-ER-718, Rev. 0, prepared by Lockheed Martin Hanford Corporation for Fluor Daniel Hanford, Inc., Richland, Washington.

Kupfer, M. J., 1997oo, Preliminary Tank Characterization Report for Single-Shell Tank 241-TY-101: Best-Basis Inventory, HNF-SD-WM-ER-646, Rev. 0, prepared by Lockheed Martin Hanford Corporation for Fluor Daniel Hanford, Inc., Richland, Washington.

Kupfer, M. J., 1997pp, Preliminary Tank Characterization Report for Single-Shell Tank 241-TY-103: Best-Basis Inventory, HNF-SD-WM-ER-703, Rev. 0, prepared by Lockheed Martin Hanford Corporation for Fluor Daniel Hanford, Inc., Richland, Washington.

Kupfer, M. J., 1997qq, Preliminary Tank Characterization Report for Single-Shell Tank 241-TY-105: Best-Basis Inventory, HNF-SD-WM-ER-652, Rev. 0, prepared by Lockheed Martin Hanford Corporation for Fluor Daniel Hanford, Inc., Richland, Washington.

Kupfer, M. J., 1997rr, Preliminary Tank Characterization Report for Single-Shell Tank 241-U-101: Best-Basis Inventory, HNF-SD-WM-ER-732, Rev. 0, prepared by Lockheed Martin Hanford Corporation for Fluor Daniel Hanford, Inc., Richland, Washington. 
Kupfer, M. J., 1997ss, Preliminary Tank Characterization Report for Single-Shell Tank 241-U-103: Best-Basis Inventory, HNF-SD-WM-ER-712, Rev. 0, prepared by Lockheed Martin Hanford Corporation for Fluor Daniel Hanford, Inc., Richland, Washington.

Kupfer, M. J., 1997tt, Preliminary Tank Characterization Report for Single-Shell Tank 241-U-104: Best-Basis Inventory, HNF-SD-WM-ER-650, Rev. 0, prepared by Lockheed Martin Hanford Corporation for Fluor Daniel Hanford, Inc., Richland, Washington.

Kupfer, M. J., 1997uu, Preliminary Tank Characterization Report for Single-Shell Tank 241-U-111: Best-Basis Inventory, HNF-SD-WM-ER-713, Rev. 0, prepared by Lockheed Martin Hanford Corporation for Fluor Daniel Hanford, Inc., Richland, Washington.

Kupfer, M. J., 1997vv, Preliminary Tank Characterization Report for Single-Shell Tank 241-U-112: Best-Basis Inventory, HNF-SD-WM-ER-720, Rev. 0, prepared by Lockheed Martin Hanford Corporation for Fluor Daniel Hanford, Inc., Richland, Washington.

Lambert, S. L., 1997a, Preliminary Tank Characterization Report for Single-Shell Tank 241-C-102: Best-Basis Inventory, HNF-SD-WM-ER-651, Rev. 0, prepared by SGN Eurisys Services Corporation for Fluor Daniel Hanford, Inc., Richland, Washington.

Lambert, S. L., 1997b, Preliminary Tank Characterization Report for Single-Shell Tank 241-T-101: Best-Basis Inventory, HNF-SD-WM-ER-710, Rev. 0, prepared by SGN Eurisys Services Corporation for Fluor Daniel Hanford, Inc., Richland, Washington.

Lambert, S. L., 1997c, Preliminary Tank Characterization Report for Single-Shell Tank 241-T-103: Best-Basis Inventory, HNF-SD-WM-ER-725, Rev. 0, prepared by SGN Eurisys Services Corporation for Fluor Daniel Hanford, Inc., Richland, Washington.

Lambert, S. L. and D. W. Hendrickson, 1997a, Preliminary Tank Characterization Report for Single-Shell Tank 241-AX-103: Best-Basis Inventory, HNF-SD-WM-ER-686, Rev. 0, prepared by SGN Eurisys Services Corporation for Fluor Daniel Hanford, Inc., Richland, Washington.

Lambert, S. L. and D. W. Hendrickson, 1997b, Preliminary Tank Characterization Report for Single-Shell Tank 241-AX-104: Best-Basis Inventory, HNF-SD-WM-ER-675, Rev. 0, prepared by SGN Eurisys Services Corporation for Fluor Daniel Hanford, Inc., Richland, Washington. 


\section{HNF-1901 Rev 1}

\section{Tank Characterization Reports. Best Basis Inventory}

Lechelt, J. A., 1995, Tank Characterization Report for Single-Shell Tank 241-C-203, WHC-SD-WM-ER-478, Rev. 0, Westinghouse Hanford Company, Richland, Washington.

McCain, D. J., 1996a. Tank Characterization Report for Single-Shell Tank 241-B-106, WHC-SD-WM-ER-601, Rev. 0, Westinghouse Hanford Company, Richland, Washington.

McCain, D. J., 1996b, Tank Characterization Report for Single-Shell Tank 241-BX-112, WHC-SD-WM-ER-602, Rev. 0, Westinghouse Hanford Company, Richland, Washington.

McCain, D. J., 1997, Tank Characterization Report for Single-Shell Tank 241-BY-107, HNF-SD-WM-ER-637, Rev. 0, prepared by Lockheed Martin Hanford Corporation for Fluor Daniel Hanford, Inc., Richland, Washington.

Milliken, N. J., 1995a, Tank Characterization Report for Single-Shell Tank 241-BX-201, WHC-SD-WM-ER-408, Rev. 0, Westinghouse Hanford Company, Richland, Washington.

Milliken, N. J., 1995b, Tank Characterization Report for Single-Shell Tank 241-U-202, WHC-SD-WM-ER-484, Rev. 0, Westinghouse Hanford Company, Richland, Washington.

Place, D. E., 1997a, Preliminary Tank Characterization Report for Single-Shell Tank 241-TX-109: Best-Basis Inventory, HNF-SD-WM-ER-640, Rev. 0, prepared by SGN Eurisys Services Corporation for Fluor Daniel Hanford, Inc., Richland, Washington.

Place, D. E., 1997b, Preliminary Tank Characterization Report for Single-Shell Tank 241-TX-110: Best-Basis Inventory, HNF-SD-WM-ER-658, Rev. 0, prepared by SGN Eurisys Services Corporation for Fluor Daniel Hanford, Inc., Richland, Washington.

Place, D. E., 1997c, Preliminary Tank Characterization Report for Single-Shell Tank 241-TX-111: Best-Basis Inventory, HNF-SD-WM-ER-659, Rev. 0, prepared by SGN Eurisys Services Corporation for Fluor Daniel Hanford, Inc., Richland, Washington.

Place, D. E., 1997d, Preliminary Tank Characterization Report for Single-Shell Tank 241-TX-112: Best-Basis Inventory, HNF-SD-WM-ER-715, Rev. 0, prepared by SGN Eurisys Services Corporation for Fluor Daniel Hanford, Inc., Richland, Washington. 
Tank Characterization Reports: Best-Basis Inventory

Place, D. E., 1997e, Preliminary Tank Characterization Report for Single-Shell Tank 241-TX-113: Best-Basis Inventory, HNF-SD-WM-ER-716, Rev. 0, prepared by SGN Eurisys Services Corporation for Fluor Daniel Hanford, Inc., Richland, Washington.

Place, D. E., 1997f, Preliminary Tank Characterization Report for Single-Shell Tank 241-TX-116: Best-Basis Inventory, HNF-SD-WM-ER-705, Rev. 0, prepared by SGN Eurisys Services Corporation for Fluor Daniel Hanford, Inc., Richland, Washington.

Place, D. E., 1997g, Preliminary Tank Characterization Report for Single-Shell Tank 241-TX-117: Best-Basis Inventory, HNF-SD-WM-ER-711, Rev. 0, prepared by SGN Eurisys Services Corporation for Fluor Daniel Hanford, Inc., Richland, Washington.

Place, D. E., 1997h, Preliminary Tank Characterization Report for Single-Shell Tank 241-TY-102: Best-Basis Inventory, HNF-SD-WM-ER-719, Rev. 0, prepared by SGN Eurisys Services Corporation for Fluor Daniel Hanford, Inc., Richland, Washington.

Place, D. E, and D. W. Hendrickson, 1997, Preliminary Tank Characterization Report for Single-Shell Tank 241-AX-101: Best-Basis Inventory, HNF-SD-WM-ER-649, Rev. 0, prepared by SGN Eurisys Services Corporation for Fluor Daniel Hanford, Inc., Richland, Washington.

Raphael, G. F., 1995, Tank Characterization Report for Single-Shell Tank 241-U-204, WHC-SD-WM-ER-486, Rev. 0, Westinghouse Hanford Company, Richland, Washington.

Ryan, G. W., 1995a, Tank Characterization Report for Double-Shell Tank 241-AY-102, WHC-SD-WM-ER-454, Rev. 0, Westinghouse Hanford Company, Richland, Washington.

Ryan, G. W., 1995b, Tank Characterization Report for Double-Shell Tank 241-AZ-102, WHC-SD-WM-ER-411, Rev. 0, Westinghouse Hanford Company, Richland, Washington.

Ryan, G. W., 1995c, Tank Characterization Report for Single-Shell Tank 241-TY-104, WHC-SD-WM-ER-481, Rev. 0, Westinghouse Hanford Company, Richland, Washington.

Sasaki, L. M., 1996a, Tank Characterization Report for Single-Shell Tank 241-B-204, WHC-SD-WM-ER-581, Rev. 0, Westinghouse Hanford Company, Richland, Washington. 


\section{Tank Characterization Reports: Best-Basis Inventory}

Sasaki, L. M., 1996b, Tank Characterization Report for Single-Shell Tank 241-BX-106, WHC-SD-WM-ER-570, Rev. 0, Westinghouse Hanford Company, Richland, Washington.

Sasaki, L. M., 1996c, Tank Characterization Report for Single-Shell Tank 241-TX-107, WHC-SD-WM-ER-584, Rev. 0, Westinghouse Hanford Company, Richland, Washington.

Sasaki, L. M., 1997a, Tank Characterization Report for Double-Shell Tank 241-AW-105, HNF-SD-WM-ER-364, Rev. 1, prepared by Lockheed Martin Hanford Corporation for Fluor Daniel Hanford Inc., Richland, Washington.

Sasaki, L. M., 1997b, Tank Characterization Report for Single-Shell Tank 241-BY-102, HNF-SD-WM-ER-630, Rev. 0, prepared by Lockheed Martin Hanford Corporation for Fluor Daniel Hanford, Inc., Richland, Washington.

Sasaki, L. M., 1997c, Tank Characterization Report for Single-Shell Tank 241-T-107, HNF-SD-WM-ER-382, Rev. 1, prepared by Lockheed Martin Hanford Corporation for Fluor Daniel Hanford, Inc., Richland, Washington.

Schreiber, R. D., 1995a, Tank Characterization Report for Single-Shell Tank 241-C-201, WHC-SD-WM-ER-476, Rev. 0, Westinghouse Hanford Company, Richland, Washington.

Schreiber, R. D., 1995b, Tank Characterization Report for Single-Shell Tank 241-C-202, WHC-SD-WM-ER-477, Rev. 0, Westinghouse Hanford Company, Richland, Washington.

Schreiber, R. D., 1995c, Tank Characterization Report for Single-Shell Tank 241-U-201, WHC-SD-WM-ER-483, Rev. 0, Westinghouse Hanford Company, Richland, Washington.

Schreiber, R. D., 1995d, Tank Characterization Report for Single-Shell Tank 241-U-203, WHC-SD-WM-ER-485, Rev. 0, Westinghouse Hanford Company, Richland, Washington.

Schreiber, R. D., 1996a, Tank Characterization Report for Single-Shell Tank 241-B-101, WHC-SD-WM-ER-528, Rev. 0, Westinghouse Hanford Company, Richland, Washington.

Schreiber, R. D., 1996b, Tank Characterization Report for Single-Shell Tank 241-BX-110, WHC-SD-ER-566, Rev. 0, Westinghouse Hanford Company, Richland, Washington. 


\section{Tank Characterization Reports: Best-Basis Inventory}

Schreiber, R. D., 1996c, Tank Characterization Report for Single-Shell Tank 241-BY-110, WHC-SD-WM-ER-591, Rev. 0, Westinghouse Hanford Company, Richland, Washington.

Schreiber, R. D., 1996d, Tank Characterization Report for Single-Shell Tank 241-C-106, WHC-SD-WM-ER-645, Rev. 0, Westinghouse Hanford Company, Richland, Washington.

Schreiber, R. D., 1997, Tank Characterization Report for Single-Shell Tank 241-B-108, HNF-SD-WM-ER-674, Rev. 0, prepared by Lockheed Martin Hanford Corporation for Fluor Daniel Hanford, Inc., Richland, Washington.

Sederburg, J. P., 1995a, Tank Characterization Report for Single-Shell Tank 241-AX-102, WHC-SD-WM-ER-472, Rev. 0, Westinghouse Hanford Company, Richland, Washington.

Sederburg, J. P., 1995b, Tank Characterization Report for Single-Shell Tank 241-BX-108, WHC-SD-WM-ER-407, Rev. 0, Westinghouse Hanford Company, Richland, Washington.

Sederburg, J. P., 1995c, Tank Characterization Report for Single-Shell Tank 241-C-108, WHC-SD-WM-ER-503, Rev. 0, Westinghouse Hanford Company, Richland, Washington.

Simpson, B. C., 1995, Tank Characterization Report for Single-Shell Tank 241-C-111, WHC-SD-WM-ER-475, Rev. 0, Westinghouse Hanford Company, Richland, Washington.

Simpson, B. C., 1996, Tank Characterization Report for Single-Shell Tank 241-S-107, WHC-SD-WM-ER-589, Rev. 0, Westinghouse Hanford Company, Richland, Washington.

Simpson, B. C., 1997a, Tank Characterization Report for Single-Shell Tank 241-C-109, HNF-SD-WM-ER-402, Rev. 1, prepared by Lockheed Martin Hanford Corporation for Fluor Daniel Hanford, Inc., Richland, Washington.

Simpson, B. C., 1997b, Tank Characterization Report for Single-Shell Tank 241-C-112, HNF-SD-WM-ER-541, Rev. 1, prepared by Lockheed Martin Hanford Corporation for Fluor Daniel Hanford, Inc., Richland, Washington.

Thompson, R. R., 1996, Tank Characterization Report for Double-Shell Tank 241-AY-101, WHC-SD-WM-ER-605, Rev. 0, Westinghouse Hanford Company, Richland, Washington. 


\section{HNF-1901 Rev 1}

\section{Tank Characterization Reports: Best-Basis Inventory}

Thompson, R. R., 1997, Tank Characterization Report for Double-Shell Tank 241-AP-106, HNF-SD-WM-ER-361, Rev. 1, prepared by Lockheed Martin Hanford Corporation for Fluor Daniel Hanford Inc., Richland, Washington.

Tusler, L. A., 1995a, Tank Characterization Report for Double-Shell Tank 24I-AW-104, WHC-SD-WM-ER-453, Rev. 0, Westinghouse Hanford Company, Richland, Washington.

Tusler, L. A., 1995b, Tank Characterization Report for Single-Shell Tank 241-C-105, WHC-SD-WM-ER-489, Rev. 0, Westinghouse Hanford Company, Richland, Washington.

Wilkins, N. E., 1997, Tank Characterization Report for Double-Shell Tank 241-AN-103, HNF-SD-WM-ER-702, Rev. 0, prepared by Lockheed Martin Hanford Corporation for Fluor Daniel Hanford Inc., Richland, Washington.

Winkleman, W. D., 1996, Tank Characterization Report for Double-Shell Tank 241-AP-104, WHC-SD-WM-ER-596, Rev. 0, Westinghouse Hanford Company, Richland, Washington.

Winkleman, W. D., 1997, Tank Characterization Report for Single-Shell Tank 241-BX-107, HNF-SD-WM-ER-539, Rev. 1, prepared by Lockheed Martin Hanford Corporation for Fluor Daniel Hanford, Inc., Richland, Washington.

Winters, W. I., 1995, Tank Characterization Report for Double-Shell Tank 241-SY-102, WHC-SD-WM-ER-366, Rev. 0, Westinghouse Hanford Company, Richland, Washington.

Winters, W. I., 1996, Tank Characterization Report for Single-Shell Tank 241-C-103, WHC-SD-WM-ER-558, Rev. 0, Westinghouse Hanford Company, Richland, Washington.

Winters, W. I., 1997, Tank Characterization Report for Single-Shell Tank 241-B-102, WHC-SD-WM-ER-405, Rev. 0, Westinghouse Hanford Company, Richland, Washington.

\section{Documents}

Acquire H., Jr, 1995, 242-A Evaporator/Crystallizer Final Safety Analysis Report, WHC-SD-WM-SAR-023, Rev. 2, Westinghouse Hanford Company, Richland, Washington. 


\section{Documents}

Acree, C. D., 1998, Tank Waste Remediation System Mission Analysis Report, HNF-SD-WM-MAR-008, Rev. 3, prepared by Lockheed Martin Hanford Corporation for Fluor Daniel Hanford, Inc., Richland, Washington.

Allen, M. , 1999, River Protection Project Environmental Program Plan, HNF-1773, Rev. 2, prepared by Lockheed Martin Hanford Corporation for Fluor Daniel Hanford, Inc., Richland, Washington.

Alm, A. L., 1996, Approval of Critical Decisions for Phase I Immobilized High-Level and Low-Activity Waste Interim Storage and Tank Farm Restoration and Safe Operations Projects (Projects W-464, W-465, and W-314), (letter to J. Wagoner, Manager, U.S. Department of Energy, Richland Operations Office, Richland, Washington, December 26), U.S. Department of Energy, Washington, D.C.

Bailey, J. W., 1997, Functional Design Criteria for Tank 241-C-106 Waste Retrieval, Project W-320, HNF-SD-W320-FDC-001, Rev. 4, prepared by Numatec Hanford Corporation for Fluor Daniel Hanford, Inc., Richland, Washington.

Bailey, J. W., 1998a, Project W-320, 241-C-106 Sluicing, Master Calculation List, HNF-2527, Rev. 0, prepared by Numatec Hanford Corporation for Fluor Daniel Hanford, Inc., Richland, Washington.

Bailey, J. W., 1998b, Project W-320, 241-C-106 Waste Retrieval Spare Parts List, HNF-2404, Rev. 1, prepared by Numatec Hanford Corporation for Fluor Daniel Hanford, Inc., Richland, Washington.

Bailey, J. W., and R. R. Bevins, 1997, Preliminary Engineering Analysis for Safety Class and Safety Significant WRSS Equipment, HNF-1559, prepared by Numatec Hanford Corporation for Fluor Daniel Hanford, Inc., Richland, Washington.

Barcot, R. A., 1999, Solid Waste Integrated Forecast Technical (SWIFT) Report FY 2000 to FY 2046, HNF-EP-0918, Rev. 6, prepared by Waste Management Federal Services of Hanford, Inc., for Fluor Daniel Hanford, Inc., Richland, Washington.

Bauer, J. D., 1994a, Notice of Construction Application Pursuant to Washington Administrative Code 246-247 for Ventilation Upgrades, 241-AY and 241-AZ Tank Farms, (Correspondence 9400852 to A. W. Conklin, Washington Department of Health, March 2), U.S. Department of Energy, Richland Operations Office, Richland, Washington.

Bauer, J. D., 1994b, Notice of Construction Application Pursuant to Washington Administrative Code 173-460 for Ventilation Upgrades, 241-AY and 241-AZ Tank Farms, (Correspondence 9400853 to J. Stohr, Washington Department of Ecology, March 2), U.S. Department of Energy, Richland Operations Office, Richland, Washington. 


\section{Documents}

Bell, M. L., 1994, TWRS Minimum/Maximum Laboratory Capacity Strategy, (internal memorandum 12000-94-005 to C. DeFigh-Price, February 28), Westinghouse Hanford Company, Richland, Washington.

Bellomy; J. R., 1995, Project W-320 Tank 241-C-106 Waste Retrieval Sluicing System Testing Plan, WHC-SD-W320-TP-001, Rev. 0, Westinghouse Hanford Company, Richland, Washington.

Bevins, R. R., 1997, Severe Environmental Qualifications and Life Expectancy of Immersible Pump System, HNF-SD-W320-ER-005, prepared by Numatec Hanford Corporation for Fluor Daniel Hanford, Inc., Richland, Washington.

Biebesheimer, E., 1996, High-Level Waste Storage Tank Farms/242-A Evaporator Standards/Requirements Identification Document, WHC-SD-MP-SRID-001, Rev. 1, Westinghouse Hanford Company, Richland, Washington.

BNFL, 1998a, Interface Control Document Between DOE and BNFL Inc. for Raw Water, BNFL-5193-ID-01, Rev. 3, DRAFT, BNFL Inc., Richland, Washington.

BNFL, 1998b, Interface Control Document Between DOE and BNFL Inc. for Potable Water, BNFL-5193-ID-02, Rev. 3, DRAFT, BNFL Inc., Richland, Washington.

BNFL, 1998c, Interface Control Document Between DOE and BNFL Inc. for Radioactive Solid Waste, BNFL-5193-ID-03, Rev. 3, DRAFT, BNFL Inc., Richland, Washington.

BNFL, 1998d, Interface Control Document Between DOE and BNFL Inc. for Non-Radioactive, Non-Dangerous Liquid Effluents, BNFL-5193-ID-05, Rev. 3, DRAFT, BNFL Inc., Richland, Washington.

BNFL, 1998e, Interface Control Document Between DOE and BNFL Inc. for Radioactive, Dangerous Liquid Effluents, BNFL-5193-ID-06, Rev. 3, DRAFT, BNFL Inc., Richland, Washington.

BNFL, 1998f, Interface Control Document Between DOE and BNFL Inc. for Land for Siting, BNFL-5193-ID-09, Rev. 3, Draft, BNFL Inc., Richland, Washington.

BNFL, 1998g, Interface Control Document Between DOE and BNFL Inc. for Deactivated Facility and Site, BNFL-5193-ID-10, Rev. 3, Draft, BNFL Inc., Richland, Washington.

BNFL, 1998h, Interface Control Document Between DOE and BNFL Inc. for Electricity, BNFL-5193-ID-11, Rev. 3, Draft, BNFL Inc., Richland, Washington.

BNFL, 1998i, Interface Control Document Between DOE and BNFL Inc. for Roads and Rails, BNFL-5193-ID-12, Rev. 3, Draft, BNFL Inc., Richland, Washington. 


\section{Documents}

BNFL, 1998j, Interface Control Document Between DOE and BNFL Inc. for Immobilized High-Level Waste Product, BNFL-5193-ID-14, Rev. 3, Draft, BNFL Inc., Richland, Washington.

BNFL, 1998k, Interface Control Document Between DOE and BNFL Inc. for Immobilized Low-Activity Waste Product, BNFL-5193-ID-15, Rev. 3, Draft, BNFL Inc., Richland, Washington.

BNFL, 19981, Interface Control Document Between DOE and BNFL Inc. for Entrained Solids, BNFL-5193-ID-16, Rev. 3, Draft, BNFL Inc., Richland, Washington.

BNFL, 1998m, Interface Control Document Between DOE and BNFL Inc. for Low-Activity Waste Feed, BNFL-5193-ID-19, Rev. 3, Draft, BNFL Inc., Richland, Washington.

BNFL, 1998n, Interface Control Document Between DOE and BNFL Inc. for High-Level Waste Feed, BNFL-5193-ID-20, Rev. 3, Draft, BNFL Inc., Richland, Washington.

BNFL, 1998o, Interface Control Document Between DOE and BNFL Inc. for Air Emisions, BNFL-5193-ID-22, Rev. 3, Draft, BNFL Inc., Richland, Washington.

BNFL, 1998p, Interface Control Document Between DOE and BNFL Inc. for Waste Treatability Samples, BNFL-5193-ID-23, Rev. 3, Draft, BNFL Inc., Richland, Washington.

BNFL, 1998q, Interface Control Document Between DOE and BNFL Inc. for Emergency Response, BNFL-5193-ID-25, Rev. 3, Draft, BNFL Inc., Richland, Washington.

BNFL, 1998r, Interface Control Document Between DOE and BNFL Inc. for Permits, BNFL-5193-ID-26, Rev. 3, Draft, BNFL Inc., Richland, Washington.

Boes, K. A., 1996a, Conceptual Design Report for Tank Farm Restoration and Safe Operations, Project W-314, WHC-SD-W314-CDR-001, Rev. 1, Westinghouse Hanford Company, Richland, Washington.

Boes, K. A., 1996b, Preliminary Design Requirements Document for Project W-314, Tank Farm Restoration and Safe Operations, WHC-SD-W314-DRD-001, Rev. 1, Westinghouse Hanford Company, Richland, Washington.

Bourger, F. H., 1994, Hazard Categorization Report for the 200 Area Effluent Treatment Facility, WHC-SD-C018H-HC-002, Rev. 0, Westinghouse Hanford Company, Richland, Washington.

Bourger, F. H., and J. C. Conner, 1992, Preliminary Safety Analysis Report for Project W151, Tank 241-AZ-101 Waste Retrieval System, WHC-SD-W151-PSAR-001, Rev. 0, Westinghouse Hanford Company, Richland, Washington. Also listed under J.C. Sabin, who cleared this document 12/21/93. 


\section{Documents}

Brantley, W. M., 1996, Functional Design Criteria for Project W-058, Replacement of the Cross-Site Transfer System, WHC-SD-W058-FDC-001, Rev. 4, Westinghouse Hanford Company, Richland, Washington.

Burbank, D. A., 1996, Alternatives Generation and Analysis Report for Immobilized Low-Level Waste Interim Storage Architecture, WHC-SD-W465-AGA-001, Rev. 0, Westinghouse Hanford Company, Richland, Washington.

Burbank, D.A., 1997, Design Requirements Document for Project W-465, Immobilized Low-Activity Waste Interim Storage, HNF-SD-W465-DRD-001, Rev. 0., prepared by SGN Eurisys Services Corporation for Fluor Daniel Hanford, Inc., Richland, Washington.

Burbank, D. A., 1999, River Protection Project Immobilized Low-Activity Waste Disposal Plan, HNF-1517, Rev. 1, prepared by Lockheed Martin Hanford Corporation for Fluor Daniel Hanford, Inc., Richland, Washington.

Burbank, D. A. and T. M. Hohl, 1999, Reanalysis of Alternatives for Immobilized Low-Activity Waste Disposal, HNF-4003, Rev. 0, prepared by COGEMA Engineering Corporation for Fluor Daniel Hanford, Inc., Richland, Washington.

Burbank, D. A. and M. J. Klem, 1997, Analysis of Alternatives for Immobilized Low-Activity Waste Disposal, HNF-SD-TWR-AGA-004, Rev. 0, prepared by SGN Eurisys Services Corporation for Fluor Daniel Hanford, Inc., Richland, Washington.

Burgard, K. C., 1998, Conceptual Design Report for immobilized High-Level Waste Interim Storage Facility Project, HNF-2298, Rev. 1, Fluor Daniel Hanford, Inc., Richland, Washington.

Calmus, R. B., 1996a, Design Requirements Document for Interim Storage Phase I Solidification of High-Level Waste, WHC-SD-WM-DRD-012, Rev. 0, Westinghouse Hanford Company, Richland, Washington.

Calmus, R. B., 1996b, High-Level Waste Interim Storage Architecture Selection - Decision Report, WHC-SD-WM-TA-183, Rev. 0, Westinghouse Hanford Company, Richland, Washington.

Calmus, R. B., 1999a, Immobilized High-Level Waste Interim Storage Alternatives Generation and Analysis Decision Report, HNF-3899, Rev. 0, prepared by Lockheed Martin Hanford Corporation for Fluor Daniel Hanford, Inc., Richland, Washington.

Calmus, R. B., 1999b, River Protection Project Immobilized High-Level Waste Interim Storage Plan, HNF-1751, Rev. 1, prepared by Lockheed Martin Hanford Corporation for Fluor Daniel Hanford, Inc., Richland, Washington. 


\section{WW}

Carothers, K. G., S. D. Estey, N. W. Kirch, L. A., and J. W. Bailey 1998, Tank 241-C-106 Waste Retrieval Sluicing System Process Control Plan, HNF-SD-WM-PCP-013, Rev. 1, prepared by Lockheed Martin Hanford Corporation for Fluor Daniel Hanford, Inc., Richland, Washington.

Castleberry, J. L., 1997, Spare Parts List W-030 Tank Farm Ventilation Upgrade, HNF-1759, Rev. 0, prepared by Lockheed Martin Hanford Corporation for Fluor Daniel Hanford, Inc., Richland, Washington.

Claghorn, R. D., 1997, Decision Document for the Final Disposition of Cesium and Strontium Capsules, HNF-SD-WM-RPT-294, Rev. 0, prepared by Numatec Hanford Corporation for Fluor Daniel Hanford, Inc., Richland, Washington.

Clifton, F. T., 1994, Project W030 Final Review Report, WHC-SD-W030-DRR-005, Rev. 0, Westinghouse Hanford Company, Richland, Washington.

Clifton, F. T., 1995a, Acceptance Test Procedure for Cathodic Protection, Rectifier 11, WHC-SD-W030-ATP-003, Rev. 0, Westinghouse Hanford Company, Richland, Washington.

Clifton; F. T., 1995b, Acceptance Test Procedure for Cathodic Protection, Rectifier 31, WHC-SD-W030-ATP-001, Rev. 0, Westinghouse Hanford Company, Richland, Washington.

Clifton, F: T., 1995c, Acceptance Test Procedure for Cathodic Protection, Rectifier 4l, WHC-SD-W030-ATP-002, Revi. 0, Westinghouse Hanford Company, Richland, Washington.

Clifton, F. T., 1996a, Acceptance Test Procedure - Tank Farm and Miscellaneous Instrumentation, WHC-SD-W030-ATP-004, Rev. 0, Westinghouse Hanford Company, Richland, Washington.

Clifton, F. T., 1996b, Acceptance Test Procedure - Tank Farm Ventilation Upgrade W030; Primary Vent Filter Train, WHC-SD-W030-ATP-006, Rev. 0, Westinghouse Hanford Company, Richland, Washington.

Colosi, K. A., 1995, Acceptance Test Procedure Backup Power System, WHC-SD-W030-ATP-007, Rev. 0, Westinghouse Hanford Company, Richland, Washington.

Crane, A. F., 1997, 200 Area Treated Effluent Disposal Facility Interface Control, HNF-SD-W049H-ICD-001, Rev. 4, prepared by Rust Federal Services Hanford, Inc. for Fluor Daniel Hanford, Inc., Richland, Washington. 
HNF-1901 Rev 1

\section{Documents}

Crass, D. W., 1996a, W-151 Steam Coil Fatigue Analysis for Mixer Pump Jet Loads, WHC-SD-W151-DA-006, Rev. 0, Westinghouse Hanford Company, Richland, Washington.

Crass, D. W., 1996b, W-151 Transfer Pump Stress Analysis for Mixer Pump Jet Loads, WHC-SD-W151-DA-007, Rev. 0, Westinghouse Hanford Company, Richland, Washington.

Crass, D. W., 1997, Formal Design Review Report Project W-151 Mixer Pump Procurement, HNF-SD-W151-DRR-002, Rev. 0, prepared by Lockheed Martin Hanford Corporation for Fluor Daniel Hanford, Inc., Richland, Washington.

Dallas, M. D., 1997, FY 1998 Annual Work Plan for Infrastructure Programs WBS 6./7, HNF-SP-1169-98, Rev. 0, prepared by DynCorp Tri-Cities Services, Inc. for Fluor Daniel Hanford, Inc., Richland, Washington.

Deffenbaugh, M. L., 1996, Environmental Requirements Checklist for the High-Level Waste Storage Project Canister Storage Building, (correspondence 70100-96-004 to K. C. Burgard, November 4), Lockheed Martin Hanford Corporation, Richland, Washington.

Deffenbaugh, M. L., 1998, Permitting. Plan for the High-Level Waste Interim Storage Project W-464, HNF-SD-ENV-EE-002, Rev. 1, prepared by Lockheed Martin Hanford Corporation for Fluor Daniel Hanford, Inc., Richland, Washington.

Deffenbaugh, M. L., J. D. Guberski, C. J. Grando, V. L. Armstrong, J. E. Mercado, and M. W. Cline, 1997, Permitting Plan for the Immobilized Low-Activity Waste Project, HNF-SD-ENV-EE-003, Rev. 0, prepared by Lockheed Martin Hanford Corporation for Fluor Daniel Hanford, Inc., Richland Washington.

Dexter, M. L., 1999, RPP Environmental Permits and Related Documentation, HNF-4474, Rev. 1, prepared by Lockheed Martin Hanford Corporation for Fluor Daniel Hanford, Inc., Richland, Washington.

DOE, 1996a, Draft Hanford Remedial Action Environmental Impact Statement and Comprehensive Land Use Plan, DOE/EIS-0222D, U.S. Department of Energy, Washington, D.C.

DOE, 1996b, Waste Acceptance - Systems Requirements Document, DOE/RW-0351P, Rev. 2 , U.S. Department of Energy, Washington, D.C.

DOE and Ecology, 1996, Tank Waste Remediation System, Hanford Site, Richland, Washington, Final Environmental Impact Statement, DOE/EIS-0189, U.S. Department of Energy and Washington State Department of Ecology, Washington, D.C. 


\section{HNF-1901 Rev 1}

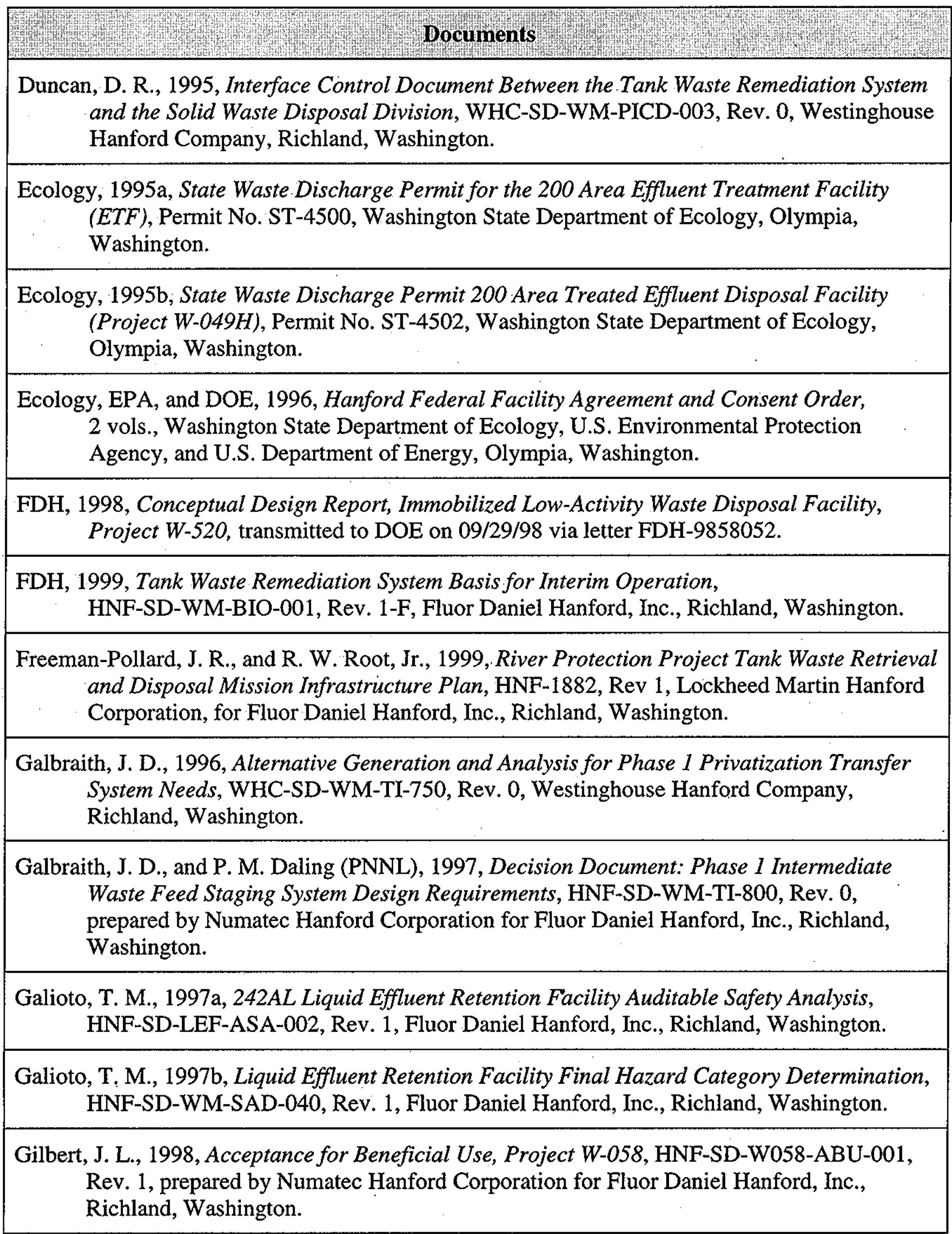


HNF-1901 Rev 1

\section{Documents}

Greager, T. M., 1996, Interface Control Document Between Analytical Services and Solid Waste Disposal Division, WHC-SD-WM-PICD-005, Rev. 1, Westinghouse Hanford Company, Richland, Washington.

Grenard, C. E., and R. D. Claghorn, T. J. Conrads, and M. A. deLamare, 1999, System - Specification for the Double-Shell Tank System, HNF-SD-WM-TRD-007, Rev. 0, prepared by COGEMA Engineering Corporation for Fluor Daniel Hanford, Inc., Richland, Washington.

Guimond, R. J., and T. J. O'Toole, 1996, Revised Interim Policy on Regulatory Structure for Low-Level Radioactive Waste Management and Disposal, (memorandum to U.S. Department of Energy, Department EM-30, July 31), U.S. Public Health Service, Washington, D.C.

Hanson, C. A., 1996, Memorandum of Agreement (MOA) - Utilization of Canister Storage Building (CSB) Vaults 2 and 3 for Immobilized High-Level Tank Waste, (memorandum 96-SFD-104 to Jackson Kinzer, Assistant Manager, Office of Tank Waste Remediation System, April 18), U.S. Department of Energy, Richland Operations Office, Richland, Washington.

Hammers, J. S., 1999a, Project W-314 Specific Test and Evaluation Plan 241-AN-A Valve Pit, HNF-1733, Rev. 4A, prepared by Numatec Hanford Corporation for Fluor Daniel Hanford, Inc., Richland, Washington.

Hammers, J. S., 1999b, Test and Evaluation Plan for Project W-314 Tank Farm Restoration and Safe Operation, HNF-SD-W314-TEP-001, Rev. 3, prepared by Numatec Hanford Corporation for Fluor Daniel Hanford, Inc., Richland, Washington.

Hill, L. F., 1995, Acceptance Test Procedure for W030 Monitor and Control System Software, WHC-SD-W030-ATP-0011, Rev. 0, Westinghouse Hanford Company, Richland, Washington.

Howell, T. G., 1997, Project W-058 Startup Test Plan, HNF-SD-W058-SUP-002, Rev. 0, Numatec Hanford Corporation for Fluor Daniel Hanford, Inc., Richland, Washington.

Huckfeldt, R. A., 1999, Tank Farm Health and Safety Plan, HNF-SD-WM-HSP-002, Rev 3A, Lockheed Martin Hanford Corporation for Fluor Daniel Hanford, Inc., Richland, Washington.

Jacobs, E. R., 1996, Final CSB High-Level Waste Supplemental Report, (letter FRF049 to J. J. Jones, Westinghouse Hanford Company, September 19), Fluor Daniel, Inc., Irvine, California. 
HNF-1901 Rev 1

\section{Documents}

Jacobson, R. W., 1997, Alternative Generation and Analysis Report, Tank Farm Monitoring and Master Pump Shutdown, Tank Farm Restoration and Safe Operation, W-314, HNF-SD-W314-AGA-007, Rev. 0, prepared by Lockheed Martin Hanford Corporation for Fluor Daniel Hanford, Inc., Richland, Washington.

Jensen, C. E., 1998, TWRS Facility Safety Equipment List, HNF-SD-WM-SEL-040, Rev. 1, prepared by Lockheed Martin Hanford Corporation for Fluor Daniel Hanford, Inc., Richland, Washington.

Joyce, S. M., 1997, Hanford Analytical Sample Projections FY 1996 - FY 2001, HNF-SD-WM-TI-608, Rev. 4, prepared by Waste Management Federal Service of Hanford for Fluor Daniel Hanford, Inc., Richland Washington.

Julyk, L. J., 1997, Evaluation of the Effect of Project W-151 Mixer Pump Jets on In-Tank Equipment Considering Potential Sludge Buildup on Equipment in Waste Tank 241-AZ-101, HNF-SD-W151-DA-008, Rev. 0, prepared by Fluor Daniel Northwest for Fluor Daniel Hanford, Inc., Richland, Washington.

Keller, C. M., 1997, Functional Design Criteria for the Tank Farm Ventilation Upgrade, Project W-030, HNF-SD-600-FDC-001, Rev. 4, prepared by Fluor Daniel Northwest for Fluor Daniel Hanford, Inc., Richland, Washington.

Kidder, R. J., 1996, Replacement of the Cross-Site Transfer System Preliminary Safety Analysis Report, WHC-SD-W.058-PSAR-001, Rev.1, Westinghouse Hanford Company, Richland, Washington.

Kirkbride, R. A., G. K. Allen, P. J. Certa, G. T. MacLean, A. F. Manuel, R. M. Orme, D. L. Penwell, L. W. Shelton, E. J. Slaathaug, and R. S. Wittman, 1999, Tank Waste Remediation System Operation and Utilization Plan to Support Waste Feed Delivery, HNF-SD-WM-SP-012, Rev. 1, Volumes I and II, prepared by Numatec Hanford Corporation and COGEMA Engineering Corporation for Fluor Daniel Hanford, Inc., Richland, Washington.

Kohlman, E. H., 1993, Project W-151 Supplemental Design Requirements, WHC-SD-W151-SDRD-001, Rev. 0, Westinghouse Hanford Company, Richland, Washington.

Kupfer, M. J., A. L. Boldt, B. A. Higley, K. M. Hodgson, L. W. Shelton, B. C. Simpson, R. A. Watrous, S. L. Lambert, D. E. Place, R. M. Orme, G. L. Borsheim, N. G. Colton, M. D. LeClair, R. T. Winward, and W. W. Schulz, 1999, Standard Inventories of Chemicals and Radionuclides in Hanford Site Tank Wastes, HNF-SD-WM-TI-740, Rev. 0-C, prepared by Lockheed Martin Hanford Corporation for Fluor Daniel Hanford, Inc., Richland, Washington. 
HNF-1901 Rev 1

\section{Documents}

LaBarge, M. J., 1992, Engineering Study 222-S High-level Drain System Upgrade Project W-057, WHC-SD-W057-ES-001, Rev. 0, Westinghouse Hanford Company, Richland, Washington.

Lambert, D. L., 1990, Tank 101-AZ Waste Retrieval System Project W-151, WHC-SD-W151-CDR-001, Rev. 0, Westinghouse Hanford Company, Richland, Washington.

Lavender, J. C., 1992, 242-A Evaporator/Crystallizer Safety Analysis Report, WHC-SD-WMSAR-023, Rev. 1, Westinghouse Hanford Company, Richland, Washington.

Le, E. Q., 1998, 200 Area Effluent Treatment Facility Auditable Safety Analysis Report, HNFSD-ETF-ASA-001, Rev. 3A, Waste Management Federal Services of Hanford for Fluor Daniel Hanford, Inc., Richland, Washington.

Lenseigne, D. L., 1998, Tank Waste Remediation System Fiscal Year 1999 Multi-Year Work Plan WBS 1.1, HNF-SP-1230, Rev. 1, prepared by Lockheed Martin Hanford Corporation for Fluor Daniel Hanford, Inc., Richland, Washington.

Lindsey, D. W. 1997, Liquid Effluent Retention Facility/Effluent Treatment Facility Treatability Envelope, Correspondence No. WMH-9758688, prepared by Waste Management Federal Services of Hanford for Fluor Daniel Hanford, Inc., Richland, Washington.

LMHC, 1999a, Agreement in Principle Between Lockheed Martin Hanford Corporation and DynCorp Tri-Cities Services, Inc., Updated for Fiscal Year 2000, Lockheed Martin Hanford Corporation, Richland, Washington.

LMHC, 1999b, Agreement in Principle Between Lockheed Martin Hanford Corporation and Waste Management Federal Services of Hanford, Inc., Updated for Fiscal Year 2000, Lockheed Martin Hanford Corporation, Richland, Washington.

LMHC, 1999c, RPP Administration, HNF-IP-0842, prepared by Lockheed Martin Hanford Corporation for Fluor Daniel Hanford Inc., Richland, Washington.

LMHC, 1999d, Tank Waste Remediation System Technical Safety Requirements, HNF-SD-WMTSR-006, Rev. 0-U, prepared by Lockheed Martin Hanford Corporation for Fluor Daniel Hanford, Inc., Richland, Washington.

Mann, F. M., C. R. Eiholzer, A. H. Lu, P. D. Rittman, G. F. Williamson, N. W. Kline, Y. Chen, B. P. McGrail, and N. R. Brown, 1997, Hanford Low-Level Tank Waste Interim Performance Assessment, HNF-EP-0884, Rev. 1, Fluor Daniel Hanford, Inc., Richland, Washington. 


\section{Documents}

Mattichak, R. W., 1996a, Conceptual Design Letter Report for Project W-454, AW Jumper Manifold Upgrade, WHC-SD-W454-CDR-001, Rev. 0, Westinghouse Hanford Company, Richland, Washington.

Mattichak, R. W., 1996b, Functional Design Criteria for AW Jumper Manifold Upgrade 241-AW Tank Farm Project W-454, WHC-SD-W454-FDC-001, Rev. 1, Westinghouse Hanford Company, Richland, Washington.

McVey, C. B., 1991, Environmental Hot Cell Expansion Project W-041, WHC-SD-W041-FDC-001, Rev. 2, Westinghouse Hanford Company, Richland, Washington.

McVey, C. B., 1992, Environmental Hot Cell Expansion - Project W-041, WHC-SD-WM-ES-107, Rev. 0, Westinghouse Hanford Company, Richland, Washington.

Moody, D. A., 1996, 241-AZ-101 Mixer Pump Support Assembly Extension Riser, and Spray Wash System Design Verification, WHC-SD-W151-DA-005, Rev. 0, Westinghouse Hanford Company, Richland, Washington.

Mouette, P., 1997, Preliminary Safety Evaluation for Project W-465, Immobilized Low-Activity Waste Interim Storage, HNF-SD-W465-PSE-001, Rev. 0, prepared by Numatec Hanford Corporation for Fluor Daniel Hanford, Inc., Richland, Washington.

NHC, 1998, Design Basis Document, Project W-320, Tank 241-C-106, Sluicing Project Rebaselining Change Request New Scope, HNF-SD-W320-DB-001, Rev. 2, prepared by Numatec Hanford Corporation for Fluor Daniel Hanford, Inc., Richland, Washington.

NHC, 1999a, Level 2 Specification for the Double-Shell Tank Utility System, (December) HNF-4157, Rev. 0, prepared by Numatec Hanford Corporation for Fluor Daniel Hanford, Inc., Richland, Washington.

NHC, 1999b, Level 2 Specification for the Double-Shell Tank Ventilation System, (October) HNF-5196, Rev. 0, prepared by Numatec Hanford Corporation for Fluor Daniel Hanford, Inc., Richland, Washington.

NHC, 1999c, Level 2 Specification for the Double-Shell Tank Transfer Valving System, HNF-4160, Rev. 0, prepared by Numatec Hanford Corporation for Fluor Daniel Hanford, Inc., Richland, Washington.

NHC, 1999d, Level 2 Specification for the Double-Shell Tank Transfer Piping System, HNF-4161, Rev. 0, prepared by Numatec Hanford Corporation for Fluor Daniel Hanford, Inc., Richland, Washington. 


\section{Documents}

NHC, 1999e, Level 2 Specification for the Double-Shell Tank Transfer Pump System, HNF-4162,

Rev. 0, prepared by Numatec Hanford Corporation for Fluor Daniel Hanford, Inc.,

Richland, Washington.

NHC, 1999f, Level 2 Specification for the Double-Shell Tank Caustic and Diluent Transfer System, (November) HNF-4163, Rev. 0, prepared by Numatec Hanford Corporation for Fluor Daniel Hanford, Inc., Richland, Washington.

NHC, 1999g, Level 2 Specification for the Double-Shell Tank Mixer Pump System, (October) HNF-4164, Rev. 0, prepared by Numatec Hanford Corporation for Fluor Daniel Hanford, Inc., Richland, Washington.

Nordquist, E. M., 1989, Conceptual Design Report, Tank Farm Ventilation Upgrade Cathodic Protection System, WHC-SD-W030-CDR-001, Rev. 0, Westinghouse Hanford Company, Richland, Washington. Available in Project File only.

Nordquist, E. M., 1995, Mixer Pump Test Specification Project W-151, WHC-SD-W151-TS-001, Rev. 0, Westinghouse Hanford Company, Richland, Washington.

Nordquist, E. M., 1996, Project W-151 Test Plan, WHC-SD-W151-TP-003, Rev. 0, Westinghouse Hanford Company, Richland, Washington.

Nordquist, E. M., 1997a, Document Required for Acceptance for Beneficial Use of Project W-151, Tank 101-AZ Waste Retrieval System, HNF-SD-WM-ABU-023, Rev. 1, prepared by Numatec Hanford Corporation for Fluor Daniel Hanford, Inc., Richland, Washington.

Nordquist, E. M., 1997b, Project W-151 Checkout - Testing Report, HNF-SD-W151-TRP-003, Rev. 0, prepared by Numatec Hanford Corporation for Fluor Daniel Hanford, Inc., Richland, Washington.

Nordquist, E. M., 1997c, Project W-151 Project Field Verification Documentation, HNF-SD-W151-FVP-001, Rev. 0, prepared by Numatec Hanford Corporation for Fluor Daniel Hanford, Inc., Richland, Washington.

Nordquist, E. M., 1997d, Tank 101-AZ Waste Retrieval System Functional Design Criteria, HNF-SD-W151-FDC-001, Rev. 4, prepared by Numatec Hanford Corporation for Fluor Daniel Hanford, Inc., Richland, Washington.

Nordquist, E. M., 1997e, Cathodic Protection Acceptance Test Procedure, HNF-SD-W151-ATP-002, Rev. 1, prepared by Numatec Hanford Corporation for. Fluor Daniel Hanford, Inc., Richland, Washington. 


\section{HNF-1901 Rev 1}

\section{Documents}

Orme, R. M., 1999a, Waste Feed Delivery Technical Basis, Volume II, Addendum 2-1, "Waste Feed Delivery Flowsheet for 241-AN-105," HNF-1939, 0b, prepared by Numatec Hanford Corporation for Fluor Daniel Hanford, Inc., Richland, Washington.

Orme, R. M., 1999b, Waste Feed Delivery Technical Basis, Volume II, Addendum 1-1, "Waste Feed Delivery Flowsheet for 241-AZ-101," HNF-1939, Rev. 0a, prepared by Numatec Hanford Corporation for Fluor Daniel Hanford, Inc., Richland, Washington.

Orme, R. M., 1999c, Waste Feed Delivery Technical Basis, Volume II, Addendum 3-1, "Waste Feed Delivery Flowsheet for 241-AN-104," HNF-1939, Rev. Oc, prepared by Numatec Hanford Corporation for Fluor Daniel Hanford, Inc., Richland, Washington.

Papp, I. G., 1998, Waste Feed Delivery System Phase I Baseline RAM Assessment July 1998, HNF-2863, Rev. 0, prepared by Numatec Hanford Corporation for Fluor Daniel Hanford, Inc., Richland, Washington.

Papp, I. G., R. D. Potter, and R. L. Treat, 1998, Waste Feed Delivery Environmental Permits and Approvals Plan, HNF-2401, prepared by Numatec Hanford Corporation for Fluor Daniel Hanford, Inc., Richland, Washington.

Parazin, R. J., 1996a, Phase 1 Privatization Raw and Potable Water Design Requirements Document, WHC-SD-WM-DRD-015, Rev. 0, Westinghouse Hanford Company, Richland, Washington.

Parazin, R. J., 1996b, TWRS Phase 1 Privatization Liquid Effluent Transfer and Roads Design Requirements Document, WHC-SD-WM-DRD-014, Rev. 0, Westinghouse Hanford Company, Richland, Washington.

Parazin, R. J., 1996c, TWRS Privatization Phase 1, Master Site Plan, WHC-SD-TWR-DSD-001, Rev. 0, Westinghouse Hanford Company, Richland, Washington.

Peck, L.G., 1999, River Protection Project Systems Engineering Management Plan, HNF-SD-WM-SEMP-002, Rev. 2, prepared by Lockheed Martin Hanford Corporation for Fluor Daniel Hanford, Inc., Richland, Washington.

Pickett, W. W., 1998, Conceptual Design Report, Immobilized Low-Activity Waste Interim Storage Facility (Phase 1) Project W-465, HNF-1975, Rev. 1, prepared by Fluor Daniel Northwest, Inc., for Fluor Daniel Hanford, Inc., Richland, Washington.

Rasmussen, J. E., 1997, Radioactive Air Emissions Notice of Construction (NOC) Project W-314, Tank Farm Restoration and Safe Operations, (letter 9761603 to A. W. Conklin, Washington State Department of Health and J. Leitch, U.S. Environmental Protection Agency, December 8) U.S. Department of Energy, Richland Operations Office, Richland, Washington. 


\begin{tabular}{|c|}
\hline $\begin{array}{l}\text { Rasmussen, O. R., 1999, Waste Feed.Delivery Technical Basis, Volume III, "Waste Feed } \\
\text { Delivery System Description," HNF-1939, Rev. OA, prepared by Numatec Hanford } \\
\text { Corporation for Fluor Daniel Hanford, Inc., Richland, Washington. }\end{array}$ \\
\hline $\begin{array}{l}\text { Reep, I. E., 1992, Conceptual Design Report Replacement of the Cross-Site Transfer, } \\
\text { WHC-SD-W058-CDR-001, Rev. 0, Westinghouse Hanford Company, Richland, } \\
\text { Washington. }\end{array}$ \\
\hline $\begin{array}{l}\text { Rieck, C. A., 1994, Conceptual Design Report, Initial Tank Retrieval Systems for Project W-211, } \\
\text { WHC-SD-W211-CDR-001, Westinghouse Hanford Company, Richland, Washington. }\end{array}$ \\
\hline $\begin{array}{l}\text { Rieck, C. A., 1997a, Controlled Volume Metering Pump, Specification W211-AP24-P003, } \\
\text { Rev. 0, prepared by Numatec Hanford Corporation for Fluor Daniel Hanford, Inc., } \\
\text { Richland, Washington. }\end{array}$ \\
\hline $\begin{array}{l}\text { Rieck, C. A., 1997b, Diluent/Flush Pump, Specification W211-AP24-P005, Rev. 0, prepared by } \\
\text { Numatec Hanford Corporation for Fluor Daniel Hanford, Inc., Richland, Washington. }\end{array}$ \\
\hline $\begin{array}{l}\text { Rieck, C. A., 1997c, Functional Design Criteria, Project W-211, Initial Tank Retrieval Systems, } \\
\text { HNF-SD-W211-FDC-001, Rev. 3, prepared by Numatec Hanford Corporation for } \\
\text { Fluor Daniel Hanford, Inc., Richland, Washington. }\end{array}$ \\
\hline $\begin{array}{l}\text { Rieck, C. A., 1997d, Mobile Water Heater/Boiler Package, Specification W211-AP24-P002, } \\
\text { Rev. 0, prepared by Numatec Hanford Corporation for Fluor Daniel Hanford, Inc., } \\
\text { Richland, Washington. }\end{array}$ \\
\hline $\begin{array}{l}\text { Rieck, C. A., 1997e, Steel Storage Tanks, Specification W211-AP24-P004, Rev. 0, prepared by } \\
\text { Numatec Hanford Corporation for Fluor Daniel Hanford, Inc., Richland, Washington. }\end{array}$ \\
\hline $\begin{array}{l}\text { Rieck, C. A., 1998, Safety Assessment for Initial Tank Retrieval Systems-Project W-211, } \\
\text { Specification HNF-SD-W211-PSAD-001, Rev. 0, prepared by Numatec Hanford } \\
\text { Corporation for Fluor Daniel Hanford, Inc., Richland, Washington. }\end{array}$ \\
\hline $\begin{array}{l}\text { Rieck, C. A., and M. E. McKinney, 1996a, Retrieval Control System Enclosures, Specification } \\
\text { W211-P003, Rev. 0, prepared by Numatec Hanford Corporation for Fluor Daniel } \\
\text { Hanford, Inc., Richland, Washington. }\end{array}$ \\
\hline $\begin{array}{l}\text { Rieck, C. A., and M. E. McKinney, 1996b, Waste Mobilization Mixer Pump, Specification } \\
\text { W211-P005, Rev. 0, prepared by Numatec Hanford Corporation for Fluor Daniel } \\
\text { Hanford, Inc., Richland, Washington. }\end{array}$ \\
\hline $\begin{array}{l}\text { Rieck, C. A., and M. E. McKinney, 1997, Procurement Specification, Slurry Transfer Pump, } \\
\text { Specification W211-P001, Rev. 1, prepared by Numatec Hanford Corporation for } \\
\text { Fluor Daniel Hanford, Inc., Richland, Washington. }\end{array}$ \\
\hline
\end{tabular}




\section{Documents}

Rifaey, S. H., 1998, Tank Waste Remediation System Engineering Plan, HNF-1947, Rev. 0, DRAFT, prepared by Lockheed Martin Hanford Corporation for Fluor Daniel Hanford, Inc., Richland, Washington.

RL, 1991a, Dangerous Waste Part B Permit Application for the 222-S Laboratory Complex, DOE/RL 91-27, Rev. 0, U.S. Department of Energy, Richland Operations Office, Richland, Washington.

RL, 1991b, Hanford Central Waste Complex - Radioactive Mixed Waste Storage Facility Dangerous Waste Permit Application, Volumes I and II, DOE/RL 91-17, Rev. 0, U.S. Department of Energy, Richland Operations Office, Richland, Washington.

RL, 1996a, Hanford Strategic Plan, DOE/RL 96-92, Rev. 0, U.S. Department of Energy, Richland Operations Office, Richland, Washington.

RL, 1996b, Project Hanford Management Contract (PHMC), DE-AC06-96RL13200, U.S. Department of Energy, Richland Operations Office, Richland, Washington.

RL, 1996c, Recommendation 93-5 Implementation Plan, DOE/RL 94-0001, Rev. 1, U.S. Department of Energy, Richland Operations Office, Richland, Washington.

RL, 1997a, Hanford Facility Dangerous Waste Permit Application, 242-A Evaporator, DOE/RL 90-42, Rev. 1, Richland Operations Office, Richland, Washington.

RL, 1997b, Hanford Facility Dangerous Waste Permit Application, Liquid Effluent Retention Facility and 200 Area Effluent Treatment Facility, DOE/RL 97-03, Rev. 0, U.S. Department of Energy, Richland Operations Office, Richland, Washington.

RL, 1998, TWRS Privatization Contract, DE-AC06-96RL13308, U.S. Department of Energy, Richland Operations Office, Richland, Washington.

RL, 1999, Hanford Facility Dangerous Waste Part A Permit Application, DOE/RL-88-21, Rev. 3, U.S. Department of Energy, Richland Operations Office, Richland, Washington.

Schreiber, R. D., 1997, Fiscal Year 1997 Memorandum of Understanding for the TWRS Characterization Project, HNF-SD-SM-SD-023, Rev. 0, prepared by Lockheed Martin Hanford Corporation for Fluor Daniel Hanford, Inc., Richland, Washington.

Sederburg, J. P. 1996, Solid Waste Program Technical Baseline Description, WHC-SD-WM-RPT-060, Rev. 2, Westinghouse Hanford Company, Richland, Washington.

Sederburg, J. P., 1997, Waste Management Project Technical Baseline Description, HNF-SD-WM-RPT-288, Rev. 0, prepared by Duke Engineering \& Services, Inc. for Fluor Daniel Hanford, Inc., Richland, Washington. 


\section{Documents}

Shade, J. W., 1997, TWRS Phase 1 Privatization Site Environmental Baseline and Characterization Plan, HNF-SD-TWR-EV-001, Rev. 0, prepared by Numatec Hanford Corporation for Fluor Daniel Hanford, Inc., Richland, Washington.

Shade, J. W., K. A. Blanchard, M. D. Freshley, C. T. Kincaid, B. G. Lauzon, M. G. Peipho, K. Rhoads, J. A. Voogd, J. H. Westsik, and G. A. Whyatt, 1994, Performance Assessment of Grouted Double-Shell Tank Waste Disposal at Hanford, WHC-SD-WM-EE-004, Rev. 1, Volume 1 and Volume 2, Westinghouse Hanford Company, Richland, Washington.

Shaw, C. P., 1992, Mixer Pump Study for Project W-151, WHC-SD-WM-ES-195, Rev. 0, Westinghouse Hanford Company, Richland, Washington.

Shord, A. L., 1997, TWRS Privatization Phase 1 Site Development Design Requirements Document, HNF-SD-WM-DRD-013, Rev. 1, prepared by Numatec Hanford Corporation for Fluor Daniel Hanford, Inc., Richland, Washington.

Singh, G., 1996, Design Requirements Document, Design Requirements for the Phase 1 Privatization Facility Electrical Power, WHC-SD-WM-DRD-011, Rev. 0, Westinghouse Hanford Company, Richland, Washington.

Singh, G., 1997a, Conceptual Design Report TWRS Privatization Phase 1 Liquid Effluent Transfer Systems Subproject W-506, HNF-SD-W506-CDR-001, Rev. 0, prepared by Numatec Hanford Corporation for Fluor Daniel Hanford, Inc., Richland, Washington.

Singh, G., 1997b, Conceptual Design Report TWRS Privatization Phase I Raw and Potable Water, Subproject W-504, HNF-SD-W504-CDR-001, Rev. 0, prepared by Numatec Hanford Corporation for Fluor Daniel Hanford, Inc., Richland, Washington.

Singh, G., 1997c, Conceptual Design Report TWRS Privatization Phase 1 Site Development and Roads Subproject W-505, HNF-SD-W505-CDR-001, Rev. 0, prepared by Numatec Hanford Corporation for Fluor Daniel Hanford, Inc., Richland, Washington.

Singh, G., 1997d, Summary Conceptual Design Report, TWRS Privatization Phase 1 Infrastructure Support Project W-519, HNF-SD-W519-CDR-001, Rev. 0, prepared by Numatec Hanford Corporation for Fluor Daniel Hanford, Inc., Richland, Washington.

Singh, G., 1997e, TWRS Privatization Phase I, Electrical Power System, HNF-SD-W503-CDR-001, Rev. 0, prepared by Numatec Hanford Corporation for Fluor Daniel Hanford, Inc., Richland, Washington.

Staehr, T. W., 1999, Mixer Pump Test Plan for Double-Shell Tank AZ-101, HNF-SD-WM-PTP027, Rev. 3, prepared by COGEMA Engineering Corporation for Fluor Daniel Hanford, Inc., Richland, Washington. 


\section{HNF-1901 Rev 1}

\section{Documents}

Stroup, C. R. 1987, HWVP Analytical Hot Cells Time and Motion Study (internal memorandum 65450-87-016 to D. F. Iwatate, Hanford Waste Vitrification Process Design, January 19), Rockwell Hanford Operations, Richland, Washington.

Taylor, W. J., 1997a, "Contract Number DE-AC06-96-RL13200 - Decision Document for the Final Disposition of Cesium and Strontium Capsules, HNF-SD-WM-294, Rev. 0," (letter \# 97-WDD-058A to H. J. Hatch, Fluor Daniel Hanford, Inc., April), U.S. Department of Energy, Richland Operations Office, Richland, Washington.

Taylor, W. J., 1997b, “Contract Number DE-AC06-96-RL13200 - Tank Waste Remediation System (TWRS) Privatization - Hanford Contractors Readiness to Proceed," (letter \# 9757162A to H. J. Hatch, Fluor Daniel Hanford, Inc., August 8), U.S. Department of Energy, Richland Operations Office, Richland, Washington.

Taylor, W. J., 1998, "Contract Number DE-AC06-96-RL13200 - Waste Disposal Division (WDD) Multi-Year Work Plan (MYWP) Update Guidance for Fiscal Year 1999 (FY99)," (letter \# 98-WDD-103 to R. D. Hanson, Fluor Daniel Hanford, Inc., September 21), U.S. Department of Energy, Richland Operations Office, Richland, Washington.

Teynor, T. K., 1996, "Revised Interim Policy on Regulatory Structure for Low-Level Radioactive Waste Management and Disposal," (letter 96-SWT-247 to President, Westinghouse Hanford Company, August), U.S. Department of Energy, Richland Operations Office, Richland, Washington.

Troyer, G. L., 1995, Project W-151 Flexible Receiver Radiation Detector System Acceptance Test Plan, WHC-SD-W151-ATP-001, Rev. 1, Westinghouse Hanford Corporation, Richland, Washington.

Valero, O. J., 1997, Solid Waste Integrated Forecast Technical (SWIFT) Report: FY 1997 to FY 2070, HNF-EP-0918, Rev. 1, prepared by Waste Management Federal Services of Hanford, Inc. for Fluor Daniel Hanford, Inc., Richland, Washington.

Vann, J. M., E. R. Hamm, and R. D. Crisp, 1998, Tank Waste Remediation System Configuration Management Plan, HNF-1900, Rev. 0, prepared by Lockheed Martin Hanford Corporation for Fluor Daniel Hanford, Inc., Richland, Washington.

Wagoner, J. D., 1997, “Contract Number DE-AC06-96-RL13200 - Approval of Tank Waste Remediation System (TWRS) Basis for Interim Operation (BIO) Readiness and Revised Authorization Basis (AB)," (letter \# 9758386A to H. J. Hatch, Fluor Daniel Hanford, Inc., September 11), U.S. Department of Energy, Richland Operations Office, Richland, Washington.

Warnick, T. L., 1997a, Project W-314 241-AN-A Valve Pit Upgrade Acceptance for Beneficial Use, HNF-SD-W314-ABU-002, Rev. 0, prepared by Fluor Daniel Northwest for Fluor Daniel Hanford, Inc., Richland, Washington. 


\section{Documents}

Warnick, T. L., 1997b, Project W-314 AN-B Valve Pit Upgrade Acceptance for Berieficial Use, HNF-SD-W314-ABU-003, Rev. 0, prepared by Fluor Daniel Northwest for Fluor Daniel Hanford, Inc., Richland, Washington.

Warnick, T. L., 1997c, Project W-314 SN-630 Transfer Line AZ-02A to AN-B Acceptance for Beneficial Use, HNF-SD-W314-ABU-004, Rev. 0, prepared by Fluor Daniel Northwest for Fluor Daniel Hanford, Inc., Richland, Washington.

Warnick, T. L., 1997d, Project W-314 AX-B Valve Pit Upgrade Acceptance for Beneficial Use, HNF-SD-W314-ABU-005, Rev. 0, prepared by Fluor Daniel Northwest for Fluor Daniel Hanford, Inc., Richland, Washington.

Warnick, T. L., 1997e, Project W-314 SN-632 Transfer Line AX-B to AZ-02A Acceptance for Beneficial Use, HNF-SD-W314-ABU-006, Rev. 0, prepared by Fluor Daniel Northwest for Fluor Daniel Hanford, Inc., Richland, Washington.

Warnick, T. L., 1997f, Project W-314 AZ-02A Pump Pit Upgrade Acceptance for Beneficial Use, HNF-SD-W314-ABU-007, Rev. 0, prepared by Fluor Daniel Northwest for Fluor Daniel Hanford, Inc., Richland, Washington.

Warnick, T. L., 1997g, Project W-314 SN-634 Transfer Line A-B to AX-B Acceptance for Beneficial Use, HNF-SD-W314-ABU-008, Rev. 0, prepared by Fluor Daniel Northwest for Fluor Daniel Hanford, Inc., Richland, Washington.

Warnick, T. L., 1997h, Project W-314 AB Valve Pit Upgrade Acceptance for Beneficial Use, HNF-SD-W314-ABU-009, Rev. 0, prepared by Fluor Daniel Northwest for Fluor Daniel Hanford, Inc., Richland, Washington.

Warnick, T. L., 1997i, Project W-314 Master Pump Shutdown Upgrade Acceptance for Beneficial Use, HNF-SD-W314-ABU-001, Rev. 0, prepared by Lockheed Martin Hanford Corporation for Fluor Daniel Hanford, Inc., Richland, Washington.

Weaver, L. L. 1997, 222-S Laboratory Interim Safety Basis, HNF-SD-CP-ISB-002, Rev. 2, prepared by Numatec Hanford Corporation for Fluor Daniel Hanford, Inc., Richland, Washington.

Winkleman, W. D., M. R. Adams, T. M. Brown, J. W. Hunt, D. J. McCain, and L. J. Fergestrom, 1997, FY 1997 - 1998 Waste Information Requirements Document,

HNF-SD-WM-PLN-126, Rev. B, prepared by Lockheed Martin Hanford Corporation for Fluor Daniel Hanford, Inc., Richland, Washington.

WMH, 1998, Hanford Site Solid Waste Acceptance Criteria, HNF-EP-0063, Waste Management Federal Services of Hanford, Inc., Richland, Washington. 
HNF-1901 Rev 1

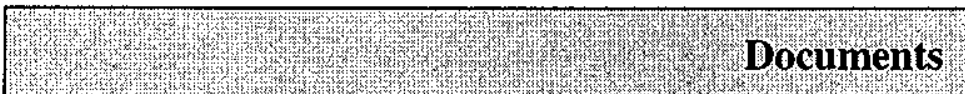

Ziada, A. H., 1994, Stress Analysis of 4- to 6-Inch and 42-Inch Flexible Receiver, WHC-SD-W151-DA-003, Rev. 0, Westinghouse Hanford Company, Richland, Washington.

Ziada, A. H., 1996, W-151 Mixer Pump Energy Absorption Cylinder Analysis, WHC-SD-W151-DA-004, Rev. 0, Westinghouse Hanford Company, Richland, Washington.

Zimmerman, B. D., 1998, Tank Waste Remediation System Risk Management Plan, HNF-SD-WM-PMP-018, Rev. 2, prepared by Lockheed Martin Hanford Corporation for Fluor Daniel Hanford, Inc., Richland, Washington. 
HNF-1901 Rev 1

\section{APPENDIX H}

\section{GUIDANCE AND REQUIREMENTS}

TO DELIVERABLES CROSSWALK

TWRS Retrieval and Disposal Mission Technical Baseline Summary Description 


\section{HNF-1901 Rev 1}

This page intentionally left blank.

H-ii 
Table H-1. Guidance and Requirements to Deliverables Crosswalk - Retrieval and Disposal Mission Technical Baseline Summary Description.

\begin{tabular}{|c|c|c|}
\hline Guidance or Requirement & Status & Implementing Location \\
\hline 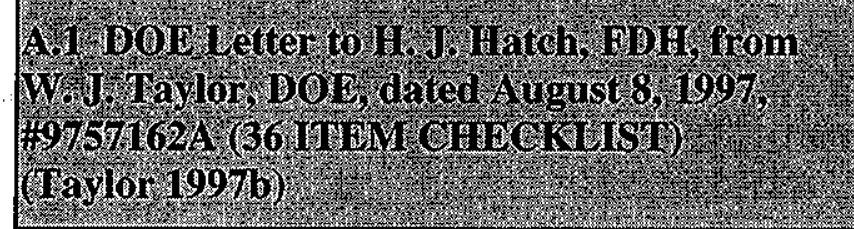 & & (1) \\
\hline $\begin{array}{l}\text { 2. Requirements are identified, validated, and } \\
\text { documented }\end{array}$ & $I$ & Section 2 \\
\hline 3. Requirements are allocated to functions & I & Section 2 \\
\hline $\begin{array}{l}\text { 4. Each activity is tied to and necessary to } \\
\text { support a contractual requirement }\end{array}$ & I & $\begin{array}{l}\text { Section 5, Interface Control } \\
\text { Documents (ICDs); Section 6, } \\
\text { Product Return; Section 7, } \\
\text { Secondary Waste }\end{array}$ \\
\hline $\begin{array}{l}\text { 5. Architecture is defined based upon analyses } \\
\text { of the mission and the functions and } \\
\text { requirements }\end{array}$ & I & $\begin{array}{l}\text { Section } 3.4 \text { (SSCs); Section } 6.4 \\
\text { (SSCs); Section 7; Section } 4\end{array}$ \\
\hline $\begin{array}{l}\text { 8. Operations plans that describe how the } \\
\text { PHMC-Team will execute the technical baseline } \\
\text { have been prepared for all projects and are } \\
\text { supported by lower-tier plans. The operations } \\
\text { plans are consistent with the MYWP and LCAM. } \\
\text { O\&M plans are integrated }\end{array}$ & & $\begin{array}{l}\text { Section } 3.2 \text { (RPP O\&UP); } \\
\text { Section 3.5; Section 6.5.5; } \\
\text { Section 7.6.2 (SWIFT) }\end{array}$ \\
\hline $\begin{array}{l}\text { 9. System boundaries and interfaces with other } \\
\text { organizations and programs/projects are defined }\end{array}$ & I & Sections $3,5,6,7$, and 8 \\
\hline $\begin{array}{l}\text { 13. Immobilized waste product project plans and } \\
\text { implementing actions and procedures are on } \\
\text { track }\end{array}$ & I & Section 6 \\
\hline $\begin{array}{l}\text { 14. Plans and implementing actions that support } \\
\text { privatization contract requirements for dealing } \\
\text { with waste processing plant by-products, } \\
\text { including interfacing with other contractors, are } \\
\text { on track }\end{array}$ & I & Section 7 \\
\hline
\end{tabular}


Table H-1. Guidance and Requirements to Deliverables Crosswalk - Retrieval and Disposal Mission Technical Baseline Summary Description.

\begin{tabular}{|c|c|c|}
\hline Guidance or Requirement & Status & Implementing Location \\
\hline $\begin{array}{l}\text { 16. The technical baseline is complete and } \\
\text { defensible, and represents best value to the } \\
\text { government }\end{array}$ & I & Entire document \\
\hline $\begin{array}{l}\text { 17. The technical baseline is under configuration } \\
\text { control }\end{array}$ & I & Entire document \\
\hline $\begin{array}{l}\text { 19. The physical integrity of existing systems, } \\
\text { structures, and components has been verified }\end{array}$ & $\mathrm{I}$ & Section 3 \\
\hline $\begin{array}{l}\text { 20. Waste has been characterized as necessary to } \\
\text { satisfy all data quality objectives. }\end{array}$ & I & Section 3 \\
\hline $\begin{array}{l}\text { 27. Schedule risk has been identified and is } \\
\text { being managed }\end{array}$ & $\mathrm{I}$ & Sections 3.4.3 and Section 6.4.3 \\
\hline $\begin{array}{l}\text { 32. Environmental permits and safety } \\
\text { authorization bases are in place as required for } \\
\text { authorization-to-proceed decision }\end{array}$ & I & Section 3 \\
\hline 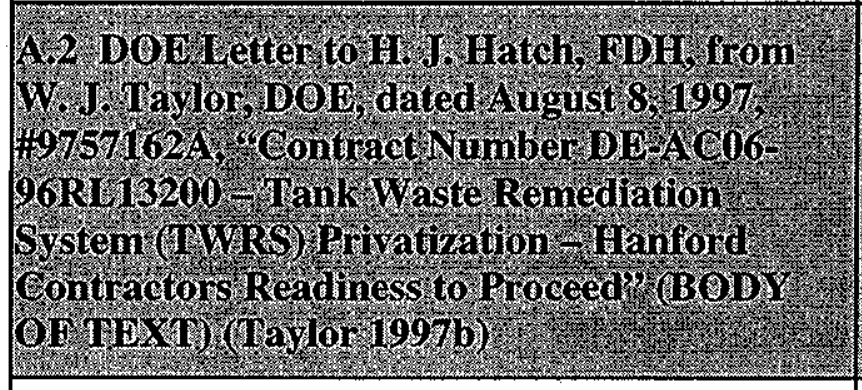 & 3 & 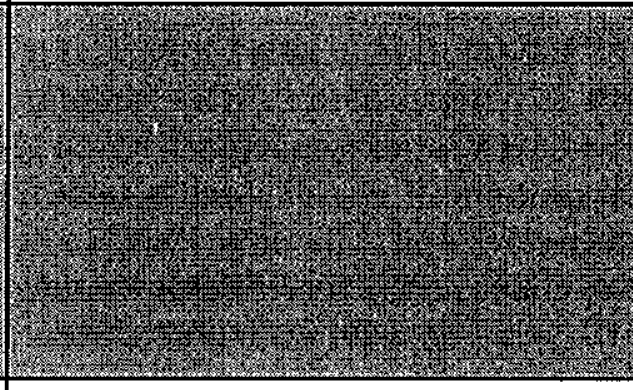 \\
\hline $\begin{array}{l}\text { General PHMC Responsibilities from RL's } \\
\text { 8/8/97 letter, Section } 2.1\end{array}$ & - & \\
\hline $\begin{array}{l}\text { 1. Establish a sound technical baseline, } \\
\text { including approved interface control documents }\end{array}$ & I & $\begin{array}{l}\text { Entire document; Section } 5 \text { includes } \\
\text { the ICDs }\end{array}$ \\
\hline $\begin{array}{l}\text { 3. Work in the technical baseline can be } \\
\text { performed }\end{array}$ & I & Entire document \\
\hline $\begin{array}{l}\text { 5. The technical and programmatic baselines are } \\
\text { under configuration management }\end{array}$ & I & $\begin{array}{l}\text { Entire document; tables demonstrate } \\
\text { items kept current }\end{array}$ \\
\hline
\end{tabular}


Table H-1. Guidance and Requirements to Deliverables Crosswalk - Retrieval and Disposal Mission Technical Baseline Summary Description.

\begin{tabular}{|c|c|c|}
\hline Guidance or Requirement & Status & Implementing Location \\
\hline $\begin{array}{l}\text { Specific Responsibility from RL's August 8, } \\
1997 \text { letter, Section } 2.2\end{array}$ & . & \\
\hline $\begin{array}{l}\text { 1. Waste feed can be provided to the private } \\
\text { contractors in the specified amount to the } \\
\text { specified place at the required time }\end{array}$ & I & Section 3 \\
\hline $\begin{array}{l}\text { 2. Infrastructure support can be provided to the } \\
\text { private vendors as specified in the final } \\
\text { privatization contract and Interface Control } \\
\text { Documents }\end{array}$ & I & Sections 5 and 8 \\
\hline $\begin{array}{l}\text { 3. The PHMC Team will be prepared for } \\
\text { receiving, storing, and disposing of immobilized } \\
\text { waste products }\end{array}$ & I & Section 6 \\
\hline $\begin{array}{l}\text { 4. The PHMC-Team are prepared for receiving, } \\
\text { managing, treating, and disposing of byproducts } \\
\text { from private contractors }\end{array}$ & $I$ & Section 7 \\
\hline 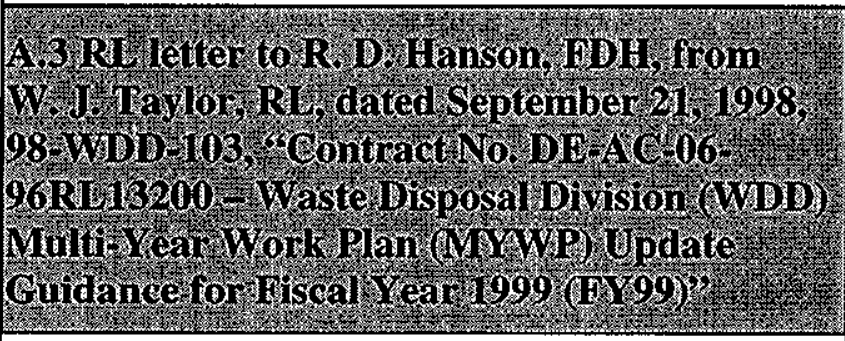 & 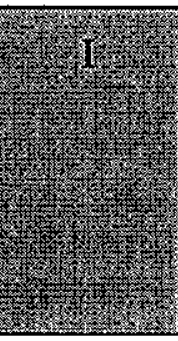 & 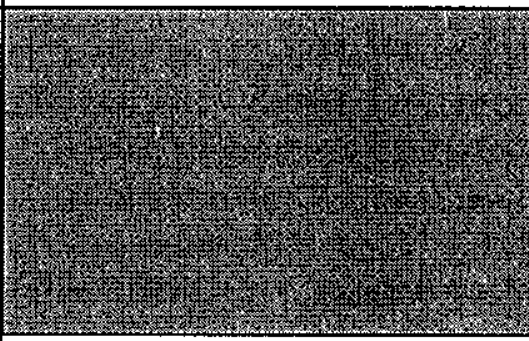 \\
\hline $\begin{array}{l}\text { 5. Section } 2.2 .1 \text {, Paragraph } 6 \text {, Bullet } 6- \\
\text { Organizations will prepare or update plans, } \\
\text { including readiness-to-proceed assessments, that } \\
\text { support the B-2 decision in August } 2000 \text {. DOE } \\
\text { recommendations on the Readiness-To-Proceed } \\
\text { Evidence Package (98-WDD-032) shall be } \\
\text { addressed in the revised documentation }\end{array}$ & $\mathrm{I}$ & \\
\hline
\end{tabular}


Table H-1. Guidance and Requirements to Deliverables Crosswalk - Retrieval and Disposal Mission Technical Baseline Summary Description.

\begin{tabular}{|c|c|c|}
\hline Guidance or Requirement & Status & Implementing Location \\
\hline 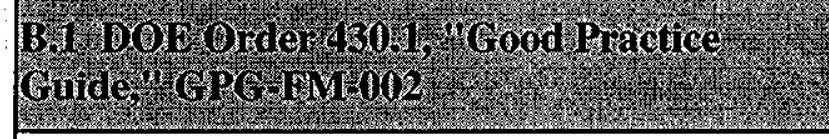 & 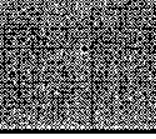 & \\
\hline $\begin{array}{l}\text { 2.3.3 Baseline: Work Scope (Technical) } \\
\text { Criteria }\end{array}$ & I & Section 7 \\
\hline C. Inter ace Control bocuments & 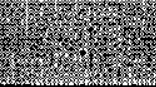 & 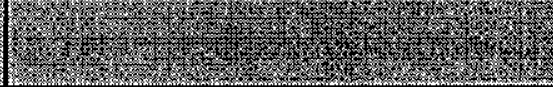 \\
\hline 3. Radioactive Solid Wastes & I & Sections 5 and 7 \\
\hline $\begin{array}{l}\text { 5. Non-Radioactive, Non-Dangerous Liquid } \\
\text { Effluents }\end{array}$ & & \\
\hline $\begin{array}{l}\text { 8. Provide specification by November } 1999 \text { to } \\
\text { BNFL Inc. for interface hardware components } \\
\text { (leak detectors/pump interlocks) }\end{array}$ & & \\
\hline 6. Radioactive, Dangerous Liquid Effluents & & \\
\hline $\begin{array}{l}\text { 4. Compare the predictive effluent } \\
\text { characteristics to the Liquid Effluent Retention } \\
\text { Facility / Effluent Treatment Facility } \\
\text { (LERF/ETF) treatability tests, BNFL Inc. } \\
\text { pretreatment, or LERF/ETF. Process } \\
\text { modifications are necessary }\end{array}$ & I & \\
\hline $\begin{array}{l}\text { 10. Provide specification by August } 1999 \text { to } \\
\text { BNFL Inc. for interface hardware components. }\end{array}$ & I & \\
\hline 7. Non-Dangerous Solid Wastes & - & \\
\hline $\begin{array}{l}\text { 1. Not accept non-radioactive, non-dangerous } \\
\text { solid wastes. }\end{array}$ & I & Section 5 \\
\hline 8. Liquid Sanitary Wastes & . & \\
\hline 1. Not accept liquid sanitary wastes. & I & Section 5 \\
\hline 10. Deactivate Facility and Site & I & Sections 5 and 9 \\
\hline 13. Non-Routine High-Level Solid Wastes & $I$ & $\begin{array}{l}\text { Sections } 5 \text { and } 7 \text { (Central Waste } \\
\text { Complex) }\end{array}$ \\
\hline
\end{tabular}


Table H-1. Guidance and Requirements to Deliverables Crosswalk - Retrieval and Disposal Mission Technical Baseline Summary Description.

\begin{tabular}{|c|c|c|}
\hline Guidance or Requirement & Status & Implementing Location \\
\hline 14. Immobilized High-Level Waste & I & Sections 5 and 6 \\
\hline 15. Immobilized Low-Activity Waste & I & Sections 5 and 6 \\
\hline $\begin{array}{l}\text { 16. }{ }^{90} \text { Strontium/Transuranics/Entrained } \\
\text { Solids }\end{array}$ & $\mathrm{I}$ & Sections 5 and 6 \\
\hline 17. ${ }^{137}$ Cesium & I & Sections 5 and 6 \\
\hline 18. ${ }^{99}$ Technetium & I & Sections 5 and 6 \\
\hline 19. Low-Activity Waste Feed & I & Sections 3 and 5 \\
\hline 20. High-Level Waste Feed & I & Sections 3 and 5 \\
\hline 21. Waste Feed Tanks & I & Sections 4 and 5 \\
\hline 24. Pretreated Low-Activity Waste & I & \\
\hline $\begin{array}{l}\text { D.1 TWRS Waste Disposal Division Planning } \\
\text { Guidance dated Jily } 7,1997 \text { (Godated } \\
\text { December } 12,1997 \text { ) }\end{array}$ & & \\
\hline $\begin{array}{l}\text { Division will prepare integrated plans consistent } \\
\text { with the technical baseline and fully coordinated } \\
\text { across projects }\end{array}$ & I & Section 1.1 \\
\hline PHMC develop sludge washing capability & I & Section 2 \\
\hline $\begin{array}{l}\text { Retrieve and blend double-shell tank (DST) } \\
\text { waste to make room for single-shell tank (SST) } \\
\text { waste }\end{array}$ & I & \\
\hline $\begin{array}{l}\text { Waste Retrieval Project will plan for the } 18 \\
\text { Phase } 1 \text { items in paragraph 3.2.1 }\end{array}$ & I & Section 3 \\
\hline $\begin{array}{l}\text { Waste Retrieval Project will assume the } 11 \text { items } \\
\text { in paragraph 3.2.2 }\end{array}$ & I & Section 3 \\
\hline
\end{tabular}


Table H-1. Guidance and Requirements to Deliverables Crosswalk - Retrieval and Disposal Mission Technical Baseline Summary Description.

\begin{tabular}{|l|c|l|}
\hline \multicolumn{1}{|c|}{ Guidance or Requirement } & Status & Implementing Location \\
\hline $\begin{array}{l}\text { Waste Feed Delivery will define feed process } \\
\text { and retrieval systems, integrate the waste feed } \\
\text { delivery technical baseline, and define Retrieval } \\
\text { Project requirements to interface with Hanford } \\
\text { Tanks Initiative (HTI) and other EM-50 funded } \\
\text { projects }\end{array}$ & I & Section 3.2.1 \\
\hline $\begin{array}{l}\text { Complete low-activity waste (LAW) feed } \\
\text { definition, staging plans, process flowsheets }\end{array}$ & I & Section 3.2.1 \\
\hline $\begin{array}{l}\text { Complete design activities and safety studies to } \\
\text { support the installation of mixer pumps in AP- } \\
102, \text { AP-104 and AN-105 }\end{array}$ & I & Section 3.4.1 \\
\hline $\begin{array}{l}\text { Waste Processing will prepare the 13 plans } \\
\text { outline in paragraph 3.3.2.1 }\end{array}$ & I & Section 3 \\
\hline $\begin{array}{l}\text { Waste Processing will make the Phase 1 } \\
\text { assumptions outlined in paragraph 3.3.2.1 }\end{array}$ & I & Section 3 \\
\hline $\begin{array}{l}\text { Decontaminate and decommission all } \\
\text { infrastructures that provided services to the } \\
\text { Private Contractor and deactivate systems } \\
\text { following decontamination and decommissioning } \\
\text { of the facilities }\end{array}$ & I & Sections 5 and 9 \\
\hline $\begin{array}{l}\text { Immobilized Tank Waste Storage and Disposal } \\
\text { Project will use the items listed in paragraph } \\
\text { 3.4.1 as a basis for planning }\end{array}$ & I & Section 3 \\
\hline $\begin{array}{l}\text { The Storage and Disposal project will ensure that } \\
\text { the requirements in paragraph 3.4.2 are met }\end{array}$ & I & Section 3 \\
\hline $\begin{array}{l}\text { The storage and disposal project is responsible } \\
\text { for the planning assumptions outlined in } \\
\text { paragraph 3.4.3 for IIAW, immobilized high- } \\
\text { level waste (IHLW), and cesium and strontium } \\
\text { capsules }\end{array}$ & I & Section 3.4.3 and Section 5 \\
\hline
\end{tabular}


HNF-1901 Rev 1

Table H-1. Guidance and Requirements to Deliverables Crosswalk - Retrieval and Disposal Mission Technical Baseline Summary Description.

\begin{tabular}{|l|c|l|}
\hline \multicolumn{1}{|c|}{ Guidance or Requirement } & Status & Implementing Location \\
\hline $\begin{array}{l}\text { IHLW Storage will update the statement of work } \\
\text { to prepare the conceptual design for IHLW } \\
\text { storage facilities and issue for review a } \\
\text { conceptual design and preliminary safety } \\
\text { evaluation }\end{array}$ & I & Section 6.2 and Section 5 \\
\hline $\begin{array}{l}\text { Cesium and Strontium Capsules Project will } \\
\text { update the Alternative Generation Analysis and } \\
\text { Decision Analysis Report and the Cesium } \\
\text { Strontium Capsule Disposition Decision } \\
\text { Analysis }\end{array}$ & I & Section 6.2 and Section 5 \\
\hline $\begin{array}{l}\text { Retrieval will follow the special MYWP } \\
\text { requirements outlined in paragraph 4.2 }\end{array}$ & I & Section 6.3 \\
\hline
\end{tabular}


HNF-1901 Rev 1

This page intentionally left blank.

H-8 